
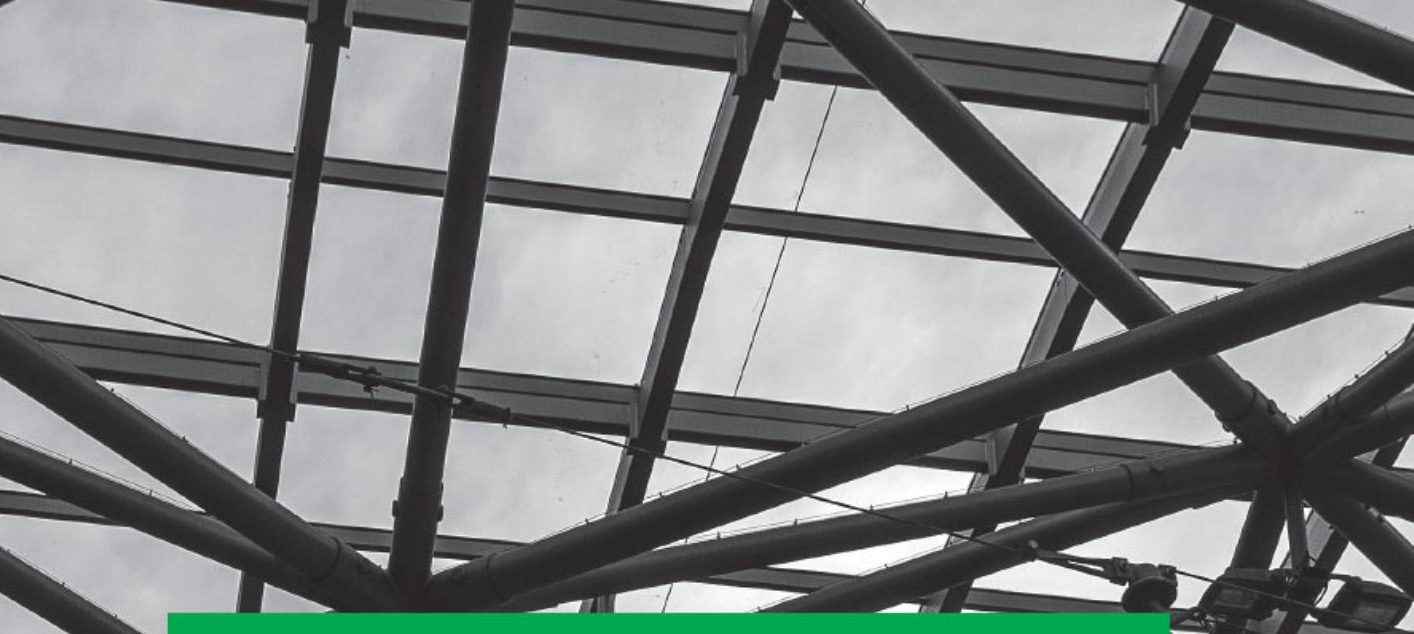

Bēgšana no brīvības?

Erihs Fromms un Latvija
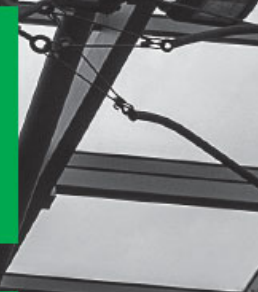

Dr. phil. profesora Igora Šuvajeva zinātniskajā redakcijā
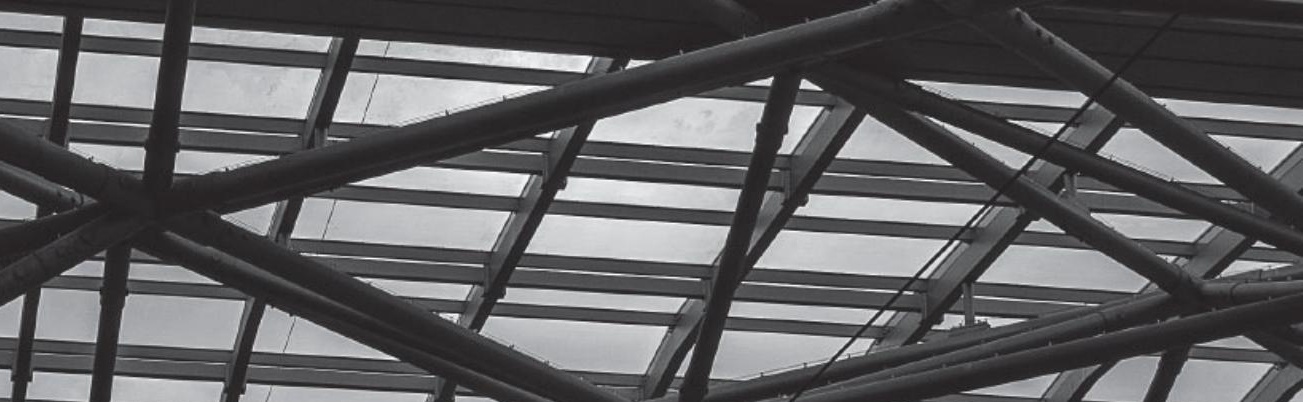

$\sqrt{2}$

$\rightarrow+$

$\rightarrow \infty$

$\sqrt[3]{2}$

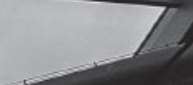

या

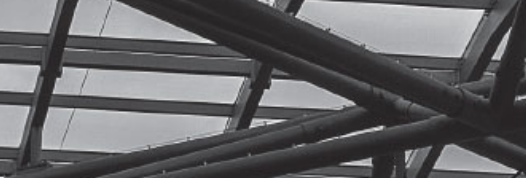

$- 2 \longdiv { 1 2 }$

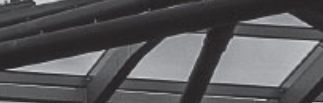

$7 \sqrt{2}$

512

$\longrightarrow$

$2 \approx$

E를

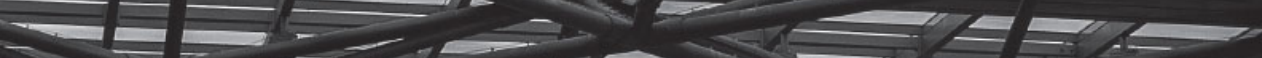

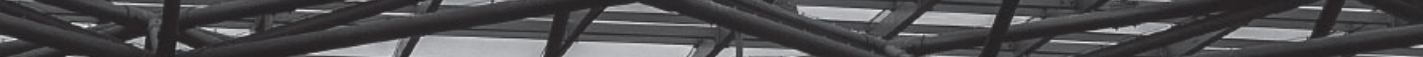

I. -

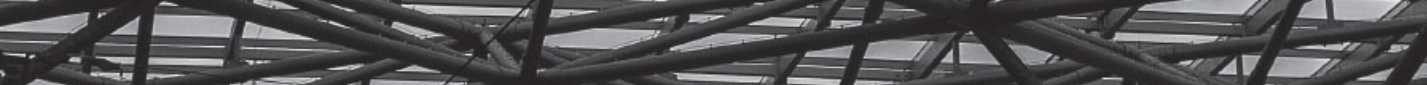

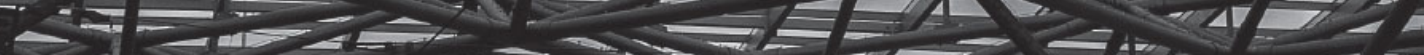

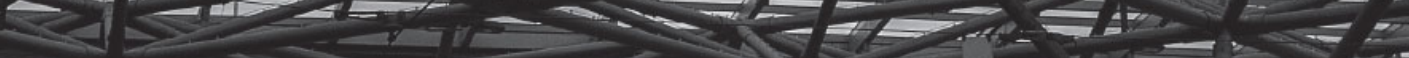


Latvijas Universitātes Filozofijas un socioloǵijas institūts

\section{Bēgšana no brīvības? Ërihs Fromms un Latvija}

Dr. phil. profesora Igora Šuvajeva zinātniskajā redakcijā

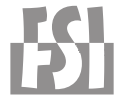

Rīga 2014 

Bēgšana no brīvības?

Ērihs Fromms un Latvija 
UDK $\quad 101 / 104$

Be 138

Bēgšana no brīvības? Ērihs Fromms un Latvija.

Rìga, LU ağentūra „LU Filozofijas un sociologijas institūts”, 2014, 234 lpp.

Escape from Freedom? Erich Fromm and Latvia.

Institute of Philosophy and Sociology, University of Latvia, 2014, 234 p.

Kolektīiā monogrāfija „Bēgšana no brīivibas? Ērihs Fromms un Latvija” sagatavota LZP projekta „Fenomenolog̣iskie pētijumi (saistībā ar S. Kirkegoru, A. Bergsonu un psihoanalīzi)" ietvaros.

Rekomendēts publicēšanai LU aǵentūras LU Filozofijas un sociolog̣ijas institūts Zinātniskās padomes sēdē 20I4. gada 5. novembrī.

Zinātniskais redaktors un sastādītājs Dr. phil. profesors Igors Šuvajevs

Zinātniskie recenzenti:

Latvijas Universitātes Vēstures un filozofijas fakultātes profesore Dr. habil. phil. Māra Rubene

Latvijas Universitātes Vēstures un filozofijas fakultātes docents Dr. phil. Raivis Bičevskis

Literārā redaktore Arta Jāne

Makets un vāka dizains Māris Kūlis

(c) Latvijas Universitātes aǵentūra „LU Filozofijas un socioloǵijas institūts”

(C) Vāka, titullapas un maketa noformējums Māris Kūlis 


\title{
Saturs
}

Igors Šuvajevs

Ievads jeb Fromms un Latvija . . . . . . . . . . . . . . . . ix

FROMMS: DZĪVE UN IDEJAS

Helmuts Johahs

Ērihs Fromms - biogrāfiski idejvēsturisks ievads ........... 3

Rainers Funks

Jautājums par brīvību 70 gadus pēc Ēriha Fromma darba „Bēgšana no brīvības".

\author{
FROMMS UN LATVIJA
}

Maija Kūle

Brīvības problēmas mūsdienu Latvijā Ēriha Fromma analītiskās sociālpsiholog̣ijas kontekstā . 
Solveiga Krūmiņa-Koṇkova

Ėrihs Fromms, Rūdolfs Šteiners un „gara zinātnes”

Latvijā 20. gadsimta sākumā .

Igors Šuvajevs

Ērihs Fromms: brīvība un dzīvesmāksla.

FROMMS PSIHOANALİZES UN FILOSOFIJAS KONTEKSTĀ

leva Stūre-Stūriṇa

Bēgšanas mehānismi un nāves dziṇa:

sadomazohisms un destruktivitāte. $8 \mathrm{I}$

Anne Sauka

'Būt' un 'piederēt' miesiskās patības ètikas kontekstā.

Ainārs Sauka

Cilvēka atsvešināti sociālā un dionīsiskā būšana . . .

Māris Kūlis

Kas ir patiesība? Ēriha Fromma modelis

Anna Kande

Brīvība stoa filosofijas determinismā I3I

Edijs Šauers

Brīvība kā mīlestības vai mīlestība kā brīvības nosacījums:

kopīgais un atšksirīgais I. Kanta un Ė. Fromma

pārdomās par mīlestību un brīvību

147

PIELIKUMS

Ërihs Fromms

Bēgšana no brīvības.

Igors Šuvajevs

Noslēgums jeb Fromma aktualitāte Latvijā . 
Fromma dzivesgājums........................ 203

Fromma darbu hronologiskais saraksts . . . . . . . . . . . . . 207

Erich Fromm and Latvia. Summary. . . . . . . . . . . . . 217 



\section{Igors Šuvajevs}

\section{levads jeb Fromms un Latvija}

Šìs kolektīiās monogrāfijas aizsākumi ir rodami 2013. gadā, kad Rīgā notika starptautiska konference „Brīiiba un brīiibas: iespējas un draudi”. Tā notika sadarbībā ar starptautisko Ēriha Fromma biedrību, tajā piedalijāās psihoanalīitịi, filosofi, psihoterapeiti un psihologi no Vācijas, Meksikas un Latvijas. Neatsveramu ieguldijjumu šajā konferencē sniedza Rainers Funks², kādreizējais Fromma zinātniskais sekretārs un tagadējais viņa autortiesību pārvaldìtājs. Savukārt konferences patronese bija Latvijas eksprezidente Vaira Vỉķe-Freiberga, kura dalijāas savos pieredzējumos saistībā ar Frommu. Tā arī nobrieda ideja par kolektīvo monogrāfiju. Uzreiz visu nav iespējams aptvert, tāpēc šajā darbā uzmanības centrā ir Fromms, kurš skatīts psihoanalīzes, fenomenolog̣ijas (var arī teikt: filosofijas) kontekstā.

Fromma vārds Latvijas publiskajā telpā pirmo reizi acīmredzot figurē 1931. gadā. Iespējams, ka trīsdesmitajos gados viņa vārds Latvijā nav pilnīgi svešs. Piemēram, Daniels Perniks strādā pie darba, par kuru acīmredzot sarakstās ${ }^{3}$ ar Maksu Horkheimeru, kas vada Sociālo pētijumu institūtu, kurā strādā arī Fromms. Taču Fromma klātbūtnei Latvijā nav jābūt arī tiešai, tekstuālai, tā var pastāvēt kā sabalsošanās, vārdā nenosaukta polemika. Tikai jāṇem vērā, ka trīsdesmitajos gados Fromms ir iezīmējis vien dažus savas topošās koncepcijas aspektus. Šajos trīsdesmitajos gados aizsākas arī dziḷais klusums par Frommu. Mazpamazām tas tiek pārvarēts tikai 20. gadsimta septiņdesmito gadu nogalē. Taču pilnā balsī Fromms joprojām nav ierunājies, tāpēc šì kolektīvā monogrāfija ir tikai pirmā iecerētā publikācija. Tai 
vajadzētu sekot citām. Tomēr nav arī ilūziju - šì monogrāfija (vismaz kādu noteiktu laiku) var palikt pēdējā.

Izklāstīt ievadā Fromma koncepciju nav īpaši lielas jēgas, ar to (vismaz ar dažiem koncepcijas aspektiem) iepazīstina šī kolektīvā monogrāfija. Var norādīt uz grāmatas uzbūvi, kas var atvieglināt tās lasī̌sanu. Formāli monogrāfijā ir piecas sadaḷas. Pirmā sadaḷa ir veltīta Fromma dzīvei un idejām. Otrajā sadaḷā Fromms tiek skatīts Latvijas kontekstā, savukārt trešajā - psihoanalīzes un filosofijas kontekstā. Ceturtajā sadaḷā ir ievietots Fromma teksta „Bēgšana no brīvības" tulkojums. Noslēdzošajā daḷā ir aprādīts Fromma dzīvesgājums un publikācijas, kā arī institūcijas, kur meklējami vēl nepublicētie darbi.

Helmuts Johahs pievēršas iepazīstināšanai ar Frommu biogrāfiski idejvēsturiskā aspektā. Viņš raksta par Fromma ǵimeni, izglìtību, jūdaisma ietekmi. Fromms piedzimst ortodoksālā jūdaisma piekritēju ğimenē, taču pašam vēlāk svarīga ir hasīdisma un pravietisma tradīcija. Johahs raksta par Fromma sastapšanos ar psihoanalīzi un novēršanos no ortodoksalitātes, par viņa darbu Sociālo pētỉjumu institūtā, kurā sakņojas arī Fromma uzskata marksistiskie toṇi. Fromms ir spiests atstāt Vāciju, viņš pārceḷas uz ASV. Johahs raksta gan par Fromma dzīves peripetijām (ASV un Meksikā), gan par viņa psihoanalīzes pakāpenisko izstrādi. Noslēgumā Johahs aplūko Fromma dzīves nogali Šveicē un pēdējos darbus. Savukārt Rainers Funks pievēršas Fromma idejām, īpaši uzsverot viņa darbu „Bēgšana no brīvības” (194I) un tā tagadējo aktualitāti. Funks īsumā ieskicē jautājumu par brīvību Vakarzemes (Rietumu) kultūrā un pievēršas Fromma brīvības psihologijai. Viņš uzsver, ka Fromms ir pirmais psihologs, kas pievēršas modernā cilvēka brīivibas problemātikas analīzei. Funks aplūko bailes no brīivibas un jaunlaiku individualizēšanās rezultātus. Îpašu vērību viņš velta tagadnes brīvības jautājumam un raksta par brīivibu kā atbrīvošanos, atrobežošanos, Es-orientētas sabiedrības raksturu. Savas pārdomas Funks noslēdz ar norādi uz mūsdienās pastāvošo neierobežoto brīvību un bailēm no realitātes.

Maija Kūle raksta par brīvību mūsdienu Latvijā Fromma analīiskās sociālpsihologijas kontekstā, neatstājot novārtā paša pēdējā laika notikumus. M. Kūle aplūko brīvību kā vērtību un tās meklējumus, apliecinājumus Latvijā. Viņa parāda gan kopīgo, gan atšķirīgo Fromma un Latvijas intelektuālajos, garīgajos meklējumos. M. Kūle neatstāj neievērotu reliğisko atmodu Latvijā un raksta par liriskām un sadomazohistiskām personībām brīvības kontekstā. 
Viņas pārdomu lokā ir arī tas, kā runā un domā par brīvību, kā funkcionē valoda kā izdzīvošanas stratēgeija. Solveiga Krūmiņa-Koņkova pievēršas mazpētītam tematam, proti, Frommam un Rūdolfam Šteineram un tam, kā tas atbalsojas un izskan Latvijā. Arī S. Krūmiņa-Koņkova norāda, ka Frommu un Šteineru vieno jautājums par brīvību. Îpaši viņa aplūko Šteinera ietekmē topošo gara zinātni Latvijā, celdama gaismā daudzus arhīvu materiālus un aprādot pašmāju antroposofijas un kosmosofijas aprises. Savukārt Igors Šuvajevs mẹgina skatīt Fromma atziṇu pamatotību Latvijas kontekstā. Šajā saistībā viņš izškir tādus fenomenus kā brīvība, brīvības un atbrīvošanās. I. Šuvajevs uzrāda Latvijā noturīgus Fromma aprakstītos mehānismus, kā bēg no brīvības. Šuvajevs skata attiecīgo diskursīvu prakšu elementus un izpausmes jomas. Noslēgumā viņš pievēršas Fromma dzīvesmākslai jeb dzīvotmākslai.

Ieva Stūre-Stūriņa aplūko bēgšanas mehānismus un nāves dziṇu, īpašu uzmanību veltot sadomazohismam un destruktivitātei. Viṇa salīdzina Fromma veikumu ar Freida izstrādnēm, parādot kā kopīgo, tā atškirīgo. Anne Sauka Fromma atziṇas par 'būt' un 'piederēt' skata miesiskās patības ētikas kontekstā. Viṇa gan norāda uz Fromma humānisma iekšējo pretrunīgumu, gan piedāvā citādu viņa lasījumu, kas sakņojas miesas fenomenologiijā saistībā ar miesisko patību. Anne Sauka radikalizē lasījumu, skatot Frommu saistībā ar nihilismu un norādot uz trim miesiskās patības aspektiem: miesas nepieciešamo klātesamību, 'ķermen,a' iluzoritāti un miesas būtisko ētiskumu. Noslēgumā Fromma risinājums tiek aplūkots filosofiskās dzīvesmākslas kontekstā. Savukārt Ainārs Sauka Frommu skata saistībā ar Nīči. Tiek aplūkota atsvešināti sociālā būšana, būšana sociāli noteiktā filtrā, kam tiek pretstatīta būšana dionīsiskā stāvoklī. Viņš aplūko un norāda kā uz kopīgo, tā atšḳirīgo abu domātāju formulējumos.

Māris Kūlis aplūko jautājumu par patiesību. Šā jautājuma skaidrošanai viņš pievēršas Paulam Dālem un Konstantīnam Raudivem, kuriem tad pievieno Frommu. M. Kūḷa skatījumā Fromms izstrādā optimālās patiesības konceptu, kurā saskatāmas līdzības ar pragmatismu. Viņš norāda, ka Fromma būtiskais pienesums ir spriedumi par cilvēka lomu patiesībā, kuri atklājas ikdienas dzīves jautājumu risināšanā. Anna Kande Fromma idejas skata stoa filosofijas kontekstā, īpaši uzsverot determinisma problemātiku, proti, brīvības iespējamību determinisma apstākḷ os. Kandes risinājums tiek 
īstenots dzīvesmākslas filosofijas perspektīvā, skatot tādus jēdzienus kā izvēle, griba un pašvara. Viņa norāda uz stoa filosofijā raksturīgo sevis atgūšanas stratēgiju, savukārt Fromma risinājumu saskata mīlestībā, kurā iekḷaujas arī pašmīlestība. Savukārt Edijs Šauers savieto Frommu un Kantu, parādot abu kopējo ievirzi brīvības un mīlestības izpratnē, neatstājot neievērotu arī atšķirīgo. Tāpēc tiek aplūkotas abu domātāju saskarsmes tēmas: cita cilvēka objektivitāte un atbrīvošanās no narcisma, recionālā ticība, kā arī pašizziṇa un jūtīgums pret sevi.

Kolektīvo monogrāfiju noslēdz Fromma darba „Bēgšana no brīvības” pēdējās nodaḷas „Brīvība un demokrātija” tulkojums. Fromms šim savam darbam pievieno arī pielikumu „Cilvēka raksturs un sociālais process”, kura tulkojums arī tiek piedāvāts šajā grāmatā.

Ievada noslēgumā var atgādināt vienu Fromma atziṇu, kas saistīta ar to, ka mūsdienās bieži vien neizlasa visu grāmatu, apmierinās ar tās pārstāstu vai vispār spriež par to bez pašas grāmatas izlasī̌sanas. Fromms šajā saistībā norāda - jo vājāka patība (pats cilvēks), jo lielākas bailes zaudēt sevi, un neḷaušanās (grāmatai, tās lasī̌sanai) to mazina vēl vairāk. Cerams, ka šai grāmatai nenāksies sastapties ar šādiem cilvēkiem.

\section{Vēres}

I Daḷa referātu publicēti izdevumā: Fromm Forum ı8. 2014, S. 5-66. Nenovērtējamu ieguldījumu konferences nodrošināšanā sniedza Antra Balode (Rīgas Gētes institūts), par to vēlos viṇai sirsnīgi pateikties.

2 Sk.: Funks R. Ëriha Fromma aktualitāte. Rīga: FSI, 2014.

3 Sk.: Šuvajevs I. Psihoanalizzes pēdas Latvijā. Rīga: LU Akadēmiskais apgāds, 20I2, 51. lpp. un tālāk. 
Fromms: dzive un idejas 



\section{Helmuts Johahs}

\section{Ėrihs Fromms - biogrāfiski idejvēsturisks ievads}

\section{I. ĢIMENE UN IZGLĪTĪBA - JŪDAISMA IETEKME}

Ērihs Fromms piedzima 1900. gada 23. Martā Frankfurtē pie Mainas kā vienīgais dēls ebreju vecāku ğimenē. Fakts, ka viņš uzauga kā vienīgais bērns bez brāliem un māsām un ka piedzima ǵimenē, kurā, atṣ̌̌irīibā no daudzām „asimilēto” ebreju giimenēm, aizvien vēl bija dzīva jūdaisma tradīcija, spēcīgi ietekmēja viṇa dzìvi. Kā vienīgais bērns viņš īpaši bija pakḷauts savu vecāku garastāvoklim un neirotiskajiem izturēšanās veidiem, bet sabiedriskajā ziṇā vinaam ( $k a ̄$ mēs to vēlāk zinām) bija jācieš no neveiksmìgās ebreju un vāciešn simbiozes, kas vairumam ebreju nacisma laikā beidzās ar šo katastrofu. Tikai dažiem - starp tiem arī Ēriham Frommam - bija tā laime izvairīties no šìs katastrofas, laicīgi aizbēgot uz ārzemēm. Taču šādi es jau pieskaros trīsdesmitajiem gadiem.

Pagājušā gadsimta sākumā ebreji bija aptuveni astoņi procenti no Frankfurtes iedzīvotājiem. Vecāki - tēvs Naftals Fromms (1869-1933) un māte Roza Fromma (dz. Krauze, 1876-1959) - dzìvoja pēc ortodoksālā jūdaisma noteikumiem un bija cieši iesakņoti ebreju kopienā. Abiem senčos bija slaveni rabīni, un arī Ē. Fromma tēvs labprāt būtu gribējis kḷūt rabīns. Viņš laiku pa laikam cieta no tā, ka uzturs sev un ǵimenei vinam bija jānopelna kā vīna tirgotājam. Naudas pelnǐšana viņam vienmēr bija kaut kas nepatīkams, un šajā ziņā viņam arī nebija īpašu panākumu. Viņš bieži stāstijja stāstu 
par Ē. Fromma vecvectēvu, kuram kādā ciematā Vircburgas tuvumā bija neliels veikaliņš un kurš bija sapīcis, ja kāds ieradās iepirkties, jo šādi viņš tika atturēts no Talmūda studēšanas. Tas ietekmēja arī jaunā Ēriha Fromma dzīves izjūtu. Viņš saka par sevi: „Mana dzīves izjūta [..] nebija modernā cilvēka dzīves izjūta, tā bija pirmsmodernā cilvēka dzīves izjūta." (Fromm, I986, S. I24.) Starp citu, tas nozīmē arī to, ka patiesi svarīgās lietas dzìvē nav atkarīgas no naudas, gluži pretēji, dzī̌sanās pēc naudas mums traucē iepazīt to, par ko tiešām ir runa. Šì ievirze rosina Fromma vēlāko kapitālisma kritiku, piemēram, darbā „Piederēt vai būt” (1976a, GA II, S. 372 ff.). Kritisku pamatievirzi pret kapitālismu $\overline{\mathrm{E}}$. Fromms nav pirmām kārtām iesavinājis no Karla Marksa darbu lasīšanas, tā ir ielikta jau viṇa ğimenes vēsturē.

Attiecības starp vecākiem nebija īpaši harmoniskas. Tēvam bija mazvērtỉbas kompleksi, bet Fromma māte Roza bija depresīva. Vinu īstenoto audzināšanu var dēvēt par „narcistiski ien,emošu” (Funk, I983, S. 2I), jo viṇi mēgināja veidot savu dēlu tā, kā viṇi gribēja to vēlēties sev. Viṇā viss bija „labs, kas bija tipiski krauzisks [mātes meitas uzvārds], un viss bija slikts, kas bija no Fromma” (turpat). Māte iegeērba viṇu meitenes kleitās, jo drīzāk bija vēlējusies meitu, un gribēja no viņa iztaisīt slavenu pianistu, taču tas neatbilda viņa spējām. Arī tēvs tā îsti par viņu neinteresējās. Viņš labprātāk arī turpmāk izturētos pret viṇu kā pret mazu bērnu un ìpaši neuzticējās pieaugošajam dēlam. Kad vēlāk Ērihs Fromms studēja Heidelbergā un kārtoja mutvārdu eksāmenu, lai kḷūtu par Dr. phil., ieradās tēvs no Frankfurtes, jo baidījās, ka Fromms juniors nenokārtos eksāmenu un laupīs sev dzīvību. Bet pārbaudi viņš izturēja ar novērtējumu „l,oti labi”.

Svarīga loma Fromma attīstībā bija tēvocim Ludvigam Krauzem, vectēva brālim no mātes puses, kurš pie Frommiem Frankfurtē pavadīja savu dzīves novakari. Viṇš bija pirmais Fromma Talmūda skolotājs, un no viņa Fromms mācìjās interpretēt Bỉbeli. Asiñaini stāsti par to, kā ebreji ieņēma Kanaānas zemi, viṇu atgrūda, taču stāsti par „Ādama un Ievas nepaklausību”, Abrahama cīkstēšanos ar Dievu, lai glābtu Sodomas un Gomoras iedzīvotājus, Jonas sūtīšanu uz Ninīvi un citas Bībeles detaḷas viṇu fascinēja; taču visvairāk viṇu rosināja „praviešu Jesajas, Āmosa, Hozejas raksti un ne tik daudz viṇu brīdinājumu un bojāejas pareǵošanas dēḷ, bet gan pastardienas sludināšanas dēl, kad tautas „pārkals savus zobenus par lemešiem un savus šķēpus par vīnadārza dārznieku nažiem” (Fromm, I962a, GA IX, S. 40). 
Fromms visu mūžu paturēja tiesības kritiski skatīt Bībeli un dažus stāstus, piemēram, par pirmvecāku šksietamo „krišanu grēkā”, neglaudīt pa spalvai. No agrīnā kaldinājuma, kas gūts no Bībeles un Talmūda studijām tēvoča vadībā, kuras viņš vēlāk turpināja pie Zālamana Rabinkova Heidelbergā, pirmām kārtām izriet Fromma universālistiskā humānisma izpratne - pret rasismu un ciltsdomāšanu - un viņa angažētība jautājumā par mieru.

Ebreju Bībeles un Talmūda agrīno studiju konsekvence bija tā, ka Ērihs Fromms pats gribēja kḷūt par Talmūda skolotāju un šajā nolūkā vēlējās doties uz Lietuvu, lai atbilstīgi izskolotos. Taču vecākiem tas šķita pārāk riskanti viṇi labprātāk gribēja paturēt dēlu savā tuvumā, un tā viņš atteicās no šì plāna. Frankfurtē viņš atrada nozīmīgu skolotāju, Bērnes laukuma sinagogas rabīnu Nehemiju Antonu Nobelu (1871-1922), kas bija humānistiski izglītots vīrs, Gētes cien̄itājs un apdāvināts sprediķ̣otājs. Viņš bija sapulcinājis ap sevi jaunus cilvēkus, šajā lokā jūdaiskajā gaisotnē, saskaņā ar Leo Lēventāla pausto, „iejaucās arī filosofija, nedaudz sociālisma, nedaudz psihoanalīzes un nedaudz arī misticisma” (Löwenthal, I980, S. I8). Bez Leo Lèventāla (1900-1993), kurš vēlāk bija starpnieks kontaktam ar „Sociālo pētījumu institūtu”, Fromms šajā lokā iepazinās arī ar Ernstu Simonu (1899-1988). Leo Lēventāls kḷuva slavens kā kritiskās teorijas un literatūrsociologijas līdzdibinātājs, Ernsts Simons - kā reliǵijas filosofs un pedagogs. Ar viņu Fromms visu mūžu saglabāja kontaktu, kaut arī ne vienmēr abiem bija vienādi uzskati.

Pēc abitūrijas eksāmeniem, ko Fromms nokārtoja kara pēdējā - I918. gadā, iesākumā viņš uzsāka jurisprudences studijas Frankfurtes Universitātē. Taču pēc diviem semestriem viņš devās uz Heidelbergas Universitāti, lai pēc nākamiem diviem semestriem parietu uz „tautsaimniecības” studijām, sociologijas specialitāte, par kuru viņš interesējās visvairāk, - tolaik oficiāli vēl nepastāvēja. Viṇa svarīgākais akadēmiskais skolotājs bija Alfrēds Vēbers (I868-1958), slavenā Maksa Vēbera brālis, taču atšķirībā no viņa bija liberāls profesors. A. Vēbers pārstāvēja vēsturiski pamatotu kultūrsociologiju un bija vienīgais neebrejs starp Fromma akadēmiskajiem skolotājiem, kuru viņš augstu vērtēja. Pie viņa Fromms 1922. gadā promovējās ar darbu „Jūdaiskais likums. Par diasporas jūdaisma sociolog̣iju”. Disertācija pirmo reizi tika publicēta 1989. gadā pēc viṇa nāves rakstu izdevumā (Fromm, I922, patlaban: GA XI, S. 19-I26). Disertācijā kḷūst skaidrs, ka Fromms augstu vērtēja pirmāmkārtām hasīdisko jūdaismu. 
Studiju laikā Fromms braukāja starp Heidelbergu un Frankfurti, lai, no vienas puses, nezaudētu kontaktu ar rabīnu Nobelu, bet, no otras puses, - lai izveidotu „Ebreju tautizglītības biedrību”, bet nedaudz vēlāk - „Ebreju brīvo mācībnamu”, „sava veida ebreju tautskolu” (Funk, 1983, S. 33), kam Franca Rozencveiga (ı886-1929) vadībā divdesmitajos gados bija spēcīga iedarbība. Heidelbergā Fromms turpināja savas Talmūda studijas pie Zālamana Baruha Rabinkova (1882-1939). Rabinkovs viṇam sniedza arī svarīgas norādes par disertāciju. Šis mācītais vīrs jaunajam Ėriham Frommam kḷuva nozīmīgs pirmāmkārtām viña personības dẹl, Fromms raksta par viṇu:

„Rabinkovs varbūt ietekmēja manu dzīvi vairāk nekā jebkurš cits cilvēks. Viņa idejas manī vienmēr bija dzīvas, kaut arī citos priekšstatos un jēdzienos. [..] Viņš nekad nemēǵināja mani ietekmēt, pateikt, kas man darāms, nemēgénāja mani skubināt. Vienīgais, ar ko viņš mani ietekmēja, bija viņa piemērs, kaut gan viņš būtu bijis pēdējais, kurš gribētu sniegt piemēru. Viņš caurcaurēm bija pats." (Cit. pēc: Funk, 1999, S. 54.)

Var teikt, ka jūdaiskais garīgums un jūdaiskā humanitāte ir fundējošā un svarīgākā ietekme, kas veidojusi Ērihu Frommu. Šis kaldinājums viņam saglabājās, kaut arī divdesmitajos gados viņš novērsās no rituālā jūdaisma un vēlāk nepievienojais vairs nevienai ebreju apvienībai. Tas, ka tie izpaužas viņa darbos, t.i., viņa vēlākajos rakstos un visā domāšanas veidā ar tiem raksturīgo jēdzieniskumu, ir minēts jau Rainera Funka disertācijā (sk.: Funk, 1978, S. 23 ff.), taču izteikti izstrādāts tas ir tikai pavisam nesen (sk.: Akrap, 20II).

\section{SASTAPŠANĀS AR PSIHOANALĪZI - DARBS SOCIĀLO PẼTİJUMU INSTITŪTĀ}

Kā otra ietekme, kas garīgi veidojusi Frommu un kas pirmāmkārtām bija svarīga profesijas izvēlē, ir minama psihoanalìze. Šo tolaik ,jauno” terapijas veidu Ērihs Fromms iepazina divdesmito gadu sākumā, pateicoties I gadus vecākai Frìdai Reihmanei (1889-1957). Viṇa bija uzaugusi Kēnigsbergā stingrā jūdaiskā tradīcijā, bija tur promovējusies pie Kurta Goldšteina, - pie viena no tolaik vadošā neirologa un psihiatra, un I9ı8. gadā sekoja viņam uz Frankfurti. 1920. gadā viṇa kā asistējošā ārste devās pie J. H. Šulca, autogēnā treniña pamatlicēja, uz privāto klīniku „Weisser Hirsch” [Baltais briedis] Drēzdenē. Tur viṇa saskārās ar psihoanalīzi un izlēma apgūt psihoanalīzes 
kursu, kuru absolvēja 1923. gadā Berlīnē pie Hansa Zahsa. Ērihs Fromms bija iepazinies ar Frīdu Reihmani jau Frankfurtē un dažas reizes viṇu apmeklēja Drēzdenē, lìdz ar to abi nolēma nopirkt māju Heidelbergā un atvērt privāto „Therapeutikum” [Terapijas nams]. Tā kā abi šajā laikā bija vēl l,oti ticīgi jūdaisti, kas turējās pie jūdaismā atzītajiem svētkiem un rituāliem, ieskaitot baušllus par èdieniem, lasijumus un lūgsnas -, tas tika uzlikts par pienākumu arī nama iemītniekiem un apmeklētājiem. Tāpēc , jokupēteri” - tā savās jaunības atminnās izsakās Geršoms Šolems - runāja par „Torapeitikumu” [ Tora + terapija] (Scholem, 1977, S. 197). Tiesa, Šolems piebilst, ka Fromms un viña draugs Lēventāls tur „aizanalizēja prom ortodokso jūdaismu” (turpat).

„Therapeutikum" pastāvēja līdz 1927. gadam. Viens no pirmajiem Frīdas Reihmanes „pacientiem” bija Ėrihs Fromms. No terapeitiskajām attiecībām izbeidojās mîlestības attiecỉbas, ko abi 1926. gada ı6. jūnijā - Fromma vecāku kāzu dienā - legalizēja ar laulības noslēgšanu. Pirms tam viṇi bija sarāvuši attiecības ar rituālo jūdaismu - šajā ziņā Šolemam ir taisnība viņa apgalvojumā. Pilnīgi droši ir arī tas, ka šo attiecību saraušana bija atvedināma no psihoanalīzes apgaismības gara: Freids, kā zināms, atzinās ateismā un reliǵiskos ritus uzskatỉja par uzmācīgām darbībām. Tā kā Fromms neapprecējās pēc jūdaisma ritiem un laulību noslêdza, neesot klāt vecākiem, tad šādi viṇ̌s atbrīvojās no savu vecāku mājas šaurības. Taču ilgstošā aspektā viṇš palika gādīgs dēls, kurš vēlāk lika lietā visus līdzekḷus, lai savu māti, kas līdz 1938. gadam palika Vācijā, vēl laikus paglābtu no nacisma iznīcināšanas mašinērijas. Fromma tēvs nomira 1933. gadā, vinu neskāra nacisma pasākumi. Kara laikā, kad sākās deportācijas, Ërihs Fromms iestājās arī par saviem Vācijā palikušajiem radiniekiem, tiesa, bez panākumiem. Lielā dạıa no viniiem gāja bojā nacisma geto un iznīcināšanas nometnēs (sk.: Funk, 2005).

Neraugoties uz attiecību saraušanu ar rituālo praksi, tomēr Frommam saglabājās dziḷa garīgi humānistiskā saistỉba ar jūdaismu. To apstiprina, starp citu, arī tas, ka viņš, vēlākais kopš 1948. gada, kad noturēja Terry Lectures „Psihoanalīze un reliǵija” (I950a, GA VI, S. 227-292), atkal vairāk uzsvēra religijas pozitīvos aspektus un 1966. gadā publicēja rakstu par ebreju Bïbeli (1966a, GA VI, S. 83-226). Kopā ar rakstu „Psihoanalīze un dzenbudisms” (1960a, GA VI, S. 30I-356) šie darbi apstiprina, ka Fromms strādāja pie tā, lai izstrādātu lielo reliǵiju kopìgo humānistisko kodolu un lai to beidzot saistìtu ar „transterapeitisko” psihoanalīzi (sk.: Fromm 1969, GA XII, S. 68 ff.). Tiesa, 
kristietiskajā tradīcijā viņa reliğijas izpratnē lielāku nozīmi ieguva tikai Meistars Ekharts, ar kuru viņš nodarbojās vecumā.

„Torapeitikuma” laikā Fromms ar visu enerğiju metās tajā, lai iesavinātu psihoanalīzes ,jaunās” atziṇas. Tā kā viņa sieva viṇu tālākajā nevarēja pietiekami labi izglìtot par analīitịi, Fromms vispirms devās uz Minheni, lai turpinātu savu mācību analīzi pie Vilhelma Vitenberga, bet vēlāk - uz Berlīni, lai to pabeigtu pie Hansa Zahsa (I88I-I947), viena no tuvākā Freida piekritēja un „Slepenās komitejas” locekḷa. Zahss stingri turējās pie noteikumiem, ko bija izvirzījis Freids, lai novērstu personiskos sarežğijumus: ilgstošas atturēšanās, taupīgas interpretācijas un galvenais - nekādu personisku jūtu vai intereses zīmes par pacientu vai mācībā esošu analizandu. Frommu tas neapmierināja, jo šādā veidā nevarēja rasties nekādas veicinošās attiecības. 1930. gadā viņš pabeidza psihoanalīzes apguvi un Berlīnē uzsāka pats savu terapeitisko praksi. Vienlaikus viņš akceptēja piedāvājumu no Frankfurtes pievienoties tur jaundibinātajam Sociālo pētījumu institūtam, piedāvājumu Frommam bija nodrošinājis viņa draugs Leo Lēventāls. Periods starp 1928. un 1932. gadu Frommam laikam ir bijis visai stresains, jo viņ̌s bieži bija ceḷā no Berlīnes uz Heidelbergu, vēlāk - Frankfurti. Viņa sieva Frīda pēc „Therapeutikum” izformēšanas palika Heidelbergā un turpināja savu terapeitisko praksi.

Acīmredzot telpiskās distances noteikta un pakāpeniskās atsvešināšanās dēl Ėriha Fromma un Frīdas Frommas-Reihmanes laulība pastāvēja tikai dažus gadus. Viṇi abi izšķ̄īās I93I. gadā, taču saglabāja draudzīgas attiecības. Šķiršanās sekoja tikai ıo gadus vēlāk ASV. Frīda Fromma-Reihmane kḷuva slavena ar savu terapetisko darbu Chestnut Lodge, kur ar panākumiem ārstēja psihotiķus; turpretim Zigmunds Freids psihoanalīisko darbu ar psihotikiem pasludināja par grūtu.

E. Fromms beidza savu terapeitisko praksi Berlīnē 1932. gadā un pārtrauca savu līdzdarbību Sociālo pētījumu institūtā, jo gandrīz gadu bija spiests ārstēt savu tuberkulozi Šacalpos pie Davosas (tolaik tuberkulozes terapija lielākoties bija uzturēšanās kalnu gaisā; antibiotikas varēja izmantot tikai vēlāk). Hitleram „sagrābjot varu” 1933. gada janvārī, Fromms atradās Šveicē. I933. gada aprīlī gestapo pārtrauca Sociālo pētījumu institūta darbību „valstsnaidīgo centienu” dēḷ. Katrā ziṇā tā direktors Makss Horkheimers (I895-1973), gudri paredzēdams, jau 1931. gadā Ženēvā bija nodibinājis 
institūta filiāli un nogādājis tur drošībā lielāko daḷu institūta mantības. Ērihs Fromms sākumā varēja aizmanīties uz Ženēvu un i934. gadā kopā ar pārējiem institūta pārstāvjiem doties uz N̦ujorku. Viņam bija salīdzinoši nelielas grūtības izvairīties no Trešā reiha un tā slepkavnieciskajām sekām. Taču arī viṇam emigrācija bija gravējošs iegriezums.

Pirms aplūkojam Fromma līdzdarbību Sociālo pētījumu institūtā, jāpiemin viṇa attiecības ar Berlīnes mācībinstitūtu un diviem citiem psihoanalìtikiem, kurus vinšs iepazina ar Frīdas Frommas-Reihmanes starpniecību, Georgu Grodeku un Šāndoru Ferenci.

Berlīnes institūtu 1908. gadā bija nodibinājis Karls Abrahams, turpmākajā laikā tas aizvien vairāk attīstījās par vadošo psihoanalīzes mācībinstitūtu, kas pakāpeniski pārspēja Freida Vīnes mācībinstitūta rangu. Divdesmito gadu beigās, trīsdesmito gadu sākumā Berlīnē darbojās arī Oto Fenihels, Zīgfrīds Bernfelds, Karena Horneja un Vilhelms Reihs (Vilhelms Reihs gan „oficiāli” neskaitījās institūta mācībspēks, taču pie viṇa [mācību] analīzi izgāja diezgan daudzi terapeiti, jo viņš eksperimentēja ar tolaik neierastām ķermeña terapijas metodēm). Daži Berlīnes institūta locekḷi - tostarp Reihs un Bernfelds - bija partijpolitiski „kreisi” orientēti, kas Freidu êrcināja: viņš gribēja psihoanalīzi noturēt pilnīgi ārpus partijpolitikas. Karenai Hornejai (1885-1952) jau tolaik bija „dumpinieces” slava, jo viņa nebija vienisprātis ar Freida sievietes seksualitātes izpratni un viṇa patriarhālajiem aizspriedumiem kopumā. Ērihs Fromms Berlīnē kontaktējās ar psihoanalītiķu „kreiso” spārnu, t.i., diskutēja ar viņiem, taču atturējās no partijpolitiskās aktivitātes. Ar Karenu Horneju viṇam izveidojās draudzīgas attiecības, kas vēlāk ASV kḷuva intensīvākas. Kad viṇa jau 1932. gadā bija devusies uz Čikāgu, viṇa ielūdza Frommu i933. gadā uz vieslekcijām ASV.

Lìdztekus Vīnes un Berlīnes mācībinstitūtiem kopš 1929. gada Karla Landauera vadībā Frankfurtē pastāvēja Dienvidvācu psihoanalīzes institūts, kuram Ērihs Fromms bija līdzdibinātājs. Šì institūta līdzstrādnieki kontaktējās ar Georgu Grodeku (1866-1934), kas ar savu personu un savām nekonvencionālajām terapijas metodēm l,oti ietekmēja Ērihu Frommu. Grodeks gan sevi dēvēja par Freida „skolnieku”, taču piln̄̄gi neatkarīgi no viņa bija izstrādājis sava veida „psihosomatisko” ārstēšanu, kas aizsākās ar k,ermeṇa simptomiem un psihoanalītiskās interpretācijas attiecināja uz „visu” cilvēku. Grodeka sanatorijā Fromms iepazinās arī ar Šāndoru Ferenci (1873-1933), kas 
to regulāri apmeklēja, lai psihosomatiski „ārstētos”. Ferenci bija kreatīvākais starp Freida skolniekiem, viņš iestājās par aktīvāku psihoanalīitịa lomu nekā Freids to uzskatijja par piemērotu. Ferenci izrādīja lielāku personisko interesi par pacientiem un ieklāava savas jūtas attiecībās, proti, tieši to, kas Frommam pietrūka viņa „ortodoksālajā” mācību analītikị. Kaut arī Fromms neizgāja dziedināšanas kursu nedz pie Grodeka, nedz pie Ferenci, viņš l, loti augstu vērtēja abus un izmantoja vingu uzskatus par terapeita lomu, lai pats savu terapeitisko praksi, kad zināmu laiku bija strādājis saskaṇā ar „ortodoksālo” metodi, pakāpeniski pārveidotu „humānistiskā” nozīmē. Tas gan noveda pie nesaskaņām ar toreizējo Sociālo pētījumu institūta „šefu” Maksu Horkheimeru un pārējiem kolēgiem, arī ar Leo Lēventālu.

Sociālo pētījumu institūta gados (1930-1939) Fromms recipiēja daudz ko no tā, ar ko tur sastapās. Taču viņš izstrādāja arī savus konceptus un ar tiem izšķirīgi iesaistìjās institūta darbā. Lìdztekus jūdaismam un psihoanalīzei kā trešais nozīmīgais lielums Fromma gadījumā ir marksisms. Tolaik Fromms to recipiēja vēsturiskā materiālisma formā jeb, kā mēdza izteikties Horkheimers, „ekonomiskajā vēstures uzskatā” (Horkheimer, I932, S. 55). Tas zināmā mērā bija pamatteorija institūta darbā, pēc kuras orientējās atsevišķi nodaḷu vadītāji un līdzstrādnieki (ekonomisti, juristi, filosofi, literatūrzinātnieki u.c.). Par psiholoǵijas jomu bija atbildīgs Fromms. Viņš institūtam sniedza fundējošus teorētiskos darbus un aptauju aptverošai strādnieku un ierēdṇu empīriskai izpētei.

Fromms tolaik Horkheimeram bija „vienīgais teorētiski rosinošais” un „ilgstoši teorētiski vissvarīgākais” institūta līdzstrādnieks (Wigershaus, I986, S. 179, 304). Viṇš aizstāja sava doktordarba vadītāja Alfrēda Vēbera kultūras un sabiedrības teoriju ar vēsturisko materiālismu un tiecās pēc psihoanalīzes un marksisma sintēzes. Viṇa patstāvīgais rezultāts bija analītiskà sociālpsiholoğija, kuras pamatiezīmes Fromms ieskicēja jau pirmajā institūta izdevuma "Zeitschrift für Sozialforschung” numurā. Tur vin,š runā par „raksturu” un „libidozo struktūru”, kas esot „produkts sociālekonomisko apstākḷu iedarbei uz dziṇu tendencēm” (Fromm, 1932a, GA, S. 56), un izstrādā - vēl skaidri to neizsakot un izmantojot „ortodokso" freidisko terminologiju - savu galveno „sabiedrïbas rakstura” konceptu (Fromm, I94Ia, GA I, S. 379 ff.). Strādnieku un ierēdṇu izpētē Fromms konstatēja, ka autoritārais, resp., sadomazohistiskais raksturs spēcīgi dominē zemākajās sabiedrības škịirās. Uz 
šo atzinumu viņš atsaucās vēlāk, kad tika risināts jautājums, kāpēc Vācijā tik strauji varēja nostiprināties nacionālsociālisms (turpat, S. 34I).

Nesaskaņas ar Horkheimeru un pārējiem Sociālo pētījumu institūta līdzstrādniekiem radās tad, kad Karenas Hornejas un Harija Sallivena ietekmē Fromms aptuveni no trīsdesmito gadu vidus Freida dziṇu teoriju centās aizstāt ar saistìtības teoriju. Tā ietvēra gravējošu pārmainu psihoanalīzes antropolog̣iskajā dispozīcijā, jo nu rakstura attīstībai noteicošajam vajadzēja būt nevis sākotnēji izolētā indivīda dažādajām libido organizācijas formām, bet gan „dažādajiem veidiem, kādos cilvēks nostiprina attiecības pasaulē” (Fromm, 1947a, GA II, S. 4I). Pārējie institūta līdzstrādnieki, galvenokārt Adorno ietekmē, kurš nevarēja ciest Frommu, neatzina šo maiṇu un pārmeta Frommam, ka šī revīzija vedot pie „,sociologiiskās kritikas vājināšanās un psihoanalīzes sociālās substances mazināšanās" (Marcuse, I969, S. 239). Tam pievienojās nedraudzīgā konfrontācija saistībā ar Fromma atalgojumu un Horkheimera skarbā vairīšanās aizdot naudu Fromma mātes iecel̦ošanai ASV, un beigu beigās tas noveda pie Fromma izstāšanās no Sociālo pētījumu institūta 1939. gadā. Pirms pievēršos Fromma profesionālajām un politiskajām aktivitātēm pēc I940. gada, jāieskatās viṇa šî laika privātās dzīves situācijā.

\section{DZĪVES SITUĀCIJA, PROFESIONĀLĀS UN POLITISKĀS AKTIVITĀTES ASV UN MEKSIKĀ}

Ērihs Fromms bija precējies trīs reizes - visupirms ar Frìdu Reihmani, tad - no 1944. gada - ar Heniju Gurlandi (1900-1952) un pēc viņas agrās nāves - no 1953. gada - ar Enisu Frimani, kura bija divus gadus jaunāka par viņu un nodzīvoja piecus gadus ilgāk par viņu. Pirms Fromma otrās laulības daudzus gadus viņam bija attiecỉbas ar Karenu Horneju, kuru vinšs pazina jau no Berlīnes laika. Karena Horneja bija Is gadus vecāka par viņu. Viņu mīlestības attiecỉbas sarežğỉja tas, ka abus saistīja arī profesionālais darbs. Karenai Hornejai bija medicīniska izglītība, kas bija priekšnoteikums atzīšanai par psihoanalītik,i ASV; Ērihs Fromms bija sociologs, nevis mediķis. Attiecības tika pārtrauktas tad, kad, pamatojoties uz to, ka Fromms nav mediķis, viņam tika liegtas tiesības vadīt klīniskos seminārus (sk.: Funk, 1999, S. I17). Tam pievienojās personiski iemesli: Hornejai skauda Fromma 
panākumi pie studentiem un slava, ko viņš gandrīz vienā mirklī ieguva ar savu pirmo grāmatu „Escape from Freedom” (194I) [Bēgšana no brìvïbas].

Fromma otrajā laulībā šāda konkurence neradās. Henija Gurlande bija pusebrejiete un fotogrāfe; Vācijā viņa strādāja sociāldemokrātiskajai avīzei „Vorwärts”. Trīsdesmitajos gados viña dzīvoja Parīzē un pēc Francijas sakāves viņa ar savu tolaik septin,padsmitgadīgo dēlu Jozefu cauri Spānijai un Portugālei bēga uz N̦ujorku, kur Fromms ar viṇu iepazinās I942. gadā. Literatūrā par vācu ebreju emigrantiem Hennija Gurlande galvenokārt ir pazīstama ar to, ka Valters Benjamins (I892-1940) bija piederīgs bēgḷ grupai, kas pie Portbou Pirenejos gribēja tikt pāri franču robežai. Kad spāṇu robežšķērsošanas ierēdņi liedza iecel̦ošanu, Benjamins ar morfiju darīja sev galu, lai pārējā grupa varētu turpināt ceḷu. Hennija Gurlande noorganizēja Benjamina apbērēšanu, noklusējot viņa suicīdu, un vēlāk darīja zināmu Adorno Benjamina atvadu vēstījumu.

Četrdesmitajos gados Fromms - pēc izstāšanās no Sociālo pētījumu institūta - nodarbojās galvenokārt ar to, lai nostiprinātu savu profesionālo identitāti kā psihoanalītiķis un psihoanalīzes un sociālpsiholog̣ijas docents. Vissvarīgākā pozīcija vin,am bija Nujorkas Washingten School of Psychiatry filiālē, kas 1946. gadā tika pārdēvēta par William Alanson White Institute of Psychiatry, Psychoanalysis and Psychology; šeit viṇš lìdz I950. gadam pārṇēma profesionālās izglītošanas un mācībspēku vadīšanu. Līdztekus tam viñam bija slodze New School for Social Research [Sociālo pētījumu jaunajā skolā] N,ujorkā un profesūra Vermontas Bennington College, apt. 250 kilometri uz ziemeḷiem no N̦ujorkas. Tā kā viṇiem abiem ar Heniju tur l,oti patika, abi 1947./1948. gadā uzbūvēja Benningtonā māju, kurā iemitinājās ar padēlu Jozefu. Taču sakarā ar pienākumiem citviet Fromms varēja tur būt tikai nedẹḷas nogalēs; aktīvās profesionālās darbības laikā tas bija tipiski, ka viṇam nācās daudz ceḷot.

Pēc kāda laiciņa noskaidrojās, ka viņa sieva aizvien vairāk cieš no artrītiskām sāpēm, kas viṇai neḷāva gandrīz kustēties. Ārsti ieteica klimata pārmaiņu saistībā ar radioaktīviem avotiem Meksikā. Fromms reducēja savu mācību darbību, lai nodrošinātu savai sievai ilgstošāku uzturēšanos Meksikā, visbeidzot viņš ar sievu pilnīgi pārcēlās uz Mehiko. Viṇa sievas ciešanas uz laiku izdevās mazināt, bet ne izdziedināt. 1952. gada jūnijā tās darīja galu viñas dzìvei. 
Pēc Hennijas nāves Ērihs Fromms palika Mehiko; viņš tur sabija 23 gadus, no 1950. gada līdz 1973. gadam. Šis laiks - trešā lielā fāze Fromma dzīvē - acīmredzot bija visauglīgākais, jo šeit viņš varēja izvērst kaut ko no tā, kurā tika atzīts par neapstrīdamu autoritāti: aptverošu, arī kultūras apkārtni ietverošu psihoanalìtisko izglìtību, kas saistìta ar sociälpsiholoǵiskiem lauku pētījumiem. Pa šo laiku ar savu iepriekšējo mācību un lekciju darbību ASV un savām grāmatām, piemēram, - „Escape from Freedom” (I94I) un „Man for Himself” [Cilvēks pats sev] (1947) - Fromms bija pierādījis savu terapeitisko kapacitāti. Varēja priecāties, ka vinuu var pierunāt šādam projektam, jo Mehiko, kad viņš tur ieradās, nebija iespējams apgūt psihoanalīzi, bet pieprasījums bija liels. No vairākgadīga izglītības kursa psihiatriem izveidojās Sociedad Psicoanalitica Mexicana. I951. gadā Fromms Mehiko Nacionālās autonomās universitātes Medicīnas fakultātē kḷuva par ārkārtas profesoru, bet no 1963. gada Sociedad rīcībā bija sava institūta ēka, kas bija iekḷauta universitātē.

1953. gadā Ērihs Fromms apprecējās no jauna, šoreiz ar „vistīrāko” amerikānieti no Alabamas, Enisu Frimmani (1902-1985). Viṇa un viņas vīrs Deivids, kurš bija avīzes izdevējs Indijā, ar Frommu bija iepazinušies jau 1948. gadā saistībā ar UNESCO projektu veikt lauku pētījumu Austrālijā (!), taču Hennijas slimības dēḷ Fromms tomēr no tā atteicās (sk.: Funk, 1999, S. 136). Pēc vīra nāves starp Enisu un Ērihu Frommu izveidojās mīlestības attiecības. Nākamā, 23 gadus ilgušā laulība laikam bija loti laimīga, jo sākotnējās maigās attiecības saglabājās visu šo laiku - to apraksta Rainers Funks, ko savām acīm viņš pieredzēja, apmeklējot abus vecumā viņu Lokarno dzīvoklī „Casa la Monda”: piemēram, Ēriham Frommam bija ieradums atstāt sievai maigus vēstījumus uz nelielām lapiņām, kad rītos viņš bija piecēlies, lai sēstos pie rakstāmgalda. Tā, protams, nav nejaušỉba, ka līdz šim panākumiem bagātākā Fromma grāmata "The Art of Loving" [Mäksla mìlèt] (1956), kurā ir runa par divu, be ne tikai divu, attiecībām, tika publicēta dažus gadus pēc viṇa trešās laulības noslēgšanas.

Ērihs Fromms Meksikas laikā Mehiko institūtā nodarbojās ne tikai ar aizvien kuplākas kḷūstošās psihoanalītiķu saimes izglītošanu, viņš uzṇēmās arī mācību pienākumus ASV un noturēja priekšlasījumus par psihologiskām tēmām. Tas bija viņa profesionālais smagumpunkts, kas no viņa - kā „ceḷotāja starp divām pasaulēm” - prasīja daudzus ceḷojumus. Apbrīnojamais un viņa personai raksturīgais bija tas, ka vienlaikus viņš darbojās vēl divās citās 
jomās, kas šķietami ar to nebija saistītas. Viena no tām bija viņa interese par spirituāliem jautājumiem, ar to ir saistìta viņa nodarbošanās ar dzenbudis$m u$, tas ir - seminārs kopā ar Daisecu Sudzuki (sk.: Fromm, 1960a, GA VI, S. 30I-358). Vecumā Fromms meditēja katru dienu un l̦āvās Vācijā dzimuša mūka (Njanaponika Mahathera, dzimis kā Zigmunds Fenigers, 190I-1992) norādēm. Otra joma bija viṇa politiskā angažētība, kas viṇam aukstā kara laikā - līdz ar Mūra būvēšanu Berlīnē un Kubas krīzi - lika iestāties par kodolatbruñǒanos. Ërihs Fromms bija viens no amerikānu miera kustības līdzdibinātājiem; 1962. gadā viņš piedalījās Pasaules miera konferencē Maskavā un ar daudziem memorandiem, kurus izsūtīja politiķiem, mēgināja cīnīties pret to, ka atomkarš tiek iztēlots par nekaitīgu (sk.: Johach, 2000, S. 75 ff.). Vēlīnajos sešdesmitajos gados vin,š nostājās pret Vjetnamas karu un iestājās par Eiženu Makkartiju kā prezidentu, kurš arī bija Vjetnamas kara pretinieks. Darba „The Sane Society” [Veselā sabiedrība], kurā Fromms izklāstīja savus priekšstatus par „komunitāro sociālismu”, ieskaitot „garantēto eksistences minimumu” (Fromm, I955a, GA IV, S. 235 f.), viňš uzrakstīja partijas programmas uzmetumu Savienoto valstu Sociālistiskajai partijai (Fromm,196ob, GA V, S. 19-4I), no kuras gan viņš attālinājās, kad šādā veidā sastapa niecīgu partijas funkcionāru pretmīlestību. Visbeidzot viņš gādāja par Marksa agrīno darbu pārtulkošanu ang̣̦lu valodā un uzrakstīja grāmatu „Marksa koncepcija par cilvēku" (Fromm, 196ıa, GA V, S. 335-393), kas kluva svarīga ASV „Jaunajiem kreisajiem”. Jautājumā par atomstacijām viņš bija saistīts ar tādiem to pretiniekiem kā Bertrānds Rasels un Alberts Šveicers un sociālistiskās nometnes filosofiem Adamu Šaffu un Predragu Vranicki. Viens no viņa draugiem bija Ivans Illihs, „radikāls” katoḷu priesteris. Fromms pat mēgināja iesaistīt pāvestu (!) starptautiskas konferences organizēšanā, kurā pazīstamas personības no visas pasaules izstrādātu ,risinājumus, n,emot vērā cilvēces izdzīvošanas tagadējās briesmas” (Funk, 1999, S. I48), taču toreizējais pavēsts Pāvils VI neiesaistījās.

\section{DZİVES NOVAKARE ŠVEICĒ UN NOSLĒGUMS}

65 gadu vecumā Ērihs Fromms emeritējās meksikāṇu universitātē un cerēja, ka nu, brīvs no mācīšanas pienākumiem, vairāk laika varēs veltīt saviem zinātniskajiem darbiem. Viņšs plānoja četrsējumu darbu par psihoanalīzes 
pamatjautājumiem, no kuriem spēja izstrādāt tikai vienu sējumu, agresijas teoriju - „The Anatomy of Human Destructiveness" [Cilvēka destruktivitātes anatomija] (1973a, GA VII). Visinstruktīvākais, manā ieskatā, šajā grāmatā ir pēdējā nodaḷa „Ādolfs Hitlers, nekrofilijas klīniskais gadījums” (Fromm, 1973a, GA VII, S. 335-393), ar kuru Ērihs Fromms laikam šo to atsvabināja dvēselē, kas vinuu ilgstoši nodarbināja. Kaut gan - varbūt tieši tāpēc - tā ir „viszinātniskākā” grāmata, ko Fromms ir uzrakstījis, tā ir relatīvi niecīgi recipiēta.

1974. gadā Fromms pārcēla savu mitekli no Kuernavakas (Meksika) uz Lokarno Šveicē, kur viņš I980. gada I8. martā nomira. Savā pēdējā grāmatā "To Have or to Be" [Piederēt vai büt] (1976a, GA II, S. 269-4I4) viņš vēlreiz ietvēra visu, kas viņu bija nodarbinājis gadiem un gadu desmitiem: mijiedarbību starp sabiedrības socioekonomisko struktūru un indivīdu „sabiedrības raksturā” (a.a.O., S. 365 f.), kura aktuāli dominējošo formu atsvešinātajā „mārketinga raksturā” (S. 374 ff.), pakḹāa žilbinošai kapitālisma piederēšanas, patērēšanas un iegūšanas mentalitātes, „industrijas laikmeta reliǵijas” (S. 372 ff.) kritikai, uzdrošināties beidzot spert soli no „brīivibas no” uz „brīvību uz”, „piederēt” orientācijas vietā likt savu „produktīvo būšanu” (S. 304), bet noslēguma nodaļā aplūkoja atseviškzus punktus, izsakot priekšlikumus par darba, saimniekošanas sistēmas un patērēšanas uzvedības izmain,ām, par atbrun,ošanos un „līdzpiekrišanas demokrātiju” (S. 399 ff.), kurus bija iztirzājis jau agrāk.

Jauns šajā grāmatā bija tas, ka Fromms atsedza sava pasaulīgā humānisma spirituālo fonu, saistot Karlu Marksu ar Meistaru Ekhartu (abi pastāv kā svarīgākās alternatīvas galvenie liecinieki), viņš uzrunāja jaunatnes spēju sajūsmināties, toreiz tā ir fiksējama ekoloǵiskajā kustībā un daudzajos alternatīvas dzīvesstila projektos. Tas nodrošināja grāmatai pamatīgus panākumus. Kaut arī toreizējā sajūsma ir noplakusi, Fromma pēdèjā grāmatā aizvien vēl atrodas pietiekami daudz substances, ko apliecina tās noturīgie pārdošanas panākumi.

Vēl viena personiska piezīme: kad aptuveni pirms 30 gadiem sāku nopietni nodarboties ar Ērihu Frommu, viṇa „cel̦u iekšup uz pašiepazišanu”, redzēju vairāk vai mazāk kā pretstatu „ceḷam ārup uz politisko darbību” (Johach,I986, S. 54). Patlaban esmu pārliecināts, ka šeit nepastāv pretstats, gluži pretēji, atsaukšanās uz cilvēcisko potenciālu humānistiskajā relig̣ijā, kuras 
kodolu Fromms visupirms atsedza jūdaismā, bet tad atklāja arī dzenbudismā un kristiešu domātājā Meistarā Ekhartā, nepavisam nenozīmē atkāpšanos no pasaules (lai izteiktos patētiskāk), tas Frommam bija un varbūt mums ir spēka avots, kas ḷauj mums iestāties par patiesi svarīgām lietām cilvēku dzīvē.

\section{No vācu valodas tulkojis Igors Šuvajevs}

\section{Literatūra}

Akrap D., 2011: Erich Fromm - ein jüdischer Denker. Wien-Berlin: LIT-Verlag.

Akrap D., 2013: „eine immer lebendige Quelle”. Erich Fromm als jüdischer Denker. In: Fromm Forum 17/2013, 14-18.

Fromm E., 1922: Das jüdische Gesetz. Zur Soziologie des Diaspora-Judentums. (Dissertation). In. R. Funk (Hrsg.): Erich Fromm Gesamtausgabe (= GA). Stuttgart: Deutsche Verlagsanstalt 1999, Bd. XI, 19-I26.

Fromm E., 1932a: Über Methode und Aufgabe einer Analytischen Sozialpsychologie. Bemerkungen über Psychoanalyse und historischen Materialismus. GA I, 37-57.

Fromm E., 1941a: Die Furcht vor der Freiheit. GA I, 215-392.

Fromm E., 1947a: Psychoanalyse und Ethik. Bausteine zu einer humanistischen Charakterologie. GA II, I-I57.

Fromm E., 1950a: Psychoanalyse und Religion. GA VI, 227-292.

Fromm E., 1955a: Wege aus einer kranken Gesellschaff. GA IV, I-254.

Fromm E., 1956a: Die Kunst des Liebens. GA IX, 439-518.

Fromm E., 1960a: Psychoanalyse und Zen-Buddhismus. GA VI, 30I-356.

Fromm E., 1960b: Den Vorrang hat der Mensch! Ein sozialistisches Manifest und Programm. GA V; 19-4I.

Fromm E., 196rb: Das Menschenbild bei Marx. GA V, 335-393.

Fromm E., 1962a: Jenseits der Illusionen. Die Bedeutung von Marx und Freud. GA IX, 39-168.

Fromm E., 1966a: Ihr werdet sein wie Gott. Eine radikale Interpretation des Alten Testaments und seiner Tradition. GA VI, 83-226.

Fromm E., 1969: Die dialektische Revision der Psychoanalyse. GA XII, 19-7I.

Fromm E., 1973a: Anatomie der menschlichen Destruktivität. GA VII.

Fromm E., 1976a: Haben oder Sein. Die seelischen Grundlagen einer neuen Gesellschaft. GA II, 269-4I4. 
E. Fromm, 1986: Über die Liebe zum Leben. Rundfunksendungen. Hrsg. v. H.-J. Schultz. München: Deutscher Taschenbuch Verlag.

Funk R., 1978: Mut zum Menschen. Erich Fromms Denken und Werk, seine

humanistische Religion und Ethik. Stuttgart: Deutsche Verlagsanstalt.

Funk R., 1983: Erich Fromm. Mit Selbstzeugnissen und Bilddokumenten. Reinbek:

Rowohlt.

Funk R., 1999: Erich Fromm - Liebe zum Leben. Eine Bildbiographie. Stuttgart: Deutsche Verlagsanstalt.

Funk R., 2005: Erleben von Ohnmacht im Dritten Reich. Das Schicksal der jüdischen Verwandtschaft Erich Fromms, aufgezeigt anhand von Dokumenten und Briefen auf dem Wg in die Vernichtung. In: Fromm Forum 9/2005, 35-79.

Hardeck J., 2005: Erich Fromm - Leben und Werk. Darmstadt: Primus-Verlag.

Horkheimer M., 1932: Geschichte und Psychologie. In: Ders.: Gesammelte Schriften, Bd. 3: Schriften 1931-1936. Hrsg. v. A. Schmidt. Frankfurt/M.: Fischer 1988, 48-69.

Johach H., 1986: Analytische Sozialpsychologie und gesellschaftskritischer Humanismus.

Eine Einführung in das Denken Erich Fromms. Dortmund: Alternativverlag für Wissenschaft, Literatur und Praxis.

Johach H., 2000: Gelebter Humanismus. Zeitdiagnose und politisches Engagement. In: Funk; R.; Johach, H.; Meyer, G. (Hrsg.): Erich Fromm heute. Zur Aktualität seines Denkens. München: Deutscher Taschenbuch Verlag, 68-84.

Johach H., 2009: Von Freud zur Humanistischen Psychologie. Therapeutisch-biographische Profile. Bielefeld: transcript.

Löwenthal L., 1980: Mitmachen wollte ich nie. Ein autobiographisches Gespräch mit Helmut Dubiel. Frankfurt/M.: Suhrkamp.

Marcuse H., 1969: Triebstruktur und Gesellschaft. Ein philosophischer Beitrag zu Sigmund Freud. Frankfurt/M: Suhrkamp.

Scholem G., 1977: Von Berlin nach Jerusalem. Jugenderinnerungen. Frankfurt/M:

Suhrkamp.

Wehr, H., 1990: Erich Fromm zur Einführung. Hamburg: Junius-Verlag.

Widerström K., 2013: Einführung in das Leben Erich Fromms. In: Fromm Forum I7/2013, 8-12.

Wiggershaus R., 1986: Die Frankfurter Schule. Geschichte - Theoretische Entwicklung Politische Bedeutung. München-Wien: Hanser. 

Rainers Funks

\section{Jautājums par brīvību 70 gadus pēc Ēriha Fromma darba „Bēgšana no brīvības”}

\section{JAUTĀJUMS PAR BRĪVĪBU VAKARZEMES KULTŪRĀ}

Vakarzemes sabiedrības un kultūras attīstībā cilvēka brīvības jautājumam jau sākotnēji ir centrālā nozīme. Tas noteic jūdaiski kristietisko religíiju gluži tāpat kā filosofiskās domas tradīciju kopš pirmssokratiķiem. Cilvēka brīvība kḷūst iepazīstama norobežotỉbā no Dieva un norobežotībā no dzīvnieka. Tikai grēkotspējīgais Ādams un tikai ar prātu apveltītais cilvēks var apzināties savu brīvību un tāpēc būt brīvs. Turklāt brīvība pastāv tikai cilvēkam iepriekšdoto robežu ietvaros, tas nozīmē -- cilvēka ierobežotības un nosacītības (conditio humana) ietvaros. Katrā ziṇā līdz nesenai pagātnei pastāvēja visai plašs konsenss, ka brīvība nenozīmē nekādu robežu nepastāvēšanu un ka tiekšanās pēc brīvības vienmēr ir tiekšanās pēc lielākas brīvības cilvēciski iespējamās ierobežotības ietvaros. Par to, ka patlaban šis konsenss tiek novietots dispozīcijā, vēlāk tiks iztirzāts vēl detalizētāk.

Vēlme pēc lielākas brīvības Vakarzemes vēsturē gan vienmēr arī saistījās ar brīvību cilvēkam iepriekšdoto robežu ietvaros. Tāpēc psihologiskajā aspektā brīvība visciešākajā veidā ir saistīta ar paša prāta un mīlěšanas spēkiem, ar apgaismību, pilngadību, autonomiju un kompetenci. Taču brīvības jautājuma cīṇas aspekts pirmāmkārtām saistījās nevis ar cilvēkam iepriekšdotajām robežām, bet gan ar cilvēku noteiktajām robežām. Tiešām, lai būtu iespējama 
sabiedriska kopdzīve, vienmēr jābūt noteiktiem arī likumiem un līdz ar to papildus jāierobežo atsevišķā indivīda un daudzo brīvỉbas iespējas. Par šādi noteikto robežu apmēriem un iedarbību, par to leǵitimitāti un pārvarēšanu arī ir runa Vakarzemes brīvības cīṇās kopš viduslaiku beigām.

Šo brīvības jautājuma emancipatorisko aspektu Ērihs Fromms tematizē savā grāmatā „Bēgšana no brīvības”. ${ }^{1}$ Kaut arī viduslaiku pasauli Fromms aizvien no jauna apraksta saudzējošiem vārdiem, nav nekādu šaubu, ka šo pirmsmoderno pasauli, kurā kopdzīvi un pašpārdzīvojumu pirmāmkārtām virza tradētais, tradīcija, vajag atstāt. Sevis paša Es pārdzīvošana pirmsmodernajā pasaulē ir iespējama tikai saistībā ar Mēs un atbilstīgi tā uzstādījumam. Baznīcas, zemeskungu aizbildniecība un stingri izveidotie kārtības veidi rada kolektīvas spīles, kas gan sniedz drošību un aizsardzību, taču nekādā ziṇā neveicināja individualitāti. Gluži pretēji: kas šādi turējās pie noteiktajām robežām, tas kavēja attīstīt savu individualitāti un izsmelt potenciālu iepriekšdoto robežu ietvaros, kuras viņu subjektīi dara brīvu.

Uznākošais birǵerisms, renesanses humānisms un reformācija daudz ko sniedza jaunlaiku brīivibas izpratnei. Šì brīvības izpratne vienmēr tiecas gan pēc brīvības „no”, gan pēc brīvības „uz”. Runa ir par brīivibu no kundzības un aizbildniecības un par brīvību no kolektīiām saistībām, pazemošanas un ierobežojumiem, tā manifestējas visdažādākajos emancipācijas centienos. Un

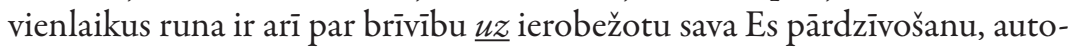
nomiju, individualitāti un pašatbildību, kas manifestējas pilsoṇtiesībās un cilvēktiesībās, kā arī tiesību un to izmantošanas nostiprināšanā, nostiprinot to kā trešo lielumu starp atseviškso indivīdu un kolektīvu.

\section{2. ĒRIHA FROMMA BRĪVĪBAS PSIHOLOGIJA}

To, ka Ėrihs Fromms savu pirmo grāmatu ir nosaucis par „Bēgšanu no brīvības" [Escape from Freedom], var pārprast, it kā viṇam būtu svarīgi izvairīties no brīvības un ka viņš gribētu rast patvērumu kaut kur pirmsmodernajā pasaulē. Varbūt tas izskaidro to, ka dažus gadus vēlāk Lielbritānijā grāmata tika publicēta ar nosaukumu „The Fear of Freedom” - „Bailes no brīvības”. Ar šo nosaukumu kḷūst skaidrāks, ka Frommam ir svarīga brīvības jautājuma psihologiskā perspektīva. Fromms tiešām kā pirmais psihologs analizē modernā cilvēka brīvības problemātiku. Cilvēka atbrīvošanās psihologiija, psihologija 
par cilvēka atbrīvošanos no vēsturiski tapušajām kundzības pretenzijām ir šìs grāmatas galvenā tēma.

Manā ieskatā pastāv vēl divas blakustēmas. Viena no tām ir autoritārisma un autoritārā rakstura psihologiskais izskaidrojums. Otra tēma ir jautājums, kā psihologiski izskaidrojams tas, kas, balstoties uz saimnieciskiem un sabiedriski kulturāliem sasniegumiem un prasībām, cilvēkiem ir jādara, bet noslēdzas ar to, ka beidzot viņi paši pēc tā kaislīgi tiecas. Darba „Bailes no brīvības” pielikumā Fromms izvērš savu sociālā rakstura teoriju. Viņš parāda, ka līdztekus individuālam raksturveidojumam pastāv arī cits psihisks struktūrveidojums: sabiedriskā pielāgošanās spaida dēḷ cilvēks attīsta arī centienus un vērtību priekšstatus, kas viṇu pasargā no tā, ka viņš tiek sabiedriski izstumts vai viṇam jāpaliek bez panākumiem. Šādiem raksturveidojumiem šī funkcija ir pat tad, ja tie ir kontrproduktīvi attiecībā pret cilvēka labbūšanu. Tikai ar šādām sabiedriski harakterologiskām atziņām, saskaņā ar Fromma atziṇām, var izskaidrot, piemēram, to, kāpēc Vācijā sīkburžuāzija palīdzēja uzvarēt un kāpēc daudzi vācu strādnieki, kas atzinās kreisumā, necīnījās pret nacionālsociālismu.

Izejpunkts Fromma sabiedrības rakstura teorijai un arī viņa brīvības psihologijai ir atziṇa, ka cilvēks ir saistības būtne. ${ }^{2}$ Cilvēks nav nekas cits kā savstarpēji, ar īstenību un sevi pašu saistīta būtne. Tāpēc viñam ir vislielākās bailes, ka vairs nespēs adekvāti apmierināt savas vajadzības pēc saistības. Kolīdz viņa vajadzība pēc saistības tiek masīvi apdraudēta un kolīdz viņam draud iekrišana izolētā nekurienē, viņš mēgeina izveidot sargājošu saistību tikai pats ar sevi (piemēram, autismu) vai ārprātīgu saistību (šizofrēnijā vai paranojā). Pat šādas atdalošas saistības formas ir labākas nekā izciest būšanu bez saistības. Tāpēc vissvarīgākais psihiskās attīstības aspekts un vislabākais psihiskās veselības garants ir izveidot iekšējus tēlus un reprezentācijas par labvēlīgu, noturīgu un uzticības vērtu saistību. Tas, ko mēs psiholoǵiski dēvējam par struktūrveidojumu vai arī par raksturveidojumu, nav nekas cits kā šādu iekšèju tēlu izveide, kas nodrošina pirmuzticību īstenībā, citos cilvēkos un mūsos pašos. Kā iekšķ̌īgotu saistības pieredzi to visnotal, grūti atņemt aktuālai pretējai pieredzei. Šì pieredze pamato to, kas psihologijā tiek dēvēts par patību. Tā nodrošina saistību ar ārējo īstenību, citiem cilvēkiem un mums pašiem, kaut arī neesam atkarīgi no to reālās klātbūtnes un apliecinājuma. 
Lai mēs justos nozīmīgi un labi, nav aktuāli nepieciešami apliecinošie cilvēki; lai spētu kādu mīlēt, mums nepavisam nav aktuāli pirmāmkārtām gūt pieredzi, ka citi mūs mīl. Lai spētu būt vienatnē, nav nepieciešams permanents apstiprinājums, ka netiks atstāts vienatnē; lai spētu būt aktīvs, nepavisma nav tā, ka sākumā mūs nepieciešams aktivēt. Jo lielāka ir mūsu pieredze par pašbūšanu un atkarību no svešiem spēkiem, jo daudzveidīgāka un spēcīgāka kḷūst mūsu patība, šādi arī brīvāk pārdzīvojam sevi un esam brīvāki. Tāda, nedaudz vienkāršoti izklāstot, ir Fromma brīvības psihologiija.

\section{BAILES NO BRĪVĪBAS UN JAUNLAIKU INDIVIDUALIZĒĚSANĀS}

Mācītais sociologs un psihoanalītiķis Fromms atsevišķo cilvēku aptvēra ne tikai kā vienmēr jau saistītu būtni; tieši tāpēc, ka viņš pastāv tikai kā saistīta būtne, viņu jāaptver arī kā sabiedriskotu būtni. Atškkirībā no vairums psihologiem, kas indivīdu redz pretstatītu sabiedrībai, saskaņā ar Fromma domām, atsevišķaais indivīds nav šķirams no sabiedrības, kurā viņš dzīvo. Katram cilvēkam kaut kādā veidā jātiek galā ar sabiedriskās kopdzīves prasībām, lai nepakḷautu sevi briesmām izkrist no sabiedriskajām attiecībām un tikt izstumtam. Tāpēc, pēc Frommu domām, sabiedrības rakstura psihiskajam struktūrveidojumam ir tik liela nozīme. Šādi Fromms izskaidro to, ka kaut kādas sabiedrības grupas locekḷi domā, jūt un rīkojas līdzīgi tāpēc, ka viṇi ir iekšķ̣īgojuši sabiedriskās kopdzīves prasības, lai pastāvētu kā sabiedrību saturoši dzinējspēki.

Dziḷākais cēlonis šai pielāgotībai sabiedrībai arī šajā gadījumā ir vajadzība pēc saistîbas un eksistenciālās bailes pazaudēt saistîbu ar sabiedrību. Tikai ņemot vērā šo atziṇu, kḷūst saprotams, cik draudīgs atsevišķajam indivīdam ir individualizācijas process, kas sākās līdz ar Vakarzemes jaunajiem laikiem.

Pat ja atšķirība starp pirmsmoderno un moderno cilvēku ir plakātiska un skaidri atpazīstama kḷūst tikai pēc gadu simtiem, tad tieši psihologiskajā perspektīvā tā ir l, loti produktīva. Tà signalizē par atšķirīgu sociālās kopbūšanas un Es uztveres veidu. Kad pirmsmodernais cilvēks saka „es” un grib pats sevi uztvert kā patstāvīgu lielumu - tiešām kā „Es”, tad viņš vienmēr pārdzīvo sevi kā dal̦u no kopības, kas viṇu nes, sargā, godina un piedāvā mājvietu. Bez šis kopības viṇa Es ir nepamatots; viṇa Es [veidojumam] nav fundamenta bez tā piederības to nesošajam Mēs [veidojumam]. Viṇa 
personiskie vērtībpriekšstati ir tās kopības vērtībpriekšstati, saistībā ar kuru viņš sevi pārdzīvo kā tās daḷu.

Uzdrošinoties nošķirties no šādām kopības attiecībām un dzīvot savu sabiedrisko saistīto būšanu neatkarīgi no kopības un aptvert sevi kā brīvu indivīdu, cilvēki psihiskā ziṇā nokḷūst dzīves briesmās. ${ }^{3}$ Daudzas līdz tam derīgās viṇu saistītās būšanas īstenošanas formas vairs nepastāv, tā ka viṇiem draud psihiska krišana. Bet tieši tas arī ir domāts, kad Fromms runa par bailèm no brīvibas.

Individualizācijas process, kas Vakarzemē aizsākas ar jauniem laikiem, ir îstenojies nelielos posmos, ar daudziem kompromisveidojumiem - atliek vien atcerēties absolūtisma laikus -, taču tas ir piedzīvojis arī forsētu attīstību, kas novedusi pie apgaismības filosofijas, pie franču revolūcijas un pie Billof Rights. Vakarzemes izglītības sistēma un psihologijas rašanās i9. gadsimtā nav iedomājama bez individualizācijas procesa.

Darbā „Bailes no brīvības” Fromms apraksta jaunlaiku individualizācijas procesu. Viņš ieskicē arī ši procesa mērḳi: brīvo indivīdu, kurš pēc paša iniciatīvas - sua sponte - spēj būt aktīvs. Šāds cilvēks, cik nu tas iespējams, mēgeina būt neatkarīgs no svešiem spēkiem un apmierina savas vajadzỉbas pèc saistības pats ar saviem prāta un mīlestības spēkiem. ${ }^{4}$

Mērķis ir novietots augstu, ņemot vērā bailes no izolācijas un nenozīmīgumu, kas aizvien vēl ir daudzus pārņēmuši un kas tiem liek meklēt bēgšanas ceḷus. Tā, piemēram, darbā „Bailes no brīvības” Fromms detalizēti apraksta, ka daudzi cilvēki savu laimi vairs nemeklē pirmsmodernā kopībā, viņi pakḷaujas personificētai autoritātei, vadonim un dučem. Viṇi attīsta autoritātu sabiedrības raksturu, kas daudzos aspektos atgādina pirmsmoderno sabiedrības konstrukciju. Tieši nacionālsociālisms ar saviem rasistiskajiem priekšstatiem un savu tautisko kopības ideolog̣iju no jauna atdzīvināja un instrumentalizēja pirmsmoderno kopību.

Tas ir Ē. Fromma zinātniskais nopelns, ka viņš atpazina tādu, piemēram, raksturveidojumu kā autoritārais raksturs un konformistiskais mārketinga raksturs atkarību no laika noteiktajām saimniekošanas un sociācijas prasībām un aprakstīja to psihisko dinamiku. ${ }^{5}$ Rodas jautājums, kā ir attīistījies individualizācijas process 70 gadus pēc grāmatas „Bēgšana no brīvības" [Escape from Freedom] publicēšanas un kādi raksturveidojumi pastāv patlaban? 


\section{TAGADNES BRĪVĪBAS JAUTĀJUMS}

Tas, ka tā sauktajās Rietumu zemēs pēdējos 50 gados ir radusies jauna individualizācijas procesa dinamika, ir nolasāms jau no daudzajiem mēgéinājumiem, kas jaunajam laikmetam ir devuši nosaukumu. Mēdz runāt par postmodernismu vai otro modernismu, tiek runāts arī par to, ka modernisms nokḷuvis pats pie sevis. Citi patur vērā kapitālistiskās saimniecības pārmaiṇas un runā par neoliberālismu un neoliberālu saimniecības filosofiju. Vēl citi visu laimi saskata visu ierobežojumu atcelšanā. Viņi tic liberalizētā tirgus pašvirzībai un ir pārliecināti, ka arī sabiedrības un kultūras procesos darbojas pašas sevi virzošas sistēmas ar iebūvētām korekcijām.

Lai no kādas perspektīvas arī skatītu tagadējo individualizācijas procesa pārmaiņu, acīmredzot aizvien ir runa par mainījušos brīvības izpratni un par citu attieksmi pret ierobežojumiem un robežām. Pirms runāšu par jaunu raksturveidojumu, vēl nedaudz jāieskicēe šī pārmaiņa brīvības izpratnē.

\section{A) BRĪVĪBA KĀ ATBRĪVOŠANĀS NO IEPRIEKŠDOTĀM ROBEŽĀM}

Jau tika runāts par divām atškịīīām brīvības izpratnēm. Brīvība, tika teikts, pastāv tikai cilvēciski iespējamā ietvaros, tā ka brīvību var pārdzīvot un praktizēt tikai iepriekšdoto robežu ietvaros. Taču, no otras puses, kopdzīves nolūkiem pastāv daudzas pašu noteiktas robežas, kas individualizācijas procesā pamatoti novērstas, lai nodrošinātu individuālo brīvību.

Bet vai aizvien ir spēkā pirmais izteikums, ka brīvība ir realizējama tikai cilvēciski iespējamā iepriekšdotajās robežās? Šīs robežas gan individualizācijas procesā vai tehniskās attīstības procesā var pavirzīt aizvien tālāk. Tomēr iegūtā brīvība aizvien vēl ie ierobežota. Varbūt tomēr nav? Vai tieši patlaban netiek runāts par iespēju pārdzīvot brīvību kā neierobežotỉbu? Vai netiek realizēta pavisam cita autonomijas dimensija - proti, pašnoteikšanās un Esteikšana, kas grib, lai neviens un nekas - arī iepriekšdotā realitāte - neko nespētu tai priekšrakstīt? Vai netiek novērstas robežas visos līmeņos, arī tādas cilvēciski iespējamā robežas, par kurām domāja, ka tās nevar novērst, jo tās attiecas uz conditio humana, cilvēkbūšanas priekšnosacījumiem?

Filosofiski pamatoti vai vienkārši faktiski praktizēti [indivīds] iestājas par konstruktīvismu, kurā visnotal, pareizā atziṇa, ka jebkurš uztvērums un atziṇa ir pakḷauta konstrukcijas logikai, tiek vispārināta: atbrīvots no visa, 
kas varētu to ierobežot un definēt, cikvēks ir tas, ko viņš no sevis uzkonstruē. Kaut kas saistošs, būtisks, nosacīts, kas varētu ierobežot viņa neierobežoto īstenības konstrukcijas brīvību, vairs nav redzes laukā.

Šàdi ir dots arī mājiens par to, ka neierobežotā brīvība un autonomija ir realizējama ar pašnoteiktu īstenības konstrukciju, kura visu, kas varētu ierobežot cilvēka brīvību, tiecas novērst un izskaust. Katrā ziṇā vācu valodā šādai robežu novēršanai ir savs vārds. Šis vārds ir Ent-grenzung [at-robežot], tas jau savā etimologijā vienmēr ir nozīmējis, ka robežas tiek pārvarētas, tās novēršot. Ja ierobežojumi realitātē nav novēršami, tad vajag atrobežot realitāti, izskaužot un noliedzot ierobežoto realitāti un aizstājot to ar simulētu un virtuālu realitāti. ${ }^{6}$

Šādas īstenības konstrukcijas patlaban nav nedz utopiskas, nedz - kā līdz šim - ierobežotas ar izņēmuma situācijām. Neierobežotības īstenības konstrukcijas ir pastāvējušas vienmēr: psihozēs, sapņos, reibumā, transā, regresijā vai unio mystica. Patlaban, pateicoties digitālai tehnikai, elektroniskiem medijiem un satīklotības iespējām, atrobežotās īstenības konstrukcijas kḷūst pieejamas ikvienam, jebkurā laikā un jebkurā vietā.

Daudzas īstenības konstrukcijas var inscenēt, un gandrīz jebkuru îstenības konstrukciju vismaz pārejoši var padarīt par savu kā virtuālo realitāti. Jo vairāk cilvēki ar suǵestīvām un autosuǵestīvām tehnikām ievingrinās dzīvot simulētās īstenībās, jo neproblemātiskāk izdodas ilgstoši neierobežotas brīvības realizācija.

Katrā ziṇā psiholog̣iskā perspektīvā šim nolūkam ir vajadzīgi cilvēki, kam arī iekšéji piemīt vēlme îstenību ap sevi un īstenību, kas viņi ir paši, „izdomāt no jauna” - kā tas skan jau ikdienas valodā. (Patlaban visu vajag izdomāt no jauna: cilvēku, politiku, izglītību un, protams, arī Latviju.) Vismaz mājienveidā jāparāda, kādas tagadējās dzīves iespējas un prasības raisa raksturorientāciju, kas cilvēkiem aizvien vairāk liek no jauna izdomāt īstenību, lai varētu sevi pārdzīvot neierobežoti brīvi.

\section{B) ATROBEŽOŠANAS IESPĒJAS UN PRASĪBAS}

Sekojot Ē. Fromma sociālpsiholog̣iskajam aizsākumam, jaunas sabiedrības raksturorientācijas aizvien rodas no sabiedrības vai sabiedrības grupas izmainītajām dzīves attiecībām, ar kurām daudziem atsevišķiem indivīdiem vajag sadzīvot. Turklāt jaunās dzīves attiecības rodas ne tikai no politiskām 
un sociālām pārmaiṇām, bet arī no revolucionārās tehniskās attīstības un transformētām saimnieciskās producēšanas un distribūcijas iespējām.

Ar digitālo tehniku, elektroniskajiem medijiem un satìklošanas tehnikām izraisītā „digitālā revolūcija” ir aizsākusi līdz šim gandrīz vai neiedomājamu atrobežošanas dinamiku, kas ir pārmainījusi visas pētniecības un dzīves jomas. Digitālā tehnika un elektroniskie mediji ir svarīgs priekšnosacijjums tagadējai atrobežotībai no telpas un laika, no zināšanu un informācijas pārneses sekundes ātrumā, no tēlveidojošas darbības, kas atklāj pilnīgi jaunas izziṇas iespējas, piemēram, smadzeṇu pētniecībā vai diagnostikā, no mērīšanas, kas nekad netika uzskatīta par iespējamu, bet kas, piemēram, atver vārtus uz nanotehniku, priekšnosacījums komunikācijai, kas nav atkarīga no telpas un laika, zināšanu ieguvei vai laika pakavēšanai; gandrīz visu ražošanas procesu un tajā iesaistīto mobilizācijai, globalizācijai un fleksibilizācijai; ǵenētiskā koda atšifrēšanai vai Visuma izpētei.

Nav šaubu, ka pēdējo 40 gadu digitālā revolūcija ir izškirīgi veicinājusi to, ka līdz šim nepārvirzāmās robežas ir pilnīgi izšķīidušas. Tāpēc arī nav nekāds brīnums, ka robežu novēršana ir kluvusi par brīnumlīdzekli saimniecības organizēšanā (atliek tikai atcerēties finanšu tirgus liberalizēšanu), kā arī darba organizēšanā. Lìdz šim darba pasauli bija iezīmējušas mūžilgas profesijas un ilgstošas darba attiecības, pastāvot stabilām peḷnas iespējām un sociālām nodrošināšanas sistēmām, šie sargājošie ārējie balsti pakāpeniski sabrūk. Tagad draud „netipiskas” nodarbošanās attiecības (piemēram, iznomātais darbs) un beztermiņa darba līgumu zudums. Strauji palielinās darbs maiñās, nakts darbs, darbs nedēḷas nogalē un svētdienas darbs - neraugoties uz iespaidīgajiem datiem par kaitējumiem veselìbai un gimenes un sociālo konfliktu potenciālu, kas iet roku rokā ar šiem atrobežojumiem.

Neatkarīgi no tā, vai atrobežošanas dinamika tiek pārdzīvota pozitīivi vai negatìvi, tā ir sociāla realitāte, no kuras reti kurš var izvairīties. Tādējādi neatliek nekas cits, ka aizvien vairāk cilvēku attīsta sabiedrības raksturorientāciju un ka viṇus virza vēlme pašiem noteikt to, kas ir īstenība, lai spētu ìstenot pašnoteiktu un brīvu dzìvi.

\section{C) ES-ORIENTĒTAIS SABIEDRĪBAS RAKSTURS}

Es šo sabiedrības raksturu esmu nodēvējis par „Es-orientētu”, 7 jo šādus cilvēkus virza spēcīga vēlme, brīvi no visām robežām, saistībām pašiem noteikt 
visu, kas attiecas uz dotumiem un mērogiem. Kaut arī viņu izturēšanās šķiet egoistiska vai narcistiska, parasti tas tā tomēr nav. Drīzāk jau viṇi ir izstrādājuši jaunu izpratni par autonomiju, kas necieš nekādas saistības, un tiecas ar atrobežojumiem būt brīvi. Tāpēc viṇi ir pārmēru sensibli pret visu, kas viņus varētu saistit un ierobežot vai kur nojauš citas saistības un robežas. Viṇi tiecas atrobežot un novērst visu, kas varētu ierobežot viņu pašnoteikšanos, tāpēc tā ir galvenā šĩ sabiedriskā raksturveidojuma pazīme.

Tiekšanās pēc neierobežotības patlaban pastāv visā sabiedrībā. Īpaši iespaidīgi tas izpaužas jaunos cilvēkos un tajos, kas profesionāli darbojas mediju pasaulē un n,emas ar īstenību jaunu konstruēšanu un mediālu pastarpināšanu. ${ }^{8}$ Šis empīriskais novērojums norāda uz citām jaunā raksturveidojuma atpazīšanas pazīmēm: uz kaislīgo vēlmi konstruēt îstenību no jauna un citādi un dot priekšroku atrobežotām īstenībām. Jauno brīvību var plaši realizēt tikai tad, ja ir pieeja no jauna konstruētām īstenībām, resp., ja pats spēj radīt šādas īstenības.

Jaunais raksturtips pastāv divās izpausmēs. Lìdzīgi kā autoritārā rakstura gadījumā, kas pastāv izteiktākā sadistiskā vai mazohistiskā orientācijā, arī šajā raksturā, kas tiecas pēc neierobežotas brīvības, var izšķirt aktīvu un pasīvu versiju. Aktīvais tips grib pats no jauna radīt savu appasauli, savu dzīves stilu un savu pārdzīvojumu pasauli, turpretim pasīvais grib pašnoteicoši piedalīties atrobežotajā īstenībā. Pasīvais tips izraugās dzīvespasauli, lifestyle, marku, mūzikas stilu un events, kas viņam vai viņai ir piemēroti.

Atbilstīgi citāds ir arī meklētais pašpārdzīvojums. Pasīvais tips grib būt Es, kas ir saistīts un tam piederīgs. Jo tikai šādi viṇš var atrobežoti pārdzīvot. Mēs-izjūtas pārdzīvojumā viņš jūt savu Es. Būt saistītam - tas viņu dara brīvu. Pašnoteikšanās un saistība tik l, loti izslēdz, ka jebkura saistība nozīmē atkarību un līdz ar to - ierobežotību, tāpēc tik svarīga un nozīmīga ir pašizraudzītās saistības pārdzìvošana. No pirmsmodernā cilvēka viņa vēlme būt saistītam atšķiras ar to, ka jaunais raksturs vēlas būt saistīts pašnoteicoši - tieši ar tiem cilvēkiem vai vietām, kas viñam vai viñai ir piemēroti. Tātad pastāv ne tikai jauna Es-teikšana un Es-pārdzīvošana, bet arī jauns socialitātes un kopjēgas veids - jauna Mēs-pārdzīvošana, kas ir projektsaistīta un notikumiem pilna, taču necieš nekādas saistības.

Vēlmi konstruēt īstenību no jauna un citādi, resp., ienirt inscenētās un simulētās īstenībās, pavisam droši pastiprina tagadējās mediālās iespējas, kas 
konstruēto īstenību var padarīt daudz spriegāku, pārdzīvojumiem bagātāku un atraktīvāku nekā ir dotā realitāte. Izpētot jautājumu, kurās situācijās cilvēkiem ir kāpināta vajadzība ienirt inscenētās un simulētās pasaulēs, l,oti ātri kḷūst skaidrs, ka viņi tiecas izbēgt no pārlieku ierobežota vai apgrūtinoša dvēseliskā uzskan,ojuma. Inscenētās un simulētās īstenības sniedz nedrošo „priekšrocību”, neatkarīgi no paša uzskan,ojuma un personiskajām dzīves gaidām spēt pārdzīvot apmierinājumu un laimi.

Vēlme atrobežot realitāti attiecas ne tikai uz mūs aptverošo īstenību. Arī mūsu pašu personība ar visām tās šķautnēm, nīstamām iezīmēm un agresīvām izpausmēm ir atrobežojama, piemēram, ar mentālu mūsu jūtu dzīves pārkonstruēšanu. Šādas pārkonstruēšanas daudzās profesijās attiecas jau uz personības veidošanu. Ar psihotehnikām panāk ietrenētību būt nevis vairs īgnam, kritizējošam, negribīgam vai nemotivētam, bet gan vienmēr tikai draudzīgam, novērtējošam, piekrītošam un empātiskam. Un tad tā arī ir: simulētās jūtas kḷūst par personības atribūtiem, bet to, ko jūt attiecīgā persona, tā vairs nezina arī pati.

\section{NEIEROBEŽOTĀ BRĪVĪBA UN BAILES NO REALITĀTES}

Noslēgumā ir jautājams, vai raksturs, kas tiecas pēc neierobežotas brīvỉbas, ar savu jauno autonomijas izpratni iemieso jaunu laikmetu individualizācijas procesā un nodrošina jaunu individuālās brīvības kvalitāti vai arī (gluži kā autoritārais raksturs) īstenībā ir bēgšana no brīvības? Šādā gadījumā - gluži kā kundzības idealizēšanā un paḳ̣aušanās autoritārā rakstura gadījumā - pašnoteicošā tieksme pēc atrobežošanās būtu uzlūkojama kā izmisis mēginājums tikt galā ar dziḷi sakņotām bailēm, dzīvojot pilnīgi nesaistīti un bez kādām attiecībām desolidarizētā un atomizētā sabiedrībā. Pats brīvi nosakot to, kas ir īstenība un kāda îstenība man ir panesama un sniedz balstu, un vairs neesmu spiests skatīties acīs šai manai sabiedrības realitātei.

Ēriha Fromma darbs „Bailes no brīvības” nav neko zaudējis no savas aktualitātes, jo līdz ar progresējošo individualizācijas procesu un tagadējām neierobežotās brīvības iespējām bailes no šīs brīvības drīzāk ir pastiprinājušās. Ja cilvēks nav nekas cits kā sabiedriskota būtne, tad daudzu sabiedrisko saistību un attiecību iziršana viṇam ir jāuztver kā eksistenciāls apdraudējums. 
Tomēr, ņemot vērā jauno raksturveidojumu, nav pamatoti runāt par bailēm no brīvības. Cilvēki, kas iestājas par īstenības pašnoteikto atrobežojumu, mīl šo brīvību un nebaidās no tās. Tas, no kā viņi baidās, ir realitāte, ierobežotā realitāte, nežêlīgā realitāte, ambivalentā, apšaubošā un kritizējošāà realitāte. Viṇi baidās no realitātes un dzīves prasībām un bēg pašu virzītajā īstenības konstrukcijā, kas ir brīva no nepatīkamiem robežu pieredzējumiem. Tādējādi noslēgumā veidojas atziṇa, ka robežām un arī nepatīkamiem robežu pieredzējumiem jābūt kaut labam.

\section{No vācu valodas tulkojis Igors Šuvajevs}

\section{Vēres}

I Fromm E. Die Furcht vor der Freiheit (1941a) in: Erich Fromm-Gesamtausgabe in I2 Bänden. Hrsg. von Rainer Funk. München (Deutsche Verlags-Anstalt und Deutscher Taschenbuch Verlag), 1999. (Turpmāk citēts kā GA.)

2 Es šeit apzināti neizmantoju jēdzienu „Bindung” [piek̦eršanās], kas ieviesies psihologijāā, pateicoties salīdzinošajai etologijai (piemēram, Boulbija darbos) un zīdaiņu izpētei (piemēram, Einsvorta u.c. darbos), es izmantoju Fromma ieviesto jēdzienu „Bezogenheit” [saistība] (pirmāmkārtām sk.: Fromm E. Wege aus einer kranken Gesellschaft (1955a), GA IV, S. 25-39). Jēdzienus „pieķeršanās” (attachment) un „saistība” (relatedness) var izmantot kā savstarpēji aizstājamus jēdzienus, ja pastāv konsenss, ka runa ir par piek̦eršanās, resp., saistības veidu. Tiesa, vismaz Vācijā ar jēdzienu „Bindung” konotējas pieķeršanās, kas apgrūtina indivudētās saistības izpratni.

3 To, cik draudīga ir šāda sabiedriskās saistītās būšanas maina, patlaban var empīriski apstiprināt ar augsto procentu līmeni starp emigrantiem, kas cēlušies no kolektīvi organizētiem etnosiem un psihiatriski saslimst. Arī sodu ziṇā un forensiskā aspektā migrantu daudzums ir nesalīdzināmi lielāks. Psihologiski šādu attīstību kriminalitātes virzienā var visnotal labi saprast kā patoloǵisku pašnorobežošanos, balstoties uz traumatiski pārdzīvotu sabiedrisko izolāciju.

4 Sk.: Die Furcht vor der Freiheit (1941a), GA I, S. 367-378.

5 Sabiedrības jeb sociālā rakstura konceptu Fromms ir izstrādājis jau trīsdesmitajos gados (sk.: Fromm E. Die Determiniertheit der psychischen Struktur durch die Gesellschaft. Zur Methode und Aufgabe einer Analytischen Sozialpsychologie. 1992e [1937]). GA XI, S. I29-175) un pirmo reizi publicējis kā pielikumu grāmatai „Bailes no brīvības” (GA I, S. 379-392). Kopsavilkums ir sniegts darba „Viṇpus ilūzijām” 8. nodậā (I962a, GA IX, S. 85-95). Sk. arī: Funk R. Psychoanalyse der Gesellschaft. Der Ansatz Erich Fromms und seine Bedeutung für die Gegenwart. In: Funk R., Johach H., Meyer G. (Hrsg.). Erich Fromm heute. Zur Aktualität seines Denkens. München: Deutscher Taschenbuch Verlag, 
2000, S. 20-45; kā arī: Funk R. Mehr als nur Intersubjektivität. Der sozialpsychoanalytische Ansatz Erich Fromms. In: Forum der Psychoanalyse, 27, 2001, Heft 2.

6 Sk. par to: Funk R. Der entgrenzte Mensch. Warum ein Leben ohne Grenzen nicht frei sondern abhängig macht. Gütersloh (Gütersloher Verlagshaus), 20 II.

7 Funk R. Ich und Wir. Psychoanalyse despostmodernen Charakters. München (dtv), 2005.

8 Sk. empīriska pētījuma rezultātus par „Es-orientēto raksturu”: Frankenberger R. Die postmoderne Gesellschaft und ihr Charakter. In: Frankenberger R., Frech S., Grimm O. (Hrsg.). Politische Psychologie und Politische Bildung. Gerd Meyer zum 65. Geburtstag. Schwalbach (Wochenschau), 2007, S. 167-187, ipaši: S. I8I ff. 
Fromms un Latvija 

Maija Kūle

\section{Brīvības problēmas mūsdienu Latvijā Ëriha Fromma analītiskās sociālpsiholoǵijas kontekstā}

Ērihs Fromms ir pasaulē pazīstams kā autors, kas spilgti un trāpīgi rakstỉjis par analīitskās sociālpsiholog̣ijas, psihoanalīzes, kultūras un sabiedrības jautājumiem. Viņa redzeslokā ir nonākušas gan sabiedrības, gan personību attīstības problēmas, saskatot tajās bezapzinātos strāvojumus, kaislību diktētus notikumus, (ne)tiekšanos uz brīvỉbu, destruktīvu personību un manipulāciju spēku. Cilvēki vēlas brīi dzīvot un izdzīvot, taču bieži tas nav vienkārši un pašsaprotami. Nepieciešamas izdzīvošanas stratēǵijas, spēja orientēties apkārtējā pasaulē un izprotoši realizēt savu brīvību.

Tematika, ko savos darbos aplūkojis filosofs, rezonē ar Latvijas un Eiropas sabiedrības aktualitātēm 20. gadsimta beigu posmā un 21. gadsimtā: tās ir izdzīvošanas stratégijas laika posmā, kad sabrūk PSRS, notiek valstiskuma atjaunošana Latvijā 1990.-1991. gadā, ko pavadīja brīvibas centieni un nacionālās identitātes meklējumi, tās ir 21. gadsimta sākuma ekonomiskās un sociāāās krīzes. Fromma mācība tādējā̉i ir vērtīga arī Latvijas sabiedrības sociālpsihologiskajā un kultūras psihoanalītiskajā skatỉjumā, jo tā dod filosofiskus izpratnes modelıs.

$\bar{E}$. Fromms savos darbos analizē, kā darbojas tirānu ietekmes mehānisms. Tirāni ir bijuši pasaules vēstures sastāvdal̦a, un vinu vara allaž balstās uz despotisma savienošanu ar masu pakḷaušanu. Bet kāpēc masas pakḷaujas? 
Kāpēc cilvēki bēg no brīvības un bailēm ir tik liels spēks? Despotu spēks un vājums atainojas, piemēram, Stal̦ina personības kulta psihologisko un sociālo sakṇu analīzē, kam pieskāries arī Fromms. 1990. gados gan krievu, gan citās valodās tika publicēts daudz analītiskās literatūras par Stalina režīmu, ${ }^{1}$ tagad tas diemžēl ir sarucis. It kā jautājums par autoritāru personu spējām pakḷaut sev sabiedrību būtu kḷuvis maznozīmīgs.

Tomēr šì jautājuma aktualitāte nonāk dienaskārtībā sakarā ar Putina kā Krievijas Federācijas prezidenta darbību, cenšoties palielināt Krievijas ietekmes spēku pasaulē. Spilgti tas redzams Krievijas agresijas gadījumā pret Ukrainu, sākot no 20I4. gada marta, kad notika neleǵitīms referendums Krimā un Krima tika pievienota Krievijai. Levadas centra socioloğiskās aptaujas Krievijā parādīja ${ }^{2}$, ka prezidenta reitings tūlīt strauji palielinājās, cilvēku sociālpsihologiskās noskaņas rezonēja ar bezapzināto vēlmi būt varenai, spēcīgai un savu varu diktējošai krievu tautai. Ideologija kā sabiedriskās domas veidošanas ierocis ar mediju palīizību strādāja spēcīgāk nekā daudzu personiskās vēlmes iegūt savu viedokli. Tipiska bēgšana no brīvības. Tas, ka Krievijas mediji gandrīz vienprātīgi paḳ̣āvās politiskās varas diktētajām notikumu interpretācijām, divām trešdal̦ām no sabiedrības nelikās būtiski. Tieksme un iespējas saṇemt neatkarīgu informāciju samazinājās, jo daudz lielāks bija prieks par varenības izjūtas atjaunošanos, kas ir psihoanalītiski analizējams fenomens.

E. Fromma grāmatas „Piederēt vai būt” un „Bēgšana no brīvības”, „Cilvēka destruktivitātes anatomija” gan oriǵinālā, gan tulkojumos kḷuva par pastiprinātas intereses objektiem pārejas periodā no padomju iekārtas uz jauno kapitālismu Latvijā. Viṇa risinātie jautājumi bija un ir svarīgi arī mūsdienu Latvijā.

\section{BRĪVĪBA KĀ ĒRIHA FROMMA FILOSOFIJĀ APLŪKOTA VĒRTİBA UN TĀS MEKLĒJUMI LATVIJĀ}

Latvijas vēsturē brīvības centieni ir attēloti gan mākslā un literatūrā, idejās par indivīda atbrīvošanu no sociāliem un ekonomiskiem spaidiem, kustībās par sociālo grupu un sieviešu emancipāciju, nostādnēs par tautas atbrīvošanos un brīvu valsti. Jēdziens „brīvỉba” latviešu valodā sāk nostiprināties līdz ar jaunlatviešiem. I8./ı9. gs. mijā tam ir nozīme „at ̣̦auja, privilēgija”, 
tātad - brīvība ir privilēgija, izṇēmuma stāvoklis. Taču vēstures process virzījās uz to, lai tā kḷùtu par visiem pieejamu vērtỉbu.

Vēlāk vārda „brīvība” nozīme Rietumu kultūras ietekmē Latvijā tiek paplašināta, ar to saprotot cilvēka prātā balstītu brīvo gribu un atbildīgu rīcību. Tie ir eksistenciālās brīvības meklējumi. Eksistenciālā brīvība ir cilvēka eksistēšanas pamats, kas pati pastāv bezpamata veidā (Un-Grund). Brīvība (ar lielo burtu) ir priekš brīvības, tajā cilvēks ir dots sev pašam. Tā ir iespēja tvert jēgu. Otra līnija ir politiskās brīvības meklējumi, ar to saprotot nacionālo, tautas, sabiedrības atbrīvošanās ideju. Ilgstoši tieši šāda veida - liberty - ideja Latvijā ir spēcīgāka par eksistenciālās brīvības centieniem. Taču nebūt ar liberty, emancipāciju indivīdos tiek izkoptas eksistenciālās brīvības izjūtas. Bieži notiek tieši otrādi: politiskā, ārējā brīiviba aizēno vajadzību būt brīvam - ètiskā, morālā un solidāri atbildīgā nozīmē - arī katram pašam.

Viens no vadmotīviem indivīdu un Latvijas sabiedrības kopumā atbrīvošanā no komunistiskā totalitārisma bija centieni pēc brīvības abās nozīmēs, - gan kā individuālas, gan sociālās un politiskās vērtības. Kop̌̌ 20. gadsimta astoņdesmito gadu otrās puses tie bija centieni:

a) pēc Latvijas valstiskās neatkarības atjaunošanas (šī tēma pārsniedz brīvības centienus un bija nozīmīga starptautiskajā politikā);

b) pēc sociālistiskās plānošanas ekonomikas nomaiṇas ar brīvā tirgus ekonomiku, kurā funkcionētu brīvi ekonomiski subjekti;

c) pēc individuālās atbrīvošanās, ieskaitot runas brīvību, biedrošanās brīvību, ticības brīvību ${ }^{3}$ utt.;

d) pēc pašpietiekamas, izglītotas, labklājībā dzīvojošas personas, kuras eksistences vērtības nodrošinātu sociālā iekārta un starptautiski veiksmīga ekonomika.

Pirmie divi mērķi Latvijā tika sasniegti 1990.-1991. un turpmākajos gados, trešais tika nostiprināts LV Satversmē un cilvēktiesībās, taču ceturtais - brīvas un pilnveidojušās personības jautājums joprojām ir aktuāls 2r. gadsimtā. Tāpēc jāieklausās Fromma filosofijā, kurā viens no vadmotīviem ir jautājums par individuālo brīvību. Jāatzīst, ka Latvijas intelektuālajā domā ir gan kopīgas nostādnes ar Fromma mācību, gan arī atšk,irīgas.

$\bar{E}$. Fromms apraksta dažāda veida vēsturiskos periodus un tiem atbilstošos sociālos raksturus, kas ietekmē cilvēku personiskās dzìves. Viṇa 
redzeslokā vairāk ir indivīds attiecībās ar sabiedrību nekā sociālās kustības, vairāk mācība par raksturiem nekā politisko un ekonomisko tendenču izpēte. Otrā pasaules kara sākumposmā (I94I. g.), publicējot grāmatu „Bēgšana no brīvības”, Fromms paredz, ka cilvēku centieni pēc brīvības var apvērsties uz pretējo pusi, - cilvēks kḷūst nevis brīvs, nevis tiecas uz pašattīstību, savas būtības atrašanu un piepildīšanu, bet gan kḷūst izolēts, vientulšs un tukšs. Brīvība „no” var atnest jaunu verdzību. Filosofa vārdi atbilst arī nākotnes prognozēm, jo 2r. gadsimta patērētājsabiedrībā, pat vairāk nekā pēckara situācijā, brīvība „no” parādās kā važas.

$\bar{E}$. Fromms cilvēka brīvību saskata spontanitātē un radošumā, kam vajadzētu atpestīt no negatīvās brīvības, kas saistīta ar ārēju apspiešanu. Savdabīgi, ka izdevumā „Die Furcht vor der Freiheit” vācu valodā nodaļas nosaukums tiek atveidots Freiheit und Selbstbestimmung, bet krievu valodas tulkojumā „Begstvo ot svobodi” (Moskva, 1990) citādi - Brīvība un spontanitāte (nodal̦as tekstā autors bieži lieto vārdu Spontanität). Frommam pašnoteikšanās ir identa ar spontanitāti. Spontanitāte parādās mīlestībā, darbā, aktivitātēs, kas, vinuaprāt, ir pat svarīgākas nekā to rezultāti. Pozitīva brīvība, pēc Fromma domām, ir personības realizācija. Visiem ideāliem ir jātiecas uz indivīda laimes sasniegšanu. Dzìves jēga ir pati dzìve [das Wirken des Lebenden selbst], apgalvo Fromms, būdams procesa filosofijas ietekmē. Cilvēkam ir jājūt sevi veselumā, jātiecas uz piepildītību, sevis atrašanu. Jāpiezīmē, ka filosofs nebūt skaidri neizvērš, kas ir šis personas kodols, aicinājumi uz to tiekties prevalē pār kodola skaidrojumu. Būt radošam nozīmē aktivitāti, gribu, personas pašapjēgumu veselumā un prāta saistību ar juteklību, emocijām, nenoslīgšanu racionalitātē. Tādējādi Fromms vairāk simpatizē māksliniekiem, maziem bērniem, opozicionāriem nekā racionālām, pārāk log̣iskām personām, kurās saskata iespējamu tieksmi uz destruktīvu vardarbību.

Kā parāda Fromms, brīvības ideja ir Rietumu kultūras gadsimtu gaitā izauklēta, augstākā cilvēciskā vērtỉba. Dzīvei kopumā nav jēgas, ja nepastāv apstākḷi, kuros cilvēks var attīstìt savu spriestspēju, izkopt savu brīvo gribu, ko pavada atbildība par rīcību, un sekmēt solidaritāti.

Brīvība padomju ideologijā bija pseidojēdziens, PSRS laikos lika dziedāt: „Par brīvu un varenu republiksaimi!”, taču reālas politiskas un ekonomiskas brīvības nebija, nerunājot par personisko un vārda brīvību. Jāsecina, ka tieši cilvēku iespējas pilnveidot sevi, atgriezties pie ticības - katoḷu, 
luterticības vai pareizticības - kḷuva par vienu no ierosmēm Trešajai Atmodai un tās nevardarbīgajai pretošanās formai astoṇdesmito gadu beigās. Filosofs un priesteris Guntis Kalme atzīst: „Atmodas procesiem intensificējoties, baznīca, kas ar savu eksistenci lielā mērā iemiesoja un pārstāvēja padomju laika ciešanas un vajāšanas, veidoja nacionālās atjaunotnes garīgo vadību." Brīvības ideja saliedēja cilvēkus visā Baltijā. Ja paraugāmies uz Fromma nostādnēm par diviem brīvības veidiem, tā bija cīṇa galvenokārt par "brivizu no, nevis par”.

Tieši Baltijas Atmodas laika kustība spēja savienot tiekšanos uz Eiropas kultūrā izlolotajām filosofiskajām vērtībām - cilvēka tiesībām, brīvỉbu (liberty), labklājỉbu un solidaritāti savienībā ar nacionālās atbrīvošanās idejām. Tas sniedza politiskajai kustībai līdzsvara izjūtu un politiskajā cīnā nepię̧āva nacionālisma kā vardarbīgas ideolog̣ijas veidošanos vai anarhistisku populismu.

Latvijas atbrīvošanās periods 20. gadsimta astoṇdesmito gadu beigās bija ipaša sociālā rakstura izpausme, kas apvienoja tautības, dažādas paaudzes, dažādu nozaru strādniekus, māksliniekus, pilsētniekus un lauciniekus utt. Ideja var kḷūt par varenu spēku tikai tad, kad tā atbilst noteikta sociāla rakstura cilvēku specifiskām vajadzībām. „Sabiedrības raksturs pārveido ārējās nepieciešamības un šādā veidā virza cilvēciskās enerğijas uz viṇu sabiedrības sistēmā noteiktajiem uzdevumiem."’ Atmodas laikā Latvijā bija šādi uzdevumi, kas palīdzēja brīivibas idejām iemiesoties nevardarbīgajā pretošanās kustībā. Ē. Fromms raksta: „Tas nozīmē: idejas var iegūt varas pilnu spēku tikai tādā mērā, cik tās atbilst īpašām cilvēciskām vajadzībām, kas sabiedrības raksturam parādās kā izšşirirošas."

Nevardarbīgā pretestība astoņdesmito gadu beigās Baltijā kā pareizākais brīvỉbas iegūšanas ceḷ̌s sevi apliecināja dienu no dienas. To noteica pietiekami augsts individualizācijas līmenis, kas l̦āva cilvēkiem izjust sevi kā atsevišķām būtnēm ar savu dzīi un tiesībām. Apgaismība lika saprast: brīiviba ir iespējama, tā vienmēr ir klātesoša iespējamība tajā, ko mēs darām. Brīīiba ir izdevība un cerība, kas jāmeklē un jāizmanto. Ne vēsturei, ne dzīvei nepiemīt kauzalitāte tādā mērā, ka tā būtu iepriekš noteikts nemaināms plāns, viena vienīga patiesība, kā notiks. Cilvēki bija sapratuši modernitātes laikmeta garu, demokrātijas saistîbu ar brīvību, un, kad pavājinājās PSRS laika politiskā kontrole, notikumu attīstību vini arvien drošāk samēroja ar savām iecerēm. 
Nevardarbīgas pretestības jēgu Latvijā pastiprināja centieni tiesiskā ceḷā formulēt savas prasības. Dziesmu melodijas, Baltijas ceḷā stāvošo cilvēku sadošanās rokās [Baltijas cel̦š̀] $]^{7}$ nevis ieroči, bet auseklī̌si pie krūtīm piešķ̄īa politiskajai kustībai vienreizēju garīgu auru, kuras sastāvdaḷa bija arī reliǵiskā atmoda.

\section{PROTESTANTISMS, BRİVĪBA UN RELIĢISKĀ ATMODA LATVIJĀ}

Kapitālisms, kā uzsver Fromms, atbrīvoja indivīdu, bet kapitālisma radītā atsvešināšanās, cilvēka izolācija atkal to sagūstīja, padarot nebrīvu. Fromms analizē protestantisma nozīmi bēgšanā no brīvības. Protestantisms, no vienas puses, parādīja indivīda spēku, bet, no otras puses, uzsvēra glābšanos ticībā un pilnīgā paklausībā Dievam. Viņa interpretācijā Luters atbrīvoja cilvēkus no ticības baznīcai, bet nodeva vēl tirāniskākas varas Dieva - rokās, kas prasa bezierunu paklausību un paredz individuālās personības nonivilēšanu. Fromms uz luterticību skatās skarbi: „Lutera „ticība” bija pārliecība, ka vajag pakḷauties pašuzdevuma noteikumiem, tāds risinājums, kam bija daudz līdzības ar principu par indivīdu pilnīgu pakḷaušanu valstij un „fíreram”. ${ }^{8}$

Latvijas gadījumā 2o. gadsimta astoṇdesmito gadu otrajā pusē reliǵiskajā atmodā turpretī nebija spēcīgi izteiktu fïrerisma, autoritārisma vai destruktīvu personību, kuras Fromms saskata pirmāmkārtām protestantismā. Drīzāk otrādi - brīvības ideja bija arī ticības brīvības ideja. Atmodas laikos luterticỉba nāca ar pozitīvu vēsti, kuras centrā bija indivīda morāle, dal̦a vācbaltu mācītāju sekmēja dzimtbūšanā nospiestos latviešu zemniekus izglītoties, tiekties uz personisko attīstību un brīivibu. ${ }^{9}$

Tas liek izdarīt secinājumus, ka vēstures gaitā reliğiskās konfesijas attiecībā pret atbrīvošanās ideju var spēlēt visdažādākās lomas - būt reakcionāras un parādīt cilvēka absolūto atkarību no pasaules un Dieva spēka, taču var būt arī atbrīvošanos veicinošas, kā Baltijas gadījumā 1987.-1991. gadā. Jāmin arī katoḷu pāvesta Jān,a Pāvila II morāli iedvesmojošā loma, ko veicināja viņa vizīte Baltijas valstīs - arī Latvijā 1993. gadā. Jānis Pāvils II atzina personas tiecību uz brīvību ${ }^{10}$ par vienu no galvenajiem garīgās dzīves vadmotīviem. 1993. gadā pāvests, uzrunājot Latvijas inteliǵenci Latvijas Universitātes Lielajā aulā, uzsvēra to, ka ir dziḷāk jāizprot individuālās atbildības saistîba ar 
iegūto politisko brīvību. Tas nozīmē tiekties ne tikai pēc individuālās brīvības, bet arī pēc atbildīgas sabiedriskās brīvības. Pāvests savā uzrunā norādīja, ka pārmain,as Latvijas sabiedrībā, ekonomiskajā situācijā un morāles jomā ir iespējamas tikai tad, ja mainīsies katrs cilvēks. Šì atziņa Latvijā ir aktuāla lìdz pat šim laikam.

Jānis Pāvils II ar konceptuālu skaidrību saistīja nacistisko un komunistisko totalitārismu, uzsverot, ka abas minētās sistēmas 20. gadsimtā radīja vienlīdz lielu l̦aunumu. ${ }^{11}$ Tām abām raksturīga cilvēkam naidīga ideologija un tās vainojamas līdzvērtīgos noziegumos pret cilvēci. Viņš nemēǵnināja attaisnot Otrā pasaules kara uzvarētāju noziegumus, kā tas nereti noticis pēckara perioda politiskajā dzīvē. Otrā pasaules kara uzvarētājas nācijas, piemēram, Krievija, veicot vēsturisko analīzi, nereti mēgeina nošķirt savus kara noziegumus no nacisma ḷaundarībām un cenšas noklusēt staḷinisma zvērības. Tieši tā - saistot nacismu un staļinismu, totalitārisma spilgtākos pārstāvjus, - būtu jāuztver posts, ko cilvēcei nodarīja abi 20. gadsimtā valdošie totalitārie režīmi, kuri iznīcināja miljoniem cilvēku un kuru nodarījumi nav pilnīgi nožēloti. Tāpēc Jāṇa Pāvila II religiski êtiskā pozīcija ir globāli svarīga, lai apturētu bēgšanu no brīvības un aicinātu pārvarēt paklausību militāri politizētiem tirāniem. Tai ir pasaulvēsturiska, morāli politiska un izskaidrojoša nozīme.

Savu lomu relig̣ijas pozitīvajā līdzdalībā Latvijā spēlēja arī tas, ka padomju ideologija bija caur un caur ateistiska un pat vardarbīga attiecībā pret baznīcu un ticīgajiem, mēginot reliǵgisko ticību aizstāt ar ideologisko ticību. Valdīja brīvības alkas, nevis paklausība autoritāram vadonim un grimšana šaubu bezdiben,os. Luterticīgie mācītāji, to skaitā Modris Plāte, Juris Rubenis, Jānis Rožkalns, Jānis Vanags u.c., kā arī vecās paaudzes mācītāji Roberts Feldmanis, Roberts Akmentiņš, arhibīskaps Kārlis Gailīits kḷuva par cilvēka atbrīvošanās idejas nesējiem. Jaunie luterāṇu mācītāji I987. gadā izveidoja kustību „Atdzimšana un atjaunošanās”, kuras centrā lika demokrātijas, kristīgās cilvēkmīlestības un nesatricināmas ticības postulātus.

20. gadsimta otrajā pusē lielākais vairums cilvēku Latvijā nepieṇēma padomju režīma piedāvāto relig̣iskās ticības nomaiņu ar komunistisko propagandu, savā attieksmē paliekot indiferenti, ticību meklējoši vai slēpti ticīgie. Pārmaiṇu brīdī tas l̦āva protestantismam ${ }^{12}$ parādīties kā morāli, kulturāli un sabiedriski atbrīvojošam spēkam. 
BRĪVĪBA: LIRISKĀS UN SADOMAZOHISTISKĀS PERSONĪBAS

Ē. Fromma sniegtā mācība par raksturiem dod iespēju šajā dimensijā pārdomāt arī Latvijas pārmaiṇu vadītāju tēlus. Starp Tautas frontes pirmajiem, tautā populārajiem vadītājiem nebija tādu tipisku sadomazohistisku personību, kādas tik spilgti analizējis Fromms (Hitlers, Himlers, Staļins). Drīzāk otrādi - Daiña Īvāna kā Tautas frontes pirmā vadītāja tēls bija maksimāli romantizēts, lauku ganiņa pelēkajos kamzolī̌̌os tērpts, ar vienkāršiem vārdiem izteikts un komunikatīvas labvēlïbas pārpilns. Tas parādīja iespēju pārmaiṇu laikos dominēt arī iracionāli savdabīgām, liriskām personām, ja to vārdi un rīcība saskanēja ar pārmaiņas alkstošo Latvijas sociālo raksturu izvirzìt mītiskus ideālus.

Par sadomazohistiem vai agresīviem narcisiem nevar nosaukt arī nacionāli ievirzītos Latvijas Komunistiskās partijas vadītājus kā, piemēram, Anatoliju Gorbunovu un Jāni Vagri. ${ }^{13}$ Viṇu rakstura iezīmes sakrita ar pārmaiṇas gaidošo sabiedrības raksturu: piesardzība, nogaidīšana, paḳ̣aušanās straumei, atturība pret izvirzīto simbolu (brīvība, valstiskuma atjaunošana) konkretizāciju telpā un laikā. Viṇi vadīja procesus savas kompetences un varas iespēju robežās, drīzāk atturīgi nekā varaskāri. Turklāt politiskā vara slīdēja viņiem ārā no rokām un tās noturēšanai PSRS brūkošajā sistēmā bija arvien mazāk instrumentu, izṇemot iespēju lietot militāro un speciālo dienestu vardarbību pret civiliedzīvotājiem. Sadomazohistiskas personas to būtu izmantojušas, bet Latvijā tādu nebija pārāk (jeb pietiekami) daudz, un tās nespēja iegūt harismātisku varu, ne arī tiešu militāru atbalstu no PSRS vadibas.

Militārās vardarbības eskalācijas trūkums I988.-I99I. gadā Latvijā nenozīmē, ka šeit nebūtu radušās autoritāras personas, kas vēlāk izmantoja privatizācijas laiku personiskā labuma gūšanai, ka pēc Atmodas laika nebūtu sākusi nostiprināties reliǵiju autoritārā vara, ka patērētāju sabiedrības iespaidā nesāktu vairoties „tukšas” individualitātes, ka nereti mīlestība negūtu kroplīgas formas, kurā valda izdevīgums utt.

$\overline{\mathrm{E}}$. Fromms ir izdarījis nozīmīgus secinājumus par autoritārisma emocionālajām saknēm: sadomazohistiskai personai mīlestība nav savstarpēja savienība uz līdztiesības pamatiem, bet simbiotiska atkarība; pašuzupurēšanās nav savas psihiskās un morālās būtības apliecinājums, bet personas 
pakḷaušanās kam augstākam; atšķirības starp cilvēkiem nenozīmē individualitāšu dažādību uz līdztiesības pamata, bet dažādu varu; taisnīgums nenozīmē iedzimtu un neatņemamu cilvēka tiesỉbu realizāciju, bet likumu, ka katrs saṇems pēc nopelniem; vīrišķỉba nenozīmē savas individualitātes augstāko apliecinājumu pret ārēju spēku, bet gatavību pakḷauties un ciest.

Vardarbīgākus risinājumus astoņdesmito gadu beigās Latvijā vēlējās Tautas frontei pretstāvošās organizācijas - Interfrontes vadība - Igors Lopatins, Aleksejs Aleksejevs un Tatjana Ždanoka, uz to kūdīja arī padomju ortodoksālie ideologi Maskavā, piemēram, 80 . gadu beigās TV bieži redzamais Viktors Alksnis. Par personības iezīmju kopumu Fromma izstrādātā modeḷa veidā būtu interesants pētijums par Alfrēdu Rubiku ${ }^{14}$ 8०. gadu beigās Rīgas Domes priekšsēdētāju, Latvijas PSR Komunistiskās partijas pirmo sekretāru I99I. gadā, vienu no ortodoksālajiem marksistiem, kura darbībā savienojās saimnieciskums ar uzticību padomju režīmam un komunistiskajai ideologijai. Ir ziņas, ka Rubiks sastādijis Tautas frontes nogalināmo un cietumos iemetamo aktīvistu sarakstus. ${ }^{15} \bar{E}$. Fromma grāmatā „Cilvēka destruktivitātes anatomija” izstrādātais raksturu algoritms saistībā ar vardarbības un paštaisnīguma tieksmēm var būt lielisks modelis, kā aplūkot personību lomu. Tas vēl nav izdarīts, taču šādi pētījumi pavērtu lielāku skaidrību uz personību lomu Latvijas vēsturē.

Neskatoties uz ortodoksālo komunistu un militāristu destruktīvo rīcību un vardarbības eskalācijas iespējām, brīvības atgūšanas ceḷ̌s Latvijā tomēr rezumējās kā nevardarbīgā pretošanās un politiskās, ekonomiskās brīvības un cilvēktiesību atgūšana I990.-I99I. gadā. Tiesiskajā ceḷā nozīmīgs solis bija 1990. gada 4. maija Deklarācija, kas Tautas frontes romantiski nacionālo ievirzi pavērsa starptautiski nozīmīgā, juridiski pārdomātā, politiski izaicinošā aktā par Latvijas neatkarības atjaunošanu un brīvību nodrošināšanu. ${ }^{16}$

\section{BĒGŠANA NO IEGŪTĀS BRĪVĪBAS}

Ē. Fromms savos darbos parāda, ka Eiropas kultūras (vārda plašā nozìmē) attīstība iet uz brīvības iegūšanu, bet reizē ar to pastiprinās nebrīvības spaidi; ja cilvēks vairs nav pakḷauts ārējiem politiskiem, juridiskiem spaidiem, tad iekšêji viņš vai viṇa sāk pakḷauties vienveidības, iztukšotības 
un atsvešinātības procesiem. Grāmatā „Cilvēka sirds” Fromms raksturo brīvību kā izšķiršanās spēju. Cilvēkam, atškịirībā no dzīvniekiem, ir iespēja dzīvot daudz plašākā pasaulē, izvēlēties starp iespējām, starp labu un l̦aunu, piepildīt savas garīgās vēlmes. Brīvība vienmēr IR. Fromms raksta: „Brīiviba nav kāds konstants atribūts, kas mums ir vai nav [piemītošs]. Brīivibu rod nevis tāpat kā iegūst kādu lietu, brīvība ir vārds, abstrakts jēdziens. Tas sniedz tikai vienu realitāti: sevis atbrīvošanas aktu izšķiršanās procesā. Šajā procesā mūsu spējas izvēelēties līmeni variējas katrā aktā, katrā mūsu dzīves praksē." 17

Atmodas laikos Latvijas cilvēkiem bija izvēle vai nu atbalstīt komunistiskās iekārtas - totalitārā režīma turpināšanos vai atbrīvošanos no totalitārisma cerībā uz personiskajām un politiskajām brīiībām. Vēsturiskais laiks bija tāds, ka, izdarot šo izvēli, nācās sekot notikumu gaitai. Savā ziṇā te varēja saskatīt arī citu brīvības koncepciju, t.i., nevis izvēles situāciju, bet pamatizvēli, kas nozīmē - „attīrīt dzīves laukumu” un sākt visu no jauna atjaunot valsti, atjaunot ekonomiku, atjaunot sociālās struktūras, atjaunot dzīves vērtības.

Raugoties uz Eiropas dramatisko vēsturi, rodas iespaids, ka eiropiešus allaž pavadījušas izjūtas: apspiest un atbrīvot. Ne velti tādi jēdzieni kā „spēks”, „brīvība”, „uzvara”, „vara” ir eiropiešu leksikas centrā. Ja prāta varas laikmetā (klasiskais laikmets) izglītības ievirze bija apstādināt vēlmju ražošanas mašīnu, jūtas pakḷaut prātam, spontanitāti (to aizstāv Fromms) pakḷaut refleksijai, tad mūsdienās pastāv tendence intensificēt vēlmes, tās uzskatīt par cilvēka brīvības apliecinājumu. Valda lozungs: ražosim un apliecināsim vēlmes! Cilvēks, atrazdamies visuresošas varas valgos, nonāk situācijā, kurā sāk alkt, lai būtu brìvība no brīin̄bas. Taču piemēri no dzīves liecina, ka pretējā polā brīivibai atrodas tikai nebrīvība, nevis kāda augstāka brīvība. Mūsdienās vairs nerunā, ka tev ir dvēsele un to vajag glābt, bet gan - ka tev ir ķermenis un jāmācās to baudīt. Tev ir libido - un jāzina, kā to izlietot.

$\bar{E}$. Fromms sniedz interesantu vērojumu, ka demokrātijas nostiprināšanai ir vajadzīgs arvien vairāk individuālisma, ar to saprotot attīstīto individuālismu, nevis kailu egoismu. Viņš raksta: „Mūsdienu kultūras un politiskā krīze sakṇojas nevis tur, ka mūsu pasaulē būtu par daudz individuālisma, bet rodas tādējādi, ka tas, ko mēs esam uzskatījuši par individuālismu un bieži turpinām uzskatīt, ir kḷuvis par tukšu čaumalu”. ${ }^{18} \mathrm{Kā}$ 
redzams, Fromms ir palicis uzticīgs liberālisma un apgaismības vērtībām, cerot uz personības pašizaugsmi.

Tomēr pēc Latvijas valsts neatkarības atjaunošanas pamazām garīgā solidaritāte zūd, cilvēku tiekšanās uz brīvību kā personisko vērtību sarūk un sākās laiks, kurā ne mazums vardarbības pret cilvēkiem tiek realizēts ar egoisma, liekulības un naudas varu. Brīvība mūsdienās ir pakḷauta tik daudzām interpretācijām, ka sāk kḷūt par tukšu, ideologiski nolietotu čaulu atmiņu ietērpšanai par klasiskajiem laikiem cilvēka attīstībā. Jirgens Hābermāss runā par mūsdienu publiskās telpas kolonizāciju un iluzoro atvērtību, kas aiz šķietamās vārda brīivibas slēpj manipulāciju ar sabiedrību un spekulācijas ap informāciju. Publiskajā telpā ir notikušas strukturālas transformācijas. ${ }^{19}$ Mūsdienu publiskā telpa vairs nav atvērta visiem un nav neatkarīga. Tā ir komercializējusies, naudaskāra un privatizēta, nesekmējot brīvas debates starp pilson,iem. Pastāv spēles laukums, kurā tiek piel̦auta kritika, bet nepastāv laukums, kurā pietiekami tiktu kopta personības brīvība. To pašu var teikt par lielu daļu mūsdienu Latvijas medijiem. ${ }^{20}$

Vai ideolog̣iju kritika dod cilvēkam brīvību? Atbilde saistās ar nostādni: cik dziḷa līmeņa brīvību? Totalitārās valstis aizliedz cilvēku brīvu pārvietošanos, apklusina presi, rada bailes, dibina izsekošanas dienestus utt. Atbrīvošanās no šādas valsts spaidiem ir pirmā līmeņa - politiskās brīvības iegūšana, ko apliecina iespēja realizēt savas cilvēktiesības. Taču dziḷākā līmen,a brīvību cilvēks var dot tikai sev pats, jo tās būtība ir vajadzībā būt brīvam. Ja nav šîs vajadzības, nebūs brīvības. Mišels Fuko ir pārliecināts: „Cilvēka brīvību (liberty) nekad neiedos institūcijas un likumi, kas tiek radīti, lai to garantētu. Tāpēc lielākā dal̦a šo institūciju ir pilnīgi spèjīga pagriezties uz otru pusi. Nevis tāpēc, ka tās būtu divdomīgas, bet vienkārši tāpēc, ka „brīvību” vajag praktizēt. [..] Es domāju, ka lietu struktūra nekad nevar garantēt brīvības praktizēšanu. Brīvības garants ir brīvïba." ${ }^{21}$

Vērtības pārvietojas: brīiība, kas sengrieķu kultūrā - polisu laikmetā - raksturoja politisko sfēru, no tās laika gaitā "pārcēlās” uz privāto sfēru, kḷūdama par cita veida brīvību. Mūsdienās tiek sajaukts publiskais ar privāto, dzīve vairs neparedz indivīda brīvu rīcību kā pretmetu publiskajai sfērai. Valda iekl̦aušanās, nevis atbrīvošanās taktika. Brīvas rīcības vietā nāk uzvedìba, kas tiek veidota, iemācīta, standartizēta. Tas rada Fromma aprakstīto bēgšanu no brīvības. 


\section{KĀ RUNĀ UN DOMĀ PAR BRĪVĪBU?}

Liela ideologiska slodze Eiropas vēsturē ir vārdam „atbrīvošana”, spekulējot uz sakni „brīv” un radot asociācijas ar brīvību. Latvijas politiskā vēsture ir pilna ar stāstiem par „atbrīvotājiem”: Latvijas zemi 1940. gadā esot ,atbrīvojis” padomju karaspēks, no tā atkal ,atbrīvojusi” vācu nacistiskā armija, no tās atkal „atbrīvojusi” PSRS armija. Bet Stalina vara „atbrīvojusi” visus apspiestos.

Politizētai valodai piemīt tā ìpatnība, ka pat pretējās pusēs karojošie izmanto vienādus vārdus, aizsedzoties ar kādu vispārcilvēcisku vērtību. Mūsdienu dzīvesveids ne tik daudz palielina individuālās brīvības iespējas, cik tās pārdala - kam tiek, kam ne. Par brīvību vairs netiek sapņots tā, kā to darīja, veidojot nacionālās valstis vai koloniālās atbrīvošanās laikā. Brīvība ir apzīmējums, kas lielākoties tiek lietots kā īpašỉbas vārds (brīvs, nebrīvs), nevis ideāls vai utopija. Reklamējot preces, tiek uzsvērta brīvība kā iepirkšanās brīvība. Brīvība visādās versijās: brīvs izvēlēties zobārstu, brīvs seksā, brīvs apgēerbs, brīva runa, brīvpusdienas utt. Brīvība ir sasniegta iespēju daudzveidībā. Ierobežojumi, personas datu uzskaite, datu kontrole un pilnīgi nevajadzīgu ziņu vākšana tiek uztverta kā laikmeta nepieciešamība. Pilnīga personas brīvība ir neticama, jo personu nemitīgi saista kādi ierobežojumi, lielākoties tie ir birokrātiski, nevis valstiski nozīmīgi vai ierobežojumi drošības dēl,. Iespējas izvēlēties, ko radījusi mūsdienu dzīve, rada vilinājumu cilvēkam kḷūt par neko, anybody. Dzīvojot brīvībā, izrādās, ka grūtākais ir noteikt prioritātes. Tagad vajadzību radīšana aizṇem normatīvās regulācijas vietu. Patērētājsabiedrība cilvēkiem iedveš viṇu vajadzības. Ir pastāvīga nesaskaņa starp „es gribu” un „es varu”. Šì divu izjūtu pretruna tāpat kā agrāk ir sociāls fenomens, taču katrs ar to tagad sastopas kā ar personīgu problēmu. Mēs esam brīvi, lai baudītu brīvību, bet neesam brīvi no tās radītajām sekām - tur brīvība nesniedzas. Tirgus uztur dzīvu šo divkosību un tā savukārt - tirgu. Cilvēki lielākā vai mazākā mērā uztver pasauli kā nenoteiktu un nedrošu, pilnu ar riskiem.

Rakstnieks Česlavs Milošs izsaka savu vērojumu, ka „Rietumu cilvēki cieš... Brīvība kḷūst par nastu. Neviens secinājums nav obligāts. Var būt tā, bet var būt arī citādi. Un te rodas pastāvīga diskomforta sajūta.” Liekas, ka cilvēkam ir lielāka brīvība, taču tā nav, jo brīvībai vajadzīga noteiktība un 
robežas. Vajadzīgs vēlmju ierobežojums un dzīves saprātīga virzība. Ja brīiviba ir visur - kā migla vai tvaiks - it kā visaptveroša un reizē neskaidra, tad tā dzīvi pārvērš nesapratnē. Apmulsums, maldīšanās un neuzticības krīze nav brīvības pazīmes. Brīvība ir patiesībā, skaidrībā, mērḳ̂̄ un solidārā uzticībā. Brīiviba ir drosme pretstāvēt pūlim, mediju manipulācijām, palikt reizēm pat vienam un vien̄igam, lai apliecinātu neatkarīgu domu.

Iespējams, ka Latvijas tauta 20. gadsimta astoṇdesmito gadu beigās un devin, desmito gadu sākumā, tā saucamās „Trešās atmodas” laikā bija brīvāka un drošāka nekā tagad, pēc divdesmit un vairāk kapitālisma gadiem. Visu šo laiku ir pietrūcis tā vadmotīva un prakses, ko dod kultūras vērtības, izglītỉba un morālās vērtības, kas iedibina cilvēkos iekšējo brīvību savienībā ar atbildību. Brīuība par vēl nav ieguvusi savu apliecinājumu, tā varēs uzplaukt tikai tad, kad rimsies modernitātes laika kultivētā vardarbība.

\section{IZDZİVOŠANAS STRATĒĢIJAS UN VALODA}

Ē. Fromms savā filosofijā nav speciāli pētījis tēmu par nacionālo valodu kā izdzīvošanas stratēgiju. Strādājot jaunībā vācu valodas vidē, vēlāk angḷu valodā, viņš piederēja pie lielajām nācijām, kurām valodas pastāvēšana nav apdraudētības faktors, jo valodas esamība ir pašsaprotama lieta. 1934. gadā Fromms publicēja rakstu „Mātes tiesību teorijas sociālpsihologiskāā nozīme”, vēlākajos darbos pievērsās jautājumiem par lietvārdu lietošanas prioritāti pār darbības vārdiem, kas saistāma ar lietu kulta nostiprināšanos, aplūkoja sapṇu valodu, tās simbolismu, izteiksmes formu daudzveidību u.c. Grāmatā „Viṇpus ilūziju važām. Mana sastapšanās ar Marksu un Freidu” Fromms parāda, kā valoda darbojas sabiedriski noteikta filtra lomā. Filtrs iespiežas apziñā, nosakot, ko var pateikt, ko ne; kas ir izsakāms, kas nav; kas ir domājams un izjūtams, kas paliek neapzinātā dzīlēs. Viṇaprāt, daudziem ķermeniskajiem pārdzīvojumiem nav atbilstošu vārdu. Arī valodas atškiras pēc to uzmanības pret jutekliskajiem pārdzīvojumiem. ${ }^{22}$ Ja Fromms būtu zinājis latviešu valodu, iespējams, būtu pārsteigts, cik tā bagāta tieši ar emocionālo pārdzīvojumu un emocionāli iekrāsotu darbību apzīmējumiem. Taču latviski joprojām nepietiek logiski darināto abstrakciju, tādēḷ svarīgi filosofiskās klasikas tulkojumi ar jēdzienu jaunradi, kuros parādās smalki diferencētas loğiskās nianses. 
Valodai kā izdzīvošanas vērtībai ir cits rakurss nekā valodai kā izteiksmes līdzeklim. Mazu tautu valodas var ātri vien nonākt izmirstošo valodu sarakstā, ja valodai nav sociāli ekonomiskās vērtības un tā netiek politiski un valstiski atbalstīta. ${ }^{23}$ 1980. gadu beigās Atmodas līderi pārn,ēma jaunlatviešu I9. gadsimta pozīcijas, atzīstot, ka tauta - tā ir valoda un konstatēja latviešu valodas apdraudētību. Latviešu valoda, baltu mitologijas zīmes kḷuva par atbrīvošanās kustības simboliem. Latviešu valodas nostiprināšanas vajadzība kā tautas izdzīvošanas stratēgija tika pretstatīta pārkrievošanas draudiem, kas pastāvēja PSRS laikā. ${ }^{24}$

Padomju laikā tautu nacionālās valodas tika piel̦autas sadzīvē, taču visās nopietnākajās nišās - politikā, tieslietās, zinātnēe, starptautiskajās attiecībās u.c. tās tika aizstātas ar krievu valodu. Tādējādi valodas pastāvēšana bija apdraudēta, jo valodas lietojums tikai sadzīvē un kultūras priekšnesumos nenodrošina tās pilnvērtīgu eksistenci. Lai arī padomju totalitārisms cilvēkos iedzina bailes un mazvērtības sajūtu, tomēr 20 . gadsimta 60. un 70. gados milzu metienos iznāca humānistiski ievirzītā latviešu literatūra, radās disidentiskās kustības un savi nacionālie varoṇi. Pretošanās gars tika saistīts ar rūpēm par latviešu valodas (citās Baltijas valstīs attiecīgi igauṇu un lietuviešu valoda) sargāšanu un attīstību, no sadzīves sfēras tās pārnesot uz politiku, tieslietām, augstskolām, zinātni, tirdzniecību utt. Atbrīvošanās politika gāja roku rokā ar valodas politiku. Valsts valodas likums, kas pieņemts 1999. gadā, ir novērsis latviešu valodas apdraudētību pašu valstī, kaut gan ik pa brīdim parādās politiski motivēti ierosinājumi, kuru realizācija vājinātu latviešu valodas nozīmi (piemēram, 2012. gadā referendums par krievu valodu kā otru valsts valodu, izglītības sistēmas pārmaiṇu ieceres Reformu partijā, kas ḷautu visām augstskolām apmācību veikt krievu valodā utt.).

2r. gadsimts Latvijā ir sācies kā rūpju pilns laiks, neraugoties uz pozitīvo bilanci, kas gūta 20. gadsimta beigās, proti, ir iegūta valstiskā suverenitāte, cilvēktiesības un politiskās brīvības, latviešu valodai ir nostiprināta izdzìvošanas stratēgiija. Taču parādījušās citas briesmas, ko trāpīgi pirms pusgadsimta jau saredzēja Fromms: bēgšana no iegūtās brīvības, sekls individuālisms, patērētājsabiedrības dzīšanās pēc vēlmju piepildījuma, morāles zudums, globāls terorisms, vardarbības attēlojums medijos un tā kaitnieciskā ietekme uz psihi, kā arī sadomazohistisku un psihopātisku 
personu nokḷūšana pie varas demokrātijas vājuma dēḷ. Ė. Fromma raksti ir kā dzīves skola, kas palīdz izvērtēt notiekošo analītiskās sociālpsihologiijas gaismā un ir derīgi mūsdienu Latvijas problēmu risinājumos.

\section{Vēres}

I Серия „История сталинизма”. Dokumentu, monogräfju, diskusiju katalogs. http:// www.rosspen.su/ru/catalog/.detail/id/56/limit/0.20.1../skatits 5.01.20I4.

2 http://o2varvara.wordpress.com/2014/03/13/two-thirds-of-russians-believe-crimeaand-the-eastern-ukraine-are-essentially-russian-territory-russia-has-the-right-to-usemilitary-force-to-protect-their-people/ Skatīts I3.03.20I4.

3 To apliecināja tas, ka viens no pirmajiem LR AP juridiskajiem aktiem līdzās 4. maija Deklarācijai bija pievienošanās ANO Cilvēktiesību Deklarācijai un citiem pasaules nozīmīgākajiem cilvēktiesību aktiem.

4 Kalme G. Tautas nacionālās un religisiskās identitātes apzināšanās loma neatkarības atgūšanā. Nevardarbīgās pretošanās loma Latvijas neatkarības atjaunošanā. Rīga: LZA, 2008, 223. lpp.

5 Fromm E. Die Furcht vor der Freiheit. Frankfurt am Main: Europäische Verlagsanstalt, 1978 , S. 276.

6 Turpat, S. 274.

7 Baltijas brivības ceľ̦s (The Baltic Road to Freedom). / Sast. J. Škapars. Rìga: Zelta grauds, 2005.

8 Fromm E. Die Furcht vor der Freiheit, S. 87.

9 Sk.: Straube G. Latvijas brälu draudzes diärijs (jaunākais noraksts) jeb hernhūtiešu brälu draudzes vèsture Latvijā. Rīga: NIMS, 2000, 317 lpp.

Io Skat. tuvāk Jāṇa Pāvila II, laicīgajā vārdā Karols Vojtila, filosofisko grāmatu „Persona, kas darbojas" (The acting Person) (Analecta Husserliana, vol. Io, Kluwer acad. publishers, 1978), kurā viņ̌̌ sasaista personas dzīves pilnvērtīgu realizāciju ar brīvību, sadarbību un atbildību.

II Svarīgi atzīmēt soḷus, ko 2009. g. 2. aprīlī spēra Eiropas Savienības parlaments (tas bija arī Latvijas deputātu nopelns), pien̨emot deklarāciju Declaration of the European Parliament "European conscience and totalitarianism”, kurā nosodīts gan staḷinisms, gan nacisms un 23. augusts Eiropas Savienībā pasludināts par totalitārisma upuru piemiñas dienu „European Day of Remembrance for Victims of Stalinism and Nazism, in order to preserve the memory of the victims of mass deportations and exterminations".

I2 To pašu var attiecināt arī uz katolicismu Latvijā un no Baltijas valstīm - ìpaši Lietuvā, taču jautājumu par protestantismu aplūkoju tādēḷ, ka tieši tā izvērtējumu saistībā ar bēgšanu no brīvības devis Fromms. Par situāciju Latvijas vēsturē 20. gs. otrajā pusē sk. arì: Strods H. Resistance by the Churches. Blūzma V., Jundzis T., Riekstiňš J., Sharp G., Strods H. Regaining Independence: Non-violent Resistance in Latvia. I945-Iggr. Riga: Latvian Academy of Sciences, 2008, pp. 95-IOI. 
I3 Interesantas ziṇas sniedz avīzē Latvijas Jaunatne I991. gada Io. decembrī (nr. I86) publicētais raksts „Piln̄igi slepeni, bet tie nav KGB saraksti”, kurā sniegts Krievijas specdienestu sagatavots raksturojums par vadošajiem Latvijas PSR politiskajiem darbiniekiem, tas bijis domāts kā slepens materiāls PSKP CK Politbiroja locekḷa V. Medvedjeva vizìtes sagatavošanai. A. Gorbunovs tajā raksturots kā reālais līderis, kas iet LTF pavadā, pakḷaujas Rakstnieku savienības vadībai, neḷauj vest pie prāta masu informācijas līdzekḷus. J. Vagris savukārt raksturots kā netalantīgs orators, ieņem attaisnošanās un nogaidošu pozīciju. A. Rubiks raksturots īsi kā karotājs pret Latvijas Tautas fronti. Savdabīgi, ka pie šiem karotājiem „pret” pieskaitīts arī toreizējais LZA Vēstures institūta direktors I. Ronis.

http://www.barikadopedija.lv/raksti/355102, skatīts 10.02.2014.

I4 A. Rubiks pēc Latvijas neatkarības atjaunošanas nonāca cietumā par PSRS augusta puča atbalstīšanu un demokrātiskās varas Latvijā gāšanas mēǵinājumu. Bija ievēlēts par Eiropas parlamenta deputātu no Latvijas. Sk.: www.europarl.europa.eu/meps/en/g6988/ ALFREDS_RUBIKS.html

Is Šādu informāciju pauda prese.

http://www.la.lv/vini-bija-mutuli-ieksa-ar-jaunu-filmu-svin-tautas-frontes-25-jubileju/ Taču dokumentu krājumos tādi saraksti nav publicēti. Pēc Maskavas puča sagrāves divas dienas LKP CK ēkā esot dedzinājuši dokumentus, lai slēptu vardarbīgos nodomus. Viens no puišiem, kam bijis uzdevums arestēt Rubiku, teicis tagadējam LV Saeimas deputātam Atim Lejinam par 200 nošaujamo un 400 uz Baltkrievijas nometnēm nosūtāmo sarakstiem, ja virsroku būtu n,ēmuši pučisti. Šie saraksti tagad esot pazuduši.

I6 Deklarācijas nozīme analizēta grāmatā 4. maijs: Rakstu, atmiņu un dokumentu krājums par neatkarības deklarāciju. Rīga: Fonds Latvijas Vēsture, 2000.

I7 Fromma aforismi:. Sk.: interneta avotu Erich Fromm, El Corazon del Hombre: Su Potencia Para el Bien y Para el Mal;

http://www.goodreads.com/work/quotes/1138362-the-heart-of-man-its-genius-forgood-and-evil

I8 Fromm E. Die Furcht vor der Freiheit, S. 263.

I9 Habermas J. The Structural Transformation of the Public Space. The MIT press, I991, pp. 27-31.

20 Rožukalne A. Kam pieder Latvijas mediji? Rīga: Zinātne, 2013.

2I Foucault M. Space, Power and Knowledge. The Cultural Studies Reader. Ed. by Simon During. Routledge, 2003 , p. 135.

22 Fromm E. Jenseits der Illusionen. Die Bedeutung von Marx und Freud. Frankfurt am Main: Deutsche Verlagsanstalt, 1981, S. ir8.

23 Par valodu konkurences situāciju un tās bīstamību latviešu valodai Latvijā skaidro Ina Druviete rakstā „Latviešu valoda pēc neatkarības atgūšanas” izdevuma „Latvieši un Latvija” 3. sējumā „Atjaunotā Latvijas valsts” (Rīga: LZA, 2013, 243.-25ı. lpp.).

24 Riekstiņš J. Par latviešu valodu. Pret rusifikāciju. Nevardarbīgā pretošanās: Latvijas pieredze: rakstu, dokumentu un atminu kräjums, veltīts Barikāžu atceres Is. gadadienai. Rīga: LZA, 2006, 34.-42. lpp. 


\section{Solveiga Krūmina-Kon,kova}

\section{Ėrihs Fromms, Rūdolfs Šteiners un „gara zinātnes" Latvijā 20. gadsimta sākumā}

Ievadā vispirms jāpaskaidro, ka rakstā vārdu salikums „gara zinātne” tiek lietots divējādā nozīmē. Pirmkārt, te domāta "gara zinātne” tādā nozìmē kā to lietoja antroposofijas pamatlicējs Rūdolfs Šteiners, tas ir, „gara zinātne" ir zinātne, kas ḷauj cilvēkam iegūt drošticamas ezotēriskas zināšanas („zināšanas par garīgo spēku darbību cilvēkā, uz Zemes un kosmosā”). ${ }^{1}$ Viens no R. Šteinera mācības mērķiem bija zinātnes, mākslas un reliğijas atkalapvienošana. Tāpēc, pēc viņa domām, gara zinātnes uzdevums ir aplūkot cilvēku kā mikrokosmu un tādējādi l̦aut viņam, izzinot sevi, iepazìt pasauli un, izzinot pasauli, saprast pašam sevi. Otrkārt, ar "gara zinātni” Latvijā domāta vairāku konkrētu garīgu biedrību darbība 20. gadsimta sākumā, proti, Latvijas Parapsihologijas biedrības darbība no 1924. līdz 1928. gadam, Latvijas Gara Zinātņu biedrības darbība no 1930. līdz 1936. gadam un Kosmosofijas zinātņu veicināšanas biedrības Latvijā darbība no 1933. līdz 1936. gadam.

Pie šo biedrību darbības un idejām mēs atgriezīsimies nedaudz vēlāk, bet vispirms mēgināsim atbildēt uz jautājumu, vai vispār ir iespējams atrast tiešu saikni starp Ērihu Frommu, Rūdolfu Šteineru un tikko nosauktajām biedrībām?

Nē, šādu tiešu saistību mēs neatradīsim. Tāpēc droši vien raksta nosaukumu vajadzētu papildināt ar vārdiem: satikšanās, kuras nav bijis. R. Šteinera aktīvās darbības laiks noslēdzas i925. gadā Šveicē. Kaut arī viņš aktīvi lasa 
lekcijas Vācijā un ir piln̄̄gi iespējams, ka kādu no tām varētu būt apmeklējis arī jaunais Fromms, par to tiešu norāžu mūsu rīcībā nav. Tiesa, tūlìt pat jāatzīmē, ka Šteinera mācība 20.-30. gadu mijā bija gana populāra Vācijā un droši vien arī Frankfurtē pie Mainas un Heidelbergā laikā, kad turienes universitātēs studē Ẽrihs Fromms, ${ }^{2}$ tāpēc par R. Šteineru viņš noteikti vismaz kaut ko bija dzirdējis. Tomēr sasaiste starp Šveices antroposofu un Ẽ. Frommu drīzāk meklējama norādēs uz līdzīgām idejām un meklējumiem vai kopīgiem vēsturiskiem iespaidiem. Kaut, atceroties R. Šteinera mācību par āriešu rasi un vācu nācijas īpašo garīgo misiju pasaules atbrīvošanā no materiālisma un šìs mācības tālākajām vēsturiskajām konsekvencēm, šāda sasaiste arī ir visai problemātiska. Vieglāk atrodama sasaiste starp R. Šteinera mācību un tās adaptācijām garīgo biedrību aktivitātēs Latvijā.

Ja runājam par É . Frommu, tad viṇa uzskati šeit varēja būt zināmi vienīgi saistībā ar tiem viṇa darbiem, kas publicēti līdz 1936. gadam, tas ir, piemēram, "Über Methode und Aufgaben einer analytischen Sozialpsychologie" (Par analīiskās sociālpsiholog̣ijas metodi un uzdevumiem, 1932), „Die psychoanalytische Charakterologie und ibre Bedeutung für die Sozialpsychologie" (Psihoanalītiskā harakterolog̣ija un tās nozīme sociālpsihologijiā, I932), un arī tad, domājams, tikai profesionāḷ aprindās. Laikā, kad parādās pirmais plašāk pazīstamais E. Eromma darbs „Escape from Freedom" (Bēgšana no brīvības), tas ir, - 194I. gadā, neviena no minētajām biedrībām oficiāli vairs nepastāv.

Tādējādi, meklējot kādas kopīgas saiknes, jāatgriežas vien pie tās noskaṇas, kas valdīja 20. gadsimta sākumā Eiropā un atstāja savu ietekmi uz abiem domātājiem, kā arī uz atsevišķām kopīgām idejām, un te nosaukšu dažas no tām. Piemēram, kā Šteiners, tā Fromms daudz teoretizējuši par temperamentu un tā tipiem, un tieši tāpat kā Šteiners, arī Fromms nošķ̄īis temperamentu no rakstura. Taču, nebūdama speciāliste psihologijāă, atstāšu Šteinera un Fromma psiholog̣ijas koncepciju salīdzinājumu speciālistu ziṇā un pakavěšos pie viņiem abiem tuvas filosofiskas tēmas - jautājuma par cilvēka brīvību un tās iespējām.

I894. gadā R. Šteiners publicē savu darbu „Die Philosophie der Freiheit” (Brīvības filosofija). ${ }^{3}$ Kā raksta viens no viṇa darba tulkotājiem Maikls Lipsons (Michael Lipson), R. Šteiners pastāvīgi ieteicis šo darbu saviem studentiem kā sava veida praktisku rokasgrāmatu apziņas radikālajai izmainī̌sanai 
un „okultai saziņai”. ${ }^{4}$ Tiesa, vienlaikus uzsverot, ka viņš labi apzinās sava darba nepilnības un to, ka šī filosofija „saglabājusi rētas no visām ı9. gadsimta pārslimotajām bērnu slimībām". Tomēr būtiskākais ir viṇa pārliecība, ka patiesa brīvība ir tā, kas atbrīvo mūsu zināšanas, bet zināšanas savukārt ir atslēga uz mūsu personīgo atbildību. R. Šteiners ir pārliecināts, ka tieši viņa izveidotā antroposofija uzrunā cilvēku dziḷa cieņā pret gara brīvību: „Būt brīvam nozīmē domāt paša domas - ne tikai k̦ermeņa vai sabiedrības domas, bet domas, kuras rada dziḷākā, oriğinālākā, būtiskākā un garīgākā patība, individualitāte." ${ }^{\prime \prime}$

Jāpiekrīt R. Šteinera mācības pētniecei G̣ertrūdei Reifai Hjūzai (Reif Hughes), ka viṇa brīvības filosofija patiesībā ir meditācija par cilvēka spējām zināt un par individualitāti kā pamatu sociāli atbildīgai rīcībai. ${ }^{7}$ Viṇam brīìiba ir vienmēr radošs spēks, kas aizvien pilnīgāk ìstenojas mūsu personiskajās un starppersoniskajās dzīvēs. Un tieši tāpēc, ka mēs esam neierobežoti tajā, ko varam uzzināt par sevi un pasauli, mēs esam neierobežoti savā brīìibā, jo nav nekādu robežu, kuras mēs ar savām zināšanām nevarētu atcelt. ${ }^{8}$ „Domāšana ir viņpus subjekta un objekta. Tā veido abus šos konceptus tieši tāpat, kā tā dara iespējamus visus pārējos."

Šḳiet, ka tieši brīvības tēma ir tā, kas vieno R. Šteineru ar Ē. Frommu, jo Šteinera uzskatiem līdzīgas atziṇas mēs varam lasīt arī Fromma darbā „Escape from Freedom”. Vin,us abus tuvina jau tas, ka savu darbu Fromms ievada ar citātu no itālu renesanses domātāja Piko della Mirandolas darba „De hominis dignitate oratio”(Svinīgā runa par cilvēka cieṇu): „Nedz debesu, nedz zemes, ne mirstīgu, ne nemirstīgu mēs esam radījuši tevi, bet gan tādu, lai tu varētu būt brīvs pēc savas paša gribas un goda, lai tu pats būtu sevis radītājs un veidotājs. Tev vienam mēs dodam spēju augt un attīstīties pēc paša brīvas gribas. Tu pats sevī nes neierobežotās dzīves dīgli." ${ }^{10}$ Vai tad ne par šādām cilvēka brīvības iespējām iestājas R. Šteiners?

Vēl vairāk - arī E. Fromms savas brīvības filosofijas centrā novieto cilvēku un viņa gribu būt brīvam. Tā, piemēram, sava darba priekšvārdā viņš raksta, ka „brīvības jēgu pilnībā var saprast, vienīgi pamatojoties uz pilnu modernā cilvēka rakstura struktūras analīzi", ${ }^{11}$ un uzsver, ka indivīds ar viṇa vēlmēm un bailēm, emocijām un saprātu, tieksmēm uz labu un ḷaunu ir sociālā procesa pamatvienība, un, lai saprastu sociālā procesa dinamiku, mums ir jāizprot to psihologisko procesu dinamika, kas norisinās indivīdā, 
tieši tāpat kā, lai izprastu indivīdu, mums ir jāspēj viṇu saskatīt tās kultūras kontekstā, kas viņu veido. ${ }^{12}$

Tādējādi Ē. Fromms, tieši tāpat kā R. Šteiners, norāda uz cilvēka spēju atcelt jebkādas brīvības robežas. Tiesa, Fromma aprakstītajā cilvēka bēgšanā no brīvības mēs nepamanīsim to triumfālo un priekpilno pārliecību, ar kuru R. Šteiners apveltīijis savu brīvības robežām pāri ejošo cilvēku. Tieši otrādi, É E. Fromma cilvēks ir bezpalīdzīgs un viṇa dzìvi paralizējošu šaubu nomocìts, un, izmisīgi mēgeinot no visa tā aizbēgt, mēǵinot būt brīvs, viņš pat nepamana, cik daudz viņš pats spēj sevī un pasaulē mainīt. Viņa brīvība ved viṇu no zaudējuma uz zaudējumu, no vienas atkarības pie nākamās, no vienas ierobežojumu verdzības pie citas. ${ }^{13}$ Taču arī tāda var būt robežu atcelšana. Arī Fromma aprakstītā negatīvā brīvība (brīvība no) ir sākums cilvēka spējai transcendēt sevi pāri jebkādiem bioloǵiskiem, sociāliem domāšanas ierobežojumiem. Jau negatīvajā brīvībā veidojas atbilde uz Fromma jautājumu, vai ir iespējama arī pozitīva brīvība, kurā cilvēks spētu saglabāt savu patību un neatkarību un tajā pašā laikā būt vienots ar citiem cilvēkiem un pasauli?

Iepriekš pieminējām, ka Šteineram brīvība ir cilvēka spējas un zināšanas pilnībā realizēt savu individualitāti. Arī Fromma pozitīvā brīvìba ir sasniedzama cilvēka patības realizācijā, kuru viņš, starp citu, skata plašāk nekā Šteiners. Fromms uzsver, ka savas patības realizācija nav paveicama vien̄igi ar domāšanas aktu. Tajā piedalās visas cilvēka personības šķautnes, aktīvi izpaužot visu cilvēka emocionālo un intelektuālo potencialitāti jeb, kā savu domu turpina pats Fromms, „pozitīvo brīvību veido totālas, integrētas personības spontānā aktivitāte”. ${ }^{14}$ Paredzot to, ka viṇa darba lasītājam varētu rasties nesapratne par vārdu „spontānā aktivitāte” lietojumu, Fromms tūlīt pat paskaidro, ka te, ar atsauci uz vārda spontāns latīnu valodas sakni - sponte, domāta cilvēka brīvā griba, tas ir, tā pati jūdaiski kristietīgajā tradīcijā tik daudz apcerētā cilvēka īpašỉba, kas viņu atšksir no visa cita Dieva radītā un tuvina pašam Dievam. Kaut arī Fromma piedāvātajā cilvēka spontanitātes skaidrojumā nav atsauču uz reliğisku brīvās gribas skaidrojumu, tas, protams, neliedz lasītājam šādu sasaisti veidot un skatīt Fromma postulēto cilvēka pozitīvo brīvību arī plašā reliǵgiskās tradīcijas kontekstā. Šoreiz atturoties no šādas interpretācijas iespējas, atsauksimies vien uz vēl kādu Fromma uzsvērumu, proti, pēc viṇa domām, „spontānā rīcība ir vienīgais veids, kā cilvēks, neupurējot savas patības integritāti, var pārvarēt vientulības teroru, jo savas 
patības spontānajā realizācijā cilvēks atjauno savu vienotību ar pasauli - ar cilvēku, dabu un sevi pašu”. ${ }^{15}$

Brīvības un cilvēka patības realizācijas tēma ir tieši tā tēma, kas Šteinera un Fromma dialogā lauj iesaistīt arī raksta sākumā nosauktās Latvijas biedrības, kurām indivīda un nācijas brīvības jautājums ir viens no to darbības vadmotīviem.

Jāuzsver, ka, kā jau minēts iepriekš, Latvijas gara zinātṇu vēsture, no vienas puses, veidojas Šteinera antroposofijas (protams, ne tikai) iespaidā, vienlaicīgi rādot, cik atšķirīgi var interpretēt un tālāk attīstīt vienu un to pašu ideju, bet, no otras puses, tā precīzi atspoguḷo tos 20. gadsimta 20.-30. gadu intelektuālos impulsus un intensīvu garīgo meklējumu situāciju Eiropā, kurā veidojas arī Fromma uzskati. Te varam izvirzīt minējumu, ka Latvijā šajā laikā pastāvošais skatījums uz garīgo zinātni un tās attīstības ceḷu ir sava veida mezglojums, kas savieno Šteinera un Fromma pozīcijas.

Turpinājumā sniegšu nelielu ekskursu Latvijas gara zinātnes vēsturē. Latvijas Parapsihologijas biedrība sāk veidoties I924. gadā, taču oficiāli kā bezpel̦nas biedrība Rīgas apgabaltiesā reǵistrēta I925. gada I. aprīlīi. ${ }^{16} \mathrm{Tā}$ dibinātāja un pirmā valdes priekšsēēetāja ir Emma Apare. Saskaņā ar biedrības statūtu I. §, biedrības mērķis ir ,izpētīt un noskaidrot dažādas psiholoğiskas parādības; iepazīties un noskaidrot senās Austrumu metafiziskās mācības; attīstīt un iztirzāt dažādas psihologiskas parādības". ${ }^{17}$ Biedrības statūtu 2. $\$$ reglamentēja biedrības darbības praktisko pusi: savu mērḳu realizēšanai tā varēja rīkot dažādas slēgtas un publiskas lekcijas un priekšlasījumus, veidot bibliotēku un ierīkot lasītavas, izdot un izplatīt grāmatas un periodiskus izdevumus; kā arī rīkot dažādus seansus un eksperimentus. ${ }^{18}$ Par pēdējiem runājot, biedrībā tika organizēti, piemēram, spiritisma seansi, kurus vadīja Fricis Gailis, un biedrības biedru vidē tie bija l,oti populāri. Te lietderīga šḳiet neliela piezīme: atcerēsimies arī par Fromma pētījumiem, kuros parādās viņa interese par Austrumu metafiziskajām mācībām, piemēram, budismu. ${ }^{19}$

Ar Latvijas Parapsihologijas biedrības darbību ir saistīts arī „literāri-zinātniskais un filosofiski-reliğiskais” mēnešraksts „Zvani”, kas iznāk no 1926. līdz 1928. gadam. Tā izdevēja un redaktore ir jau pieminētā Emma Apare. Mēnešraksta I. numurā uzrunā lasītājiem uzsvērts, ka „Zvani” apskatīs visu to, kas „vērtīgs zinātnē, filosofijā un reliǵijā, kā arī noskaidros dažādas parapsihiskas parādības". ${ }^{20}$ Šos uzdevumus "Zvanu” autori arī uzticīgi īsteno. 
Pati Apare „Zvanos” publicējusi virkni rakstu ${ }^{21}$ par personības attīstības jautājumiem, piemēram, „Kā attīstīt un stiprināt atmin,u”, ${ }^{22}$ „Kā vecāki var iespaidot savus bērnus”, ${ }^{23}$ „Noslēgšanās un sevī iedzil,ināšanās”, ${ }^{24}$ „Kā stiprināt gribas spēku”25 un citus.

Mēnešraksta darbības apsīkums 1928. gadā sakrīt ar laiku, kad biedrībā radušos iekšējo nesaskaņu dēl E. Apare aiziet no biedrības vadības un arī no pašas biedrības, ${ }^{26}$ taču viṇas interese par parapsiholog̣ijas problēmām saglabājas un I929. gadā viṇa kopā ar literātu Danno - Danielu Kḷaviṇu ${ }^{27}$ sāk izdot „literāriski-filosofisku un okultisku mēnešrakstu (lekcijas koncentrētās domās)” „Kosmiskā Balss”. Mēnešraksta ı. numura ievadrakstā „Gaitu sākot” lasām, ka „,,Kosmiskā Balss”, resp. - gara balss - ies savā kosmiskās pasaules diženumā, aistetizējot un idealizējot smago zemes indivīda struktūru - filosofijas, Indo-Jogu, okultisma un daudz citu zinātnes un ideologu gaismā". ${ }^{28}$ Tomēr šo ieceri īstenot neizdodas, jo iznāk tikai viens mēnešraksta numurs, kurā publicēti Emmas Apares raksti „Spiritisma pamati”29 un „Sapñi un nojautas kā nākotnes pareǵotāji”. ${ }^{30}$ Īpašu savdabīgumu izdevumam pieškị Danno esejas „Nāves, dzīvības un galon,u sejas”, ${ }^{31}$ „Dāvana” ${ }^{32}$ un „Bērns vai sirmgalvis”, ${ }^{33}$ kā arī aforismu kopa „Domu, ideālu un garu sejas”, kuras vienojošo tēmu rāda šis aforisms: „Cilvēce lepojas ar moderno pasaules uzskatu, bet to iznes krop̣̣i, bez to galvenās struktūras, ideālisma un gara absolūtisma." ${ }^{34}$

To, ka „Kosmiskā Balss” izrādījusies viendienīte, ar kuru nav jālepojas, labi apzinājusies arī pati E. Apare, jo, kad ı93 I. gada novembrī viņa sāk izdot jaunu mēnešrakstu - "literāriski zinātnisku un filosofiski ētisku” izdevumu „Vain,ags”, tā ı. numurā norādīts, ka tas stājas „Zvanu” (nevis „Kosmiskās Balss”) vietā. Tomēr arī šis izdevums nav veiksmīgs, jo ı93 I. gadā vēl iznāk tikai divi „Vaiņaga” numuri.

„Vaiñaga” sakarībā nepieciešams plašāks paskaidrojums: tā iznākšana ir saistīta ar "Latvijas Gara Zinātņu biedrības” nodibināšanos I930. gadā. ${ }^{35} \mathrm{Ka}$ liecina biedrības dibināšanas sapulces protokols, starp biedrības dibinātājiem ir Emma Apare-Balodis un viñas dzivesbiedrs Aleksandrs Balodis, ${ }^{36}$ kas kḷūst par pirmo biedrības priekšsēdētāju. ${ }^{37}$ Biedrības I932. gada I 4. marta valdes sēdē A. Balodis atzīmēe „programmatiskos virzienus”, kuros biedrībai aktīvi jāstrādā: „I) jogisma, kabalisma, teosofijas un kristiānisma izstudēšana; 2) iegūtās zināšanas tūlìt pielietojamas dzīvē; 3) izplatīt zināšanas tautā. Turpat atgādināts, ka biedru vidē ,izkopjami tagad novārtā esošie 
trīs individualitātes dvēseles stāvokḷi: lūgšana - saistīta ar dziļu pazemību; disciplīna un izturēšanās - ievērojot vecākumu". ${ }^{38}$ Lai īstenotu izvirzītos uzdevumus, biedrība rīko saviem biedriem kā publiskus priekšlasījumus, tā slēgtus disputus. Trīs gadus vēlāk, kā lasāms biedrības i935. gada 20. augusta valdes sēdes protokolā, A. Balodis rosina savus domubiedrus atsākt arī mēnešraksta "Zvani” izdošanu, ${ }^{39}$ taču ši iecere paliek nerealizēta, jo, saskañā ar papildinājumu likumā par biedrību, savienību un politisko organizāciju slēgšanas, likvidācijas un reǵistrēšanas kārtību izṇēmuma stāvokḷa laikā un iekšlietu ministra A. Bērziņa I935. gada I2. oktobra lēmumu Nr. 666 biedrības valde savā sēdē 1936. gada 7. janvārī nolemj biedrības darbību pārtraukt. ${ }^{40}$ 1935. gadā Emma Balodis publicē nu jau vairāk nekā 400 lappuses biezu grāmatu - „Joga Jnigaes Noimantagara mācība Kosmosofija”. Drīz pēc grāmatas iznākšanas Ulmaņa valdība to aizliedz. Viens no aizlieguma iemesliem varētu būt grāmatā publicētās prognozes par jauna pasaules kara tuvošanos. Grāmata ar nosaukumu „Kosmozofija” atkārtoti tiek izdota Toronto (Kanādā) I981. gadā un Latvijā 20ı. gadā. Abi pēdējie grāmatas izdevumi atklāj kādu interesantu Emmas Balodis noslēpumu. Izrādās, ka aiz viņas vārda 1935. gada izdevumā slēpies grāmatas īstais autors - Aleksandrs Balodis.

Latvijas Valsts arhīva materiālos Aleksandra Baloža vārds atrodams arī saistībā ar „Kosmosofijas zinātṇu veicināšanas biedrības Latvijā” (1933-1936) darbību, kurā aktīvi darbojas arī vairāki citi Latvijas Gara Zinātṇu biedrības aktīvākie biedri, piemēram, gleznotājs Hugo Grotuss ar sievu Annu. Savukārt 1933. gada beigās LGZB darbā iesaistās arī tikko dibinātās „Kosmosofijas zinātṇu veicināšanas biedrības Latvijā” vācu un krievu sekcijas biedri, piemēram, Ellen Tumansky, Friede von Boddien, Nadežda Maikapar, Marta Johanson. ${ }^{41}$ „Kosmosofijas zinātn,u veicināšanas biedrība Latvijā” rìko slēgtus priekšlasījumus un šajos priekšlasījumos viens no aktīvākajiem lektoriem ir A. Balodis, kurš no 1934. gada 25. oktobra līdz 1936. gada i8. jūnijam ir nolasījis aptuveni so lekcijas krievu valodā. Ieskatam dažas viṇa lekciju tēmas: „Kosmosofija”, „Kosmosofiskā gnozeologija”, „Kosmosofiskā aksiologija”, „Kosmosofiskā teurǵija”, „Kosmosofijas egregora saturs, īpatnības un attiecības ar citiem egregoriem”, „Auras redzēšanas spēju attīstīšanas metodes un līdzeklị”, „Auras veidošanas un pārvietošanas tehnikas”, ”Mağiskās operācijas ar egregoriem”, „Simbolu aurisko lādiṇu iemiesošana”, „Simbolu aurisko spēku izlādēšana”, „Simbolu pagatavošana”, „Vadonības princips no okultā 
viedokḷa”, „Egregora vadoṇa un viņa locekḷu auriskās attiecības” u.c. I935. gada 25. jūlijā LGZB valdes sēdē tiek pārrunāta iespējamā apvienošanās ar Kosmosofijas zinātṇu veicināšanas biedrību Latvijāa, ${ }^{42}$ Rīgas prefektam tiek iesniegts lūgums aț̣aut organizēt kopīgu abu biedrību valžu sēdi, ${ }^{43}$ lai galīgi izlemtu jautājumu par iespējamo apvienošanos, taču galīgā lēmuma pieņemšana aizkavējas un vēlāk, kad Iekšlietu ministrijā tiek pien,emts lēmums par abu biedrību likvidāciju, šis nodoms zaudē savu nozīmi.

R. Šteinera antroposofijai tuvas idejas parādās jau Parapsihologijas biedrības darbībā un atspogul,ojas „Zvanu” idejiskajos uzstādījumos, kuru pamatuzdevums, kā jau citējām iepriekšs, ir relig̣ijas (kristīgā ezoterisma), filosofijas (te vispirms domātas Austrumu garīgās mācības) un zinātnes atziṇu apvienošana, lai izskaidrotu cilvēka attīstības un pilnīgošanās iespējas. Uz galveno tēmu, kas sasaista „Zvanos” publicētos rakstus, norāda jau šo rakstu nosaukumi: „Domu spēks un tā vara”,44 „Domu spēka iespaids uz organismu”,45 „Kas ir mentalisms”, ${ }^{46}$ un tā izteikta šādā formulējumā: „Domas valda pasauli. Tās ir stiprākas par miesu. Tāpēc ievērojams ir tikai tas, kas saprot šo dziļo patiesību.” ${ }^{47}$ Lìdzīgi R. Šteineram, „Zvanos” publicēto rakstu autori uzsver, ka „nezināšana ir visa posta cēlonis”, taču cilvēks aizvien var uzzināt ko vairāk. Te jānorāda uz l, loti būtisku, kaut netiešu R. Šteinera antroposofisko ideju turpinājumu - krievu Sudraba laikmeta filosofiju, kuru 20. gadsimta 20. gados Rīgā pārstāvēja filosofs Kalistrats Žakovs. ${ }^{48} \mathrm{Uz}$ viņa limitisma filosofiju, saskaṇā ar kuru „izziña ir mainīgs lielums, kas iet pretim savai robežai”,49 atsaucas arī „Zvani”, piemēram, 1927. un 1928. gadā tā pārstāstīta R. Krigera rakstā „Limitisma filosofija”. R. Šteinera antroposofijas ietekme parādās kaut vai šādā Krigera citētajā Žakova pamudinājumā: „Neapstāsimies, neuztrauksimies! Iesim uz priekšu nesteidzoties un arī neuzkavējoties. Nepiesiesimies pārāk cieši pie pastāvošām lietām. Gaisma vairāk un vairāk ieplūdīs mūsos." ${ }^{50} \mathrm{Te}$ vienīgi piezīmēsim, ka Krigers raksturo „limitismu kā cel̦u uz patiesību”, ${ }^{51}$ bet pašu Žakovu kā cilvēku, kurš „saprata cilvēces ciešanu un posta cēloṇus un sajuta sevī Pirmiespējamo". ${ }^{52} \mathrm{~K}$. Žakova limitisms norāda uz būtisku antroposofijas uzskatu: brīvība izzināt pasauli pastāvīgi atcel̦ iepriekšējo zināšanu robežas un tādējādi cilvēka izzinošais prāts nepieciešami tuvojas pareizai pasaules izpratnei jeb „nākotnes cilvēka atziņai”. ${ }^{33}$ Līdzīgas atziņas izskan arī „Vain,aga” 2. numura ievadrakstā: ,... „Vainags" zina, ko cilvēkam vajag, un saprot, kur un kā šīs vajadzības piepildīt. Vispirms viņš ieteic ikvienam iecelt 
savu apziņu skaidrā, gaišā un neizdzēšamā jēdzienā „Es esmu”. Pēc tam tūlīt lai „Es” apziņai saka: „Tev jāpētī dzīves būtỉba, jāmācās dzīvot, gūt uzvaras un pār dzìvi valdīt." ${ }^{54}$ Iepriekš minētie raksti par domas spēku tad arī aplūko to, kas ir dzīves būtība un kā pār to valdīt. Rakstā „Domu spēks un tā vara”, kura autorība apzīmēta ar burtu A., bet iespējams, ka aiz šì burta slēpjas Emma Apare, uzsvērts: „Domu spēks, kas darbojas cilvēka smadzenēs, ir vispilnīgākā spēka forma. ${ }^{55} \check{S}_{1}$ spēka noslēpumus mēs saucam par Dabu, Dzīvību, Prātu, Dvēseli un arī par Dievu. Lielais spēks, kas mīt mūsos, ir pilnīgs pretstats visam fiziskam un tas nepadodas nekādiem likumiem, kuri valda pār miesu. Šis spēks nav ieslogāms nekādā ierobežotā telpā, jo tam pieder visas telpas. Cilvēka domas dzīvo telpā arī pēc viṇa nāves." ${ }^{36}$ Raksta noslēgumā norādīts arī veids, kā, pateicoties savam domu spēkam, kuru gan cilvēks bieži neapzinās vai arī neprot to pareizi pārvaldīt, ir iespējams mainīt pasaules kārtību: „Kā fiziskās, tā garīgās dzīves apstākḷi ir ap mums esošo tuvāko un tālāko domu rezultāts, kuras ir atstājušas uz mums savu iespaidu. [..] Ja cilvēks grib atsvabināties no nelabvēlīgiem apstākḷiem, kuros viṇš dzivo un kuri atrodas ap vinuu, vajag likt pretī domu spēku tiem ārējiem domu iespaidiem, kuri valda pār viņu un atstāj iespaidu uz nākotni. Bez tam jāizmanto visi apslēptie iekšèjie spēki, lai radītu tos apstākḷus, kādos vēlētos dzīvot." ${ }^{57}$ Piezīmēsim, ka, mūsuprāt, šāda pozīcija ne tikai norāda uz R. Šteinera ideju ietekmi uz Latvijas „gara zinātnieku uzskatiem”, bet tajā iespējams saskatīt arī savdabīgu pāreju uz Fromma priekšstatiem par cilvēka cel̦u no negatīvās uz pozitīvo brīvību.

Vairākos biedrību izdoto žurnālu rakstos viegli varam atrast R. Šteinera izstrādātās antroposofās medicīnas ietekmes, ${ }^{58}$ piemēram, Dr. A. Ozoliṇa (Ainas Ozoliṇas) rakstā „Okultā medicīna"s9 vai jau pieminētajā rakstā „Domu spēka iespaids uz organismu”. Vērts pieminēt arī faktu, ka latviešu „gara zinātnieki” aktīivi sadarbojās ar „Vācu psihiskās pētǐšanas biedrību”.

Antroposofijai tuvā manierē biedrību izdevumos aprakstīts, piemēram, kā zinātniski izpētīt domas spēka darbības mehānismu un panākt šī spēka darbošanos sev vēlamā virzienā. Šai ziņā ievērības vērti ir vairākos „Vain,aga” izdevumos publicētie J. Rofanta raksti. ${ }^{60}$ Tà rakstā „Zinātne un okultisms” tā autors uzsver, ka „domu spēka faktora konstatēšana un atzī̌̌ana ir pirmais solis no materiālistiski-zinātniskās pasaules aploka pāri tās iežogojuma valnim”. Un tūlīt pat viņš secina, ka „domu spēka atzīšana par nemateriālistisku substanci jeb vielu ir pirmais taustāmais pamatakmens okultajā pasaulē". ${ }^{61}$ 
Savukārt rakstā „Okultisms un maǵija” viņš, līdzīgi Šteineram, uzsver, ka „ar domu spēku var radīt, veidot un pārvaldīt visu to, kas sastāv no elektroniskas vai fiziskas vielas un līdz ar to arī pār visu un visiem, kas atkarīgi no šîs vielas. Tie paši atklājumi mums rāda, ka no šīs vielas ir atkarīgs arī cilvēks. Tātad no paša cilvēka domu īpašībām izriet viņa neatkarība. Ja viņš prot domu spēkam pavēèt, ir neatkarīgs, brīvs". ${ }^{62}$ Aprakstot domu spēka darbības mehānismu, J. Rofants lieto tādus antroposofijā plaši diskutētus okultisma konceptus kā astrālais ķermenis, auras, domu klišejas un egregori. ${ }^{63}$ Tāpat viṇa tekstos uzstājīgā tonī ieskanas antroposofijai raksturīgais aicinājums neaizmirst par savas tautas īpašo egregoru un ar to saistīto tautas misiju: „Atliekas Latvijas tautas egregors. Bet kur viņš ir? Kur ir tā pavalstnieku organizētais vienības spēks...?" ${ }^{64} \mathrm{~J}$. Rofanta skatījumā tieši īpašā egregora iemiesošanās ir svarīgākais nosacījums tautas garīgajai atdzimšanai: „Pietiek, ja divas trīs patiesas sirdis paceḷ savas galvas Viṇa vārdā. Tā visuvarenā spēka enerğija plūdīs uz šo divu, triju darbību un sagraus visu, kas stāsies tai cel̦ā." ${ }^{65}$ Līdzīgas idejas izskan arī Latvijas Gara Zinātņu biedrības vadītāja un Kosmosofijas zinātṇu veicināšanas biedrības aktīvā lektora A. Baloža grāmatā „Kosmosofija”. Pēc savas stilistikas, aplūkotajām tēmām un pat piemēriem „Kosmosofija” ir tik tuva iepriekš aplūkotajiem J. Rofanta rakstiem, ka pat iespējams, ka J. Rofants un A. Balodis ir viena un tā pati persona. Netieši šādu iespēju apstiprina arī paša „Vain,aga” rakstu autora norāde par pseidonīma lietojumu. Atgriežoties pie „Kosmosofijas”, atzīmēsim, ka arī tajā nozīmīga vieta ierādīta egregoru aplūkojumam. Par egregoriem A. Balodis raksta šādi: „Neviens cilvēks nevar būt ārpus egregora. Tas jāsaprot - ārpus kādas citas cilvēku grupas kollektīvā iespaida. Ja cilvēks saka: „Es esmu viens pats ar sevi, es esmu ārpus visām cilvēciskām sabiedrībām, ārpus visiem egregoriem”, viṇš maldās." ${ }^{66}$ Turpinājumā A. Balodis uzsver, ka „katram egregoram labs viss tas, kas: I) veicina viņa gudrības klišeju rašanos, 2) rada un veicina egregorā sastāva, vienības, solidaritātes stiprumu, uztur sadarbības un kārtības disciplīnu, 3) sekmē reālo vērtību rašanos un uztur visas reālās dzīves saturu" ${ }^{67}$ Vienlaikus Balodis secina, ka „pašlaik vispasaules egregoriskais stāvoklis ir tragisks. Cilvēces vienība šķel̦as un par nabaga cietušo cilvēci veḷas pāri pašiznīcības vilnis. [..] Pēdējais laiks nākt pie apziņas, ka bez gara materiālā dzīve ir nedzīva, un atgriezties pie Dieva garā un patiesībā, uzṇemt jauno garīgo atziṇu klišejas un apvienoties jaunā egregorā”. ${ }^{68}$ Grāmatas noslēguma 
daḷā A. Balodis piedāvā arī garīgās tehnikas tautas un valsts auras attīrīšanai un jaunā egregora veidošanai: specifiskas lūgšanas un meditācijas, kurās apvienoti kristīgās un Austrumu reliǵiskās prakses elementi. Tāpat viņš uzsver garīgo biedrību nepieciešamību gara zinātnes jeb - viņa gadījumā - kosmosofijas turpmākajai attīstībai: „Kosmosofijas mācībā ir teikts, ka sadraudzība, sabiedrošanās, kopīgā domu izmaiņa ar idejas biedriem, radīs savstarpēju auras tīrīšanu un garīgo spēju attīstību automātiski. Sadraudzības kopībā būs vienota auriska izplūsma, egregorisko spēku saites starp apvienības locekliem. Viss tas sekmēs kosmosofijas klišejās paredzēto vērtību piepildīšanos dzīvē. Arī šinī zin̄ā tūlīit nepieciešama reāla, praktiska pārbaude." ${ }^{69}$

Ja ir pamatoti runāt par R. Šteinera un viṇa veidotās antroposofiskās kustības ideju ietekmi uz līdzīgām diskusijām Latvijā, tad tomēr neatbildēts paliek jautājums par to, kāda tad ir Ē. Fromma vieta visā šajā ideju mezglojumā. Śeit iespējams vienīgi atkārtot, ka gara zinātnes veidotājus Latvijā un $\bar{E}$. Frommu vieno kopīgs laikmets, Eiropas kultūras telpa un tajā notiekošais reliǵiski filosofiskais diskurss ar tā aktuālajiem izaicinājumiem, kas ir kopīgi gan R. Šteineram, gan Ē. Frommam, gan Latvijas „gara zinātniekiem”, taču uz tiem katrs no šì diskursa dalíbniekiem atbild citādāk. Latvijas gadījumā atbilde tiek meklēta antroposofiskās gara zinātnes attīstībā un atklājas, piemēram, A. Baloža kosmosofijas mācībā, ${ }^{70} \bar{E}$. Fromma gadījumā - viṇa humānpsihologiijā. Abos gadījumos mēs varam saskatīt kopīgu interesi par cilvēka identitātes meklējumiem, nepieciešamību atrast to sakņojumu, kas l̦auj viņam justies drošībā, personības pilnīgošanās iespējām un tās socializācijas nosacījumiem. Līdzīgi ir arī atsevišķ̧u problēmu risinājumi, piemēram, arī jau mūsu aplūkoto Latvijas biedrību preses izdevumos varam atrast rakstus par pareizas cilvēka „rakstura orientācijas"71 jautājumiem. Te nosaukšu Emmas Apares rakstus „Zvanos”: „Kā vecāki var iespaidot savus bērnus”,72 „Gribas spēka nozīme”, ${ }^{73}$ „Kā atrast savu uzdevumu” ${ }^{74}$ Taču šo jautājumu risinājumu salīdzinājums jau ir cita pētījuma uzdevums.

\section{Vēres}

I Steiner R. Anthroposophical Leading Thoughts. Anthroposophy as a Path of Knowledge. The Michael Mystery. / Translated by Mary Adams, and George Adams. London: Rudolf Steiner Press, 1998, p. 13. 
2 Atgādināšu, ka Ē. Fromms studē jurisprudenci 1918. gadā Frankfurtē pie Mainas un sociologiju Heidelbergā no I919. gada līdz 1922. gadam.

3 Vēlāk pārpublicēts anglu valodā ar nosaukumiem The Philosophy of Freedom (1916), The Philosophy of Spiritual Activity (1921) un Intuitive Thinking as a Spiritual Path (1995).

4 Lipson M. Translator's Introduction. Steiner R. Intuitive Thinking as a Spiritual Path. I Transl. by M. Lipson. Hudson (N. Y.): Anthroposohic Press, 1995, p. vii-viii.

5 Steiner R. Lecture of December 19, I919 (GA 333). Citēts pēc: Lipson M. Translator's Introduction, p. viii.

6 McDermott R. A. Rudolf Steiner and Anthroposophy. Modern Esoteric Spirituality. Ed. by Faivre A., Needleman J. New York: Crossroad Publishing Company, 1995, p. 288.

7 Reif Hughes G. Introduction. Steiner R. Intuitive Thinking as a Spiritual Path, p. xiii.

8 Par to vairāk sk.: Reif Hughes G. Introduction. Steiner R. Intuitive Thinking as a Spiritual Path, p. xiv-xvi

9 Steiner R. Intuitive Thinking as a Spiritual Path. /Transl. by Lipson M. Hudson (N.Y.): Anthroposophic Press, 1995, p. 52.

Io Turpat, p. vii.

II Fromm E. The Fear of Freedom. London (U.K.): Routledge \& Kegan Paul, 1942, p. viii.

I2 Turpat, p. ix.

13 Fromm E. The Fear of Freedom, p. 221.

14 Turpat, p. 222.

I5 Turpat, p. 224.

I6 Rīgas apgabaltiesas reǵistrācijas nodaļas atzīme par to, ka lūgums par statūtu reǵistrēěanu saņemts apgabaltiesā un ar I925. gada I. aprīla lēmumu Nr. 38I uz šo statūtu pamata ir reg̣istrēta Latvijas Parapsiholog̣ijas biedrība kā bezpel̦nas biedrība. Sk.: Parapsiholoğijas biedrības statūti. LVVA, Fonds 2135, apraksts I, lieta Nr. I, I2I. lapa.

17 Parapsiholoğijas biedrības statūti. LVVA, Fonds 2135, apr. I, lieta Nr. I, I20. lapa.

I8 Turpat.

I9 Sk., piemēram: Fromm E. Psychoanalysis and Religion. New Haven: Yale University Press, 1950; Fromm E. Suzuki D. T., Martino E. de. Zen Buddhism and Psychoanalysis. Harper, 1960.

20 Uzruna lasītājiem. Zvani [Rīga: E. Apare], Nr. ı, I926, ı. lpp.

2I Raksti publicēti ar iniciāli A., taču autorību viegli noteikt pēc rakstu tematikas un atkārtotām rakstu publikācijām.

22 Zvani, Nr. 2, 1926, 5.-7. lpp.

23 Turpat, I5.-16. lpp.; Nr. 3, I. lpp.

24 Zvani, Nr. 3, 7.--10. lpp.

25 Zvani, Nr. 6, 4.-7. lpp.

26 Šis fakts fiksēts biedrības 1929. gada 15. maija protokolā Nr. 2. LVVA, Fonds 2135, lieta Nr. 2, 2. lapa.

27 Ar pseidonīmu Danno Daniels Kḷaviņš izdevis vairākas grāmatas par garīgiem jautājumiem: Augstākā likumība. Rìga: autora izd., 1925; Abzolūtā laime: r. lekcija. Rìga: autora 
izd., 1926; Käda nerra kalna sprediki un tā mistrojumi: kā aforismi, anekdotes, lìdzības u.c. Jelgava: Kosmoss, 1928. Tuvāku biogrāfisku zinnu autores rīcībā pagaidām nav.

28 Gaitu sākot. Kosmiskā Balss [Rīga: Danno - D. Kḷaviņ̄̌], Nr. I, 1929, I. lpp.

29 Apare E. Spiritisma pamati. Kosmiskā Balss, Nr. I, 3.-5. lpp.

30 Apare E. Sapnni un nojautas kā nākotnes pareg̣otāji. Kosmiskā Balss, Nr. I, 5.-I2. lpp.

31 Kosmiskā Balss, Nr. I, I3.-I4. lpp.

32 Turpat, 15.-16.lpp.

33 Turpat, 16. lpp.

34 Danno. Domu, ideālu un garu sejas. Kosmiskā Balss, Nr. I, 3. lpp.

35 Latvijas Gara Zinātṇu Biedrība ar Rịgas apgabaltiesas reg̣istrācijas nodalıas lēmumu lietā Nr. 516 uz statūtu pamata registrēta 1930. gada 24. septembrī (reǵ. Nr. 2797).

36 Aleksandrs Balodis (dz. I892. g.) ir biedrības priekšsēēētājs līdz 1933. gada oktobrim, kad viņ̧̌ kopā ar Emmu Balodis pēc pašu vēlēšanās no biedrības izstājas. Tiesa, 1934. gada vasarā vini no jauna iestājas biedrībā un turpina tajā darboties līdz pat tās slēgšanai 1936. gada janvārī.

37 Latvijas Gara Zinātñu biedrības pilnas biedru sapulces protokols Nr. I, 1930. gada 15. novembrī. $L V V A$, Fonds I826, apr. I, lieta Nr. 571, 2. lapa. Sk. arī: LGZB valdes sēdes protokols Nr. I. $L V V A$, Fonds I826, apr. I, lieta Nr. 570, I. lapa. Saskañā ar ierakstiem, E. Apare ir ievēèèta par biedrības priekšsēèētāja biedri.

38 Latvijas Gara Zinātnuu biedrības valdes sēdes protokols Nr. 5 1932. gada 14. martā. $L V V A$, fonds I826, apr. I, lieta Nr. 570, 2. lapa.

39 Latvijas Gara Zinātṇu biedrības valdes sēdes protokols Nr. I2 1935. gada 20. augustā. $L V V A$, fonds I826, apr. I, lieta Nr. 571, 9. lapa.

40 Latvijas Gara Zinātnuu biedrības valdes sēdes protokols Nr. 42 1936. gada 7. janvārī. $L V V A$, fonds 1826, apr. I, lieta Nr. 570, I8. lapa.

4 I Sk.: LGZB pilnās biedru sapulces protokols Nr. II, 1933. gada 3. novembrī. $L V V A$, fonds I826, apr. I, lieta Nr. 571, 8. lapa.

42 Protokols Nr. 39. $L V V A$, fonds 1826, apr. 1, lieta Nr. 570, 14. lapa.

43 Noraksts no iesnieguma Rīgas prefektam. $L V V A$, fonds I826, apr.I, lieta Nr. 577, 5. lapa.

44 Zvani. Rīga: E. Apare, Nr. 7, 1927, 10.-12. lpp.

45 Zvani.. Nr. II/I2, 1928, 6.-I5. lpp.

46 Zvani. Nr. 9/10, 1927, 6.-10. lpp.

47 Gribas spēka nozīme. Zvani. Nr. 5, 1926, 8. lpp.

48 Kalistrats Žakovs (Жаков Калистрат Фаламеевич, 1866-1929), filosofs, etnogrāfs, profesors Psihoneirologiiskajā institūtā. Interesējies par teosofiju un antroposofiju, darbojies Sanktpēterburgas Religisiski filosofiskajā biedrībā, kurā daudz diskutēts arī par Šteinera idejām. No 192I. gada dzīvojis Rīgā. Par antroposofijas ideju ietekmi uz Sudraba laikmeta krievu filosofiju, skat., piemēram: Взыскующие града. Хроника частной жизни русских религиозньхх философов в письмах и дневниках. Москва: Школа „Языки русской китературы”, 1997; Тургенева А. А. Воспоминания о Рудольфе Штейнере и строительстве первого Геттеанума. Москва: Новалис, 2002.

Жаков К. Аимитизм. Bank, 1917, с. 3. 
50 Krigers R. Limitisma filosofija. Zvani. Riga: E. Apare, Nr. 9/10, 1927, 25. lpp.

5 I Turpat, 24. lpp.

52 Turpat, 25. lpp.

53 Krigers R. Limitisma filosofija. Zvani, Nr. II/I2, 1928, 28. lpp.

54 Vaiñags. Vaingags. Rīga: E. Balodis, Nr. 2, 1931, 2. lpp.

55 Salidzinājumam: "Unprejudiced observation shows that nothing can be attributed to the essence of thinking that is not found within thinking itself. One cannot arrive at anything that causes thinking if one leaves the realm of thinking behind". Steiner R. Intuitive Thinking as a Spiritual Path, p. 48.

56 Domu spēks un tā vara. Zvani, Nr. 7, 1927, 10. lpp.

57 Turpat, I2. lpp.

58 Mūsdienu konvencionālās medicīnas sasniegumi antroposofajā medicīnā tiek apvienoti ar zināšanām par izmain̄ām arī cilvēka dvēseliskajā jeb astrālajā un garīgajā jeb psihes līmenī. Antroposofā medicīna būtiski iespaidojusi mūsdienās populārās holistiskās medicīnas pamatnostādnes.

59 Ozoliņš A. Okultā medicīna. Vaiņags, Nr. 2. Rīga: E. Balodis, 1931, 50.-54. lpp.

60 Rofants J. Zinātne un okultisms. Vaiņags, Nr. I, 1930, 40.-64. lpp.; Rofants J. Okultisms un maǵija. Vaiņags, Nr. 2, 3.-20. lpp.; Nr. 3, I.-39. lpp.; Rofants J. Magija un Bībele. Turpat, 40.-96. lpp.

6 I Rofants J. Zinātne un okultisms. Vaiņags, Nr. I, I930, 50. lpp.

62 Rofants J. Okultisms un magija. Vainags, Nr. 3, 21. lpp.

63 Egregore jeb doppelgänger - domu formas, specifiska atmosfēra, kas veidojas konkrētā grupā. Par egregoru daudz rakstījis R. Šteinera skolnieks Valentīns Tombergs. Dzimis 1900. gadā Sanktpēterburgā, viņš 1920. gadā pārceḷas uz dzīvi Tallinā, bet 1925. gadā pievienojas R. Šteinera vadītajai Antroposofijas biedrībai.

64 Rofants J. Maǵija un Bïbele. Vain,ags, Nr. 3, 78. lpp.

65 Turpat, 79. lpp.

66 Balodis E. (Balodis A.) Kosmosofija. Joga Jnigaes Noimantagara mācība. Atreferējumi iz lekciju cikla: Dievs, pasaule un cilvēka stāvoklis tanī, 89. lpp.

67 Balodis E. (Balodis A.) Kosmosofija. Joga Jnigaes Noimantagara mācība, ıoı. lpp.

68 Balodis E. (Balodis A.) Kosmosofija, in . lpp.

69 Turpat, 462. lpp.

70 A. Balodis Otrā pasaules kara beigas sagaida Vācijā, vēlāk pārceḷas dzīvot uz Franciju. Viṇa mācību turpina Jēkabs Daizis. Viņš publicējis grāmatas „Kosmosa balss”, „Kosmoss ir atvērts Zemes dzīvei" u.c.

7I Te varam atsaukties, piemēram, uz Fromma darbu „Man for himself, an inquiry into the psychology of ethics".

72 Zvani. Rīga: E. Apare, Nr. 2, 1926, 15.-16. lpp; Nr. 3, I. lpp.

73 Zvani, Nr. 5, 1926, 6.-8. lpp.

74 Zvani, Nr. 8, 1927, I4.-16.lpp. 


\section{Igors Šuvajevs}

\section{Ērihs Fromms: brīvība un dzīvesmāksla}

Piedāvātās pārdomas ir mēǵinājums palūkoties uz Êriha Fromma darbos paustajām atziņām un to pamatotību Latvijas kontekstā. Īpaši tiek izceltas viñas atziņas saistībā ar brīivibu un dzīvesmākslu. Tas gan neparedz pārn̨emt Fromma skatijumu, tas paredz tikai palūkoties, kā viņa atziņas iespējams izmantot Latvijas gadījumā. Fromma saistība ar Latviju ir akcidentāla: publiskajā telpā vina vārds pirmo reizi acīmredzot figurē 193I. gadā, ${ }^{1}$ taču drīz vien tas nogrimst aizmirstībā. Publiskajā telpā tas Latvijā atgriežas pagājušā gadsimta astoņdesmitajos gados (neskaitot dažus epizodiskus pieminējumus presē iepriekš), tomēr nebūtu pamatoti runāt par viņa atziņu izmantošanu. Tādējādi piedāvātās pārdomas ir arī norāde uz nepadarīto, nepaveikto un vienlaikus uz to, kas šajā sakarī̄ā varētu būt produktīivs, varbūt pat nepieciešams.

E. Fromma pirmā monogrāfija ir viṇa studija „Bēgšana no brīìibas” (194I), kas nākamajos izdevumos tiek publicēta ar nosaukumu „Bailes no brīīibas”. Šo darbu viņš raksturo kā psiholog̣isku studiju: „Lai saprastu sabiedrisko procesu dinamiku, mums jāaptver psihologisko procesu dinamika, kas norisinās indivīdā."2 Psiholog̣ijas (jo îpaši dzịlu psihologijas) nozīmi vajadzētu nevis noliegt, bet, gluži pretēji, uzsvērt. Tomēr piedāvātajām pārdomām ir cita virzība, ko piẹ̦auj arī Fromma pozīcija. Viņš raksta par psiholog̣iskiem mehānismiem, vienlaikus norādot uz to sociālo nozīmīgumu. ${ }^{3}$ Tas l̦auj mainīt optiku, kas nepavisam neaizstāj Fromma skatijumu. Savukārt šî optika ir saistîta ar Mišela Fuko izstrādnēm un viņa rosinātajiem pētijumiem (ipaši ar governmentality studies). 
Runa ir par diskursīvām praksēm (lai vispārējās aprisēs tās raksturotu, izmantošu vienskaitlinieku). Diskursīvā prakse nav tikai pārdomu, tekstu producēšana, to izkārtošana, translēšana, proti, diskursa funkcionēšana. Tā ir arī darbības vai to elementi, noteiktu procedūru, tehniku izmantošana. Tās tikai škiet kā divas daḷas, tās ir veselums, ko var sadalìt. Lìdz ar to runa ir par apziņas un darbības vai dvēseles un prakses savijumu. Diskursīvā prakse ir sukcesīva, variabla un reg̣ionāla, taču tajā iezīmējas ideāltipiskas iezīmes. Tas nozīmē, ka var pastāvēt diskursi, to fragmenti vai elementi, ko neapzinās kā atbilstīgo praksi, un otrādi - var pastāvēt darbības, ko nesaista ar attiecīgo diskursu vai tā fragmentiem. Tas paredz pien,emt neapzinātā jeb bezapziñas pastāvēšanu un diskursīvās prakses izvēršanos ilgstošajā laikā. ${ }^{4}$ Diskursīvā prakse ir varas un zināšanu formu savijums un mijiedarbība. Tas nozīmē, ka diskursīvā prakse ir noteikta realitāte, kas piel̦auj noteiktu apzināšanos un pārvaldi, noteiktas varas, apziņas, zināšanu tehnolog̣ijas, struktūras un mehānismus. Izsakoties citiem vārdiem, nepastāv kaut kāda realitāte, kurai tiktu piemērotas kaut kādas idejas vai diskursi, nepastāv idejas, kurām piemeklētu noteiktu realitāti vai īstenošanas, prakses veidu. Taču pieņēmums par diskursìvo praksi paredz, kas pastāv arī attiecīgas racionalizācijas, neapzinātības formas, noteikti izstumšanas procesi u. tml.

Diskursīvajā praksē var izšķirt sociālos, politiskos, ekonomiskos, psiholog̣iskos u. tml. aspektus. Tomēr šajās pārdomās runa ir par ideāltipiskiem veidojumiem, to elementiem, iezīmēm. Tāpēc nepieciešams uzsvērt, ka, piemēram, patlaban var rasties domas vai darbības, kas atbilst diskursīvai praksei pirms simts vai vairākiem gadiem, kaut gan to veicējs var būt pārliecināts par pilnīgi pretējo. Tāa patlaban var veikt darbības, kas ir fašistiskas vai komunistiskas, to nemaz neapzinoties, vai paust domas, kas ir izteikti rasistiskas, taču tagadējā situācija tāda neškiiet. Vienlaikus tas nozīmē, ka pirms simts vai vairāk gadiem varēja veikt darbības, kas tolaik nešķita fašistiskas vai komunistiskas, vai paust domas, kas neškłita rasistiskas. Turklāt diskursīvā prakse ir daudzslān,aina, savulaik fonā esošais laika gaitā var izvirzīties priekšplānā un otrādi.

Ē. Fromms raksta par psiholoǵiskiem mehānismiem, savukārt piedāvātajās pārdomās runa ir par diskursīvās prakses jeb eksistences mehānismiem un struktūru, tehniku elementiem, nešķirot psihisko, dvēselisko no būšanas, pastāvēšanas. Fromms aplūko dažādus bēgšanas mehānismus, izceḷot trīs: bēgšanu autoritārismā, graušanu un automatizējošo konformismu. Bēgšanas 
pamatu viņš saskata indivīda izolācijā, atrautībā, bēgšanu viņš saista ar bezspēcību, niecīgumu, nedrošību, nepatstāvību. Iespējams, ka pati brīvība raisa bailes: „Brīdis, kad cilvēks redz sevi kā brīvu būtni, ir šausmu acumirklis, kad atveras bezdibenis kā melns caurums līdz tukšumam saspiestā matērijā." ${ }^{5}$ Lai kā tas arī būtu, Fromms uzskata, ka „cilvēka eksistence un brīvība nav škirama [jau] no paša sākuma”, ${ }^{6}$ un raksta par negatīvo un pozitīvo brīvību.

Brīvība, tās ideja acīmredzot ir Vakarzemes, Eiropas, Rietumu caurviju fenomens. Fernāns Brodēls to raksturo šādi: „No brīvību jēdziena līdz brīvības jēdzienam - lūk, formula, kas skaidro Eiropas vēsturi vienā no fundamentālākajiem tās attīstības virzieniem."’ Patlaban nav nepieciešams ielūkoties šajā vēsturē, gluži tāpat kā Fromma piedāvātajos ekskursos. Svarīgāk ir apjēgt, ka bieži vien netiek fiksēta brīvības aizstāšana ar brīvībām. ${ }^{8}$ Brīvība tiek aizstāta ar politiskām, ekonomiskām, sociālām un daudzām citām brīvībām. Tām ir svarīga loma cilvēka dzīvē, taču cilvēks var tās īstenot, pats nebūdams brīvs. Šādā gadījumā dzīve kḷūst par konstruējamu un plānojamu pasākumu kopumu, ko pamato un atdzīvina ar atraktīviem ideologiskiem vai idejiskiem veidojumiem. Šādi iespējama dzīve, ko lielā mērā raksturo automātisms. Taču šāda varbūtība piel̦auj arī iespēju, ka indivīds var izjust un pārdzīvot dzīves neīstumu. Šì iespēja var īstenoties visdažādākajās situācijās, kurās indivīds pēkšņi apjauš, ka nav pats, ka nedzīvo patīgu dzīvi.

Brīvība nav brīvību kopums vai kaut kāds optimāls to salikums. Tomēr noteiktus laikmetus, sabiedrības, kultūras raksturo zināms brīvību tips, kā arī to ideāls. Brīvības ir definējamas, jēdzieniski izvēršamas reālijas. Savukārt brīvība ir konstruktīva attiecībā pret cilvēka iespēju dzīvot, just, pārdzīvot kā cilvēkam. Brīìiba ir aktualizējama forma, kas atveidojas visā dzīves masīvā. Tā ir dzīves režīms, ko nav iespējams ignorēt (ignorēšanas gadījumā laikam nav pamata runāt par cilvēcisku dzīvi). Savukārt brīvības ir kultūrvēsturisks produkts, ko var ignorēt vai pat nesaistīt ar brīvībām. Tas gan nenozīmēe ka brīvība būtu pretstatāma brīvībām. Brīvība ir eksistenciāls akts, kurā vienmēr ir kaut kas „pāri dzīvei”, „pāri pārdzīvojumiem” esošs. Brīvība nav ietverama jēdzienā, kuru atliktu tikai iegaumēt un iemiesot dzīvē. Brīvība ir nevis fakts, kuram var piešķirt kādu funkcionālu nozīmi, bet gan cilvēka paša akts ar noteiktu jēgu.

Brīvība nav reducējama uz naturālo cēloṇsakarību vai atvasināma no tās. Brīvība nav arī kaut kāda spēja, kuru atliktu tikai īstenot. Cilvēkam nepiemīt 
spēja būt brīvam, cilvēks vai nu iespēj būt brīvs un prot tāds būt, vai arī tāds nav. Brīvība aptver visu cilvēku, visas viņa darbïbas jomas, t.i., brīvība ir „totāls fakts" ${ }^{9}$ Brìvība nav reducējama arī uz izvēles brīvību. Tas gan nenozīmē, ka nepastāv izvēles brīvība. Var izvēlēties kādu no brīvībām, dažkārt par to nākas cīnīties, kaut gan mūsdienās cilvēks lielākoties ir spiests izvēlēties. Nereti gan viņam nav attiecīgo zināšanu, viņš pat var nezināt, ka izvēlas un ko izvēlas. Šis izvēles stāvoklis var būt smags, nospiedošs, frustrējošs, tas var izraisīt komplikācijas. Tomēr izvēles brīvība nav pielīdzināma brīvībai. Brīvīva nav kaut kas tāds, ko atliktu vienreiz veikt uz visiem laikiem, tā ir akts, tā uzturēšana vai aktu virkne. Brīvība ietver paša piepūli, paša darbu. Brīvs iespēj būt tikai katrs pats, cita vietā nevar būt brīvs, t.i., cita vietā nevar veikt darbu, īstenot piepūli, kas veicama viņam pašam. Savā ziņā var teikt, ka brīvība ir katra paša zin̄ā un katrs pats par to ir atbildīgs.

Zināšanas par brīvību negarantē brīvību, to nevar iemācīt, līdz ar to brīvību nevar ieviest, uzdāvināt vai atņemt. Zināt, kā mīlēt, nenozīmē mīlēt vai prast mīlēt. Mīlētgriběšana var beigties ar gribēšanu. Gluži tāpat ir ar brīvību. Gan mīlestība, gan brīvība ir eksistences akti vai to virkne, šie akti vai nu pastāv, vai arī nepastāv. Tie ir eksistenciāli akti, kurus cilvēks aktualizē, aizvien no jauna tos pārdzīvojot un uzturot spēkā. Viens ir būt mīlestībā vai brīvībā, bet kaut kas cits - kaut ko zināt par to. Pastāv zināšanas, kurās dzīvo, un zināšanas, ar kurām dzīvo. Tas nozīmē, ka mīlestībai vai brīvībai piemīt zināšanas, ka tās pašas producē noteiktas zināšanas, taču pastāv arī zināšanas par mīlestību vai brīvību. Turklāt jāņem vērā, ka mīlestība ir vēsturiska un ka tā ne vienmēr ir savietojama ar brīvību.

Brīvība nav iespējama pa daḷām, tā ir visa uzreiz, vai arī tās nav. Brīvība nav progresiska, uz to nav attiecināmi tādi apzīmējumi kā „vairāk” vai „mazāk”. Brīvības nav nedz par maz, nedz par daudz; vai nu tā ir, vai arī tās nav. Varētu piel̦aut, ka brīvība ir kaut kas iekšējs, bet brīivibas attiecas uz ārējo. Savā ziṇā tas ir pareizi, jo brīvības nerada un nenosaka brīvību. Lai kādas brīvības pastāvētu, nav nekādas garantijas, ka ir arī brīvība, ka tā tiek aktualizēta un uzturēta. Tomēr brīvības saistǐšana ar iekšējo ir nepamatota, jo brīvība aptver visu cilvēku. Arī brīvības un brīvību pretstatīšana acīmredzot nav pamatota. Brīvības patiesi laikam pastāv tikai tad, ja tajās ievērpjas brīvība, izpaužas eksistenciālā brīvība. Var deklarēt dažādas brīvības, taču tās sabrūk, ja nepastāv brīvība, ja nav pietiekami daudz cilvēku, kas, būdami 
brīvi, uztur šīs brīvības. Arī brīvības ir jāprot uzturēt, t.i., jānostiprina to funkcionēšanai nepieciešamā „muskulatūra”. ${ }^{10}$ Bet nostiprināšana nav iespējama bez vingrināšanās. Vājas „muskulatūras” gadījumā brīvības parasti palīdz atcelt vai ierobežot paši dedzīgākie to aizstāvji. Brīvības var ieviest vai uzturēt nepilnīgā veidā, tomēr arī brīvības nepastāv bez atbildības, lai gan ieviestās brīvības var vienkārši sabrukt.

Brīvība un brīvības ir savītas ar „atbrīvošanos”. Šì atbrīvošanās var pastāvēt dažādās jomās un dažādos līmen,os, tā var figurēt kā „glābšana”, „izdzīvošana”, „atjaunošana”, ,attīrǐšanās” u. tml. Acīmredzot tā var figurēt arī „pozitīivi”, proti, figurēt kā programma, ar ko vienkārši nomaina iepriekšējo. „Atbrīvošanās fenomenā” var izšķirt trīs komponentus: sākuma un beigu stāvokḷa aprakstu un atbrīvošanās ceḷa izklāstu. Turklāt aprakstam nav jāatbilst patiesībai, pietiek, ka to pien,em kā nevēlamu vai vēlamu. Bet ceḷa izklāsts var pat nepastāvēt vai figurēt kā brīnumaina pārvērtība. Svarīgi fiksēt, ka atbrīvošanās var būt tikai zīmju sistēmas vai atskaites punkta nomaiṇa, paliekot tajā pašā eksistenciālajā stāvoklī. Atbrīvošanās gadījumā nepieciešams apliecināt noteiktu apstrādi vai pašapstrādi. Atbrīvošanās paredz to, ka pastāv aizbildṇi, aizgādņi, kuru pārziṇā ir veicamā procedūra. Atbrīvošanos raksturo nepietiekamība, kas noslēdzas ar progresismu, t.i., atbrīvošanās savā ziṇā ir nebeidzams process. To var aizskaidrot vai racionalizēt ar nemitīgu atsaukšanos uz „vecā” un ,jaunā” pretimstāvēšanu, savējā un svešā sajaukšanos u. tml. Atbrīvošanās, izraisīdama aizvien jaunas atbrīvošanās nepieciešamību, izvēršas par bēgšanu no brīvības un patiesības. Atbrīvojoties gan var gūt citas brīvības, taču principā atbrīvošanās ir tikai zīmju vai vērtību sistēmas nomain,a, paliekot tajā pašā eksistenciālajā stāvoklī vai kḷūstot par jaunās - atbrīvotības - sistēmas marioneti. Saistībā ar atbrīvošanos veidojas bezatbildības sindroms: lai ko indivīds darītu, atbildīgs ir nevis viņ̌s pats, bet gan citi vai noteikti apstākḷi.

Palūkojoties uz Latvijas vēsturi, var fiksēt Fromma aprakstītos bēgšanas mehānismus visā to daudzveidībā. Laika gaitā daži izvirzās priekšplānā, parādās transformācijas, jauni varianti un elementi. Lai cik netīkami tas būtu, nākas atzīt, ka Latvijas valsts - kā pirmā, tā tagadējā - ir sagadīšanās rezultāts. Principā var runāt par atbrīvošanās variācijām un nopietni pārdomāt to, vai Latvija nav simptomātiska atbrīvošanās zeme. „Pirmā Latvija” top revolūcijas (arī kara) fonā, bet revolūcijas mērksis, kā tas fiksēts jau pašāà 
vārdā, ir apvērst, sagraut. Turklāt šĩ graušana notiek uz faktiski esošu drupu fona. Arī tagadèjā Latvija tiek pasludināta par revolūcijas - dziesmotās revolūcijas - rezultātu. Apvērstā pasaule tiek vēlreiz apvērsta, t.i., graušana turpinās. Vārdā „revolūcija” ir ietverta arī atgriešanās nozīme, piel̦aujot atkārtošanos. ${ }^{11}$ Abos gadījumos pastāv sagadīšanās, t.i., īstenībā valsts nav pašu izcīnīta, kaut arī apgalvots tiek pretējais. Atsaucoties uz izcildinātu dzejnieku, var teikt: tā nu reiz gadījies, ka valsts ir radījusies. Simptomātiski ir centieni par atjaunotās valsts sākotni pasludināt 1990. gadu, kaut gan pasludināšanai labvēlīgi apstākḷi sagadās tikai I99ı. gadā. Šajā sakarībā var atsaukt atmiṇā Fromma norādīto bezspēcību, nepatstāvību, jo par pašu neveikto nekad nevar būt īsti drošs. Taisnības labad gan jābilst, ka Latvija šajā ziṇā nav unikāla, arī citviet ,izcīnīšana” bieži vien tiek veikta vēlāk, pamatojumi tiek rasti vēlāk. Taču šādos gadījumos parasti revolucionāru skaits laika gaitā tikai pieaug, viņi (un arī viņu pretinieki) kḷūst aizvien kaislīgāki un resentimentālāki.

Pirmās republikas veidošanās nav viegla. Taču bēgšanas mehānismu kontekstā svarīgāk ir norādīt uz visai nožēlojamo 1934. gada apvērsumu un bezgaumīgā autoritārā režìma iestrādi. ${ }^{12}$ Var iebilst pret epitetu lietošanu, taču veikuma bezatbildība ir skaidri redzama jau tolaik un to nevar attaisnot ar atsauci, ka vairumā Eiropas valstu tiek izveidoti autoritāri, totalitāri režīmi. Starp citu, apvērsums tiek nodēvēts par Trešo atmodu. To aizmirstot vai izstumjot, par Trešo atmodu vēlāk nodēvē aston, desmito, devin, desmito gadu notikumus. Apvērsums atsedz, ka ievingrināšanās brīvībā ir tikai šķ̧itums, kaut gan brīvību zin̄ā, pat neraugoties uz pasludināto karastāvokli, Latvijā nemaz nav tik necivilizēti. Apvērsums uzrāda, ka brīvība tiek uztverta kā važas (E. Virza), no brīvības bēg.

Šādi intensīvi tiek producēta diskursīvā prakse, kuru raksturo trīs elementi: vienotība, vadonība, tautiskums jeb latviskums. No brīvības bēg autoritārismā. Tas atveidojas arī dažādos masu pasākumos, ko īsteno, lai šādu bēgšanu nodrošinātu. Šāds pasākumu komplekss, piemēram, ir par svētkiem pasludinātu svinību organizēšana (Darba svētki, Pḷaujas svētki, Meža dienas u. tml.). Vadoņa braucieni pa Latviju nodrošina saikni ar masu. Salīdzinot šos pasākumus ar pasākumiem citviet Eiropā ( $\operatorname{arī~Padomju~Savienībā),~nevar~}$ fiksēt nekādas strukturālas atšksirības. Tiek īstenota sava veida pastorāla vara, nodrošinot masificējošās sabiedrības tapšanu par noteikta veida masu. Masificēšanās ir viens no bēgšanas mehānismiem, no brīvības bēg masā. Tas tiek 
papildināts ar mēnessērdzīgiem latvietības meklējumiem, kam jāatveidojas pat cilvēka augumā. Savukārt vadonis ir tēviš̌kīga figūra, ap kuru pulcējas tautiskā masa; pēc gadu desmitiem vērojami mātišksās figūras izveides centieni. Drīz vien šì diskursīvā prakse ieaug jaunā sistēmā: „Taču šī sistēma bēgšanas no brīvỉbas vietā bija likusi brīvības neesamību." ${ }^{13}$ Šāds secinājums ir pārsteidzīgs, iespējams, ka tajā neapzināti pat ievijušās noteiktas vēlmes.

Runa ir par turpmāko okupāciju, kuru arī iezīmē divas tēva figūras, proti, Staļins un Hitlers. Brīvība nekur nepazūd, arī šajos laikos pastāv cilvēki, kuri iespēj būt brīivi. Citādi ir ar brīvībām, tās tiek transformētas. Šajā procesā svarīga loma ir baiḷu radīšanai, to uzturēšanai un ienaidnieka producēšanai. ${ }^{14}$ Bēgšanas mehānismu kontekstā trīsdesmitajos gados principā tiek likti pamati jaunajām okupācijām, katrā ziņā indivīdi tām jau ir sagatavoti. Bēgšanai autoritārismā pievienojas graušana, producētā ienaidnieka iznīcināšana vai mēginājumi to pārveidot. Latvija kḷūst par vienu no asinszemēm, ${ }^{15}$ par to gādā abi tēvišķie vadoṇi, kas simbolizē atbrīvošanu. Jāatzīst, ka dažkārt viņiem tā arī izdevusies, proti, ir vai ir bijuši indivīdi, kurus izdevies atbrīvot no cilvēciskuma. Vadonība ir spēkā abos gadījumos. Ne mazāk svarīga ir vienotība, tiesa, atšķirīgās nozīmēs. Tas pats attiecas uz tautiskumu, kas padomiskās atbrīvošanas gadījumā pamazām iegūst padomju tautas veidolu, kura lielākoties sazinās krievu valodā. Iespējams, ka pastāv vēl viens veids, kā bēgt no brīivibas, proti, bēgšana valodā. Taču to var izprast arī kā vienu no brīvībām - jauna valoda sniedz jaunas iespējas, dažkārt nodrošinot arī jaunu identitāti. Padomju Latvija pastāv pietiekami ilgi, lai tās pastāvēšanas beigu posmā sāktu dominēt cits bēgšanas mehānisms, proti, automatizējošais konformisms.

Šāds skatījums, protams, ir vienkāršots, taču tā nolūks ir uzrādīt Fromma aprakstītos bēgšanas mehānismus Latvijā. Detalizētākā pētỉjumā un izklāstā aina būtu sarežǧîtāka, tāpēc norādī̌su uz vēl dažām norisēm, kas saistītas ar bēgšanu no brīvības.

Bēgšanu no brīvības iezīmē arī vēsture, tās izpratne, kas bieži vien sedimentējas kolektīvajā atmiṇā un ko nereti izmanto dažādām manipulācijām (ideolog̣iskām, politiskām u. tml.). Šajā ziṇā Latvijā ir vērojama vairākkārtēja vēstures noliegšana kā jaunas vēstures sadomāšana. Pirmais noliegums aizsākas līdz ar valsts nodibināšanu I918. gadā. Ietverot šo noliegumu simboliskā formulējumā, var teikt: latvieši dzīvojuši dzintara pilīs, taču tad nākuši 700 
verdzības gadi. Šādi tiek īstenota vēstures nacionalizēšana, kuras elementi, starp citu, tiek pārn,emti no vācbaltu vēstures skatījuma. Šajā diskursīvajā praksē svarīgs elements ir gadsimtiem ilgā verdzība. Svešie, citi ir paverdzinājuši, laupijjuši patstāvību, taču beidzot atkal atgūta brīvība. Šāda dispozīcija neḷauj fiksēt resentimentalitāti. Tā neḷauj fiksēt arī šāda skatījuma ǵenealog̣iju, kas iesniedzas ı8. gadsimtā. Autoritārajā Latvijā iezīmējas otrais vēstures noliegums, kura simboliskais kopsaucējs ir vēstures latviskošana. Latviskota tiek ne vien vēsture, latvietỉba ir ideologijas elements, kas tiecas iesūkties katrā dzīves porā. Trešais vēstures noliegums iezīmējas devin, desmitajos gados. Tas ietverams simboliskajā izteikumā „50 okupācijas gadi”, ko pavada arī latvietības reanimēšanas centieni.

Šiem noliegumiem ir dažas kopīgas iezīmes. Viss iepriekšējais ir tikai sava veida priekšvēsture, ko nepieciešams noārdīt, lai atjaunotu patieso. Gala iznākumā veidojas situācija, ka vēstures nav, ka tā nav iestrādāta. Uzskatāmi to apliecina 50 gadu okupācijas fenomens. Tas ir paradoksāls, jo, no vienas puses, ar to var izskaidrot visas nebūšanas, bet, no otras puses, - tā nav, jo vēsture turpinās, sākot ar 1940. gadu. Pa starpu labākajā gadỉjumā ir neīstā vēsture. Nīstā tēva vara ir saārdìta, nefiksējot ambivalenci, kas ḷauj tai modificēti atkārtoties. Šis vēstures posms nav iespējams bez kolaboracionisma, taču kolaborantu nav. Kādreizējais shematisms „700 gadi” tiek aizstāts ar jaunu shematismu „ङం gadi”, svešo statuss tiek piemērots citiem. Šādi nav arī spēka atzìt pašiesaistītîbu deportācijās, jo tās taču ir veikuši citi. Šajā vēstures posmā ir ievijies vēl viens dīvains fenomens. Tas ir karš, kas laikam vēl nav beidzies. Vieniem tas ir Otrais pasaules karšs, savukārt citiem tas ir Lielais Tēvijas karš. Šis karš sašķēla Latvijas tautu un turpina to šķ kelt. Kā viena, tā otra puse cīnījās, skatījās acīs nāvei, dažiem izdevās izsprukt no tās apskāvieniem. Taču ne vieni, ne otri necīnījās par Latviju, jo tas vienkārši nebija Latvijas karš. Psihologiski katrs gan var domāt pretējo, būt par to pārliecināts. Šis karš nav beidzies kaut vai tāpēc, ka uzvara tiek atzīmēta atšķirīgi. Ir izveidojušās un tiek uzturētas divas masas, kas karu redz atškirirīgi. Turklāt šīs masas tiek nacionalizētas, viena no tām tiek pasludināta par krievvalodīgu, kaut gan tādu krievvalodīgo nacionālā nozīmē nemaz nav. Dīvains šis karš ir arī tāpēc, ka tas aizvien tiek uzturēts, kaut gan nāves elpu jutušo ir tik maz.

Ne mazāk savdabīgs fenomens ir deportācijas. Tās ir jo baisākas tāpēc, ka deportācijas tiek pārvērstas par vienskaitlinieku, kurā cieš tauta. Aiz šì 
vienskaitlinieka pazūd indivīdu pārdzīvojumi, nereti uz mūžu gūtās psihosomatiskās komplikācijas. Singularizēšana iezīmē ne tikai deportācijas, Latvijā visai bieži ir dzirdams „Mēs”. Var pat rasties iespaids, ka paša nav. Mēs ir tas, kas l̦auj paslēpties, atcelt sevi, tā ir sava veida sevis izlielīšana un savas atbildības nepieņemšana. Šim „Mēs” tiek pretstatīti „Viņi”, kas pie visa arī vainojami. Iespējams, ka indivīda Es nemaz nav izveidojies, ka viņš var rïkoties tikai kā „Mēs”. Reizēm, protams, var dzirdēt arī uzstājīgo Es, kas nereti gan ir infantilais, narcistiskais Es vai tāds Es, kuram nepieciešams, lai viņu mīlētu visa pasaule. ${ }^{16}$ Katrā ziṇā pašpietiekamības trūkums nav noliedzams, un tas tikai veicina bēgšanu no brīvības.

Pastāv vēl viens vēstures noliegums, ko iespējams uztvert kā fonu, kas līdzdalīgs pārējās noliegšanas formās. Runa ir par ı. gadsimtu, kad tiek sadomāta Austrumeiropa. ${ }^{17}$ Jau tolaik tiek iezīmēts „Dzelzs priekškars”, kas vēl reljefāk tiek izcelts 20. gadsimta pirmajā pusē, lai tiktu uzturēts spēkā pēc Otrā pasaules kara. Un šis priekškars joprojām nav novākts, tas ir tikai modificējies (piemēram, vecā un jaunā vai divu ātrumu Eiropa u. tml.). Austrumeiropas sadomāšanā iezīmējas vairāki elementi, kas aizvien liek sevi manīt. Austrumi tiek domāti, iztēloti kā kaut kas kārdinošs, vilinošs, tāds, ko vajadzētu iegūt un apgūt. Austrumi apbur un raisa bažas, jo tos uztver kā kaut ko necivilizētu, primitīvu, pat barbarisku. Šos Austrumus raksturo nekārtība un neceḷi, tur sievietes un vīrieša loma nereti ir mainīta. Sievietes ir mežonīgi skaistas, stipras, gudras, bet vīrieši - visnotal lopiski radījumi. Tur tiek dziedāts, dzerts un sists. Vajadzības gadījumā gan priekšplānā var izvirzīt šo dabasbērnu īpašo tuvību dabai, dabisko apḳēīibu u. tml.

Austrumeiropas sadomāšanā parādās vēl daži noturīgi elementi. Tiek fiksēti tautu arhīvi, proti, folklora. Šādi rodas sava veida etnogrāfiskā pase, kas apzīmogo austrumeiropiešus. Viṇi ir folklorizējamas tautinas. I8. gadsimtā rodas ne tikai mūsdienu romantiskā, bet arī politiskā nacionālisma pamats. Savos aizsākumos tas ir visai dīvains, proti, jūties savā sirdī, piemēram, latvietis, bet neraugies, kas notiek ar tavu zemi. Austrumeiropas sadomāšanā runa ir par fantāzijām, bailēm, vēlmēm, iekārēm, kas tiek projicētas uz tiem, kam ar to nākas sadzīvot. Lai gan arī vietējie nereti labprāt iesaistās šādu diskursu producēšanā. Kolektīvajā atmiņā ir iestrādāts, gandrīz vai iegravēts tas, ka latvieši ir zemnieku tauta, viṇi ir dziedātājtauta. Tas ir pārn,emtais skatījums uz sevi, pašpietiekamība ir rodama labi ja folklorā, apburošā barbarismā. Taču 
arī to var nepamanīt. Arī Fromms ir pamanījis tikai padomju Krieviju, lai gan tad jau pastāv asiņainā Padomju Savienība, kuras pastāvēšana nav iespējama bez tiem pašiem rietumeiropiešiem. Aplūkojot bēgšanas mehānismus un rakstot par nacisma psihologiju, Fromms uzskata par nepieciešamu norādīt tikai uz vārda „sociālisms” aplamo lietošanu: „Es domāju par Krieviju, kur vārds „sociālisms” ir ieguvis maldinošu nozīmi." ${ }^{18}$ Fromms norāda, ka tur ar lielo iedzīvotāju masu manipulē spēcīga birokrātija...

Latvijas pastāvēšanā ir vēl viens zīmīgs fenomens, kas pastāv vismaz no 20. gadsimta sākuma. Runa ir par tautas izmiršanu. Laiku pa laikam šis diskurss uzvirmo, lai ar morālās panikas sacelšanu risinātu uzdevumus, kurus patlaban nav svarīgi aplūkot. Taču šādi izdodas šo to nepamanīt. Kara priekšvakarā Latvija „atbrīvojas” no vācbaltiešiem. ${ }^{19}$ Drīz vien „atbrīvojas” no ebrejiem. Atliek vien pieminēt deportācijas un emigrācijas. Savukārt pēdējos pārdesmit gados Latvija ir „atbrīvojusies” no vairāk nekā piektdaļas populācijas. Faktiski latvieši nav nedz izmiruši, nedz arī izmirst, taču „atbrīvošanās” apmēri ir vienkārši fantastiski.

Zemniekam nepiedien migrēt. Taču arī migrācijas apmēri Latvijā pēdējos pārsimt gados ir fantastiski. Tiesa, vērtējums ir atškirīịs. Dažkārt to vērtē kā nodevību, bēgšanu, lai gan tā var būt tikai jauno brīvību izmantošana. Principā migrācija ir tikai pārvietošanās, pārcelšanās - īslaicīgāka vai ilgstošāka. Arī izmiršana ir viens no migrācijas veidiem; nomiršana, ja vien šim stāstam tic, ir tikai pārcelšanās uz citu vietu. Šāda „migrācija” ir arī pašnāvības, un šajā ziṇā Latvija stabili turas līdera pozīcijās Eiropā. Šāda pārcelšanās jeb bēgšana var notikt arī fantāzijās, iedomās, dažādās mānijās. Var pārcelties alkoholismā, valstiski piel̦autā un nodrošinātā apdullināšanās formā. Var pārcelties internetā, padarīt dzīvi par tvītošanu. Bēgšanas formas ir dažādas, tāpēc svarīgi sniegt par to norēķinu, izkopt precīzu domāšanu un rīcību.

Pēdèjā laikā Latviju raksturo neviendabīgā vienlaicīgums, lai gan to var teikt par pēdējiem pārsimts gadiem. Patlaban to padara akūtu visdažādākie mediji. Uzskatāmi tas atklājas popkultūrā, dzīves estetizācijā, kuras neatņemama sastāvdaḷa ir šovi (no sporta līdz koncertiem un izstādēm), dzīves virtualizācija (no Second Life līdz tvītošanai un Facebook bezsejainībai) un ķermeņu konstruēšana un dēkaina to izbaudīšana (no seksa un drogām līdz ekstrēmajam sportam). Tas viss Latvijā pastāv un šādi var nepamanìt dzìves brazilizāciju. Tas nozīmē, ka vieni specializējas pel̦nā, bet otri - zaudējumos. 
Gandrīz vai Eiropas centrā veidojas Trešā pasaule, un tāda veidojas arī Latvijas sabiedrībā. Latviju it labi raksturo prekariāts - terminēto masas, kuru pašuzturēšana ir pašu zin̦ā. Trūkums, nabadzība var raisīt ciešanas, taču vēl nomācošāk var iedarboties paša darba devalvēšanās, sejas, stājas zudums, tā vietā stājas pazī̌sanās, izsišanās u. tml.

Šādi iezīmējas modernās biopolitikas un atzīšanās diskursīvās prakses. Saskaṇā ar M. Fuko atziṇu, Rietumu cilvēks ir radies kā atzīšanās dzīvnieks, taču, n,emot vērā visu Eiropu, proti, arī tās austrumus, šis cilvēks ir nožēlojošais zvērs, blēdīgās atzī̌̌anās praktizētājs. ${ }^{20}$ Atzīšanās ietver atzīšanu, turklāt Krievijā (plašāk - Padomju Savienībā un tās ietekmes sfērā) šajā diskursīvajā praksē parādās arī modifikācijas - pazī̌sanās, izsišanās utt. Tā ietver atmaskošanu, izlikšanos, tā nav iespējama bez cilvēka ar iniciatīvu, kas izvēršas visdažādākajās aktivitātēs. Turklāt tas sajūdzas ar homo imperii veidošanu un veidošanos. I8. gadsimtā aizsākas Krievijas impēriskā diskursīvā prakse, kas skar arī Latviju. Krievija ir impērija, kas kolonizē un ko zīmīgi raksturo paškolonizācija. Un „21. gadsimtā pasaule ar izbrīnu seko pēcpadomju Krievijas impēriskajām ambīcijām”, ${ }^{21}$ lai gan Latvijā drīzāk jau tas nav nekāds izbrīns. Latvija tiek ierauta turbulentās diskursīvās praksēs. İpaši izceḷams ir rasisms. Tas ir gan sociālais rasisms (nominācijas ir atšķirīgas: komunizācija, boḷsevizācija, sovjetizācija u. tml.), gan biologiskais rasisms (Latviju visvairāk skar tā nacionālsociālistiskais variants). Savukārt impēriskās diskursīvās prakses ietvaros var izcelt nacionālo (Krievijas) rasismu. ${ }^{22}$ Turklāt šî forma vienu laiku ir ievijusies arī sociālajā rasismā.

M. Fuko ir aplūkojis disciplinārās sabiedrības rašanos, kurā atzīšanās ir sajūgta ar uzraudzīšanu. Savukārt Eiropas austrumos šĩ uzraudzīšana principā paredz pašuzraudzī̌̌anu. Fuko ietekmē rodas gan governmentality studies, gan surveillence studies. ${ }^{23}$ Uzmanība tiek pievērsta ne tik daudz valstij, cik sabiedrībai un uzraudzī̌sanas dažādajām tehnologijām. Uzraudzī̌ana ietver pašuzraudzǐšanu, tā izvēršas ne tikai dažādās tehnologijiās, bet arī literatūrās, filmās u. tml. ${ }^{24}$ Tas atveidoja arī valodiski, noteiktās diskursīvās praksēs, piemēram, kontrolingos, monitoringos, supervizijās utt. Runa ir par (paš)uzraudzī̌anas, kontroles sabiedrību. Turklāt šis valodiskais piemērs l̦auj norādīt uz jaunu bēgšanas veidu Latvijā, proti, uz bēgšanu angḷ valodā. Ja savulaik rusifikācija ir bijusi uzspiesta, tad patlaban vērojama labprātīga angloamerikanizācija. Savukārt uzraudzīšanas diskursīvo praksi visuzskatāmāk laikam var 
raksturot, norādot uz videonovērošanu. Tās ieviešanai var izmantot dažādus racionalizējumus. Taču jau tagad ir skaidrs, ka attiecīgie pasākumi nenodrošina vardarbības samazināšanos. Ar attiecīgajām tehnologiijām principā var pasargāt nevis personas, bet gan lietas. Turklāt ir skaidrs, ka tehnika vairs nav neitrāla, savukārt iegūtā informācija izraisa škirirošanas, uzglabāšanas un izmantošanas problēmas. Toties indivīds lielā mērā konstituējas kā pašizrādīšanās un pašuzraudzī̌šanas dzīvnieks, kuru raksturo reducētas eksistences formas un kuram nav svešs mediālais narcisms.

Svarīgs modernās sabiedrības faktors ir augstākā izglīiība un zinātne. Mūsdienās gan bieži vien tas pārtop neizglìtotībā, nepamatotā zināšanu sabiedrības cerību un vēlmju lološanā. ${ }^{25}$ Latvijā šìs jomas neoliberālisma iespaidā tiek sistemātiski grautas, kaut gan neoliberālisma postošā, graujošāā iedarbība ir visnotal apzināta. ${ }^{26}$ Turklāt Latvijā šai diskursīvajai praksei ir visai sena ǵenealoǵiskā cilme. Izmantoto frāžu un darbību ǵenealoǵija atklājas L,encina sacerējumā „Valsts un revolūcija”. ${ }^{27}$ Var tikai atgādināt, ka sociālo rasismu praktizējošie komunisti ir mazākums, kas sevi izliela par vairākumu, proti, boḷ̌sevikiem, lieliniekiem. Iespējams, ka var runāt par neokomunismu, kas itin labi sadzīvo ar neoliberālismu. Katrā ziṇā Latvijā pēdējā eksprezidenta un viņa līdzskrējēju darbības izvēršas kā graušana, nodrošinot reducētas dzīves formas un shematisku, frāžainu ideologiiju un propagandu, kas var sacensties ar komunisma un nacionālsociālisma centieniem. Nereti šos grāvējus ir piemeklējusi amnēzija vai arī vin,i to izrāda izlikšanās ietvaros. Governmentality studies ietvaros ir izkristalizējusies atziņa, ka demokrātija un totalitārisms ne vienmēr ir pretstatāmi lielumi, ka demokrātijā iemīt totalitarizējoši elementi. ${ }^{28}$ Tādējādi Latvijā iezīmējas sabiedrības receklīgums, sabiedrība ir tendēta kḷūt par masificētu indivīdu sabiedrību, kuri tiek deindividualizēti. Bēgšana no brīvības var izvērsties visdažādākajās (paš)uzraudzī̌anas procedūrās. Un izglītotības graušana to tikai atvieglina, jo nodrošina receklīgas masas pastāvēšanu, kuru satur dažāda veida izrādīšanās, pašuzraudzī̌̌anās.

Uzraudzīšanas sabiedrību raksturo bail,u politika. Un Fromms uzskatāmi ir parādījis nedrošîbas, baiḷu, šausmu saistību ar bēgšanu no brīvības. Turklāt bēgšanas mehānismus viņš saista ar noteiktiem raksturiem, raksturu orientācijām. Darbā „Bēgšana no brīvības” tiek iezīmēts autoritārais raksturs, liekot pamatus mācībai par raksturiem. ${ }^{29}$ Darbā „Cilvēks pats sev” (1947) bēgšanai autoritārismā atbilst mazohistiskais jeb receptīvais un sadistiskais 
jeb ekspluatējošais raksturs. Automatizējošais konformisms ir sajūgts ar mārketinga jeb patērējošo raksturu. Savukārt grāmatās „Cilvēka sirds” (1964) un „Cilvēka destruktivitātes anatomija” (1973) graušana tiek skatīta kā sadistiska nežēlība un nekrofilisms. Taču Fromms izstrādā ne tikai harakteroloğiju, viňš iezìmē arī negatìvo un pozitīvo brīvību. ${ }^{30}$ Fromms uzskata, ka „pozitìvā brīvība ir visas, integrētās personības spontāna aktivitāte". ${ }^{11}$

Acīmredzot šajā saistībā Fromms laiku pa laikam atgādina par dzīvesmākslu jeb mākslu dzīvot, būt. Tā ir jo īpaši aktuāla tāpēc, ka mūsdienu biopolitiku raksturo princips: likt dzīvot un l̦aut nomirt. ${ }^{32}$ Tiesa, tas liek pārdomāt, kādās attiecībās Fromma risinājums ir ar šo biopolitiku. Taču, lai to varētu izdarīt, visupirms jātiek skaidrībā ar Fromma dzīvotmākslu. Bet tas nemaz nav tik vienkārši, jo viņš nepiedāvā izvērstu koncepciju, tās galvenā iezīme ir produktīva būšana jeb māksla mīlēt un domāt. Strādājot pie darba „Piederēt vai būt” (1976), Fromms izstrādā sagatavi „Soḷi uz būšanu”, kas tiek publicēta ar nosaukumu „Māksla būt”. Tajā Fromms raksta par pašpieredzi, pašanalīzi un pašattīstību, norādot, ka viņš raksta tikai par paša pieredzēto, piedzīvoto un pašvingrinājumiem. Fromms pat uzsver: „Kurš gaida, ka turpmākajā [izklāstā] sniegšu īsu ievadu, lai iemācītos mākslu dzìvot, labāk tūdal pat lai pārtrauc [lasīšanu]." "33 Viņš ieteic pievērsties dzīves meistariem un censties izprast viṇu teikto. Fromms piedāvā vien pārdomas par celiem un neceliem, ko apguvis no šiem meistariem.

E.. Fromms laikam varētu atkārtot Tenesija Viljamsa teikto, ka „būt brīvam nozīmē pašam veidot savu dzīvi”. ${ }^{34}$ Izklāstu Fromms sāk, uzskaitot šḳēršlus, kas atrodas ceḷā uz būšanu. Lielākais škēêrslis, vin,aprāt, dzīvotmākslas apguvē ir apgaismība, kas nodrošinājusi tikai ārējo atbrīvošanu. Tāpēc Fromms uzsver: „Vienīgais reālistiskais mērḳis ir totāla atbrīvošana; tas ir radikālā (jeb revolucionārā) humānisma mērḳis." ${ }^{35}$ Iekšējo atbrīvošanu 20. gadsimtā Fromms saskata psihoanalīzē un dažādās orientālās mācībās, kuras nereti tomēr kritizē. Brīvbūšanas šķērslis Fromma skatījumā ir triviālas sarunas un slikta sabiedrība. Trivialitāte ir tērgāšana, l̦aušanās banalitātei un virspusīgumam, nedzīvīguma pieḷaušana. Šādi tiek atstāts novārtā cilvēka galvenais uzdevums - „kḷūt piln̄̄gi piedzimušam" ${ }^{36}$ Savukārt slikta sabiedrība ir destruktīvas, nekrofilas orientācijas cilvēki. Fromms norāda, ka dzīve ir piepūle, bet modernais kuslais cilvēks no tās cenšas izvairīties. Viņu nomāc arī hroniskas bailes no sāpēm. Cits pašbūšanas šḳērslis ir bailes izskatīties autoritāram, centieni izvairīties 
no disciplīnas. Nereti antiautoritārisms ir narcistiskās paštîksmes racionalizācija. Fiktīvā brīvība īpaši spēcīgi izpaužas patērniecībā un aicinājumos uz kreativitāti, kas bieži vien noslēdzas ar pašpārdošanos.

Fromms piedāvā arī piecus priekšlikumus, kas iekḷaujas dzīvotmākslā. Pirmo priekšlikumu viņš ietver formulā „Gribēt vienu”, kas paredz izšķiršanos par noteiktu mērķi un nebūšanu nepiln̄̄gam. Cits priekšlikums ir saistīts ar vedinājumu būt nomodā, būt atvērtam un garīgi vitālam. Būšana nomodā sasaucas ar ieteikumu būt uzmanīgam, praktizēt koncentrētu uzmanību, vērīgumu. Cits vingrinājums ir koncentrēšanās. Fromms norāda: „Daudziem cilvēkiem ir bail koncentrēties, jo viṇi baidās pazaudēt sevi, ja l,oti ielaižas uz kaut ko citu, kādu ideju vai notikumu. Jo vājāka ir viṇu patība, jo lielākas bailes pazaudēt sevi, ja viṇi koncentrējas uz ko citu." ${ }^{37}$ Koncentrēšanās ietver arī l̦aušanos. Fromma pēdējais priekšlikums ir meditāciju praktizēšana, ko viṇš izprot kā nesaistītības (non-attachment) sasniegšanu. Savukārt psihoanalīzi Fromms skata kā pašpieredzi, ievingrināšanos pašanalīzē un tāpēc to dēvē par transterapeitisko psihoanalīzi, ${ }^{38}$ kurā tiecas uz labbūtību (well-being), neiluzoru dzìvi. Tiesa, psihoanalīze nodrošina iekšējo atbrīvošanos, izstumto konfliktu apzināšanos.

Pabeidzis darbu pie grāmatas „Cilvēka destruktivitātes anatomija”, Ē. Fromms 1974. gadā strādā pie manuskripta par Meistaru Ekhartu un Marksu (Meister Eckhart and Karl Marx on Having and Being), ko var uzskatīt par viņa dzīvotmākslas iezīmēšanu. Taču pamatojums ir problemātisks, kaut gan Frommam tas tā neškiet. Marksa sociālisms viṇa skatījumā ir profētiskā mesiānisma sekulāra izpausme, bet mērḳis ir ateistiski radikāls humānisms. ${ }^{39}$ Fromms atsaucas uz Marksa agrīnajiem darbiem un nesniedz norēķinu, ka principā Markss ir sociālā rasisma teorētiskais ciltstēvs. Acīmredzot svarīga ir ne tikai l̦aušanās, bet arī neḷaušanās. Acīmredzot nepietiek ar to, ka Markss "vedināja cilvēkus ne tikai citādi domāt un rīkoties, bet arī citādi $b u \bar{t} t .{ }^{40}$ Katrā ziņā, atsaucoties uz Marksu, 2o. gadsimtā dažādas sociālpolitiskas kustības nodrošina daudz vairāk nebūšanu nekā iespēšanu būt brīvam.

\section{Vēres}

I Šuvajevs I. Psihoanalīzes pēdas Latvijā. Rīga: LU Akadēmiskais apgāds, 20I2, 45., 205.lpp.

2 Fromm E. Gesamtausgabe. München: Deutsche Verlags-Anstalt, 1999, Bd. I, S. 217. Attiecīgā rindkopa sākas ar atziṇu: „Izceḷot psiholog̣isko apsvērumu nozīmi tagadējā 
lietu stāvoklī, negribu, lai šādi psiholog̣ija tiktu novērtēta par augstu." Priekšvārds sākas šãdi: „Šī grāmata ir dal̦a no aptveroša pētījuma, kurā skatīta mūsdienu cilvēka rakstura struktūra un psihologisko un sociologisko faktoru mijiedarbỉbas problēma.”

3 „Šajā nodaḷā gribu iztirzāt tikai kulturāli signifikantos mehānismus." (Fromm E. Op. cit., S. 300.)

4 Ilgstošā laika koncepts ir saistīts ar tā saukto franču jauno historiogrāfiju (esmu mēgénājis iezīmēt tās aprises un risināmo problemātiku, sk.: Parizes intervijas. Rīga, 1993, 130.-152. lpp; Šuvajevs I. Prelūdijas. Rīga: Intelekts, I998, I68.-ı97. lpp.). Ilgstošais laiks tiek attiecināts nevis uz gandrīz nekustīgo vēsturi, bet gan uz lēnās elpas vēsturi, ja izmanto F. Brodēla izteikumu. Piedāvāto pārdomu ietvarā šĩ elpa aizsākas ı 8. gadsimtā.

5 Estergrēns K. Džentlmeņi. / Tulkojusi Rute Lediņa. Rīga: Zvaigzne, [2008], 220. lpp.

6 Fromm E. Op. cit., S. 236.

7 Braudel F. Grammaire des civilisations. Paris: Flammarion, 2013, p. 447.

8 Savulaik jau to esmu aplūkojis, tāpēc šeit piedāvāju īsu rezumējumu (sk.: Šuvajevs I. Prelūdijas. Rīga: Intelekts, 1998, 50. lpp. un tālāk; tekstā pieminētā brīvības kā važu uztveršana - 57.lpp.). Tolaik piedāvāju sava veida figurālu skatījumu, neminot attiecīgās personas. Acīmredzot tā bija kḷūda, kaut arī darba apjoms būtu krietni pieaudzis un izraisījis konfrontācijas.

9 Sk.: Mauss M. Sociologie et anthropologie. Paris: PUF, 1993, p. XXV ff.

ı Par muskulatūru un orgāniem sk.: Мамардашвили М. Опьıт физической метафизики. Москва: Прогрес-Традиция, 2009, с. 86, 90.

II Runa ir par ambivalenci noteiktās varas attiecībās, to transformēšanu, pieḷaujot jaunu hierarhijas veidošanu un vairojot neapzinātību. Sk.: Šuvajevs I. Psihoanalizze un dzives mäksla. Rīga: Intelekts, 1998, 95.-98. lpp.

I2 Sk.: Apvērsums. 1934. gada I5. maija notikumi avotos un pētījumos. Sast. V. Ščerbinskis, Ē. Jēkabsons. Rīga: Latvijas Nacionālais arhīvs, 20ı2; Hanovs D., Tēraudkalns V. Laiks, telpa, vadonis: autoritārisma kultūra Latvijā 1934-1940. Rīga: Zinātne, 2012.

I3 Zelče V. „Bēgšana no brīvības”: Kārḷa Ulmaṇa režīma ideologiija un rituāli. Agora 6 (Reiz dzīvoja Kārlis Ulmanis...). Rīga, 2007, 348. lpp.

I4 Zellis K. Ilüziju un bailu mašinèrija. Propaganda nacistu okupètajā Latvijā: vara, mediji un sabiedrība (194I-1945). Rīga: Mansards, 2012, 196. lpp. Tā ir atsauce uz Frommu, diemžēl citādi šajā darbā Fromma atziṇas netiek izmantotas.

I5 Sk.: Snaiders T. Asinszemes. Rīga: Jumava, 2013.

I6 Ieskatu šajā problemātikā saistībā ar Frommu var gūt Rainera Funka grāmatā: Funk R. Ich und Wir. Psychoanalyse des postmodernen Menschen. München: dtv, 2005.

I7 Plašāk sk.: Wolff L. Inventing Eastern Europe. The Map of Civilization in the Mind of the Enlightenment. Stanford: Stanford University Press, 1994.

I8 Fromm E. Gesamtausgabe. Bd. I. München: Deutsche Verlags-Anstalt, I999, S. 377. Norēķinu par šādiem iluzoriem skatījumiem ir centies sniegt Fransuā Firē. Sk.: Furet F. La passe d'une illusion. Paris: Laffont, 1995.

I9 Sk.: Feldmanis I. Vācbaltiešu izcel̦ošana no Latvijas (I939-I94I). Rīga: LU Akadēmiskais apgāds, 2012. 
20 Šuvajevs I. Filosofija kā dzīvesmāksla. Rīga: Zvaigzne ABC, 2007, 94.-107. lpp.

2I Эткина А. Внутренняя колонизация. Имперский опьт России. Москва: Новое митературное обозрение, 2013, с. 13 (Internal Colonization. Russia's Imperial Experience, 20II).

22 Могильнер М. Ното ітретіi. История физической антропологии в России. Москва: Новое митературное обозрение, 2008, с. 237 и А. Sk. arī: Авдеев В. Расология. Москва: Белые альфы, 2005; Савельев А. Образ врага. Расология и политическая антропология. Москва: Бемые амьфы, 2007.

23 Sk.: Kammerer D. Bilder der Überwachung. Frankfurt/M.: Suhrkamp, 2008.

24 Literāru atveidi sk., piemēram, Klāsa Estergrēna romānos Džentlmeņi (Rīga: Zvaigzne, [2008]); Gangsteri (Riga: Zvaigzne, [2008]).

25 Sk.: Liessmann K. P. Theorie der Unbildung. Die Irrtümer der Wissenschaftsgesellschaft. München: Piper, 2009 .

26 Sk., piemēram: Crouch C. The Strange Non-Death of Neoliberalism. Cambridge: Polity Press, 20II.

27 Šuvajevs I. L,eṇins: vārdi un darbi. L,eṇins V. I. Valsts un revolūcija. Rīga: Zvaigzne ABC, [2011], 5.-I6.lpp.

28 Sk.: Šuvajevs I. Agambens un biopolitika. Kentaurs XXI, Nr. 49, 2009, 66. lpp.

29 Sk.: Šuvajevs I. Dzīlu psiholoğija. Personas, idejas un risinājumi. Rīga: Zvaigzne ABC, 2002, 193. lpp.

30 Šis noškīrums dažkārt ir ticis salīdzināts ar Jesajas Berlina veikto nošķ̄irumu esejā „Divi brīvības jēdzieni” (Berlins J. Četras esejas par brīiību. Rīga: Sprīdītis, 2000, 167.-216.lpp.). 1958. gadā aizsāktajā darbā gan Berlins nepiemin Frommu. Berlins piemin Benžamēnu Konstānu (1767-1830), kurš jau ir rakstījis par pozitīvo un negatīvo brīvību kā liberté des anciens un liberté des moderns. Bet Berlins nepiemin Imanuela Kanta (1724-1804) veikto nošķīrumu: pozitīvā un negatīvā brīvība, tās pozitīvais un negatīvais jēdziens. Kants to piedāvā I785. gadā Rīgā publicētajā darbā „Tikumu metafizikas pamatojums”.

3I Fromm E. Gesamtausgabe. Bd. I. München: Deutsche Verlags-Anstalt, 1999, S. 368.

32 Foucault M. „Il faut défendre la société. Paris: Gallimard, 1997, p. 214.

33 Fromm E. Gesamtausgabe. Bd. I2. München: Deutsche Verlags-Anstalt, 1999, S. 400.

34 Viljamss T. Atmiñas. / Tulkojusi M. Andersone. Rīga: Atēna, 2008, 228. lpp.

35 Fromm E. Op. cit., S. 400.

36 Ibid., S. 409.

37 Ibid., S. 426,

38 Ibid., S. 433.

39 Ibid., S. 503. Par sekulāro izpausmi - S. 485.

40 Ibid., S. 508. 
Fromms psihoanalīzes un filosofijas kontekstā 

leva Stūre-Stūriņa

\section{Bēgšanas mehānismi un nāves dziṇa: sadomazohisms un destruktivitāte}

Ēriha Fromma pētniecības izstrādnes iezīmē psihoanalīze un marksisms. Fromms aplūko cilvēka iedabas un sabiedrības rakstura un brīvības un bēgšanas mehānismu problemātikas saistību savā pirmajā monogrāfijā Bēgřana no brivīibas (Escape from Freedom; Gesamtausgabe, 194I), kas turpmāk tiek pārpublicēta ar nosaukumu Bailes no brìvības (Fear of Freedom). Rakstā piedāvātās pārdomas ir mēǵinājums parādīt Fromma aplūkoto bēgšanas mehānismu saistību ar Freida psihoanalīzes izstrādnēm par dziṇnisko, nāves dziņu. Ar Fromma izstrādnēm par destrukciju iespējams papildināt un citādi interpretēt agresijas problemātiku un mazohisma ekonomisko problēmu, primāro mazohismu. Fromms atsaucas uz Freida izstrādnēm par nāves dziṇu, agresiju un destrukciju, taču nenorāda un neatsaucas uz konkrētiem darbiem, pasāžām. Šis apsvērums ir jānnem vērā, jo arī Freida domas par dziņu mācību un nāves dziņas problemātiku ir mainījušās.

$\bar{E}$. Fromms, izmantojot un vienlaikus norobežojoties no Freida izstrādnēm par nāves dziņu un sadomazohismu, pievēršas jautājumam par cilvēka agresivitāti, saistot to ar brīivibas problemātiku un bēgšanas no brīvības mehānismiem. Ė. Fromms aplūko dažādus bēgšanas mehānismus, pievēršoties tiem, kas ir ne tikai psiholog̣iski, bet arī sociālkulturāli nozīmīgi: bēgšanu autoritārismā, destrukciju jeb graušanu un automatizējošo konformismu, kurus attiecina uz fašisma un demokrātijas sociālo procesu dinamiku. Freids darbos Laikmetīgi par karu un nāvi un Käpēc karšs? jau pievērsies psiholog̣isko 
norišu saistībai ar politisko un sociālo procesu dinamiku, konkrētāk, indivīda un sabiedrības agresijas problemātikai. Viňš pievēršas interpersonālām attiecībām rakstura pētniecībā. Raksturā savijas individuālā un sabiedriskā izturēšanās. Indivīda raksturs veidojas attieksmē pret pasauli, sabiedrību un tās procesiem, citiem cilvēkiem un arī attieksmē pret sevi. Rakstura izveidošanos ietekmē gan ekonomiskie un sabiedriskie spēki, gan psihiskie spēki un vajadzības, tādēḷ cilvēka raksturs nav tikai dzimumdziṇu un pašuzturēšanas, bet arī agresesijas dziṇu ietekmju rezultāts. Tādējādi Fromms atsakās no dziņu mācības un no libido teorijas. Viņš ievieš sabiedrības libidozas struktūras konceptu, tomēr vēlāk izmanto jēdzienu „sabiedrības raksturs”, tātad Frommu vairāk interesē nevis individuālais, bet gan sabiedriskais raksturs. ${ }^{1}$ Bēgšanas mehānismu, kas ir saistīts ar mācību par raksturiem, izstrādnes E. Fromms turpinājis darbos Cilvēks pats sev (Man for himself, 1947), Veselā sabiedrība (The Sane Society, 1955) un Cilvēka destruktivitātes anatomija (The Anatomy of Human Destructiveness, 1973).

$\bar{E}$. Fromms, pievēršoties bēgšanas no brīvības mehānismiem, izmanto Freida atziņas par nāves dziņu, sadismu un mazohismu. Paša kā indivīda, proti, vienpatnas, no citiem atšķirīgas un nošķirtas esības apjausme izraisa nedrošību un bailes. Bēgšanas motīvs, kas var būt neapzināts, ir indivīda izolācijas, vienatnības, atsvešinātības un bezspēcības izjūtas. Bēgšana tiek saistīta ar mazvērtību, nenozīmību, nedrošîbu un nepatstāvību, kas ārpasaules priekšā rada bailes. Bailes izraisa bēgšanu, bēgšanu no brīvības, tāpēc iespējams teikt - tās ir bailes no brīvības vai pat pats brīvības apjēgums, pārdzīvojums, izjūta rada bailes. Nedrošības pārņemts cilvēks bēg no brīvības un arī no sevis. Nāves dziņas darbību var saitīt ar veidiem - kā cilvēks mēgina aizbēgt, novērsties no neapmierinošās realitātes. Realitāte rada konfliktu starp Es un dziṇu pretenzijām, vēlmēm. Freids, runājot par neapmierinātību un īgnumu kultūrā, norāda, ka „dzīve, kāda tā uzlikta, mums ir pārāk smaga; tā mums rada pārāk daudz sāpju, vilšanos, neatrisināmu uzdevumu. Lai to izturētu, mēs nevaram iztikt bez remdināšanas līdzekliem. (Teodors Fontāne mums ir teicis: „Nevar iztikt bez palīgkonstrukcijām.”) Šādi līdzekḷi acīmredzot ir triju veidu: spēcīga novēršanās, kas l̦auj nevērtēt tik augstu mūsu postu; aizstājapmierinājumi, kas to mazina; apreibināšanās līdzekḷi, kas mūs dara pret to nejūtīgus. Kaut kas tāds vienmēr ir nepieciešams." Dzīve cilvēkam ir uzlikta, tā nav paša izvēlēta, taču $k \bar{a}$ dzìvot, ir jautājums 
sev pašam. Ir dažādi bēgšanas mehānismi, lai aizbēgtu, novērstos no atraidošās realitātes - pārveidojot to fantāziju projekcijās, dažādiem līdzekḷiem apreibinoties un galu galā aizbēgot no iespējas būt pašam, paḳlaujoties un tādējādi arī iekḷaujoties kultūras sociālajās grupās. Tas gan nozīmē novēršanos no realitātes, tās aizstāšanu saistīt ar bēgšanu. Kultūras mērkikis nav darīt indivīdu laimīgu. Laimīga būšana ir paša indivīda problēma, rēḳinoties ar vēlmju pretenzijām un ārpasaules nosacījumiem. Laimīgs var kḷūt tikai pats, par laimīgu nevar padarīt kāds cits. Cits var ietekmēt dažādu izjūtu rašanos, taču tas ir paša pārdzīvojums. Kas gan ir laime? Labāk runāt par patiku, tīksmi, kas neparedz tikai īslaicīgu jušanu, izjūtu, bet var arī raksturot paša būšanu, t.i., apmierinātības (gan psihiskas, gan k̦ermeniskas) līmenī. Indivīda tendencei gūt tīksmi jāsastopas ar dažādiem šķērṣ̌̆liem, proti, tîksmes princips ārpasaules ietekmē modificējas par realitātes principu, kas rēḳinās ar ārpasaules nosacījumiem. Indivīdam „ciešanu novēršanas uzdevums visnotaḷ vispārīgi izstumj tīksmes ${ }^{3}$ gūšanu otrajā plānā” ${ }^{4}$ Šo atsacǐšanās ceḷu iet, pakḷaujoties realitātes prasībām, ierobežojumiem, aizliegumiem, tiecoties savaldīt dziṇas, taču tas nenozīmē atteikties no to apmierināšanas. Kultūra prasa lielus upurus ne tikai seksualitātei, bet arī cilvēka agresīvajai nosliecei, tādēl saprotams, kāpēc cilvēkam kḷūst grūti justies laimīgam. Freids norāda, ka „kultūras cilvēks daḷu laimes, iespējams, apmainīja pret dalıeju drošību” Apmierinājuma pretenzijas vietā nostājas drošības garantijas. Tomēr ir iespējamas arī situācijas, kad nevis tīksmes gūšanas meklējumi ir ārēji aizliegti vai ierobežoti, bet gan pats indivīds ir frustrēts savās darbībās, t.i., viņ̌̌ nespēj l̦aut sev tiekties pēc apmierinājuma. Laimīga būšana ir paša uzdevums, kurā ir jāievingrinās, taču ir nepieciešama drosme būt pašam un paša brīvība, ko nevar aizstāt ar dažādām brīvībām.

E. Fromms runā par pastāvošo sabiedrību, kas ir pretēja cilvēka pašrealizācijai (arī laimei). Laimes jautājums tiek aizstāts ar cilvēka normalitāti, veselumu, taču runa ir par indivīda integritāti kultūrā, proti, spēju līdzdarboties sabiedrībā un reproducēties, veidot ǵimeni. Tādējādi ir robežškirirtne starp indivīda eksistenci kultūrai un paša eksistences pārdzīvojumu, kur otrās mērķis ir - brīvība, lai pašīstenotos. Indivīds, kas ir normāls, proti, labāk adaptējies sabiedrības prasībām, nebūt nenozīmē, ka ir vesels, skatoties no cilvēka vērtību prizmas. Fromms norāda, ka neirotiska persona var būt raksturojama kā tāda, kas nav bijusi pavisam gatava padoties cīṇā par sevi. 
Tā vietā, lai sevi izpaustu produktīvi, neirotiķis meklē glābšanu, kas izpaužas kā neirotiski simptomi un no atraidošās realitātes aizbēg fantāziju pasaulē. Tomēr, skatoties no cilvēka vērtību skatpunkta, neirotiķis ir mazāk kropls par normālo, kas ir pavisam zaudējis individualitāti. ${ }^{6}$ Bēgšana no brīvības paredz arī sevis zaudēšanu - individualitāti aizstāj normalitāte.

$\bar{E}$. Fromms runā par pozitīvo un negatīvo brīvību. Negatīvā brīvība ir brīvība no ārpasaules spaidiem, ierobežojumiem, aizliegumiem utt. Pozitīiā brīvība ir brīvība, lai realizētu cilvēcību patības nozìmē, būtu pats. Iegūt 'brīvību no' (freedom from), brīvības no ierobežojumiem, autoritātes, dogmām ir viens aspekts, taču pavisam kas cits - būt gatavam 'brīvībai uz' (freedom to). Politiskās, ekonomiskās vai sociālās brīvības notuše paša brīvību. Vai cilvēks ir gatavs brīvībai būt pats? Kāda gan jēga, piemēram, no runas brīvības, ja pats nav brīvs? Var teikt arī tā, ka brīvības var īstenoties tikai tad, ja to pamatā ir paša brīvība. Indivīds saprot, ka pats un ārpasaule ir atškirtas, nošķirtas vienības. Būt pašam paredz - būt vienam, tas rada bažas, nedrošỉbu, bailīgumu. Indivīds ir viens pats savas brīvības priekšā. Indivīds var būt nebrīvs sevī, pat ieguvis dažādas ārējās brīvības. Ārējās brīvības ir tās, ar kuru atṇemšanu draud, lai indivīds būtu paklausīgs, un, būdams paklausīgs, tas ir paklauts. Tomēr brīvība nav tikai psihologiska, iekšêja, tā aptver visu indivīda patību un īstenojas darbībās, praksēs, aptver dzīves devumu. Brīvību praktizēšana patīgi nav iespējama bez paša brīvības. Pēc vienpatnuma stāvokḷa apjēgšanas, lai pārvarētu atškirtîbas, bezspēcības, vienatnības izjūtu, ir iespējami divi ceḷi - pozitīvā brīvība vai bēgšana no brīvības. Pozitīvā brīvība ir paša „spontāna” aktivitāte - emocionāla, sajūtu un intelekta dotumu realizēšana, t.i., individuālā paša kultivēšana un šĩ pašizpausme rada arī rūpes, cieṇu un mîlestību pret otru, citu. Lai mīlētu citus, ir jāmīl sevi.

Bēgšanas mehānismi veidojas kā izolētā, vienpatn̄̄gā indivīda reakcija uz nedrošības un bezspēcības izjūtām. Bēgšana no brīvības ir atteikšanās no brīvības. Bēgšana no sevis paša ir atteikšanās no individualitātes. Lai aizbēgtu no vienpatnības un bezspēcỉbas, cilvēks ir gatavs tikt vaļă, atbrīvoties no sevis paša, t.i., kḷūt ne-Es, lai justos pasargāts un drošāk. Saskaṇā ar Fromma domām, bēgšanai no brīvības ir uzmācības iezīme. ${ }^{7}$ Uzmācīgā atkārtošanās ir viens no psiholog̣iskajiem nāves dziṇas pamatojumiem (līdzās mazohisma un sadisma un ambivalences fenomeniem). Fromms, neatsaucoties, bet izmantojot Marksa izstrādnes par 'atsvešinātību', norāda, ka cilvēks jūtas 
atsvešināts ne tikai no citiem, bet vispirms no sevis. Tā ir subjekta saškeltīiba. Fromms, aplūkojot bēgšanas no brīvības mehānismus, sasaucas ar Freida izstrādnēm par neapmierinātību kultūrā, jo runa ir par patības, eksistences tehniku īstenošanu un nevis par bēgšanu no patīgā.

Vai cilvēks primāri ir tendēts būt pašdestruktīvs un nevis agresīvs, ir jautājums, kas tiek risināts saistībā ar to, vai primārs ir mazohisms vai sadisms un vai to primaritāte neizbēgami jāsaista ar tendenci uz pašdestrukciju vai agresiju pret citiem? Jautājums iekḷaujas Freida izstrādnēs par nāves dziņu, postulējot primāro mazohismu. Freida dziņu mācība piedzīvo transformāciju. Pirmajā dziṇu mācībā ir runa par seksuālajām dziṇām un Es jeb pašuzturēšanas dziņām. Otrā dziṇu mācība, kura tiek ievadīta darbā Vinpus tīksmes principa (Jenseits des Lustprinzips, 1920), tiek postulētas dzīves dziņas jeb Eross un nāves dziṇa. Pirmās dziņu teorijas laikā, darbos sadomazohisms ir pieskaitīts perversiju klasei (Trìs apcerējumi par seksuālā teoriju; Drei Abhandlungen zur Sexualtheorie, Igos) un sadisms ir primārs, proti, mazohisms tiek atvasināts no sadisma, kas rodas dziņu atvairīšanas mehānisma „apvēršanas pretstatā”, no aktīva uz pasīvu un „vēršanās pret paša Es” rezultātā. Otrās dziṇu mācības darbos ir otrādi, mazohisms ir primārs un sadisms tiek atvasināts no tā.

Ir iespējami vairāki bēgšanas mehānismi, kas norāda ne tikai no kā bēg, bet arī uz kurieni bēg. Piemēram, bēgšana no atmiṇām, pārdzīvotā, no sevis un bēgšana miegā, slimībā, pašnāvē, autoritārismā. Bēgšanas mehānismos runa ir par bezapziņas spēkiem, kas rod izpausmi „racionalizāzijā”, t.i., sekundārā apstrādē, un izpaužas kā rakstura iezīmes. Bēgšana var būt neapzināta. Fromms darbā Bēgšana no brīuības pievēršas ne tikai autoritārisma mehānismam, bet runā arī par autoritāro raksturu. Sabiedrisko procesu izpausmes ir cieši saistītas ar psihologiskiem procesiem, kas norisinās indivīdā - psihologíiskais izpaužas indivīda darbībās un sociālajās praksēs. Cilvēka darbību motivācija var būt neapzināta, taču viņš tic, ka tie ir viṇa motīvi, kas liek darboties, just, uzskatìt to, ko uzskata (to var nosaukt par brīvās gribas ilūziju, ja par analog̣ijas pamatu n,em Freida izstrādnes cīnā pret dažādām, piemēram, reliğijas, ilūzijām).

Autoritārisma bēgšanas mehānisms jeb bēgšana autoritārismā, ir tendence atdot pašam savas individualitātes neatkarību un sakausēt pašam sevi ar kādu vai kaut ko ārpus sevis, lai iegūtu spēku, kas pašam trūkst. ${ }^{8}$ 
Autoritārisms ir nevis kāda cilvēka īpašība vai pozīcija, bet gan tas apzīmē savstarpējas attiecības, kur viena persona uzlūko otru kā pārāku. ${ }^{9}$ Tomēr autoritārisms norāda arī uz to cinnu par varas attiecību noturēěanu vai apgriezenisku pārmaiṇu, proti, sadisma un mazohisma pārmaiṇu. Autoritārās attiecībās iekḷaujas cilvēka jūtu dzìves ambivalence, t.i., vienlaicīgs naids un mīlestība pret valdnieku, līderi. Indivīds apbrīno un pakḷaujas autoritātei, taču vienlaikus (apzināti vai neapzināti) grib būt tāds kā viṇš - pats būt autoritāte, kurai citi paḳ̂aujas, tādējādi tiek izjusts naidīgums, skaudība. Autoritāte var būt gan ārēja, gan iekšēja, piemēram, pienākums un Virs-Es, tā var būt arī anonīma. Anonīma vara parādās kā veselais saprāts, zinātne, normalitātes vai psihiskās veselības diskurss. Tā ir patstāvības, neatkarības (nav nepieciešami runāt par sasniegtā stāvokḷa regresiju, bet gan par iespēju, potencialitāti, büt sev - nerealizēšanu) atmešana. Bēgšanas no brīvības psihologiskais mehānisms var izpausties kā sadomazohistiska tendence - pakḷaut vai pakḷauties. Mazohisms un sadisms ir autoritārisma piemērs, kas parādās kā pakḷaušanās un dominēšanas jeb pakḷaušanas mijiedarbība. Fromms sadismu un mazohismu skata kā agresivitātes divas izpausmes, tādējādi sekojot Freida izstrādnēm par nāves dziņu.

$\overline{\mathrm{E}}$. Fromms mazohismu saista ar bezspēcības, bezpalīdzības, nepilnvērtības un niecīguma izjūtām. Mazohists tiecas paḳlauties un piederēt kaut kam varenākam un spēcīgākam, piemēram, priekšniekam, līderim, dieviem, institūcijām vai liktenim, arī sirdsapziņai, Virs-Es. Fromms pievēršas morālajam mazohismam, ko Freids ir aplūkojis rakstā Mazobisma ekonomiskā problèma (Das ökonomische Problem des Masochismus, 1924). Lìdzīgi kā tiek runāts par morālo mazohismu, var runāt par morālo sadismu, kur abu mērḳis ir nevis ciešanas un sāpes, bet gan pasivitāte pakḷaujoties vai aktivitāte - dominēt, padarīt atkarīgu, instrumentalizēt, ekspluatēt, pārvaldīt, likt ciest, pazemot, kas nav jāsaista ar seksualitāti. Gan mazohists, gan sadists paredz atkarību (Fromms lieto jēdzienu „simbioze”), proti, pārvaldītājs vai mocītājs ir atkarīgs no pārvaldāmā vai mocāmā. Gan sadisma, gan mazohisma gadījumā ir iespējama identificēšanās ar mocāmo vai mocītāju. Cilvēks ir nevis mazohists vai sadists, bet gan cilvēka iedabā ir agresija, kas var izpausties gan kā sadisms, gan kā mazohisms, turklāt izpausmes var pārmainīties. Gan mazohists, gan sadists ir atkarīgs (kas var atklāties kā sadomazohistiska mìlestība) no ārpasaules objekta, tomēr arī šì atkarība, īpaši sadisma gadījumā, 
var būt neapzināta. Sekojot Freida atzin̄ām, Fromms izmanto nostāju, ka sadisms un mazohisms ir viens fenomens, turklāt par bēgšanas mehānismu pamatu liekot mazohistisko raksturu (līdzīgi kā Freids, postulējot primāro mazohismu) - patstāvību aizstājot ar atkarību. Visiem mazohista centieniem un darbībām ir viens mērḳis - zaudējot sevi, atbrīvoties no individuālā sevis, citiem vārdiem sakot, atbrīvoties no brīvības robežas. ${ }^{10}$ Tie ir centieni atbrīvoties no paša bezspēcīguma izjūtas, pakḷaujoties kam spēcīgākam ārpus sevis. Runa ir par piederību, integritāti, drošības izjūtu Es bezspēcỉbas vietā. Fromms norāda, ka, „kamēr es cīnos starp savu vēlmi būt neatkarīgam un spēcīgam un manu nenozīmības vai bezspēcības izjūtu, es esmu noķerts mokošā konfliktā. Ja man veicas, reducējot savu individuālo sevi uz neko, ja es varu pārvarēt savas atšķ̧irtības kā indivīda apzināšanos, es varētu glābt sevi no šī konflikta"11. Bēgšana no brīvības ir centieni atrisināt konfliktu starp vēlmi būt pašam un savas bezspēcības, vienpatnības apzināšanos. Mazohista mazvērtības izjūtā, paššaustī̌̌anā var saskatīt nepatīgu vēlmi vēl vairāk radīt mazvērtīguma, nenozīmības izjūtu un galu galā iznīcināt pašam savu individualitāti un vienpatnību. Arī pašnāvība var būt bēgšana no vienpatnības.

Morālais mazohisms ir cieši saistīts ar automātisko konformismu. Angḷ valodas vārds 'conformity' jēdzieniski norāda uz saskaņu, atbilstību un pakḷaušanos. Automātiskais konformisms ir pseido - domāšana, izjūtas, vēlmes, griba. Tā ir atteikšanās no sevis un atzītās, vispārpien,emtās personības parauga iekškīigošana. Fromms norāda, ka „ja indivīds atrod kultūras paraugus, kas apmierina mazohistiskos centienus (kā padevība „līderim” fašisma ideologijāā), viņš iegūst kādu drošỉbu, atrodot sevi vienotu ar miljoniem citu, kas dalās šajās izjūtās" ${ }^{12}$. Indivīdi savstarpēji savā Es identificējas ar vadoni, līderi, tādējādi aizbēgot no bezspēcības (ja ārējiem spēkam pakḷaujas, tas aizsargās) un vienpatnības izjūtas. Caur identificēšanos indivīdi libidiozi ir savstarpēji saistīti. Fromms norāda, ka izstumšanas rezultātā patīgā vietā rodas pseidoizjūtas, tādējādi pieškłirot 'izstumšanai' jaunu nozīmi, proti, „ikviena izstumšana likvidē īstā paša daḷas un uzspiež pseidoizjūtu aizvietošanu ar to, kas tika izstumts" ${ }^{\prime 3}$. Izstumšanu veic Virs-Es vai tā uzdevumā Es. Pseido-domas ir Virs-Es integrētas. Jo vairāk izplešas Virs-Es, jo Es kḷūst nepatīgāks. Es ietver citu, svešo, ne-Es, taču šis ne-Es veidots pēc „līdzības” ar visiem un nevienu. Es ir masas Es, precīzāk - Es ir Mēs. No brīvības, no individuālisma noris bēgšana masā un autoritārismā. Tādējādi saskaṇā ar 
Fromma domām, izstumšana nepilda tikai aizsardzības, atvairīšanas funkciju, bet arī aizvietošanas funkciju. Paša domāšanas, izjūtu, vēlēšanās aktu aizvietošana ar pseidoaktiem noved pie „sevis aizvietošanu ar pseidosevi” ${ }^{14}$. Pseido-personība ir tikai reprezentācija lomai, kuru indivīdam ir jāpilda. Indivīds lomu pilda it kā tā būtu paša vēlme un griba. Pseido Es ir Virs-Es ideālveidojums, ar kuru Es sevi samēro un pēc kura tiecas. Indivīda automatizācija radījusi nevis gaidīto drošības izjūtu, integritāti, bet vēl vairāk bezpalīdzību un nedrošumu. Tā ir nemitīga tiekšanās atbrīvoties no sevis, no atbildības, būt kādam citam, kas iekḷaujas pulkā, kur visi ir līdzīgi visiem, kas veidoti pēc paraugiem. Indivīds ir gatavs pakḷauties arvien jaunām autoritārisma formām, ideologijām, ja vien tās nāk ar drošỉbas, neapšaubāmības solījumu. Tie ir nevis centieni atbrīvoties, bet tā ir aizstāšana.

Fromms līdzās autoritārismam, proti, sadomazohisma saspēlei, un automātiskajam konformismam, izvirzot vai no tiem atšķeļot destruktīvismu jeb graušanu, principā iebilst Freida domai, ka nāves dziņas izpausmes, ja tās nav ar dzīves dzin̄ām erotiski legēetas, nav saskatāmas savās graušanas dusmās. Destruktivitāte ir ārpasaules graušana, lai mēginātu glābt sevi. Destruktivitātes mērķis ir nevis simbiotiskas attiecības (kā tas ir sadomazohismā) ar objektu, bet gan objekta iznīcināšana, graušana. Saskaņā ar Frommu destruktivitāte, vai nu vērsta pret ārpasaules objektu vai pašu, ir nesaistīta ar seksuālo. Destruktivitāte nav identiska ar sadomazohismu.

Frommu neapmierina Freida izstrādṇu par 'nāves dziṇu' biologiskais pamatojums. ${ }^{15}$ Biologiskā hipotēze ir svarīga mazohisma primaritātes izvirzīšanai. Nāves dziṇas pamatojums balstās gan biologijas hipotēzēs, dziṇas konservatīiajā raksturojumā, gan uzmācīgās atkārtošanās fenomenā, gan sadomazohisma fenomenā un ambivalences fenomenā. Fromms nāves dziņu vispirms attiecina uz destrukciju, kur tā parādās bez seksuālā legéejuma, tādējādi nošķirot no sadomazohisma. Destruktivitātes daudzumam, vai nu tā būtu vērsta pret ārēju objektu vai sevi pašu, būtu jābūt konstantai. Saskaņā ar Fromma atziṇu, destruktivitāte atšķiras gan indivīdos, gan dažādās sociālās grupās, piemēram, destruktivitātes līmenis zemākajos sociālajos slān,os ir augstāks. Destruktivitāte nav iedzimta visiem indivīdiem vienādā mērā, konstanti (vismaz ekonomiskajā aspektā ne).

$\bar{E}$. Fromms apgalvo, ka dzīves un nāves dziņa darbojas ar vienu enerğiju. ${ }^{16}$ Destrukcijas enerğija ir energija, kas tika virzìta uz dzīves (dziņas) mērķiem, 
taču tika sadalīta un pārmainījās enerğijā, kas ir vērsta uz destrukciju. Tādējādi Fromma izstrādnēs nav runa vairs par dzìves un nāves dziṇu vienlaicīgu līdzāspastāvēšanu, bet gan transformāciju no dzīves dziņas enerğijas par destrukciju. Taču jau Freids, risinot jautājumu par nāves dziņas enerğiju, darbā Viņpus tīksmes principa norādīja, ka metapsihologijas jautājumu nenoteiktība ir attiecināma uz to, ka „mēs neko nezinām par uzbudinājuma procesa iedabu psihiskās sistēmas elementos un nejūtamies tiesīgi izvirzīt par to kādus pieņēmumus. Tādējādi mēs nemitīgi operējam ar lielu X, kuru pārṇemam ikvienā jaunā formulā" ${ }^{17}$. Darbā İgnums kultūrā Freids norāda, ka jēdziens „libido” tiek attiecināts uz Erosa spēka izpausmēm, lai nošķirtu to no nāves dziñas, kuru „tikai nojaušam kā atlieku aiz Erosa un nemanām tur, kur tā nenodod sevi leǵejumā ar Erosu”. Turpat Freids pievieno piezīmi, ka „mūsu tagadējo izpratni var izteikt gandrīz vai vienā teikumā: jebkurā dziņas izpausmē piedalās libido, taču ne viss tajā ir libido"18. Tādējādi tiek norādīts, ka dzīves un nāves dziņai ir dažādas enerǵijas. Iespējams, varētu apgalvot, ka dzīves dziņa darbojas ar libido energijiju, bet nāves dziņai ir cita enerğija - daḷa no nenotveramā X. Darbā Es un Tas Freids, skaidrojot, kā iespējama atvairī̌sanas mehānisma apvēršana pretstatā, proti, no mīlestības naidā, pauž pien,ēmumu, ka psihiskajā aparātā, Es vai Tas veidojumā, eksistē kas tāds kā pārvietojamā enerǵija (displaceable energy), kas ir sevī nenoteikta, bet var tikt pievienota kvalitatīvi atšķirīgajām erotiskajām vai destrukcijas ierosām. ${ }^{19}$ Tādējādi Fromma izstrādnes varētu aplūkot saistībā ar ideju par pārvietojamo, pārveidojamo enerǵiju. Taču tad nesaprotams kḷūtu apsvērums, ka libido mēgeina neitralizēt nāves dziņas enerğiju, proti, „libido uzdevums ir padarīt nekaitīgu šo destruktējošo dziņu, ko arī izdara, novirzot to lielākoties ar īpašu orgānu sistēmu - muskulatūru - uz āru, pret ārpasaules objektiem. Tad to sauc par destrukcijas dziṇu, dziṇu sagrābt savā varā, gribu pēc varas". ${ }^{20}$ Ja ir runa par nāves dziņas savaldī̌anu, saglabātos iespēja, ka destrukcija vispirms tiek vērsta uz āru, taču būtu pretrunā ar apsvērumu, ka destrukcija ir dzīves dziņu enerğijas transformācija.

Fromms nerunā par dzìves un nāves dziṇu cīṇu, neatkarīgu līdzāspastāvēšanu, jo pirmais ierobežojums rada destruktivitāti, principā - naidīgumu pret ierobežojošo. Fromms norāda, ka „destruktivitāte ir nedzīvotās dzīves rezultāts" 21. Tas nozīmē, ka enerǵija, kuru varētu iztērēt dzìves dziņas mērķu sasniegšanai vai apmierināšanai, destrukcijas kalpībā vēršas pret pašu 
dzīvi. Dzīves dziņas apspiešana rada destruktivitāti. Tomēr var norādīt, ka šāda interpretācija no jauna aktualizē Freida pirmās dziṇu mācības ietvaros postulēto sadisma primaritāti. Pirmajā dziṇu teorijā sadims un mazohisms ir seksuālo dziṇu komponenti. Mazohisms rodas atvairī̌̌anas mehānisma „vēršanās pret paša Es” rezultātā, proti, dziņas enerğijas piesaistīšana, padarot Es par objektu. Darbā Dzingas un to liktenis (Triebe und Triebschicksale, IgIS) Freids pauž nostāju par sadisma primaritāti, t.i., ka mazohisms ir patiesībā sadisms, atpakal, vērsts pret subjekta paša Es. ${ }^{22}$

$\bar{E}$. Fromma izstrādnes par bēgšanas mehānismiem būtu labāk saprotamas un sniegtu jaunu perspektīvu, ja destrukciju viņš būtu problematizējis mazohisma ekonomiskās problēmas kontekstā par primāro mazohismu. Problemātiku risinot, nevis balstoties biologiijas hipotēzē, pievēršoties dzịlu psihologijas jautājumam par mazohisma primaritāti, mazohisma ekonomisko problēmu. Freida hipotēze ir, ka cilvēkā ir primārais mazohisms. Šo apgalvojumu var interpretēt, ka tas, ka cilvēkā jau sākotnēji ir nāves dziņa, vēl nenozīmē, ka cilvēks primāri ir mazohistisks. Primāro mazohismu var interpretēt, ka Es ir pirmais Tas objekts, pie kā nokḷūst dziṇu enerğija, tad primāri nāves dziņa tiek uzṇemta Es veidojumā, bet tas nenozīmē, ka tā tiek vērsta pret Es kā pašu vai Es kā objektu. Ir iespējams nošķīrums, kad nāves dziņa ir Es veidojumā - primārais mazohisms un kad tā vēršas pret paša Es vai pret Es kā pret objektu - sekundārais mazohisms. Fromms neproblematizē jautājumu par primāro un sekundāro mazohismu. Ja mazohisma ekonomisko problēmu saista ar destruktivitāti, tad graušana, pirmkārt, tiek vērsta pret ārpasaules objektiem, otrkārt, pret pašu, proti, vēl vairāk padarot pašu bezspēcīgu, atkarīgu, - iznīcinot patīgo. Tādējādi destruktivitāte sasaucas ar mazohismu, iekavās liekot seksuālo apmierinājumu. Destruktivitātes mērḳis ir individuālā (Es), individualitātes nāve. Taču iekšpus vērsta destrukcija nav primāra. Tā ir būtiskākā atškirīiba no Freida. Saskaṇā ar Fromma uzskatu, destruktivitāte primāri tiecas iznīcināt ārpasaules objektus, taču problemātisks saglabājas aspekts, kāpēc destruktivitātei galu galā jāvēršas pret pašu un nevis tā nemitīgi pārvirzās no viena agresijas mērķ̣a pie otra, līdz to iespējams atslogot.

Destruktivitātes atšķirība no primārā mazohisma ir tā, ka destrukcijas pirmais mērķis ir nevis pats, bet gan ārējs objekts, turklāt, destruktivitāte aktualizējas nevis patstāvīgi vai līdzās dzīves dziṇu mērḳiem, bet gan, ja 
tiek kavēti dzīves dziṇas mērḳi, pieaug destruktivitāte. Ārējs atraidījums nepieciešami neveicina to, ka destrukcija vērsīsies atpakal̦ uz pašu, bet gan vispirms to, ko nevar iegūt vai no kā gūt apmierinājumu, mēgina iznīcināt. Tikai tad, ja tas neizdodas dažādu apstākḷu dẹl, destrukcija vēršas atpakal, uz pašu. Fromma izstrādņu perspektīva, tomēr, n,emot vērā dzīves un nāves dziņu dualitāti, ir sadisma primaritāte, turklāt destrukcija ir nevis patstāvīga dziṇas virzība, bet tā rodas dzīves dziṇu vietā kā tranformācija.

Dzìves dziņu mērķis ir ne tikai uzturēt dzīvības procesus, bet arī darīt dzīvi tīkamu, aktualizējot iespēju laimīgai būšanai. Tā kā kultūras mērḳis nav darīt cilvēku laimīgu, tad cilvēka individuālie mērk,i var nesaskanēt ar kultūras centieniem, kas var radīt stāvokli „neizdzīvotai dzīvei” vai bezspēcību un bailes būt brīvam, pret ko indivīds cīnās ar destruktīiām vai sadomazohistiskām tendencēm. Agresijas savaldīšana var norādīt arī uz pašpārvaldīšanu un nevis uz nepieciešamību radīt pašdestrukciju, proti, destrukcijas savaldīšanu var skatīt kā patības tehniku. Tādējādi ar destrukcijas savaldīšanu tiek pārvarēta arī paša mazvērtības izjūta - bezspēcība, proti, pašsavaldīšanās, pašpārvaldī̌̌ana ir savas bezspēcības, bezvarības pārvarēšana. Tā būtu nevis bēgšana no brīvības, bet gan iespēja pašrealizēties, būt pašam.

\section{Vēres}

I Šuvajevs I. Dzìlu psiholoğija. Rīga: Zvaigzne ABC, 2002, 191. lpp.

2 Freids Z. İgnums kultūrā. / Tulkojis I. Šuvajevs. Rīga: Zvaigzne ABC, 2000, 39. lpp.

3 I. Šuvajevs tulkojis 'Lust' kā patiku. Kopumā tiek ievērota 'Lust' atveide latviešu valodā kā ,tîksme”.

4 Freids Z. İgnums kultūrā, 42. lpp.

5 Ibid., 79. lpp.

6 Fromm E. Escape from Freedom. New York: Holt Paperback, Henry Holt and Company, 1969 , p. 138.

7 Fromm E. Escape from Freedom, p. 139.

8 Fromm E. Escape from Freedom, p. 140.

9 Ibid., p. I63.

Io Fromm E. Escape from Freedom, p. I5 I.

II Ibid.

I2 Fromm E. Escape from Freedom, p. 152.

13 Ibid., p. 199.

14 Ibid., p. 202. 
Is Freida hipotēze ir šāda: jebkura organisma modifikācija, kas tam tikusi uzspiesta organisma dzīves gaitā, ir konservatīvo dziṇu pieņemta un uzkrāta tālākai atkārtošanai. Tāpēc šās dziņas ir maldinošas. It kā tās tiektos pēc pārmaiņām un progresa, kamēr patiesībā tās tikai meklē veidus, kā sasniegt seno mērķi pa dažādiem cel̦iem. Gala mērķis visiem organisma centieniem ir nāve. Freids raksta: „Tas būtu pretrunā ar dziṇu konservatīvo iedabu, ja dzīves mērkịis būtu lietu stāvoklis, kas nekad vēl nav bijis sasniegts. Tieši pretēji, tam jābūt agrākam lietu stāvoklim, iekšejam stāvoklim, no kura dzīvā vienība vienā vai citā laikā novirzìjās un uz kuru tā cenšas atgriezties pa apkārtceḷiem, kurp kopumā tās attīstỉba ved. Ja mēs to pien,emsim kā patiesību, kas nepazīst izñēmumus, ka viss dzìvais mirst iekšéja cēloṇa dēl - kḷūst atkal neorganisks -, tad mums vajadzētu būt piespiestiem teikt, ka „visa dzīvā mērḳis ir nāve" un, skatoties atpakal, ka „neorganiskās lietas eksistēja pirms dzīvajām". Sk.: Freud S. Beyond the Pleasure Principle. Freud S. The Essentials of Psycho-analysis. / Transl. by Strachey J., ed. by Freud A. London: Vintage Books, 2005, p. 246.

16 Fromm E. Escape from Freedom, p. I82.

I7 Freud S. Beyond the Pleasure Principle, p. 239.; citēts pēc: Šuvajevs I. Freida Lieta. Rīga: Intelekts, 2003, 192. lpp.

18 Freids Z. İnums kultūrā, 84. lpp.

I9 Freud S. The Ego and The Id. Freud S. The Essentials of Psycho-analysis. / Transl. by Strachey J., ed. by Freud A. London: Vintage Books, 2005, pp. 465.

20 Freids Z. Mazohisma ekonomiskā problēma. Freids Z. „Bērnu sit”. / Tulkojis I. Šuvajevs. Rīga: Zvaigzne ABC, 1998, 96. lpp. Freids atsaucas uz varasgribas (Wille zur Macht) konceptu, kas jau sastopams Nī̌̌es darbos un ko izstrādājis A. Ādlers darbā „Par neirotisko raksturu" (Über den nervösen Charakter, 1912).

2 I Fromm E. Escape from Freedom, p. I82.

22 Freud S. Instincts and their Vicissitudes. Freud S. The Essentials of Psycho-analysis, Pp. 2 Iо. 


\title{
Anne Sauka
}

\section{'Būt' un 'piederēt' miesiskās patības ētikas kontekstā}

\author{
„Smadzeñojošais cilvēks ir atsvešināts [..] kad viņš \\ domä, ka vinns aptver realitäti, tad patiesïba to aptver \\ vienīgi vina smadzeniskā patība,bet viņšpats, veselais \\ cilvēks, vinga acis, rokas, sirds, vëders neaptver neko - faktiski \\ viņš̀ nepiedalās pārdzìvojumā, ko pats uzskata par savu." \\ (Ē. Fromms. Psiboanalīze un dzenbudisms)
}

IEVADS

Viens no centrālajiem jautājumiem dižā humānista Ēriha Fromma filosofijā ir jautājums par labbūtīgo dzīvi. Darbā „Piederēt vai būt?", ${ }^{1}$ kà arī tā turpinājumā „Māksla būt”2 autors šim jautājumam pievēršas pragmatiskā aspektā. Proti, viņš izvērtē sabiedrības sociopsihologisko noskaņojumu un iezīmē divas kontrastējošas ētiski psiholog̣ijas dzìves pamatorientācijas (tebūšanas modus), kas, viṇaprāt, caurstrāvo cilvēka dzīvesvedumu. „Būt”" (to be) tiek pretstatīts "piederēet " (to have), un attiecīgi „būt" dzìvošanas mods tiek atspogulots kā produktīiās dzīves dimensijas pamatpazīme, savukārt "piederēt" - kā neproduktīvās dzīves dimensijas pamatpazīme. Turklāt šì dzīves binārā dispozīijia, viņaprāt, sastopama gan individuāāâ, gan arī plašākā sociālā kontekstā, kā visas sabiedrības kopējo dzīives intenci raksturojoša. 
Lai arī šai Ē. Fromma veiktajai dzīves modu analīzei ir pragmatiski ētiska ievirze mācīt produktīvo jeb labbūtīgo, biofilo ${ }^{4}$ dzīvošanu iepretim neproduktīvajai, tukšajai, nekrofilajai ${ }^{5}$ dzīvošanai, (kas piel̦auj arī interpretāciju, ka $\bar{E}$. Fromma teorija lielā mērā sabalsojas ar ideolog̣iskas dzīvesmākslas tradīciju), tematikas apceres mērḳis ir arī sociālpsiholog̣isks - analizēt pastāvošo sociālpsihologisko situāciju un, balstoties uz šīs analīzes datiem, nošķirt un definēt sabiedrībā pastāvošās parādības un tendences.

Šì apcerējuma mērḳis ir divējāds. Pirmajā daḷā uzmanība ir vērsta uz Ē. Fromma humānisma iekšējo pretrunīgumu, kas izriet no iespējamās viņa koncepcijas kritikas, kas balstīta paša Fromma sniegto „būt” un „piederēt” vēlamo attiecỉbu vadlīniju un pasīvā nihilisma koncepta analīzē. Proti, tiek parādīts, kā „piederēt” un „būt” nošķīuma radikāla izpratne, kā arī „piederēt” pilnīga degradācija, pasludinot tā pilnīgu „neproduktivitāti”, var novest pie pasīvā nihilisma stāvokḷa (indivīda vai sabiedrības līmenī), kas ir pretrunā ar Ē. Fromma izvirzìto ētikas mērḳi - panākt cilvēka potencialitāšu pilnīgu piepildījumu. ${ }^{6}$ Citstarp apcerējuma pirmās daḷas uzdevumā ietilpst arī izvērtēt Ė. Fromma ètiskā piedāvājuma iespējamību un sasniedzamību.

Savukārt otrajā apcerējuma daḷā tiek izteikts Ē. Fromma koncepcijas rehabilitācijas piedāvājums, ņemot vērā 'citādu' viṇa rakstītā lasījumu, kas izriet no iespējamības $\bar{E}$. Fromma iezīmētās dzìves pamatorientācijas saistīt un balstīt miesas fenomenolog̣ijas piedāvāto miesiskās patības „būt” un "piederēt” aspektu nošķīrumā, kas parādās kontekstā ar miesas un ķermeņa jēedzienu nošķīrumu. ${ }^{7}$ Tātad šajā apcerējuma daḷā 'būt' un „piederēte modiem tiek pieškirts ontologisks pamats, kas, iespējams, varētu atcelt tā sociālpsihologiski radikālu interpretāciju un Ē. Fromma nošķīruma pretrunīgumu, kā arī l̦auj izdarīt secinājumus par to, kā Fromma aplūkotās dzìves pamatorientācijas (ja tiek atcelta „būt” un „piederēt” radikāla nošķirtība) iekḷaujas visdažādāko dzīves jomu īstenojumā, atklājot miesbūšanu ${ }^{8}$ kā „būt” moda realizāciju.

Apcerējuma mērķis ir paplašināt un padzilıināt darbos „Piederēt vai būt?” un „Māksla būt” izvērstās tematikas filosofisko un ētisko dimensiju, izdarot pieñēmumu, ka Ė. Fromma koncepcijas miesas fenomenolog̣ijas konceptuālā sasaiste ne tikai paplašina „būt” un „piederēt” modu teorētisko un ētisko pielietojamību, bet arī risina apcerējuma pirmajā daḷā aplūkoto iekšèjā pretrunīguma un Fromma postulētās pasìvi nihilistiskās pozīcijas problēmu. 


\section{ĒRIHS FROMMS VAI PASİVAIS NIHILISTS?}

Darbā „Piederēt vai būt?” un tam sekojošajā „Māksla būt” Ērihs Fromms izvērš mūsdienu sabiedrības kritiku un piedāvā divus sabiedrības sociopsiholoǵisko orientāciju raksturojošus dzīves modus - „būt” un „piederēt", caur kuru prizmu skaidrotas cilvēku savstarpèjās attiecības pasaulē un indivīda iekšējā dzīves uzstādījuma virzība. Šì Ē. Fromma koncepcija saistīta ar vairākām filosofijā nozīmīgām jomām - individuālo un sociālpsihologiiju, ētiku un sociālo filosofiju (konkrētāk: patērētājsabiedrības kritiku), kuru ietvarā jau pirms un arī pēc Fromma izvirzìtas līdzīgas koncepcijas. Jāatzìmē, ka Fromma ētiskā pozīcija būtiski saistīta arī ar dzenbudisma ētisko dimensiju, kas plašāk izvērsta viņa darbā „Psihoanalīze un dzenbudisms” un parādās arī darba „Māksla būt” ietvaros. Tieši saikne ar dzenbudisma mācību visupirms ḷauj nojaust iespējamo E. Fromma koncepcijas pasīvā nihilisma raksturu.

Pirms risināt pasīvā nihilisma problēmu Ē. Fromma darbos, vispirms īsi jāapkopo sabiedrības kritika, kas izteikta ar jēdzienu pāra „būt” un „piederēt” palīdzību:

'Piederēt' moda pamatorientācija aplūkota pārsvarā darbā „Piederēt vai būt?”, un Fromms to lielākoties atklāj caur mūsdienu sabiedrības kritikas prizmu. Šis dzīves mods iezīmējas kā patērētājsabiedrībā dominējošā dzīves ievirze, cilvēka vispārēja tieksme pēc 'īpašuma', kas izpaužas ne tikai kā vēlme iegūt materiālus labumus un vērtēt savas dzīves kvalitāti attiecībā pret iegūtajām lietām, ko var nopirkt par naudu (kā mašīna, māja, apgeērbs u. tml.), bet arī vispārīga tieksme izvērtēt visu caur 'īpašuma iegūšanas' kvantitatīvo prizmu. Mūsdienās iegūta tiek 'izglīīiba,' 'cilvēku uzmanība', kā 'iegūtas' tiek vērtētas arī atmiņas, uzkrātās zināšanas un pieredze. Tāad 'piederēt' mods attiecas uz visām trim pamatattiecību pastāvēšanas dimensijām:

- attiecībām ar sevi (identitātes izpratne 'piederēt' modā - es kā iegūto zināšanu, pieredzes, atmiņu un īpašỉbu summa u. tml.),

- attiecībām ar citiem (kvantitatīva draudzības izpratne („,man facebook ir 403 draugi, tātad esmu populārs”), mīlestîba kā ìpašumtiesības, attiecības kā varaskāres un sāncensīguma izpausmes iespēja u.tml.) un

- attiecībām ar pasauli (laime kā vēlamo īpašumu 'savākšana', dzīve kā 'iepirkšanās virkne’ u.tml.); 
'Būt' dzīves pamatorientāciju Ē. Fromms pozicionē kā pilnīgu pretstatu aprakstītajai 'piederēt' moda pamatorientācijai. Prasība 'būt' paredz sevis izkopšanu, dzīvesmākslu, attieksmi pret sevi kā 'mērkịi, nevis līdzekli', patiesas mīlestības un draudzības jūtas, kā arī varaskāres, naudaskāres, lepnības un citu destruktīvu jūtu atmešanu.

Galvenās problēmas, ar ko sastopamies šo dzīves modu noškīinumā, ir:

I) radikalitātes problēma: 'būt' moda principiālais ētiskais pārākums pār modu 'piederēt';

2) ideālisma problēma: 'būt' moda ētiskā mērķa 'nesasniedzamība', cilvēka principiālā nespēja atrasties tikai 'būt' moda dimensijā;

3) nihilisma problēma: 'būt' moda iekšèjais pretrunīgums, proti, 'būt' moda vēlamā un potenciālā ètiskā mērķa pretruna.

Visas šīs problēmas, protams, ir savstarpēji saistītas. I. problēma ietver arī 2. problēmu un priekšnosaka 3. problēmas rašanās iespējamību. Tālākajā izklāstā iezīmēta šo problēmu filosofiskā dimensija, uzrādot pasīvā nihilisma ètisko pozīciju Ē. Fromma darbos.

\section{I.-2. RADIKALITĀTES UN IDEĀLISMA PROBLĒMA}

Radikalitātes problēmu varētu nosaukt arī par dihotomijas problēmu. Iepriekš iezīmējot 'piederēt' moda struktūru, atzīmēju, ka šis mods iedarbojas uz visām trim cilvēka attiecību dimensijām - attiecībām ar sevi, attiecībām ar pasauli un attiecībām ar citu. Šo trejādību nepieminu nejauši - tā norāda uz vēl kādu iespējamu Ē. Fromma koncepcijas risinājumu, kas diemžēl darbā „Piederēt vai būt?” neparādās. Proti, šĩ trijkāršā attiecība parādās vairāku ebreju filosofiskās tradīcijas pārstāvju darbos - piemēram, Emanuēla Levina, Martina Būbera un Franca Rozencveiga filosofijā. Arī šajās filosofiskajās domās tiek kritizēta Rietumu sabiedrības ētiskā pamatorientācija, taču šai kritikai parādās metafiziskā dimensija. noliedz 'es - tas' attiecību bināro stāvokli, ieviešot trešo 'spēlētāju'. M. Būberam šajā trijstūrī parādās 'es' (Ich), 'tu' (Du) un 'tas' (Das) ${ }^{9}$ vai 'es,' 'pasaule' un 'dievs, ${ }^{10}$ līdzīga shēma dažādās interpretācijās parādās arī F. Rozencveiga ${ }^{11}$ un E. Levina filosofijā. 'es', 'pasaule', 'dievs'. „Problēma” (ētiskā un sabiedriskā nozīmē) rodas tad, kad kāds no šiem trim elementiem tiek izspiests. Pēc šo filosofu domām, Rietumu filosofija, un tātad arī sabiedrība, no šīs trijotnes ir 'izstūmusi' cilvēku uzrunājošo elementu, panākot mehānisku pasaules ainu, kurā cilvēks 
savā ziņā ir atstāts 'viens', tas vairs nav vienībā ar pasauli, jo uztver to tikai kā izmantojamu objektu. Ja Ē. Fromma filosofiju saprastu caur šo shēmu, tad atklātos, ka 'piederēt' dominance ir iespējama tieši tāpēc, ka izspiesta ir 'cita' jeb 'tu' dimensija, un tādējādi visos trijos attiecību līmeņos veidojas tīras 'pieprasošā subjekta - apgūstamās pasaules' attiecības. ${ }^{12} \mathrm{Kā}$ vēlamais stāvoklis tad parādītos 'būt' un 'piederēt' modu atrašanās līdzsvarā, kas iespējams, nereducējot 'cita' klātbūtnes dimensiju. ${ }^{13}$ Tātad 'būt' un 'piederēt' pastāvētu nesaraujamā un nepieciešamā saistībā.

Savukārt bez šīs trejādās metafiziskās struktūras 'būt' un 'piederēt' parādās kā radikāli nošķirti elementi (subjekts - objekts, es - pasaule), sevišķi n,emot vērā, ka ētiskā vērtība tiek piešķirta tikai 'būt' dzīves modam, jo kḷūust neizskaidrojama 'būt' potenciālā vērstība, t.i., 'būt' nevar atrasties orientācijā 'uz pasauli' - jo tā ir 'piederēt' moda orientācija, savukārt ja 'būt' iedomājam kā vērstu 'uz sevi' (subjektu), tad Ė. Fromma koncepcija kḷūst līdzīga transcendentālajam ideālismam ${ }^{14}$ un nonāk līdz Kanta uzstādījumam 'cilvēks kā mērkịis, nevis līdzeklis' un visām no šì principa izrietošajām problēmām.

Pati būtiskākā no tām šeit ir šī uzstādītā mērķa nesasniedzamība - proti, netiek ņemts vērā, ka cilvēks nepieciešami atrodas relācijā ar pasauli, tāpēc, ja iedomājamies 'būt' kā mērķi pašu sevī, tad subjekts 'būt' modā, vēršoties pats sevī, novēršas no pasaules un tātad tiek veikts pasaules noliegums. Tādējādi ideālisma problēma paver ceḷu nihilisma problēmai.

\section{NIHILISMA PROBLĒMA}

Esošajā aprakstā 'piederēt' dominance pielīdzināma 'cita' nolieguma stāvoklim. Tiktāl Ė. Fromma viedoklim var piekrist. Iepriekš jau tika minēts, ka 'es', 'tu', 'pasaule' trijādi var saprast arī kā 'es', 'tu' un 'dievs'. Kā atklājas arī Nīčes filosofijas kontekstā, 'dieva nogalināšana' noved pie reaktīvā nihilisma jeb Dieva meklēšanas zemes virsū. Nīčes shēmā pēc reaktīvā nihilisma seko pasivvais, 'izdziestošais’ nihilisms un šķiet, ka Ė. Fromma vīzija to apstiprina. Proti, Fromma piedāvātais reaktīvā nihilisma pārvarējums nepārvar nihilismu, bet tikai tā reaktivitāti.

Jāizdara atkāpe, norādot, ka šāda interpretācija iespējama tāpēc, ka 'būt' mods Fromma koncepcijā parādās kā pretrunīgs. Autors, protams, tā jēdzienā nav vēlējies ietvert dzīves nolieguma ideju, gluži otrādi - tā mērkisis ir dzìves apstiprinājums, taču tā kā uzstādījums 'būt' parādās kā mērkịis pats 
sevī, iztrūkst būtiskās ‘vērstības' („uz ko būt?” „kam būt?”). Tādējādi ‘būt' mods attēlojas kā tāds, kura uzdevums ir iznīcināt vai izgaisināt cilvēka attiecíbas ar pasauli, tā novēršot 'piederēt' moda dominanci, bet arī izraisot paša subjekta 'izgaišanu’.

Tātad Fromma iztēlotā pasaules aina īstenojas kā 'pasaules noliegums', kas atgriezeniski paredz arī 'es' izšks̄išanu vai izgaišanu radītajā 'nekurienē', kas Nīčes filosofijas ietvaros pielīdzināms pasīvā nihilisma stāvoklim. Dievs jau ir miris, bet kā risinājums tiek piedāvāta nevis cilvēka rekonstitūcija, bet pasaules noliegums un tātad arī subjekta pašnoliegums. ${ }^{15}$

Šo pretrunu der aplūkot tuvāk. Darba 'Māksla būt' i. daḷā Ē. Fromms piemin prasību pēc 'totālas atbrīvošanas ${ }^{16} \mathrm{kā}$ 'būt' moda īstenojuma. Totālā atbrīvošana (liberācija) ir iekšêjā atbrīvošanās, proti, tā visupirms paredz atbrīvošanos no iekšējiem brīvības ierobežojumiem, ${ }^{17}$ tādiem kā varaskāre, mantkārība un citas par destruktīvām uzskatītām īpašībām, kas balstītas 'piederēt' dzīves uztverē. Jāsaka, ka šāds uzstādījums visticamāk noved pie secinājuma, ka pilnīga 'būt' realizācija paredzētu arī principiālu atteikšanos no 'gribas' kopumā, un tādā veidā arī no individualitātes aktualizācijas un īstenošanas, ko Nīče postulē kā aktìvo nihilismu, jeb 'vērtību pārvērtěšanu’ un 'jā’ teikšanu dzīvei.

Te vēlreiz jāsastopas ar radikalitātes un ideālisma problēmām Fromma koncepcijā, t.i., 'būt' - 'piederēt' modi tiek aplūkoti kā nošķirti elementi un ētiskais mērkíis ir panākt pēc iespējas lielāku 'būt' dominanci, aizmirstot par cilvēka vērstību uz pasauli, kas paredz, ka cilvēks nevar pastāvēt, neatrodoties starp abiem šiem dzīves modiem.

Visu vēl vairāk sarežg̀ì arī apstāklis, ka Fromma atbrīvošanos no 'piederēt' iezīmē arī atbrīvošanās no gribas. Tiek iezīmēti gribas negatīvie aspekti (varaskāre, uzkundzēšanās, kāre pēc naudas u.tml.), taču 'būt' dzīves mods tomēr parādās kā īstenojuma mods. Lai cilvēks spētu īstenoties, tam nepieciešami jāpiemīt gribai, tātad ir saprātīgi pien,emt, ka 'būt' modu raksturo gribas jēdziens. Tomēr, ja pieñem, ka 'būt' realizējas tikai būšanas ietvarā, nevirzoties uz 'kaut ko' (jo 'kaut kas' uzreiz paredz zināmu 'piederēšanas' elementu), tad 'griba būt' kḷūst paš-atcel̦oša, proti, tā izšḳīst vispārējā mērkīī, kura vispārīgums norāda uz tā nebūtīgumu. Griba kḷūst par gribu 'uz neko' vai principiālu negribēěsanu, kas savukārt ir pasīvā nihilisma priekšnoteikums.

Lai to ilustrētu, var sniegt piemēru par 'mīlestību', - É . Fromma koncepcijā mīlestība no 'piederēšanas' moda („Es viṇu gribu!”) tiktu pārvērsta 
'būt' moda îstenojumā („Mīlu pašas mīlestības pēc!”). Sākotnēji tā šķiet produktīva pārmaiṇa, taču, pārdomājot konsekvences, kas izriet no mīlestības, kurai nav mērķa ārpus sevis, atklājas, ka šādai mīlestībai visticamāk nav svarīgs subjekts, pret ko tā ir vērsta. Proti, ja mīlestỉba pati sev kḷūst par mērkịi, tā pārvēršas par 'mērkịi sevī', tāpēc tai ir pieejama vairs tikai es-realizācija vai radikālā gadījumā (ja 'es' tiek iznīcināts) - pašrealizācija. 'Mīlestîba', šãdi izprasta, principā atceḷ pati sevi. Tā var būt vêrsta pret jebkuru, pilnīgi neizšçirīgi no tā raksturojošām individualizējošām iezīmēm, un tādējādi tā nav vērsta ne pret ko, vai drīzāk - ir vērsta uz 'neko'.

Šāda koncepcija var būt iespējama, un tā ir vairāku ezoterisko un reliǵisko tradīiju ētiskais mērķis. E. Fr. Fromma nostāju var saprast, ja atceras, ka viṇa koncepcija lielā mērā saistìta arī ar dzenbudisma uzstādỉjumiem. Tādējādi vēlreiz atklājas pretruna - šāda koncepcija neapliecina 'jā’ teikšanu dzìvei un tāpēc dara neiespējamu tādu cilvēka paštapšanu, kas l̦auj realizēt cilvēciskās potencialitātes un realizēt sevi 'es-tu', 'es-es' un 'es-pasaule' attiecībās. Taču tieši cilvēka potencialitātes îstenojums ir Ē. Fromma pasludinātais mērḳis.

\section{ĒRIHA FROMMA LASĪJUMS 'MIESISKĀS PATĪBAS' KONTEKSTĀ}

Iepriekš teiktā kontekstā jāatceras, ka Ē. Fromma mērḳis patiesībā ir pretējs pasìvā nihilisma uzstādījumam - viņ̧̌s savā ziņā paredz cilvēka paštapšanu caur dzīvesmākslu, taču ontolog̣iskā ziṇā pašreizējā sistēma šķiet nestabila un viegli noved pie iepriekš aprakstītajām problemātiskajām konsekvencēm. Tātad ir nepieciešams 'cits' lasijjums, kas pieḷautu citādu 'būt' un 'piederēt' modu interpretāciju.

Šķiet, lielākā problēma, kas parādās Ē. Fromma koncepcijā un noved pie viña êtiskam mērķim pretējām konsekvencēm, ir 'būt' un 'piederēt' modu nošķirtība, kas liek vienu no dzìves modiem pasludināt par 'pareizo' dzīves orientāciju, nemeklējot līdzsvaru starp abām dzīves vērstībām. Manuprāt, šo problēmu izraisa ontolog̣iska pamata trūkums abu sociopsihologisko elementu shēmā - proti, Fromma ètiskā pozīcija šşiet skaidra līdz brīdim, kad pievēeršas tās ontolog̣iskai analīzei. Tāpēc šajā apakšnodalāa piedāvāts aplūkot 'būt' un 'piederēt' dzìves modus caur miesiskās patîbas fenomenologijias un ètikas prizmu, norādot uz šo elementu savstarpējo saistỉbu, ciktāl tā atklājas miesas un ķermeṇa nošḳīruma un ontologiiskās vienības kontekstā. 
Darbā „Miesbūšana kā uzdevums” G. Bēme norāda uz miesas un ķermeña nošķīrumu pamatvārdu „būt” un „piederēt” kontekstā. ${ }^{18}$ Proti, miesa tiek raksturota kā „esošais” - var runāt par miesbūšanu vai miesisko būšanu un miesisko patību, jo miesa būtiski ir tas, kas esi tu pats.

Jau sākotnēji ir skaidrs, ka lielā mērā šĩ miesas un konkrētāk - miesbūšanas izpratne saskan,ojas ar E. Fromma aprakstīto „būt” dzīves modu. K,ermenis savukārt tiek raksturots kā „tas, kas tev pieder”, tātad noteikti ir „pieder” moda sastāvdaļa, un iespējams arī „piederēt” moda vispārīgā potenciāla ierosinātājs, ja pieņem, ka tieši cilvēka attiecības ar sevi (un tātad arī savu ķermeni) ir tās, kas veido psihofiziologisko pamatu sociopsihologiskajam dzīvošanas orientācijām, pie kurām ir pieskaitāms „piederēt” dzīves mods. Tomēr būtiskākais aspekts, kas 'miesas' un 'ķermeņa' nošķīruma kontekstā atklājas, ir 'būt' un 'piederēt' nešksiramība. Proti, to nepieciešama līdzāspastāvēšana miesā. Lai to saprastu, īsi jāiezīmē miesas/ķermen̦a nošķ̄īums un es-apziņas konstituēšanās.

Proti, raksturojot miesas jēdzienu kā 'to, kas esi tu pats' ar 'miesas' jēdzienu miesas fenomenologijas kontekstā, B. Valdenfelza un G. Bēmes darbos tiek tverts cilvēks tā kopumā, nereducējot indivīda patību līdz 'prāta' vai 'gara' konceptiem. Miesiskā patība tātad ietver visu cilvēku kopumā, ieskaitot bezapzinātos un apzinātos procesus, kā arī miesisko jutoṇu, kas ietver visatšķirīgās sajūtas, sākot no 'taureņiem vēderā', savādām priekšnojautām, dusmām un greizsirdību un beidzot ar sāpēm, cilvēka ētisko dispozīciju kopumā un pat 'racionāliem' apsvērumiem. Tātad ar jēdziena 'miesa' palīdzību cilvēks tiek tverts tā kopumā kā vienība, nenošķirot 'prāta' un 'ķermeņa' jēedzienus (un līdz ar to izvairoties no analìtiskajai filosofijai raksturīgajām problēmām, meklējot mākslīgu saikni starp tiem). Šai līdzīga miesas koncepcija pirmoreiz parādās Nīčes filosofijā, kur miesa tiek konceptualizēta kā 'liels prāts'. ${ }^{19}$ Miesa šajā koncepcijā ir primāra es-apziņai, proti, es-apziņa var tikt saprasta kā miesas 'instruments', lai iedarbotos uz pasauli. Konstituējot es-apziņu, miesa it kā 'atsvešinās' pati no sevis, jo, lai arī es-apziña ir miesas daḷa, tomēr tās raksturs, tās spēja konstituēt savu appasauli liek tai apzināties sevi kā miesai primāru, uztverot miesu kā savu instrumentu. Tā parādās 'ķermen,a' jēdziens - es-apziņas konstituēts, bieži arī konstruēts miesas tvērums. 'Ķermenis' tādējādi ir tas, uz ko attiecināms ķermeña vēsturiskums, piederība diskursam. Pateiktā kontekstā, lai būtu 
iespējama tālāka diskusija par 'būt' un 'piederēt' dzīves modiem, būtiski ir trīs miesiskās patības aspekti:

I) Miesas nepieciešamā klātesamība.

Proti, 'miesa' nevar pavisam 'izzust', jo tā ir pamatā cilvēka būšanai un tātad ir nemitīgi klātesoša, pat ja cilvēks neatzīst vai nesaprot tās klātbūtni. Miesiskā patība cilvēku iezīmē ontolog̣iski un esenciāli. Tas atklājas robežsituācijās, kurās cilvēks nepieciešami apzinās savu 'miesiskumu', tādās kā sāpēs, baudā, slimībā, svētlaimē u.c., kā arī mazāk izteiksmīgās situācijās - pēc labas maltītes, iemīloties, ieraugot skaistu ainavu u.c. Neatraidāmais 'miesiskums' vienmēr ir klātesošs, bet ne vienmēr jūtams.

2) 'Kermena' iluzoritāte.

Tā kà es-apziņas konstituētais 'ķermenis' ir sociālās realitātes daḷa, tā 'tēls' savā ziñā ir iluzors, iztēlots ideāls, kas turklāt nevar aptvert visu miesiskās būšanas vienību. (Kas izskaidro 'miesas' nekonceptualizējamu un neobjektivizējamu 'parādī̌̌anos'.) Proti, tas ir diskursīvais 'ķermenis', kas nepieciešams, lai es-apziņa spētu caur tā pastarpinājumu tvert un realizēt savu būšanu pasaulē. Tāad iespējama lielākā vai mazākā mērā izpaudusies 'ķermenizācija', atkarībā no tā, cik lielā mērā es-apziņa objektivizējusi ķermeña tvērumu un cik lielā mērā aptver savu primāro 'miesiskumu'. Ja es-apziņa nepien,em savu miesisko iesaisti pasaulē un postulē savu pārākumu 'pār ķermeni', tā pasauli tver pārsvarā 'piederēt' dzīves modā. Tādējādi diskusija par 'piederēt' un 'būt' ètisko dominanci $\overline{\mathrm{E}}$. Fromma koncepcijas kontekstā ir iespējama, ja pien,em, ka aicinājums 'būt' liek es-apziņai pievērsties savam miesiskumam.

Šajā kontekstā ir būtiski, ka arī Fromms, runājot par „būt” modu, iezīmē divas pretējības, kas katra atsedz citus „būt” aspektus. Viņš izšķir divus pretnostatījumus: „būšana / šķitums” un „būšana / piederēšana”. ${ }^{20} \mathrm{Nav}$ grūti pamanīt, ka „miesas” un „ķermen,a” nošķ̄irums tātad iekḷauj abas šīs pretējības, kas katra norāda vienas parādības atš̌kirīgas dimensijas. Tātad ķermenis iepretim miesai realizējas ne tikai kā piederošais iepretim irošajam, bet arī kā šķietamais iepretim esošajam. Ķermen,a jēdziens reprezentē „inscenēto” dzīves dimensiju vai diskursīvo un simbolisko cilvēka patības dal̦u, savukārt „miesa” tiek asociēta ar miesbūšanu, dabisko (saprastu nevis kā primitīvo, bet kā esošo) un labbūtīgo. Turklāt cilvēks atrodas šo abu ieskāvumā, un īsteno sevi to sakausējumā. ${ }^{21}$ 
Proti, jēdzienu pāris „būšana/šķitums” ir sakritīgs ar jēdzienu pāri „miesiskā patîba/inscenējums”, savukārt jēdzienu pāris „būt/piederēt” ir saattiecināms ar jēdzienu pāri „miesbūšana/ķermenis kā tev piederošais” vai vienkārši „miesa/ķermenis”. Tātad „būšana/šķitums” norāda uz miesiskās patības ǵenealog̣ijas sociālo un vēsturisko aspektu, t.i., šì jēdzienu pāra kontekstā ir iespējams runāt par visu to miesiskās patības problemātikas daḷu, kas attiecas uz patības inscenējumu sociālajā telpā tagadnē un vēsturē, tātad vēsturisko kermeņa inscenējumu un miesas eksistenciāli hermeneitiskajiem aspektiem. Otra pretējība „būt/piederēt” savukārt iezīmē miesiskās patības ǵenealog̣ijas fenomenologisko aspektu - tas l̦auj pievērsties cilvēka būšanai vispār, nepiesaistot cilvēku konkrētai sabiedriskajai situācijai laikā un telpā.

Jāṇem vērā, ka „k,̧ermenis kā piederošais” ir arī inscenētais k,ermenis, ${ }^{22}$ tātad tas ir „škietamais” īpašums, kas nozīmē, ka „piederēšanas” un „škituma” nojēgumi k̦ermeṇa problemātikas kontekstā ir savienojami. Savstarpēji saistīti šie jēdzieni ir arī E. Fromma interpretācijā, īpaši kontekstā ar viņa dzenbudistisko ievirzi, kur materiālās pasaules īpašumi, t.i., „piederošais” ir „گ̌kietamais” jeb neīstā un neproduktīvā dzīves orientācija.

3) Miesas bütiskais ētiskums.

Iepriekšèjā aspekta kontekstā vēl jāatzīmē, ka 'miesa' neapzīmē 'dzīvniecisko' cilvēkā. Proti, miesa nav nošķirama no cilvēciskā un tai nepieciešami piemīt arī ētiskums. Tas nav racionāls vai normatīvs ètiskums, bet cilvēkam sākotnēji piemītoša ētiska dispozīcija, kas padara cilvēku 'cilvēcisku' (bet tāpēc ne obligāti labāku vai sliktāku par citām būtnēm, kas ir gluži citādas diskusijas tēma). Miesas būtiskais ētiskums l̦auj saprast, ka Ē. Fromma aicinājums 'būt' var tikt saprasts kā 'pievēršanās' miesiskumam, tādā veidā it kā 'atgriežoties' pie īstenākas būšanas pasaulē. Tomēr vēlreiz jāuzsver, ka nav iespējama pilnīga ķ,ermeņa destruktēšana un 'atgriešanās pie miesas' šo vārdu radikāāā nozīmē, pirmkārt, tāpēc, ka 'miesas' - 'es-apziņas' - 'k,ermen,a' trijotne ir ontologiska noteiksme un nevis ètisks uzstādījums vai dzīves orientācija, un, otrkārt, tāpēc, ka, teorētiski iztēlojoties es-apziņas instrumenta 'ķermeņa' destruktēšanu, būtu jāpien,em, ka tādējādi tiktu iznīcināta arī es-apziņa, jo ķ,ermeņa konstituēšana ir tā, kas es-apziņai ḷauj sazināties ar pasauli, savukārt es-apziñas iznīkšana nozīmētu, ka arī miesa zaudē savu pastarpinājumu ar pasauli. Tātad miesiskās patības ētikas kontekstā var 
runāt vienīgi par nepieciešamu līdzsvara saglabāšanu 'piederēt' un 'būt' dzīves modu ìstenojumā, nevis viena moda būtisku dominanci pār otru. (T.i., kā negatīvu un mūsdienām raksturīgu gan var iztēloties 'piederēt' moda dominanci sabiedrības tvērumā, taču tā pārvarējums nenozīmē šî moda atcēlumu.)

Šie trīs aspekti, manuprāt, atklāj, kā miesiskās patības ētikas kontekstā iespējams saprast 'būt' un 'piederēt' modu īstenojuma ētiskos aspektus, skatot šos dzīves modus kā neškiramus un nepieciešamus, bet tai pašā laikā arī kā ètiskā vērtējuma iespējamo priekšmetu. Tātad jēdzienu pāris 'būt' un 'piederēt', ja to saprot miesiskās patības ētikas kontekstā, kā atbilstīgu jēdzienu pārim 'miesa' un 'ķermenis', norāda uz dualitāti, kurā dzīvo cilvēks, proti, uz diviem miesisko patību iezīmējošiem dzīves modiem - „būt” orientāciju, kas korelē ar miesas jēdzienu, un „piederēšanas/škituma” ${ }^{23}$ orientāciju, kas korelē ar ķermeņa inscenējuma un ķermeniskā jēdzieniem. Un cilvēks vienmēr būtiski dzīvo šo abu dzīves orientāciju sakausējumā.

No Ē. Fromma koncepcijas izriet, ka sabiedrībā var dominēt tikai viena no šīm dzīves pamatorientācijām, nosakot cilvēces valdošo attieksmi pašai pret sevi un savu dzīves telpu. Ja saprotam to miesiskās patības ētikas kontekstā, atklājas, ka nav iespējama 'būt' moda dominance, jo 'piederēt' ir nepieciešams kā 'būt' ìstenojuma instruments. Tādā ziṇā kā ētiski vēlama ir situācija, kurā 'būt' gan nav dominējošs, taču ir 'primārs', savā ziṇā pat 'piederēt' dzīves moda iekustinātājs. Tātad sasaistē ar miesiskās patības ètiku ir iespējama interpretācija, ka Ē. Fromms patiesībā runā par apstākl̦iem, kuros 'piederēt' vairs nedarbojas kā 'būt' īstenojuma instruments, t.i., 'miesas aizmiršanas' stāvoklis, ko tik tiešām iespējams saskatīt kā mūsdienu sociālpsihologiskā stāvokḷa raksturību.

Proti, Ė. Fromms grāmatā „Piederēt vai būt?” skaidro, ka šodien sabiedrībā prevalējošs ir „piederēšanas” mods, un līdzīgi secinājumi tiek izdarīti arī miesas fenomenologu B. Valdenfelza un G. Bēmes darbos, kur autori norāda, ka miesiskā būšana mūsdienu pasaulē ir 'aizmirsta', sabiedrībai ieslīgstot ķermenizācijā, kas paredz arī nodošanos sevis inscenējumam, zaudējot savas patības viengabalainību, ko var nodrošināt tikai savas miesiskās būšanas apzināšanās. Taču runa ir tikai par 'psiholog̣isku' miesas aizmiršanu, nevis būtiski citādu cilvēka raksturojumu vai pastāvēšanas veidu. Saprotot E. Fromma koncepciju miesiskās patības ètikas ietvarā, 'būt' un 'piederēt' 
nošḳīrums atklāj, ka mūsdienu dzīvespasaulē 'piederēt' dominē pār 'būt', ciktāl ar to saprotama 'piederēt' atteikšanās darboties kā 'miesiskās patības' instrumentam. Tātad vērojama miesas nespēja īstenot savu 'būt' caur 'piederēe' dimensiju. Runa tātad ir par izkroplotōm 'es - pasaule', 'es - cits' un 'es - es' attiecībām. Tāda situācija var izveidoties tikai tāpēc, ka es-apziņai ir iespējams 'aizmirst' vai 'nepamanīt' savu miesisko būšanu. (Šì 'aizmirstība' gan nevar būt pilnīga, tāpat kā nav iespējama arī pilnīga miesiskās būšanas apzināšanās - tātad runa ir par gradācijām.) Caur šo prizmu savukārt iespējams tālāk skaidrot mantiskā, mehāniskā un 'mirušā dominanci pār dabisko, dzīvo un notiekošo, kā tā tiek parādīta Ē. Fromma darbos.

\section{NOSLĒGUMS}

$\check{S}_{1}$ pārsprieduma ietvaros esmu centusies atklāt veidus, kādos „būt” un „piederēet” dzīves pamatorientācijas, kuru raksturojumam Ē. Fromms ir veltījis savu grāmatu „Piederēt vai būt?”, kā arī darbu „Māksla būt”, var tikt konceptuāli saistītas ar miesas un ķermeṇa nojēgumiem, tādējādi stiprinot šì nošķīruma teorētisko pamatojumu un konceptualizējot tādu filosofisko aplūkojuma veidu, kurā šo nošķ̣īumu kontekstā iespējams tvert cilvēka vēsturisko, sociopsihologisko un ontologisko novietojumu pasaulē.

Šis konceptuālais tvērums savukārt var kalpot par tādas ētikas pamatu, kuras aizsākums meklējams filosofiskā dzīvesmākslā, proti, runa ir par ētisku dzīvošanas orientāciju, kas, pirmkārt, balstās personīgās sociopsiholog̣iskās un vēsturiski noteiktās dzīves telpas apzināšanā, un, otrkārt, dara iespējamu, par spīti prevalējošai neproduktīvai dzīves orientācijai, apzināti izvēlēties produktīvu dzīves orientāciju.

Apcerējuma pirmajā daḷā tiek analizētas konceptuālās problēmas un teorētiskās neskaidrības, kas 'būt' un 'piederēt' nošḳīuma ētisko mērḳi aicinājumu 'būt' atklāj kā iespējamu aicinājumu uz pasīvo nihilismu. Pastarpināti šì apcerējuma daļa norāda uz nepieciešamību rast stingrāku teorētisko pamatu 'būt' un 'piederēt' modu nošķ̄irumam, caur kura prizmu izprast šī nošķīruma patieso aicinājumu. Šādu nepieciešamību atklāj pasìvā nihilisma problēma, savukārt šāda pamata iespējamību pamato É. Fromma patiesā ètiskā mērķa nesakritība ar pasīvā nihilisma uzstādījumu. Kā pamatproblēma tika identificēta 'būt' moda vēlamā un iespējamā ètiskā mērķa pretrunīgums. 
Apcerējuma otrā daḷa veltīta miesiskās patības ètikai, izdarot piedāvājumu 'būt' un 'piederēt' sociālpsihologisko nošķīrumu skaidrot un pamatot caur miesiskās patības ētikas prizmu, tā risinot 'būt' moda vēlamā ètiskā mērķa un ētiskā mērķa potencialitātes pretrunīgumu.

Kā dzīvesmākslas mērkịi Ē. Fromms uzsver labbūtīgās dzīves un dzīvošanas jēdzienu, ${ }^{24}$ tādā veidā norādot, ka dzīves mērḳis ir nevis, piemēram, laime vai bauda, bet gan kvalitatīvi, produktīvi nodzīvota dzive, t.i., dzīve, kas nodzīvota „būt” modā. Raksta tapšanas gaitā noskaidrojās, ka dzīve 'būt' modā drīzāk jāsaprot kā dzīve 'būt' un 'piederēt' modu līdzsvarā. Lai šāda dzīve būtu iespējama, cilvēkam visupirms ir jāiespēj pašam sevi, tātad viņam ir jāspēj „būt pašam”, kas nozīmē arī būt brīvam un apzināt to, kas esi tu pats. To, pēc Fromma domām, spēj tikai cilvēks, kurš ir izzinājis un apzinājies savu novietojumu pasaulē. Miesas fenomenologijas uzdevumi ir lìdzīgi25 - tā iekḷauj ne tikai cilvēciskās pasaules ainas izziṇu tās ontologiskajā aspektā, bet arī miesiskās patības ǵenealoǵiju, proti, ķermeņa vēstures un tā sociālpsihologisko aspektu kopuma analīzi.

Tātad „būt/piederēt” konceptuālā sasaiste ar jēdzienu pāri „miesa/ķermenis”, kas atbalsojas arī Ē. Fromma norādītajās pretējībās „būšana/šķitums un būt/piederēt" un, plašākā kontekstā, Fromma koncepcijas sasaiste ar miesiskās patības ētiku, ne tikai piešķir šo dzīves pamatorientāciju izpratnei plašāku filosofisko un ontologisko dimensiju un nepretrunīgumu, bet arī vienkārši paplašina filosofiskās dzīvesmākslas horizontu.

\section{Vēres}

I Fromm E. To Have or to Be?, London: Continuum, 2008, p. 182.

2 Fromm E. The Art of Being. London: Constable, 1993, p. 131.

3 Latviešu valodā nav ekvivalenta ang̣̣u "to have" un vācu ,haben". Domāju, ka būtu pamatoti „piederēt” vietā izmantot vārdu "gūt" vai „gūstams” dzìves pamatorietācijas apzīmēšanai, kas ietvertās jēgas ziņā būtu atbilstošāks tulkojums.

4 Burtiski - bio-philia no sengrieķu valodas „dzīves mīlestïba”, „tieksme pēc dzīves”. Sk.: Fromm E. The Anatomy of Human Destructiveness (1974). London: Penguin Books, p. $485-486$.

5 Turpat, p. 433; Ë. .Fromms raksta: „Necrophilia in the characterological sense can be described as the passionate attraction to all that is dead, decayed, putrid, sickly; it is the passion to transform that which is alive into something unalive; to destroy for the sake of destruction; the exclusive interest in all that is purely mechanical. It is the passion 
to tear apart living structures.” Tātad var arī teikt, ka visa rietumnieciskā zinātne ir savā ziṇā „nekrofila”, jo tā nodarbojas ar dabiskā kontrolēšanu un mehanizēěanu. Sk.: Fromm E. The Anatomy of Human Destructiveness (1974). London: Penguin Books, p. 44I.

6 Fromm E. The Art of Being. London: Constable, 1993, p. I--9.

7 Par miesas un k,ermeña jēdzienu nošķīrumu un abu jēdzienu definējumus plašāk sk.: Waldenfels B. Das leibliche Selbst. Vorlesungen zur Phänomenologie des Leibes. Hg. von Regula Giuliani, Frankfurt/M.: Suhrkamp, 2000, S. 17-41; Böhme G. Ethik leiblicher Existenz: Über unseren moralischen Umgang mit der eigenen Natur. Frankfurt/M.: Suhrkamp, 2008, S. I19-135.

8 Miesbūšaua (Leibsein) tā, kā tā tiek saprasta, šajā referātā visprecīzāk definējuši Gernots Bēme un Bernhards Valdenfelzs. Sk.: Waldenfels B. Das leibliche Selbst. Vorlesungen zur Phänomenologie des Leibes, S. 247-264; Böhme G. Leibsein als Aufgabe: Leibphilosophie in pragmatischer Hinsicht. Kusterdingen: Die Graue Edition, 2003, S. 55-72.

9 Būbers M. Es un tu. Rīga: Zvaigzne ABC, 2010, 160. lpp.

Io Šajā gadījumā dievs nav jāsaprot šaurā religijias kontekstā, bet gan kā metafiziska vai ontologiska vienība, proti, tā loma ir norādīt uz cilvēkbūšanas saškelto stāvokli, - no vienas puses, cilvēks ir aktīvais (uzrunājošais), no otras puses, - pasīvais (uzrunātais).

II Lai arī jāatzīmē, ka Rozencveigs noliedz Būbera priekšstatu par 'es/tu', 'es/pasaule' attiecỉbām, uzsverot, ka pareizāk būtu runāt par 'es/tu', 'viņš/pasaule' modeḷiem, tā priekšmetiskojot cilvēku, kad tas atrodas attiecībās ar pasauli jeb lietām.

I2 Proti, subjekts attiecībās objektivizē un instrumentalizē gan sevi, gan citu, gan pasauli.

I3 Šajā stāvoklī attiecības ar pasauli vienmēr izgaismo arī 'būt' dzīves mods, attiecības ar citu parādās 'attiecību ar pasauli' jeb 'piederēt' dzīves moda kontekstā, bet 'attiecības ar sevi’ jau vienmēr pastāv šo abu modu starp-būšanā.

I4 Par to liecina, piemēram, darba „Māksla būt” ı. nodậa izvirzītā normatīvās ètikas nepieciešamiba. Sk.: Fromm E. The Art of Being, London: Constable, 1993, p. I-9.

Is Tas, ka 'pasaules' noliegums izraisa arī subjekta 'pašnoliegumu', vēl jo vairāk kḷūst skaidrs, n,emot vērā, ka reaktīvā nihilisma jeb 'piederēt' moda dominances stāvoklī subjekts sevi jau ir instrumentalizējis, pārsātinot sevi ar 'pasauli', tādā veidā pašam kḷūstot par 'pasaules lietu'.

16 Fromm E. The Art of Being, p. 6-8.

17 Ibid., p. 8.

I8 Böhme G. Leibsein als Aufgabe: Leibphilosophie in pragmatischer Hinsicht, S. II-40.

I9 „Miesa ir liels prāts, daudzveidība ar matīšanu Vienu, karš un miers, ganāmpulks un gans. Tavas miesas darbarīks ir arī tavs mazais prāts, mans brāli, ko par "garu” tu dēvē, tava lielā prāta mazais darbarīks un rotalllieta.” Sk.: Nīče F. Tā runāja Zaratustra. / Tulkojis Igors Šuvajevs. Rīga: Zvaigzne ABC, 2007, 31. lpp.

20 Sk.: Fromm E. To Have or to Be?, p. 21; 79.

2I Lai arī šis sakausējums var būt vairāk vai mazāk līdzsvarots un produktīvs atkarībā no sociopsiholog̣iskā fona. Šì sakausējuma iekšejo korelatīvo attiecību izpēti var īstenot ar miesas fenomenoloğijas un ķermeña filosofijas apvienotas disciplīnas palīdzību - un šīs 
domāšanas disciplīnas vienotais nosaukums varētu būt „miesiskās patības ǵenealog̣ija”, kas ir arī mana promocijas darba nosaukums.

22 Proti, priekšstats par cilvēku kā būtni, kam piemīt „ķermenis”, kas funkcionāli ir šīs būtnes īpašums (nevis pati šì būtne), veicina ķermeņa inscenējumu, pašam ķermenim pārvēršoties par skatuvi vai arī ķermenim un pasaulei stājoties tēla un skatuves attiecībās. Tādējādi patība nevis ,jau ir” (kā iepriekšdotais) miesiska, bet tā izmanto k,ermeni kā savas pašizpausmes instrumentu.

23 Starp citu, interesanti, ka Gernots Bēme runā par ētisku nepieciešamību mainīt attieksmi pret k,ermeni kā „īpašumu”, uzsverot k,ermeña īpašumtiesībām piemītošo „škietamību”. Sk.: Böhme G. Ethik leiblicher Existenz: Über unseren moralischen Umgang mit der eigenen Natur. Frankfurt/M.: Suhrkamp, 2008, S. 160-162.

24 Sk., piemēram: Fromms E. Psihoanalizze un dzenbudisms. Rīga: Zvaigzne ABC, 2002, II9. lpp.

25 Sk., piemēram: Böhme G. Die Sorge um Sich. Böhme G. Leibsein als Aufgabe: Leibphilosophie in pragmatischer Hinsicht, S. 359-374. 



\section{Ainārs Sauka}

\section{Cilvēka atsvešināti sociālā un dionīsiskā būšana}

IEVADS

19. gadsimtā, kas Rietumu pasaulē ir lielu pārmaiṇu laiks, filosofiskajā domā savu aktualitāti izteiktāki gūst jautājums par cilvēka atsvešināto būšanu pasaulē. Tas ir laiks, kad Rietumu cilvēka stāvokli varētu raksturot ar apzīmējumu „garīgā krīze”. Kaut vai tāpēc vien, ka līdz ı9. gadsimta beigām reliǵija sociālā un visaptverošā nozīmē lielākoties ir atmesta, tās vietā sabiedrībā kopumā pieaugusi dabaszinātṇu nozīme un pasaule tiek skaidrota, balstoties mehānikā. Cilvēki, atmetot reliǵiju, atsvešinās no sevis, no dabas un cits no cita, radot cilvēka tipu, ko domātājs Ērihs Fromms dēvē par homo mechanicus.

Kritizējot Rietumu sabiedrību un kapitālismu, Ē. Fromms raksturojis arī Rietumu cilvēka stāvokli un garīgo krīzi, ar ko sastopas ı. gadsimta beigu un 20. gadsimta sākuma Rietumu sabiedrība. Piemēram, 1960. gada apcerējumā „Psihoanalīze un dzenbudisms”, raksturojot Rietumu cilvēka stāvokli garīgajā krīzē, Ē. Fromms lieto tādus apzīmējumus kā dzīves panīkums, cilvēka automatizācija, atsvešinātība no sevis paša un no dabas.

Domājot par 19. gadsimtu, tā beigām un šì perioda kritiku, var norādīt arī uz kādu citu domātāju, kurš filosofijas vēsturē ir iegājis ar sava laikmeta un sabiedrības kritiku un kura rakstos kaut kādā mērā ir sastopami daži 
domas uzsvari, kas savā zin̄ā ir līdzīgi Fromma darbos izteiktajiem. Proti, dzīves panīkums, cilvēka automatizācija un atsvešinātība ir sastopami arī domātāja Frīdriha Nīčes darbos. Taču bez cilvēka, sabiedrības un laikmeta kritikas Nīčes darbos vēl ir sastopami arī centieni vērtēt un pārvērtēt savu laikmetu un tā vērtības.

Tāpēc šis apcerējums ir mēgeinājums domāt un pārdomāt jautājumu par cilvēka atsvešināto būšanu, būšanu sabiedrībā un būšanu citādam, ieklausoties domātāju Fromma un Nīčes teiktajā.

\section{ATSVEŠINĀTA BŪŠANA - HOMO CONSUMENS, HOMO MECHANICUS}

Runājot par Rietumu cilvēka stāvokli ı9. gadsimta garīgās krīzes apjausmā, var teikt, ka tas ir laikmets, kad kopumā netiek vairs taujāts pēc jēgas, jo līdz ar dabaszinātņu pieaugošo nozīmi uzmanība ir pievērsta tam, kā viss funkcionē. Savukārt tas veicina „vēlmi” atklāt, kā cilvēkam iejaukties šajā funkcionēšanā, pakḷaujot un padarot šo funkcionēšanu derīgu. Turklāt sabiedrība ir pieradusi pie tā dēvētās Darvina evolūcijas idejas, saskaṇā ar ko, piemēram, var teikt, ka nepastāv dzīves mērķtiecīga attīstība, jo dabas process ir mutāciju un selekcijas vésture. ${ }^{1}$

Darbā „Psihoanalīze un dzenbudisms” (1960) Ē. Fromms raksta, ka, lai arī „vairums Rietumos dzìvojošo cilvēku nebūt nejūtas tā, it kā dzīvotu kultūras krīzes periodā (acīmredzot nekad nevienā radikālas krīzes situācijā lielākā dậa cilvēku nav apzinājušies tās pastāvēšanu), tomēr daudzi kritiski novērotāji ir vienisprātis par šās krīzes eksistenci un pazīmēm.”2 Attīstot tālāk šo domu par garīgo krīzi, E. Fromms norāda, ka šī krīze tikusi raksturota kā dzīves panīkums, kā cilvēka automatizācija un atsvešinātība no sevis paša, no saviem līdzcilvēkiem un dabas. Filozofs uzsver, ka Rietumu cilvēka stāvokli turklāt raksturo šizoīda nespēja pārdzīvot emocijas, lai arī viņš izjūt bailes, depresiju un izmisumu. „Vārdos viņš joprojām atzīst, ka viņa mērķis ir laime, individuālisms, iniciatīva, taču patiesībā viņam nav nekāda mērḳa. Pavaicājiet viņam, kāpēc viņš dzīvo, kāds ir visu viņa pūliņu mērkịis, un viņš nezinās, ko atbildēt. Daži varbūt teiks, ka dzīvo gimenei, citi teiks, ka dzīvo, lai „priecātos” vai lai pelnītu naudu, taču patiesībā neviens no viņiem nezina, kāpēc dzīvo, viņiem nav cita mērķa kā vien vēlme bēgt no nedrošibas un vientulības." 
Ė. Fromma sniegtais cilvēka raksturojums savā ziņā sasaucas ar Nīčes Zaratustras vēstījumu par tā dēvēto pédējo cilvēku. Ievada runā Zaratustra vēstī, ka tuvojas laiks, kad cilvēks nedzemdinās vairs nevienu zvaigzni. „Nāk paša nicināmākā cilvēka laiks - tā, kas pats sevi nespēj nicināt," ${ }^{4}$ saka Zaratustra. Taču šķiet, ka vislabāk pédējo cilvēku raksturo tas, ko viņš prot darìt vislabāk, proti, blisināties. „'Kas ir mīlestība? Kas ir radīšana? Kas ir alkas? Kas ir zvaigzne?' - tā jautā pēdējais cilvēks un blisinās." Z Zaratustra

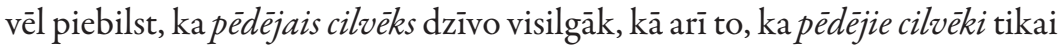
blisinās un saka, ka viņi ir atraduši laimi.

Šàdspēdējā cilvēka tips, kas dzīvo, „lai priecātos”, „lai pelnītu naudu”, par savu „laimi” un „prieku” ir izgudrojis „darba laimi”, un šāda tipa cilvēkus cēlais un pacilājošais („radīšana”, „mīlestība”, „zvaigznes”) tikai garlaiko. Pédējais cilvēeks Nīči nomāc, jo tas ar savu blisināšanos un savu priecin,u dienai, savu naktij kavē pacelties pāri viduvējību trulajai pasaulei. ${ }^{6}$ Šàds cilvēka raksturojums norāda uz tendenci, kas vērojama Ničces dzīves laikā un ne tikai. Runa ir par industriālo, birokrātiski organizēto cilvēku.

Darbā „Cilvēka sirds” (1964) Ē. Fromms, raksturojot cilvēka kā lietas un cilvēka kā dzīvas, dzīvojošas būtnes stāvokli, atzīmē, ka birokrātiski organizētā un centralizētā industriālismā cilvēku tieksmes ir ievirzìtas tā, lai tie patērētu pēc iespējas vairāk un iepriekš paredzamos un peḷnu dodošos virzienos. Viņš norāda, ka šo jaunā tipa cilvēku, ko autors dēvē par organizāciju cilvēku, par cilvēku automātu, radījusi birokrātiski industriālā civilizācija, kas bija valdoša Eiropā un Ziemel̦amerikā. Šo cilvēka tipu Ė. Fromms dēvē par homo consumens. ${ }^{7}$ Taču viņš piebilst, ka homo consumens ir arī homo mechanicus, skaidrojot, ka ar to domāts instrumentu, iekārtu jeb ierīču cilvēks, kam piemīt īpaši izteikta atkarība un ko burtiski pievelk viss mehāniskais, tādējādi novēršoties no visa dzīvā. Runājot par homo mechanicus, Ē. Fromms uzsver, ka šī tipa pārstāvjus, visticamāk, vairāk jūsminās un apburs tādas ierīces, ar kurām, piemēram, ir iespējams nogalināt miljonus no l̦oti liela attāluma dažās minūtēs, taču vismazāk homo mechanicus biedēs vai skumdinās šādas masu iznīcināšanas iespēja kā tāda. ${ }^{8}$

Turpinot attīstīt cilvēka kā lietas un cilvēka kā dzīvas būtnes ideju, E. Fromms konstatē, ka viña dzīves laikā cilvēku pieeja dzīvei ir kḷuvusi mehāniska. Darbā „Cilvēka sirds” viņš raksta, ka par cilvēku galveno mērk, i ir kḷuvusi lietu radī̌sana, kas veicina lietu pielūgsmi, bet šajā lietu pielūgšanā 
cilvēki paši sevi pārvērtuši par patēriņa priekšmetiem. Savukārt kḷūšana par patēriņa (consumens) priekšmetiem veicina to, ka citi pret cilvēkiem sāk izturēties kā pret uzskaitāmām vienībām. ${ }^{9}$ Jautājums nav par to, vai pret cilvēku kā pret lietu izturas labi, saka Fromms, norādot, ka būtiskākais ir jautājums par to, vai cilvēki ir lietas vai arī dzīvas būtnes. ${ }^{10} \overline{\mathrm{E}}$. Fromms uzsver, ka dažādas ierīces cilvēkiem ir kḷuvušas daudz tuvākas par citiem cilvēkiem. Tas savukārt izskaidro, kāpēc cilvēkiem piemīt tendence uztvert citus cilvēkus kā objektus, kas darbojas saskaņā ar masu uzvedības statistiskajiem rādījumiem, un nevis kā dzīvus indivīdus. Pēc Fromma domām, šeit savu lomu nospēlē pieaugošā birokrātisko metožu nozīme.

„Lielajos ražošanas centros, milzịgajās pilsētās un lielvalstīs cilvēkus uzskaita tā it kā viņi būtu lietas; cilvēki un arī viņu uzskaitītāji, administratori ir pārveidoti par lietām, un viṇi visi pakḷaujas lietu likumiem." ${ }^{11}$ Taču É. Fromms uzskata, ka cilvēks nav domāts tam, lai kḷūtu par lietu, jo, kḷūstot par lietu, viņš tiek iznīcināts. Savukārt pirms cilvēks ir kḷuvis par lietu un tādējādi iznīcinājis sevi, viņš ir izmisuma pārņemts cilvēks, kas grib nogalināt dzīvi un dzīvo. Raksturojot šādus industriālos, birokrātiski organizētos cilvēkus, Nīče varētu vien teikt, ka tie ir „uzkrājošie, aprēḳinošie, maš̄inveidīgie". ${ }^{12}$

\section{BAILES NO VIENTULİBAS JEB BŪŠANA SOCLĀLI NOTEIKTĀ FILTRĀ}

Katra sabiedrība, praktizējot sev raksturīgu dzīvošanas, attiecību, izjūtu un uztveres veidu, vienlaikus attīsta kategoriju sistēmu, kas nosaka apziñas formas. „Šì sistēma darbojas kā sociāli nosacìts filtrs." ${ }^{13} \bar{E}$. Fromms skaidro, ka jebkura sabiedrība, lai izdzīvotu, nepieciešami veido tās locekḷ u raksturu tā, lai šie locekḷ, gribētu darìt to, kas vin,iem ir jādara. Proti, sabiedrības locekḷu sociālajai funkcijai ir jākḷūst par kaut ko tādu, ko „viṇi paši izvēlas” īstenot un nevis „ir spiesti” to darīt. Šāds modelis un filtrs, kas nosaka un veido to, ko dēvē par sabiedrības raksturu, ir vajadzīgs, lai šis raksturs nezaudē savu viendabību un stingrību, jo, tiem izzūdot, sabiedrībā dzīvojošie indivīdi varētu pārstāt darīt to, ko no viņiem sagaida, un tādējādi būs apdraudēta sabiedrības izdzīvošana tai raksturīgajā formā. Ē. Fromms atzīmē, ka dažādās sabiedrībās sabiedrības raksturs ir atšķirīgs gan pēc stingrības pakāpes, kādā tas tiek realizēts, gan pēc aizliegumiem, kas tiek ieviesti šā rakstura 
aizsargāšanai, „tomēr visās sabiedrībās pastāv savi tabu, kuru pārkāpšana draud ar izstumšanu" ${ }^{14}$ Būtībā sabiedrības uzdevums ir ne tikai ievadīt tās locekḷu apziṇā sava veida fikcijas, kas vin,iem liek saglabāt sabiedrības kārtību, bet arī attur viņus no realitātes apjaušanas. ${ }^{15}$

Varētu jautāt, kāpēc gan indivīdam izvēlēties palikt un būt saistītam ar sabiedrību, piemēram, pēc tam, kad tas apzinājies savu iemestību un, iespējams, nebūt ne „brīvo” izvēli darboties tajā? Ē. Fromms norāda uz diviem savā ziṇā saistītiem faktoriem. Viens no tiem ir - ciktāl cilvēks ir dzīvnieks, viņš visvairāk baidās no nāves, savukārt ciktāl cilvēks ir cilvēks, vinu visvairāk šausmina un biedē piln̄̄ga vienatne, piln̄̄ga vientulība. ${ }^{16} \mathrm{Bu}-$ tībā „dzīvnieciskās bailes” no nāves sintēzē ar bailēm no vientulības savā ziṇā izskaidro cilvēka izvēli drīzāk darboties un būt sabiedrībā nekā tajā nebūt un būt sociāli mirušam, kas var notikt, indivīdam izvēloties būt pašam, būt atrautam no sabiedrības. Taču šāds iznākums, ka cilvēks labāk izvēlas palikt un būt sabiedrībā, atgādina Fromma rakstīto par to, ka cilvēks, kurš paliek piesaistīts têva pavēlei, var attīstīt ievērojamu iniciatīvas un darbošanās spēju, „tomēr tikai ar nosacījumu, ka līdzās atrodas autoritāte, kura pavēl, uzslavē vai soda". ${ }^{17}$

Cilvēks, kurš labprātīgi izvēlas palikt piesaistìts têva pavēlei, atsauc atmiñā līdzību ar kādu konkrētu dzīvnieku no Nīčes Zaratustras runas „Par trim pārvērtībām”. Šajā runā Zaratustra stāsta par trīs gara pārvērtībām, proti, par to, kā gars kḷūst par kamieli, kamielis par lauvu un visbeidzot kā lauva kḷūst par bērnu. Par kamieli Zaratustra skaidro, ka tas ir sevi pārkrāvis smaguma gars, tas ir tāds gars, kas nes uz savas muguras visu to, kas nav viņa, proti, šis smaguma gars ir apkrāvis sevi līdzīgi kamielim, kam virsū uzkrauts tas, kas nav viña. Bet viņš to visu nes pacietīgi. Taču kādā brīdī šis smaguma gars aizbēg tuksnesī, kur norisinās gara otrā pārvērtība. Tuksnesī gars kḷūst par lauvu, kurš grib sev gūt brīvību un būt kungs pats. Tuksnesī viņš meklē savu pēdējo kungu, kas reizē ir arī pēdējais dievs un pūḳis, uz kura zvīṇām viz tūkstošgadīgas vērtības. Lauva grib cīnīties ar šo pēdējo kungu. Zaratustra arī piebilst, ka lauva ir garam vajadzīgs, lai radītu brīvību jaunai radīšanai. Un tāpēc, ka lauva nevar radīt jaunas vērtības, bet tikai atbrīvot ceḷu uz to radīšanu, garam ir jātop par bērnu, kas ir trešā gara tapšanas pārvērtība. Zaratustra saka, ka bērns ir aizmiršana, jauna sākšana, spēle, no sevis ritošs rats, sākotnēja kustība, svētā "Jā-teikšana". ${ }^{18}$ 
Zināmā mērā šo Zaratustras teikto varētu interpretēt kā norādi uz to, ka cilvēkam ir iespējams būt atškịīgam un rīkoties citādāk nekā sabiedrībā ir pieņemts. Novēršanās no sabiedrības rakstura, ,aiziešana tuksnesī” savā ziṇā nozīmē arī pašizolēšanos no tā, ko sabiedrībā uzskata par derīgu un vajadzīgu. Runa ir par aiziešanu no tā, ko var dēvēt par kamielisko būtību, kas liek cilvēkam lepoties ar to, ka tas spēj nest un veikt to, ko tas pats nav izvēlējies ne nest, ne veikt, ar ko cilvēks tādējādi attaisno savu būšanu atbilstīgam tā dēvētajam sabiedrības filtram. Taču, kā norāda Zaratustra, to ir iespējams pārvarēt un atmest, ,aizejot tuksnesī”, kas nozīmē arī palikšanu vienam.

Uz šāda veida būšanu ārpus sabiedrības filtra, kas nozīmē arī rīkoties atšķirīgi, uzvesties citādāk nekā sabiedrībā ierasts, cilvēku iedrošina ne tikai Zaratustra, kas stāsta par to, ka ir pienācis laiks radīt jaunas vērtības, kuru radīšanai atbrīvot ceḷu ir iespējams, garam topot par kamieli, tam par lauvu un visbeidzot par bērnu, bet arī Ė. Fromms, kurš darbā „Māksla būt” raksta, ka tas, ka citi cilvēki nesaprot atšķirīgu uzvedību, nav nekas būtisks. Jo citu cilvēku, sabiedrības prasība sabiedrības locekḷiem rīkoties un darīt vienīgi to, ko viņi saprot, ir mēginājums izrīkot atsevišķos locekḷus, pavēlēt tiem. Ja sabiedrības acīs atškirīga uzvedība un rīcība nozìmē būt „asociālam” vai rīcība šķiet „iracionāla”, lai tas tā arī ir, uzsver Fromms. „Viņiem galvenokārt nepatīk mūsu brīvība un mūsu drosme būt pašiem. Mēs nevienam neesam parādā nekādu skaidrojumu vai atskaitīšanos tik ilgi, kamēr mūsu rīcība nenodara viņiem pāri vai arī viņus nekādā veidā neaizskar un neierobežo." ${ }^{19}$

\section{CILVĒKA BŪŠANA DIONĪSISKĀ STĀVOKLĪ}

Atsakoties no ilūzijām par tēvišķ dievu kā gādīgu palīgu, cilvēks ir pārvarējis egoistiskās patības robežas, viņš ir atzinis, ka dzīves mērḳis ir pati dzīvošana, raksta É. Fromms, uzsverot, ka tādējādi „cilvēks kḷūst par to, kas viņš potenciāli ir" ${ }^{20}$ Starp citu, viņš arī norāda, ka cilvēkam jebkurā kultūrā ir dotas visas potencialitātes, ar to domājot tādas cilvēka potencialitātes kā „arhaisks cilvēks, plēsīgs zvērs, kanibāls, elku pielūdzējs un arī būtne, kas spēj domāt, mīlēt un būt taisnība". ${ }^{21}$ Ar šo norādi Fromms iezīmē bezapziņas un apziņas nozīmi cilvēka dzìvē. Proti, cilvēciskās potencialitātes paredz, ka bezapziņas saturs nav ne labs, ne l̦auns, ne racionāls, ne iracionāls. Proti, 
tas ir gan viens, gan otrs, jo bezapziņa aptver visu cilvēku, izṇemot to, kas viṇā nav sociāls. Savukārt apziṇa „reprezentē sociālo cilvēku, tos gadījuma rakstura ierobežojumus, kas ir konkrētās vēsturiskās situācijas nosacīti. Bezapziņa reprezentē universālo cilvēku, visu cilvēku, kurš sakņojas kosmosā, tā reprezentē augu vin̄ā, dzīvnieku vin,ā, garu vin̄ā, tā reprezentē gan viṇa pagātni, kas iesniedzas cilvēka eksistences rītausmā, gan viṇa nākotni līdz dienai, kad cilvēks kḷūst pilnīgi cilvēcisks," ${ }^{22}$ skaidro Fromms.

Egoistiskās patības robežu pārvarēšana savā ziṇā sabalsojas ar Ničes rakstīto par dionīsisko neprātu. Proti, runa ir par dionīsisko stāvokli, kurā nonākot notiek cilvēka atbrīvošanās mūzikā, kas tiek piepildīta ar dionīsisku būšanas apliecinājumu - deju, kad cilvēks ir atbrīvojies no „Es” apziñas un, apjēdzot savu mirstīgumu, dziedādams un dejodams ir gatavs "aizlidot gaisu gaisos”. ${ }^{23}$ Kontekstā ar šo aspektu Nīčem ir l,oti būtiski norādīt, ka, nonākdams šajā dionīsiskajā stāvoklī, cilvēks ir gatavs kḷūt par mākslasdarbu dionīsiskajā dzìvesvarā. Kḷūt par mākslasdarbu, nevis būt māksliniekam nozīmē ļauties būšanas mūžīgajam priekam. L,aujoties šim priekam, cilvēks apjauš, ka visam esošajam ir jābūt gatavam uz aiziešanu un bojāeju, tādējādi ielūkojoties individuāleksistences šausmās, apjēdzot cīnas, moku un parādību iznīcību kā nepieciešamu cilvēkbūšanas un tapšanas principu, kas cilvēkam l̦auj sajust sevi vairs ne kā indivīdu, bet gan kā „vienu Dzìvo”, 24 ar kura iznīcināt- un radītprieku cilvēks ir saplūdis.

Niče raksta, ka „mēs esam iepazinuši dionīsisku fenomenu, kas ikreiz no jauna kā pirmatnējas patikas izvirdumu atklāj mums individuālās pasaules rotal̦īgo uzcelšanu un sagraušanu, līdzīgi kā „tumšais” Hērakleits pielīdzina pasauli veidojošu spēku bērnam, kas rotal̦ājoties pārvieto akmeṇus, būvē un atkal sagrauj smilšu pilis”. ${ }^{25}$ Kā Nīče vēlāk atzīmēs darbā „Ecce homo”, ${ }^{26}$ Hērakleits, kura tuvumā vin,am top siltāk un labāk nekā jebkur citur, ir pēdējais no pirmssokratiķiem, par kuru vin,am bijušas kaut kādas šaubas jautājumā par to, kas attiecas uz dionīsisko. Dionīsiskās filosofijas galvenais motīvs ir saistīts ar mūžīgās tapšanas baudu, kas sevī ietver arī iznīcināšanas baudu, - tā ir „Jā-teikšana” dzìvei visā tās košumā.

Būtībā par dionīsisko Nīče sauc dzīves apliecinājumu, „Jā-teikšanu” dzīvei visās tās grūtībās, šausmās un nezināmākajās problēmās, un ne jau tāpēc, lai atbrīvotos no visām šausmām, grūtībām un līdzcietības, lai izlādējoties attīrītos no bīstamiem afektiem, bet gan, lai par spīti šausmu un līdzcietỉbas 
robežām, varētu pats būt mūžīgās tapšanas prieks un līksme, tas ir tāds prieks un līksme, kas sevī ietver arī iznīcināšanas prieku. Šìs pārdomas Nīče noslēdz ar vēstījumu, ka viņš ir pēdējais filosofa Dionīsa māceklis. ${ }^{27}$

Jautājumā par dzīvi Ē. Fromms darbā „Cilvēka sirds” raksta, ka to var pieredzēt vien tās atseviškajās izpausmēs - tik pat labi kā indivīdā, tā arī putnā vai, piemēram, puḳēe. ${ }^{28}$ Šāda pieredze, pēc Fromma domām, ir pretstats atsvešinātai, deformētai, neīstai, sagudrotai pieredzei jeb tādai pieredzei, kas būtu atbilstīga homo mechanicus, homo consumens pieredzei. Būtībā tā ir tieša, nepastarpināta, pilnvērtīga pasaules aptvere, „šāds pasaules skatījums pastāv agrā bērnībā līdz brīdim, kad tas mainās izglītības iespaidā". ${ }^{29}$ Šajā brīdī ir vērtīgi atzīmēt vēl kādu būtisku Fromma norādi, - ka cilvēks šajā pasaulē tiek iemests ne pēc paša gribas, tāpat arī viņa aiziešana no tās nenotiek brīvprātīgi. Taču tikpat nozīmīgi ir aptvert, ka dzimšana, kas savā ziṇā cilvēku „iemet” šajā pasaulē, Fromma uzskatos nav tikai viens akts. Dzimšana, viņš raksta, ir process, kas „nozīmē piedzimt ik brīdi. Nāve iestājas mirklī, kad apstājas dzimšana" ${ }^{30}$

\section{NOSLĒGUMS}

Lai gan $\overline{\mathrm{E}}$. Fromma darbos Nīče un viṇa idejas parādās reti un epizodiski, tomēr atsevišķ̧os šo domātāju tekstu fragmentos un domu uzplaiksnījumos ir iespējams pamanīt kopīgas idejiskās paralēles. Tā, piemēram, abi domātāji savā ziņā ir vienprātīgi jautājumā par Rietumu cilvēka un Rietumu sabiedrības stāvokli, kādā cilvēks nonācis ı9. gadsimta industrializācijas un birokratizācijas ietekmē. Abi domātāji to raksturo kā dzīves panīkumu, cilvēka atsvešinātību no sevis, automatizāciju, kḷūšanu par lietu.

Šādu atsvešinātu, automatizētu cilvēku un dzìves panīkušu sabiedrību ir radījusi Eiropas un Ziemel̦amerikas birokrātiski industriālā sabiedrība, kuras saknes lielā mērā ir 19. gadsimtā. No sevis un citiem cilvēkiem atsvešinātie cilvēki tādējādi kḷuvuši par homo consumens vai homo mechanicus tipu pārstāvjiem, kuru vienīgā jēga ir vai nu tērēt vai arī pašiem tikt tērētiem, piemēram, tikt uzskaitītiem kā vienībām, kā lietām, pret ko arī attiecīgi izturēties kā pret patēriņa preci, patērējamu lietu.

Taču šķiet, ka tas nebūtu iespējams, ja tas nebūtu vajadzīgi un noderīgi tādai indivīdu un locekḷu vienībai, ko dēvē par sabiedrību. Proti, katra 
sabiedrība attīsta sev noderīgus dzīvošanas model̦us, lai radītu un nostiprinātu sabiedrības raksturu. Bet, lai varētu nodrošināt sabiedrības rakstura pastāvēšanu, sabiedrība rada sava veida filtru, kas ir kā "pārbaudes akmens” ikvienam sabiedrības loceklim, kas grib pārliecināties par savu derīgumu vai nederīgumu kādai konkrētai sabiedrībai.

Taču tā kā sabiedrība, izmantojot sociālo filtru, liek tās loceklim gribēt darìt tās lietas, kas ir pieņemamas un vajadzịgas sabiedrībai, turklāt tā - it kā šis loceklis pats būtu izvēlējies tā rīkoties, tad šis filtrs būtībā rada un nosaka indivīdu kā nebrīvu būtni. Kā atzīmē Fromms, lielā mērā šāda indivīda pakḷaušanās sabiedrībai skaidrojama ar bailēm no vientulības, kas ir bailes no sociālas izolācijas, sociālas nomiršanas. Taču par sociālas nāves aktu kā novēršanos no sabiedrības vedina domāt gan Fromma, gan Nī̌̌es rakstītais. Proti, Fromms rosina būt drosmīgam, rīkojoties atškkirīgi no sabiedrībā pieņemtās uzvedības, savukārt Nīče to apraksta kā gara triju pārvērtību norisi, proti, kā gars kḷūst par kamieli, kamielis par lauvu un visbeidzot - kā lauva kḷūst par bērnu. Šḳiet, ka galvenā doma ir saistīta ar to, ka indivīdam ik pa laikam ir derīgi atiet malā no sabiedrības, „atmest” sevi, lai pārbaudītu lietas, sabiedrības temperatūru un noskaidrotu, vai tās vērtības, ar ko dzīvo sabiedrība, vēl ir vērtīgas, jo, ja tā nedara, tad cilvēkam var gadīties nodzīvot dzīvi savā ziṇā tādā kā pusnomoda (Ē. Fromma lietots jēdziens half awake darbā „Māksla būt” ${ }^{31}$ ) stāvoklī.

Runājot par būšanu drosmīgam pret sabiedrības prasībām, der ņemt vērā $\bar{E}$. Fromma domu par piedzimšanu, kas nav vienreizējs akts. Proti, dzimšana ir process, kas nozīmē piedzimt ik brīdi. Tas savā ziṇā sabalsojas ar būšanu dionīsiskam ik brīdi - būt gatavam atmest savu „ego”, savu „Es” (kam nozīme ir tieši konkrētā sabiedrībā), lai l̦autos dionīsiskās tapšanas "Jā-teikšanai” dzīvei, procesam, kurā „mirt” un „rasties” ir viens un tas pats, kas savukārt ir kaut kas cits nekā tas, ko grib, un kas no cilvēka kā sabiedrības locekḷa ir vajadzīgs sabiedrībai, kas savas vajadzības ir noteikusi filtrā, kura darbïbas rezultāts ir nāve, kas iestājas mirklī, kad apstājas dzimšana. Tāpēc būtiska ir cilvēka spēja un pat vajadzība ,atiet malā” no sabiedrības, atmetot sevi, uz ko vedina Nī̌e, kurš savā filosofiskajā domā galvenos uzsvarus liek uz dionīsisku būšanu, kas nozīmē cilvēka spēju pazaudēt sevi, lai atkal rastu un radìtu sevi no jauna. 


\section{Vēres}

I Sk.: Safranski R. Nietzsche: Biographie Seines Denkens. München: FISCHER Taschenbuch, 2000, S. $320,323$.

2 Fromms E. Psihoanalīze un dzenbudisms. / Tulkojusi A. Šuvajeva. Rīga: Zvaigzne ABC, 2002, 29. .lpp. (Piezīmē Ē. Fromms norāda arī uz šiem kritiskajiem novērotājiem. Starp vairākiem viṇa norādītajiem uzvārdiem minēts arī Nǐče.)

3 Turpat, 29.-30. lpp.

4 Nīče F. Tā runāja Zaratustra. Grāmata visiem un nevienam /. Tulkojis I. Šuvajevs. Rīga: Zvaigzne ABC, 2007, i4. lpp.

5 Turpat.

6 Safranski R. Nietzsche: Biographie Seines Denkens, S. 23 I.

7 Patērējošais cilvēks. Sk.: Fromm E. The Heart of Man. Its Genius for Good and Evil. New York: Harper \& Row, I971, p. 64.

8 Turpat, p. 64, 65.

9 Turpat, p. 63.

Io Turpat.

II Turpat, p. 63.

I2 Nietzsche F. KSA. Bd. 6, S. I38.

I3 Fromms E. Psiboanalize un dzenbudisms, 53. lpp.

14 Turpat, 58. lpp.

I5 Turpat, 52. lpp.

16 Turpat, 59. lpp.

17 Turpat, 4I. lpp.

I8 Nīče F. Tã runāja Zaratustra. Grāmata visiem un nevienam, 22.-25. lpp.

I9 Sal.: Fromm E. The Art of Being. London: Constable, 1993, p. 24.

20 Fromms $\bar{E}$., Psihoanalize un dzenbudisms, 30. lpp.

2I Turpat, 6r. lpp.

22 Turpat, 61.-62. lpp.

23 Nīče F. Traǵédijas dzimšana no mūzikas gara jeb: griek̦i un pesimisms. / Tulkojis I. İjabs. Rīga: Tapals, 2005, 37. lpp.

24 Nietzsche F. KSA, Bd. I, S. ıо9.

25 Niče F. Traǵédijas dzimšana no müzikas gara jeb: griek̦i un pesimisms, 154. lpp.

26 Nietzsche F. KSA, Bd. 6, S. 312, 313.

27 Sk. turpat, S. I6o.

28 Fromm E. The Heart of Man. Its Genius for Good and Evil, p. 63.

29 Fromms E. Psihoanalizze un dzenbudisms, 87. lpp.

30 Turpat, 38.-39. lpp.

31 Fromm E. The Art of Being, p. 34. 


\section{Māris Kūlis}

\section{Kas ir patiesība? Ēriha Fromma modelis}

Jautājums „Kas ir patiesība?” saskaras ar interesantu dīvainību. Proti, šķiet, ka patiesība ir kaut kas tāds, par ko nevajadzētu būt šaubām. Ja reiz ir patiesība, tad tai vajadzētu būt skaidrai un gaišai. Tikmēr maldiem būtu jābūt tādiem, kas visu sarežğgi un aizmiglo. Tomēr jādomā, ka arī pati patiesība var būt dažāda - vai vismaz uz to var skatîties no dažādiem redzespunktiem. Vai mana patiesîba ir patiesība arī kādam citam? Ja es maldos, vai kāds cits nemaldās? Vai visiem var būt viena patiesība? Tie ir jautājumi, kas saskaras ar būtiskiem patiesỉbas koncepta izpratnes meklējumiem. Proti, tas ir jautājums par principu - atzīt Absolūta pastāvēšanu, universālo iedabu, kas cieši skar patiesības pamatproblēmu.

Pati ideja par Absolūtu nav itin nekas jauns Eiropas filosofiskajā domā. Tā ir ideja par kāda universāla un mūžìga atskaites punkta esamību, bez kura jebkas cits ir tikai relatīvs. Absolūts nodrošina universālas, nemainīgas, pēdējās patiesības iespējamību. Tātad šķitums būtu vien gaistošs moments, kura nozīmība būtu stipri apšaubāma. Var pat apgalvot, ka Absolūta ideja ir devusi lielu ieguldījumu mūsdienu zinātnes virzībā. Tomēr ir vērts pajautāt vai ši ideja ir vienmēr piemērota un laikmetīga?

Jautājumi par Absolūtu kā pamatu patiesībai skar būtisku cilvēka dzīves orientieri, kas nosaka ne tikai indivīda dzīves piepildīîibu un spēju darboties, bet arī (plašākā mērogāa - visas sabiedrības (it îpaši zinātnes) spēju meklēt zināšanas un veidot attieksmi pret vērtîbām.

Filosofiskais jautājums par Absolūtu ir vistiešākajā veidā saistīts ar jautājumu par patiesību. Ja pasaule, kurā tiek atzīta Absolūta esamība, tiek 
saprasta kā noturīga un pārlaiciska, vai tad arī patiesība ir noturīga un universāla? Savukārt, ja realitātes izpratne pauž tādu nostādni, kurā katrs elements ir dinamisks, vai tad jāmeklē cits patiesības un zināšanu skaidrojums? Dzịlı psihologa un pētnieka Ēriha Fromma meklējumi atrodas uz robežas, kas aplūko šo divu model̦u iespējamību jautājumā par patiesību.

Jebkurā mēgénājumā klasificēt patiesības teorijas nepieciešams norādīt uz atškikirību starp tām. Tas nozīmē, ka aplūkotajās teorijās un virzienos jābūt kādai nozīmīgai atšksirībai, kas aplūkotās teorijas liek uzskatīt pat par pretrunīgām.

Viens šāds mēgeinājums var sākties ar noskaidrošanu, cik izplatīts ir patiesības lietojums? Proti, jautājums ir šāds: cik plašā apjomā kāda patiesība vai tās veids un kā domāt par patiesību ir aktuāls? Viens veids, kā domāt par patiesību, ir uzskatìt to par personisku patiesību. Tādas patiesības ir subjektīvi uzskati par kādu lietu kārtību. Šo uzskatu pamatojums ir rodams tikai subjekta paša pieredzē un atspoguḷo psihologiska rakstura iezīmes. Šāds skatījums pēc līdzības ieklauj arī divus citus veidus. Subjektīvās patiesības var sakrist arī vairākiem subjektiem. Šāda veida patiesību varētu saukt par sociālo patiesību. Tāda patiesība ir uzskati lielākas vai mazākas grupas ietvaros, kurus tā tur par patiesiem. To pamats meklējams noteiktas grupas vēsturē, vidē, kultūrā u. tml. Grupas ietvaros patiesības garants rodams tradīcijās. Tradīcija nav apšaubāma un kalpo par atbalsta punktu pastāvošajām vērtībām. Šādas grupas robežas nav stingri noteiktas, lai gan bieži tās varētu tādas būt. Te drīzāk ir runa par kādai kopienai kultūrā un tradīcijā piemītošiem aksiomātiskiem uzskatiem.

Pèc savas uzbūves līdzīgs iepriekšējam ir tāds patiesības veids, kas pārstāv visu cilvēku sugu. Tās ir patiesības, kas ir tieši atkarīgas no cilvēku tipiskas psihiskās un fizikālās uzbūves principiem. Mēs itin neko nevaram zināt par, piemēram, Dieva skatpunktu uz tiem jautājumiem, kas mūs - cilvēkus nomoka. Tā ir principiāla un fundamentāla atšksirība, kuras robežas nav pārvaramas.

Fundamentāli citāds ir tāds patiesības definēšanas mēgeinājums, kas pārklāj gan katra atseviškła indivīda, gan grupas pieredzi, kultūru, tradīciju. Šāda veida patiesības varētu saukt par universālām vai absolūtām patiesībām. Tās ir tāda veida uzskati, kurus pēc nelielas vai ilgākas apdomas vajadzētu pieņemt piln̄igi jebkurai būtnei. Universālo vai absolūto patiesību fundamentāla 
iezīme ir to pārlaiciskums. Tas nozīmē, ka $x$ ir patiess neatkarīgi no individuālajām tā uztveres vai domāšanas īpatnībām. Šādas patiesības vienīgais atskaites punkts ir pati esamība par sevi. Absolūtā patiesība „atskaitās” tikai realitātes priekšā un pieņem, ka šāda realitāte, kas ir stabila, patiešām eksistē. Tas ir pieņēmums, ka viṇpus cilvēka (u.c. iespējamo subjektu) uztverei eksistē kāda noturīga pasaule, to var dēvēt arī par objektivitāti. Tiesa, var izrādīties problemātisks apsvērums, ka universālās patiesības pieņemtu tikai visas racionālās būtnes, kuras domā noteiktā veidā. Tā kā cilvēkiem nav priekšstata par kādu citu iespējamu racionalitāti, realitāti u.tml., tad vismaz hipotētiskā līmenī var atstāt šaubu ēnu par universālisma pretenzijām.

Dažādo patiesības teoriju sadursmes punkts te atklājas gaužām skaidri, taču tā plašākās dimensijas ir grūti noskaidrojamas. Izšķirošs ir jautājums, vai patiesībai pēc savas iedabas piemīt universāla vai vēsturiska iedaba? Šajā gadījumā var arī teikt: vai patiesība ir universāla vai partikulāra - vai tā ir visiem un vienmēr aktuāla, vai arī tā var būt aktuāla vienam vai vairākiem, kamēr citiem tā tāda nav.

Tas nav jautājums, vai patiesība kalpo par kādu orientieri un tādējādi pastāv kā abstrakts, absolūts mērḳis, vai arī, ka patiesību var izteikt tikai kā izteiksmes formu un tātad arī raksturot kā mūžīgu. Jautājums atrodas kaut kur pa vidu starp formu un saturu. Tā ir dinamika, kuru, no vienas puses, uztur slēptas (vai dažkārt pietiekami atklātas) alkas pēc tāda satura, kas reizi par visām reizēm ieviestu kārtību. Taču, no otras puses, spriedzi uztur apjausma par „dievu nāvi”, t.i., par skaudro nojēgumu, ka dzīves īstenība parādās kā tik sarežğìta, mainīga un konfliktējoša, ka katram universālismam jāatkāpjas, pirms tas nav kḷuvis par izsmiekla objektu.

Divu Latvijas pirmskara domātāju - Paula Dāles un Konstantīna Raudives - viedokḷ dinamika ${ }^{1}$ parāda to jautājumu spektru, kas nomoka lielu daḷu patiesības filosofiskās izpētes entuziastu. Epistemologijas prasību iegrožotā apziṇa meklē patiesību, apskata tās veidošanās noteikumus, saistot patiesību ar drošticamu izziņu.

Taču pagrieziens ideju vēsturē, kas paver iespēju rasties šaubām par patiesības universālismu, iespējams, sakrīt ar cilvēka eksistenciālās situācijas izpratnes maiṇu 2o. gadsimta sākumā. Priekšplānā parādās sapratne, ka cilvēks ne tikai grib izziņā iegūt abstrakti pareizu patiesību, bet grib tajā arī dalīties. Tas ir laiks un filosofisko pārdomu konteksts, kura ēnā dzīvo un 
domā arī Ērihs Fromms. Citiem vārdiem sakot, tas ir domas cel̦š no izziṇas patiesības uz saskarsmes patiesību, no absolūtās uz optimālo patiesību.

Šis pagrieziens filosofijas vēsturē sakrīt ar filosofijas aiziešanu no jaunlaiku epistemologiski ievirzītā domāšanas veida uz eksistenciālisma un intersubjektivitātes problēmām. Ja patiesību neizdodas iegūt izziṇā, tas nenozīmē, ka cilvēks to nemeklē; cilvēks tikpat vēlas saprast sevi un tikt saprasts komunikācijā. Apziṇas koncepts nonāk konfrontācijā ar sirdsapziṇu. Consciousness (apziña - angḷ. val.) atgriežas pie vārda saknēm; pie latīniskā con scientia.

Savukārt conscientia ir citāda apziṇa, citāda zināšana. Tā ir „zināšana kopā ar" - ar zināšanām, ar citiem, ar kopīgo. Zināšanas tiek norautas no troņa un nodotas publiskai lietošanai. Tas paver durvis skepticismam un apjukumam, ko tie, kas uzticas mūžīgajam, Absolūtam, var vienīgi nopelt. „Ir skeptiķi, kas apšauba lielas un nozīmīgas realitātes, vērtības un idejas tikai tādēḷ, ka šīs lietas nav saskatāmas kā uz delnas, nav viegli tveramas, prasa lielu gara koncentrāciju, ilgstošu iekšēju piepūli," ${ }^{2}$ raksta Pauls Dāle, piebilstot, ka šì nelaime rodas no „intelektuāla slinkuma”.

Tas pats notiek ar lielo patiesību un metafizisko īstenību meklēšanu: „Daudzi šaubās par augstāku īstenību, metafiziskām lietām, absolūtu prasību nozìmību tikai tāpēc, ka tas runā pretim viņu tieksmei dzīvot un domāt pēc pašu patikas un patval̦as, nesaskan ar viṇu hedoniskām dzin̄ām pēc ērtībām un baudas." Ja kādas šaubas ir piel̦aujamas, tad tikai tālab, lai ar pareizi vadītu prātu skaidrinātu tos apvāršņus, kas aizsedz mūžīgo patiesības gaismu. Pauls Dāle iezīmē tādu skatījumu, kas pārpasaulīgo, pārlaicisko un noturīgo vērtē augstāk par individuālām alkām un dziṇām.

Taču pārāk skaidra dzīve vismaz dažiem nešķiet nemaz tik simpātiska. K. Raudive atgādina, ka šāda ceḷa ēnas puse ir tas, ka „iznīcina dzīva cilvēka vērtību”. Zinātnes valoda, zinātnes konstrukcija, izmisīgie sholastiskie pūliṇi, kas pielikti, lai veidotu visaptverošas sistēmas, sāk zaudēt savu atgriezenisko saiti. Raudive, pārdomājot sava laika garīgo situāciju, ierauga un izsaka to, kas zinātni nomoka jau kopš izseniem laikiem. Tas ir mūžsenais konflikts starp kustīgo un nekustīgo, starp laicīgo un mūžīgo, kur ,patiesība nerespektē ne jūtīgumu, ne ciešanas, ne pārdzīvojumu. Tā sava kategoriskā prasījuma dẹl, gatava iznīcināt mūsu subjektīvo dzìvi, tā tiecas ieskatīt lietu galīgo būtību." ${ }^{2}$ Viņš izsaka apgalvojumu, kas prasa lielu uzdrīkstēšanos: „Patiesības iejaukšanās cilvēka dabā ir nodarījusi vairāk l̦auna nekā laba." ${ }^{5}$ 
Dzị̣̂u psiholog̣ijas un psihoanalīzes uznāciens Eiropas intelektuālajā telpā 20. gadsimta sākumā lieliski saskan ar Raudives teikto. É. Fromms raksta par cilvēka domāšanu un patiesības meklējumiem: „Mūsu apzinātie motīvi, idejas un uzskati ir nepatiesas informācijas, neobjektivitātes, iracionālu kaislību, racionalizācijas, aizspriedumu sajaukums, kurā patiesības drusciņas klīst riṇkī un dod maldīgu mierinājumu, ka viss šis sajaukums ir reāls un patiess. Domāšanas process cenšas sakārtot visu šo ilūziju atkritumu tvertni saskaņāa ar iespējamības likumiem. Šim apzinas līmenim vajadzētu atspoguḷot realitāti; tā ir karte, kuru izmantojam, lai organizētu savu dzìvi.” Psihoanalīzes atklājums, ka cilvēks ir ne tik daudz racionāla kā jūtoša, alkstoša, dziņu tirdīta būtne, daudziem ir liels pārsteigums. Tas ir satricinošs pavērsiens noturīgas racionalitātes meklējumos.

Pārdomas par patiesības un daiļuma tēmu vedina Raudivi, kurš ievērību Latvijā izpelnījies nevis ar arhivāra vai log̣iḳa darbu, bet gan ar kultūras norišu trāpīga vērotāja spējām izdarīt pretenciozus secinājumus: patikas un dailuma idejas aiziešana otrajā plānā vedusi Eiropu uz tās norietu. Tas noticis tādēl, ka cilvēks pazaudējis savu iedabu un pārdzīvojumus aiz t. s. pelēkās teorijas. Bet cilvēku tā rīkoties, kā uzskata Raudive, „pamudina tā saucamais patiesības kults, kas rada tās teorijas, kas vairāk kalpo dažādiem škitumiem un maldiem nekā pašas patiesības atklāšanai un tās dabas izskaidrošanai".7

Ja pasaules uzskats draud pārvērsties absurdā un noliegt īstenas dzìves piepildijumu, var vien pievienoties Nī̌es bargajam spriedumam par patiesības pretenzijām: „Dabā nav nekā tik peḷama un niecīga, ko maza ši izziņas dvesma tūdal nepiepūstu kā pūsli." ${ }^{\prime \prime}$ Patiesības teoriju plejāde, kur katrai ir kādi nopietni trūkumi, bet katra solās paveikt ne tikai to, ko spēj, bet arī to, ko nespēj, kur katra ir „piepūtusies kā pūslis”, drīzāk atgādina tirgus laukumu: bodnieki skaḷās balsīs visādi liela savu preci un sola, ka tā nu būs îstā. Tirgoṇi viens par otru skal̦āk mēǵina iesmēerèt savu preci, kas spoži izlikta uz letes. Tomêr nevar zināt, vai tas, kas nokḷūs iepirkumu maisiṇā, vēlāk izrādīsies lietojams. Dažkārt tas var nebūt isstais, bet dažkārt tam var būt beidzies lietošanas termiṇš. Tikmēr pircējs lielajā steigā starp citiem l̦audīm un vispārīgā jūklī, kur garām zib grezni izpušķoti piedāvājumi, drīzāk var apjukt nekā pamanīt viltojumus.

Dāles un Raudives teiktais ir norāde uz filosofisko un kultūras norišu pārmaiṇām. No vienas puses, tās ir alkas pēc stabilitātes un mūžĩgā. Taču 
pretējais ir dzīvāks - un šim dzīvīgumam tiek pieškirta liela vērtība. Tāa ir kultūras sadrumstalotības diagnoze, viss viens, vai pie vainas ,intelektuāls slinkums”, vai arī, kā to saka Raudive, „civilizācija ir pārprastā patiesības kulta sekas”. Absolūtās patiesības ideāla jeb „patiesības kulta” produkts civilizācija ar visām tās sliktākajām izpausmēm - agresivitāti, dekadenci un skepticismu - tomēr turpina pastāvēt un arī tajā ir kaut kāda jēga. Kā izturēties pret šo fragmentāciju? Vai atmest patiesību kā liekvārdību vai varbūt turpināt centienus reabilitēt Absolūto?

Neviena no šīm atbildēm nešksiet daudzsološa, jo atbildes vietā piedāvā vien norobežošanos. Par šādas kultūras un ideju situācijas cilvēkiem Nīče saka, ka vin,i ir „nevis cilvēki, bet tikai iemiesoti kompendiji un it kā konkrētas abstrakcijas”. ${ }^{10}$ Nīče turpina: „Viṇi ir kaut kas cits: ne cilvēki, ne dievi, ne dzīvnieki, viṇi ir vēsturiskās izglìtības produkti, caurcaurēm izglìtỉba, tēls, forma bez pierādāma satura, diemžēl - tikai slikta forma, kas turklāt ir uniforma." ${ }^{11}$

Nī̌ces teiktais reti kādam var škist glaimojošs, tomēr neatstāj nojausma, ka tieši viņš ir viens no tiem, kas par to, kas ir, saka, kā tas ir. Tieši tādēl viņš ir neērts domātājs, kuram piekrist labākajā gadījumā drīkst tikai zagšus. Vai tiešām modernais cilvēks ir vien tēls un uniforma, kas, patiesības kulta dzìts, sapinies savā meistarībā un alkās pēc Dieva troṇa iztēlojies, ka var pārvarēt savu laiciskumu un vēsturiskumu?

Abu Latvijas pirmskara laika domātāju pārdomas iezīmē būtisku sadursmes vietu filosofisko ideju laukā. Vin,u pozīcijas raksturo noš̌kīirumu starp Absolūto, pārlaicisko, no vienas puses, un laicīgo, mainīgo, vēsturisko, no otras puses.

Šo izškiriršanos patiesības izpratnē - kurp iet?, pa vienu vai otru cel̦u? aplūko arī dzịl,u psiholog̣ijas pētnieks un praktizētājs Ērihs Fromms. Viņš jautājumu par patiesību neskata kā ideālists - filosofs metafiziķ̣is. Viňš šai tēmai nepieiet arī kā valodnieks vai loğiksis. Ė. Fromma interese vērsta galvenokārt uz cilvēka vietu pasaulē un cilvēka attieksmi pret pasauli. Jāṇem vērā, ka Fromms ir nevis zinātnieks, bet gan dvēseles dzịlu pētnieks. Viņa uzmanības centrā ir jautājums par to, kā cilvēkam labāk, tas ir - optimāli rīkoties pasaulēe Viņš nevēlas runāt par patiesību kā par metafizisku konceptu vai par kādas pēdējās patiesības iespējamību. Fromms pats norāda, ka salīdzinājumā ar realitātes adekvāta uztvēruma izskaidrošanu metafiziskie pārspriedumi ir abstrakti un nesvarīgi. 
Ė. Fromms runā par patiesību tādā aspektā, lai uztvertu šeit un tagad nozīmīgo, lai patiesība būtu optimāla un atbilstoša situācijai un vajadzībām. Viṇš nevēlas patiesības jēdzienu aplūkot no Eiropas filosofijas vēsturē tik ierastās pozīijas, kas priekšplānā izvirza alkas pēc universālijām un absolūtās patiesības. Fromms uzskata, ka šãda pieeja nespēj sniegt pilnvērtīgu orientieri cilvēka dzīvē un attiecībās ar appasauli (Umwelt). Viña pieeja patiesības izpratnei ir atšifrējoša un atklājoša. Fromms absolūtai patiesībai pretstata citu, viņaprāt, precīzāku patiesības modeli - optimālo patiesību. Viņšs priekšplānā izvirza nevis alkas pēc pārpasaulīgās un atsvešinātās pasaules, bet gan aplūko klātesošo pasauli. Tātad var secināt, ka Fromms uzsvaru liek nevis uz tādu patiesību, kas būtu pārcilvēciska, bet gan uz to, kā kāda patiesība darbojas. Vārda „optimāls” lietojums paredz, ka nevis kāda patiesība ir patiesa un cita nepatiesa, bet ka paralēli var pastāvēt vairākas patiesỉbas. Taču kāda viena būs „optimāla”, proti, kāda viena spēs sniegt labāku rezultātu un vairāk ieguvumus.

$\bar{E}$. Fromms priekšplānā izvirza pamošanās līdzību. Viņš runā par nemitīgu tuvošanos patiesībai kā fikciju un ilūziju samazināšanai. Tā ir līdzība ar atmošanos - māṇu un sapņu nomešanu, atbrīvošanos no tiem. Patiesības būtỉbas un kritēriju iztirzāšana ir vien sekundāra nodarbe, kas diez ko nelīdz centieniem labāk orientēties pasaulē. Turpretīi iūziju nomešanai ir tūlītējs un klātesošs efekts. Fromms uzsvaru liek uz efektivitāti - patiesība nevis ir, bet tā darbojas priekš kaut kāa. Jān, nem vērā, ka Fromms ir nevis filosofs, bet gan dzị̣,u psihologíijas pētnieks. Tātad viṇa uzdevumi ir pavisam citi. Viṇš priekšplānā izvirza jautājumus - kā cilvēkam būt un rỉkoties pasaulē, kā uzñemties atbildību pašam par savu dzìvi.

Aplūkojot ētikas tēmas, Fromms pievēršas absolūtā un optimālā attiecībām. ${ }^{12}$ Viṇš norāda uz tādu pazīmi, ka uz absolūtām vērtībām atsaucas êtiskās koncepcijas, kuras pastāv autoritārās sistēmās. Te patiesības kritērijs sakrīt ar varas autoritāti. Autoritāte jau arī to nozīmē, ka tā uzskata sevi par pārvēsturisku un nekḷūīigu. Autoritāte pasaka priekšā - kā jārīkojas. Tā no ārpuses dod norādījumus un izstrādā likumus, kuriem jādarbojas vienmēr un visur.

Turpretī brīvs cilvēks ir tāds, kurš̌ ir spējīgs pats uz savu atbildību izdarīt izvēli. Lai gan absolūtā patiesîba pretendē uz valdnieka vietu, cilvēkam pašam ir jānoskaidro, vai tā ir arī optimālā patiesîba.

Šāds patiesibas skatijums liek Fromma pieeju ievietot starp tiem patiesỉbas modeliem, kas patiesîbu aplūko kā vēsturisku. 
Dzịl,u psihologijas pētnieka Fromma idejā par optimālo patiesību saskatāma līdzība ar pragmatisma teorijas patiesības skaidrojumu. Pragmatisma teorijas ${ }^{13}$ pamatā ir atziņa par patiesības derīgumu. Pragmatismā - mācībā par pielietojumu un derīgumu -, lìdzīgi kā rīkojas Fromms, it kā atsakās no ierastajiem mèginājumiem nokḷūt pie kādas pēdējās patiesības un problēmai pieiet no pavisam citas puses. Proti, tā nevis no nezināmā tiecas pie zināmā (patiesības), bet otrādi - no patiesības noskaidro kaut ko par nezināšanu. Ja kādas patiesības labi funkcionē, dod labumu, darbojas, izskaidro, tad tās ir patiesas. Nav nekādas nozīmes, vai patiesība tiešām ,ir patiesa”. Vienīgais, kas mums pieejams, ir tas, ka patiesība strādā vai nestrādā.

Šādā griezumā var apšaubīt to, vai pragmatisma patiesības izpratne vispār ir uzskatāma par patiesības teoriju. Proti, citu teoriju kontekstā tā nemaz necenšas noskaidrot pašu patiesību. Tā izmanto citu patiesības noskaidrošanas paṇēmienu rezultātus un pēcāk izvērtē to derīgumu. Tādējādi pragmatisms drīzāk nevis pats tiecas noskaidrot patiesību, bet gan nodarbojas ar patiesības izziņas praktiskajām sekām. Pragmatisma teoriju var izteikt ar piemēru. Ja man šķiet, ka tas ir galds, tad vienalga, vai tā ir vai nav realitāte. Daudz svarīgāk ir pamēgénāt uzlikt uz šì galda kafijas krūzīti. Ja gadīsies tā, ka krūzìte galdam izkritīs cauri, tad man jādomā, ka tā gluži nebija patiesība, ka tas ir galds.

Pragmatisma teorijas visai triviālais, bet pievilcīgākais aspekts ir tas, ka tā ir viegli izmantojama. Proti, saskaņā ar šo teoriju, nav iespējams pilnīgi visu pārbaudīt. Mums ir jāuzticas, ka viens vai otrs ir patiess. Piemēram, man nav katru reizi jāiet pārbaudīt visus pulksten,us. Man jāuzticas, ka vairāk vai mazāk visi rūpējas par patiesību. Kādēḷ? Tāpēc, ka patiesība nodrošina lietu veiksmīgu funkcionēšanu. Ja gadās, ka kaut kas nestrādā, tad pūlis to pieregulēs.

$\overline{\mathrm{E}}$. Fromma pārdomās izteiktais optimālās patiesības modelis vedina indivìdu izvērtēt patiesības iedarbīgumu un noderīgumu savas dzīves norisēs. Lìdzīgā veidā pragmatisms uzdod jautājumu: pieņemot idejas patiesumu, kādu atšķirību šis patiesības moments ienes mūsu aktuālajā dzīvēe Tas ir pavisam cits veids kā skatīties uz izteikuma un realitātes attiecībām. Lietas un idejas saskaņa (atbilstîbas teorija) te nozīmē ko citu - t.i., jebkuru procesu, kas ved no idejas pie kāda notikuma nākotnē, ja tikai šis process norit veiksmīgi.

Šis process ir arī idejas pārbaude jeb patiesības tapšanas process. Idejas kḷūst patiesas tikai praksē vai darbībā. Patiesu ideju no nepatiesas atšk,kir idejas veiksmīgas praktiskās sekas. Ja šādas veiksmīgas sekas iztrūkst, tad ideja 
nav patiesa. Citiem vārdiem sakot: ideja ir patiesa, ja tā ir derīga. Derīgs ir tas, kas ir īstenojis savu uzdevumu, un patiesa ideja issteno savu uzdevumu labāk nekā nepatiesa. Tādā gadījumā patiesība ir nevis statiska norma, bet tā atrodas nepārtrauktā izmaiṇu procesā. Ja tiek atrasta cita ideja, kas ḷauj veiksmīgāk pāriet no viena paredzējuma pie otra, tad tā kḷūst patiesa, bet iepriekšejā zaudē savu patiesumu. Patiesa ideja ir patiesa tikai tik ilgi, cik tā ir derīga. Patiesība nav pašmērḳis, tā ir līdzeklis citu dzīves vajadzību apmierināšanai. Patiesa doma ir derīga, jo tās objekts ir derīgs. Patiesība atmaksājas un tāpēc uz to tiecas. Mūsu pienākums meklēt patiesību izriet no kopīgā pienākuma darīt to, kas atmaksājas, dod labumu, piepilda dzìves vajadzības. Idejas un teorijas ir instrumenti, lai padarītu dzīvi „labāku”, baudāmāku vai produktīvāku, un ir patiesas tikai tik daudz, cik piepilda to.

Pragmatismu iezīmē būtiskas atšķirības no tām patiesības teorijām, kuras patiesību raksturo no universālisma pozīcijām (patiesības atbilstības un saskaņotības teorijas). Proti, pragmatisms pieņem, ka patiesība nemitīgi ir tapšanā un balstās kopīgā pieredzē. Patiesība nepastāv pirms pieredzes.

Patiesības teorijas, kuru pamatā ir ideja par Absolūtu, turpretī norāda, ka patiesība pastāv neatkarīgi un attiecas uz lietu dabu. Pragmatismā patiesībai pašai par sevi nav itin nekādas vērtības, bet Absolūta idejā balstītās teorijās tā ir galvenā vērtība. Pragmatismā patiesība ir balstīta kolektīvā rīcībā, bet atbilstîbas teorijā - tā ir neatkarīga no laika un vietas untumiem. Tas lauj izturēties pret aptuvenību, nepilnīgumu un neobjektivitāti kā būtiskām patiesības koncepta sastāvdal̦ām: patiesība ir saskaņa starp neprecīzu apgalvojumu un kādu ideālo robežu.

Lai gan Fromma optimālās patiesības modelis un dažas pragmatisma idejas ir visai tuvas, nevar teikt, ka ar to aprobežojas visas dzịlu psihologa idejas. Fromma ideja par optimālo patiesību nav tikai individuālas dzīves veidošanas instrukcija. Šì ideja saprotama arī plašākā nozīmē. Proti, cilvēku var skatīit arī sabiedriskā līmenī, kur izziṇa realizējas kā zinātne. Fromms norāda, ka zinātne jāsaprot ne tikai kā zināšanu kopums, bet arī kā institucionalizēta, organizēta norise ar noteiktiem mērķiem, ideāliem un, kas ir svarīgi, ar sākotnējām ievirzēm. Zinātnes ievirze ir skatāma kopsolī ar individuāla cilvēka pamatnostādnēm, proti, tajā atbalsojas - kā patiesība tiek saprasta individuāla cilvēka līmenī. Abus šos līmen,us nevar skatīt atrauti vienu no otra. 
Fromms atzīst, ka sarežğỉjumus patiesības izpratnē rada tas, ka gan sabiedrība kopumā, gan atsevišķs cilvēks ir pakḷauti dažādām idejām, kas tiek uztvertas kā neapstrīdamas patiesības. Tās darbojas kā dzīves orientāciju model̦i. Ja šie model̦i ir dominējoši, tad reti kad tie paši atklājas, skatoties no iekšpuses, jo tie ieņem vienīgās un absolūtās pozīcijas vietu. Tādā veidā šie modeḷi nosaka vai vismaz būtiski ietekmē to, kā cilvēki raugās uz pasauli. Tāpēc patiesība var būt ne tikai izziṇas rezultāts, bet šādā nozīmē arī - izziñas priekšnosacījums, dzīves orientāciju modelis. Šis apsvērums ir būtiska nianse atšķirībā starp Fromma idejām un pragmatismu tā šaurā izteiksmē. Proti, pragmatisms orientējas uz darbību un rezultātu. Savukārt Fromms atzīst ne tikai patiesības rezultātus, bet vērš uzmanību arī uz patiesības darba sākumu. Viņš atzīst, ka patiesība kalpo arī par rīcības motīvu. Tādā veidā Fromma mācībā par optimālo patiesību piezogas absolūtās patiesības elements, proti, patiesība diktē savus noteikumus, pirms tā vēl ir noskaidrota.

$\bar{E}$. Fromms raksta, ka, lai iegūtu objektīvu jeb patiesu patiesību, vajadzīga ne tikai adekvāta attieksme pret ārpasauli, bet arī pret sevi. Pētniekam jeb izzinošajam subjektam jābūt skaidrībā par apstākḷiem un nosacījumiem, kuros viņš pastāv. ${ }^{14}$ Šie apstākḷ li būtiski nosaka arī attiecības ar objektu un var to ietekmēt. Tātad patiesībai vajadzīgas divpusējas attiecības un divpusēja noskaidrošana. Jāizgaismo ir ne tikai objekts, bet arī pats subjekts. Fromms šeit norāda uz būtisku apsvērumu: būtu aplami noraidīt ieinteresētību kā svarīgu faktoru zināšanu ieguvē. Taču te jāsaprot, ka pastāv dažādas iespējas. Ieinteresētība var kalpot par nekontrolētu spēku, kas noved pie izziņas sagrozī̌̌anas, fantāzijām un aizspriedumainības. Savukārt tāda ieinteresētība, kas darbojas kā motivējošs spēks, jāatzīst par dabisku izzinošā subjekta aktivitātes elementu.

Fromms norāda uz būtisku atšķirību: objektivitāte nenozīmē atsvešinātību. Gluži otrādi, tā nozīmē respektēšanu, tā ir „spēja neizkropḷot un nefalsificēt lietas, personas un pašam sevi". ${ }^{15}$ Tas, kas sagroza patiesību, ir nevis interese pati par sevi, bet gan noteikta veida attiecibas starp subjektu un objektu. Viňš raksta: „Objektivitāte prasa ne tikai redzēt objektu tādu, kāds tas ir, bet redzēt arī pašam sevi, kāds es patiešām esmu, t.i., jābūt zinošam par partikulārajām konstelācijām, kādās pats atrodas kā novērotājs attiecībā pret novērojumu objektu." ${ }^{16}$ Viņš secina, ka tādas pēdējās patiesības meklējumi, kurus nevada pašas personas motīvi un vēlmes, kḷūst par sterilu un bezjēdzīgu 
nodarbi. Šāds secinājums ir pilnībā saprotams no dzịlu psihologijas perspektīvas, bet varētu šķist apšaubāms no filosofijas pozīcijas. Taču te jāṇem vērā, ka Fromma tiešais uzdevums nav filosofisku problēmu risināšana.

Fromms izdara vēl kādu secinājumu. Proti, viņš raksta, ka zinātnes vēsturi nevar aplūkot kā tādu, kas būtu vadījusies tikai no Absolūta meklējumiem. Absolūts ir bijis vien viena šķautne no plašāka un sarežgīitāka patiesības meklēšanas cel̦a. Viņš pat apgalvo, ka visa zinātnes vēsture ir neprecīzu apgalvojumu vēsture. Taču katrs jauns atklājums ir veco kḷūdu pārformulěšana un izlabošana. Tādā ziṇā patiesība ir dinamiska. Tā nav jāuzskata par kādu galējo un pēdējo punktu, līdz kuram jācenšas sniegties, bet drīzāk jāuzlūko kā orientieris, kas, Fromma vārdiem runājot, ietver optimālo patiesību, ko iespējams gūt noteiktā vēstures mirklī.

E. Fromma pārdomas par absolūto un optimālo patiesību izgaismo būtiskas filosofijas problēmas. Taču viņa pienesums ir nevis teorētiski spriedumi par pašas patiesības iedabu, bet gan par cilvēka lomu patiesỉbā. Fromma pārdomas nevar aplūkot kā iespējamu vai neiespējamu risinājumu metafizisku sarežğíjumu pārdomāšanā. Drīzāk viņa loma ir jāmeklē citā virzienā. Fromms vērš uzmanību uz individuāla cilvēka iesaistītību dzìves pasaulē, kurā cilvēkam jāsastopas ar savām īpatnajām, personiskajām problēmām.

Fromms raksta par cilvēka vietu un uzdevumu: „Šai problēmai ir tikai viens risinājums: nostāties aci pret aci ar patiesību, atzìt savu fundamentālo vientulību un vienatni vienaldzīga universa priekšā, atzìt, ka nepastāv pārcilvēciski spēki, kas varētu atrisināt paša problēmas. Cilvēkam jāpieņem atbildība pašam par sevi un fakts, ka tikai, lietojot paša spēkus, izdosies piešķirt dzīvei jēgu." ${ }^{17}$ Protams, tas neatcel, tos jautājumus, kurus uzdod absolūtas patiesības meklējumu cel̦š.

Tomēr tāds arī nav uzdevums. Ē. Fromma pienesums jāaplūko citā kontekstā, proti, praktiskās vai reālās dzīves ikdienas jautājumu risināšanā. Šādā perspektīvā var secināt, ka viṇa idejas ir aktuālas tad, kad problēmām ir vajadzīgs nevis teorētisks skaidrojums, bet praktisks risinājums. Fromma pragmatiski ievirzìtā optimālā patiesība ir tieši tas, ko izteic tās nosaukums optimāla. Tas nenozīmē, ka tā ir vienīgā, labākā vai pareizākā, bet gan to, ka šādai patiesībai piemīt lietojums. 


\section{Vēres}

I Precizitātes labad gan jāpiebilst, ka Dāles un Raudives teiktais ir tapis izolēti, proti, tā nav ierobežota viņu abu diskusija. Plašāk par patiesības jēdziena raksturojumu pirmskara Latvijā (ne tikai par Dāles un Raudives uzskatiem) skat.: Kūlis M. Patiesības izpratne latviešu pirmskara kultūras filosofijā. Modernitātes veidošanās Latvijā filosofiskajā un ideju vēstures skatījumā: personības un virzieni. Rīga: FSI, 2012, 134.-144. lpp.

2 Dāle P. Uz šaubu spilvena. Vērojumi un pārdomas. Rīga: Alfrēda Ūdra apgāds, 1944. (Citēts no: digit. grām.: Jankovskis G̣., Kūlis M., Vērpe K. u.c. (sast.). Latvijas filosofs(e) virtuālais modelis. Rīga: FSI, 2009).

3 Turpat.

4 Raudive K. Par valsisirdību. Dzìves kultūrai. [b.v.]: K. Rasiņa apgāds, 1942. (Citēts no: digit. grām.: Jankovskis G̣., Kūlis M., Vērpe K. u.c. (sast.). Latvijas filosofs(e) - virtuālais modelis. Rïga: FSI, 2009.)

5 Turpat.

6 Fromm E. To Have or to Be. London, New York: Bloomsbury Academics, 2013, p. 84.

7 Raudive K. Par valsirdību. Dzìves kultūrai. [b. v.]: K. Rasiņa apgāds, 1942. (Citēts no: digit. grām.: Jankovskis G̦., Kūlis M., Vērpe K. u.c. (sast.). Latvijas filosofs(e) - virtuālais modelis. Riga: FSI, 2009.)

8 Nietzsche F. Über Wahrheit und Lüge im außermoralischen Sinn. (Citēts no: Nīée F. Melošanas māksla. Pārdomas un aforismi. / Sast. I. Šuvajevs. Rīga: Zvaigzne ABC, 2009, 7. lpp.)

9 Raudive K. Par val̦sirdību. Dzīves kultūrai. [b.v.]: K. Rasiṇa apgāds, I942. (Citēts no: digit. grām.: Jankovskis G̦., Kūlis M., Vērpe K. u.c. (sast.). Latvijas filosofs(e) - virtuālais modelis. Riga: FSI, 2009.)

Io Nietzsche F. Über Wabrheit und Lüge im außermoralischen Sinn. (Citēts no: Nī̌e F. Melošanas māksla. Pārdomas un aforismi. / Sast. I. Šuvajevs. Rīga: Zvaigzne ABC, 2009, 27.lpp.)

II Turpat.

I2 Fromm E. Man for Himself. London: Routledge, 2002, p. $237 \mathrm{ff}$.

I3 Starp pragmatisma teorijas klasiskajiem tekstiem var minēt, piemēram: Peirce C. S. How to Make Our Ideas Clear; James W. Pragmatism's Conception of Truth; Putnam H. Two Philosophical Perspectives; Rorty R. Objectivity, Relativism and Truth.

Pašu pragmatisma teoriju var iedalīt divos veidos: pirmais, konsensus tips, ko saista ar Č. S. Pīrsa (C. S. Peirce) vārdu: Kaut kas ir patiess, ja to praksē apstiprina visi, kam ir pietiekama un atbilstoša pieredze. Savukārt otrs veids ir instrumentālisma teorija (V. Džeimss (W. James), J. Djūijs (J. Dewey), F. C. S. Šillers (F. C. S. Schiller)). Šajā pieejā izteikumu atzīst par patiesu tikai tad, ja rīcỉba, kas izriet no izteikumā ieslēptiem uzskatiem, ilgtermiṇā noved pie kādiem ieguvumiem.

I4 Fromm E. Man for Himself. London: Routledge, 2002, p. I04.

Is Ibid.

16 Ibid.

17 Ibid., pp. 44-45. 


\section{Anna Kande}

\section{Brīvība stoa filosofijas determinismā}

IEVADS

Viscaur cilvēces vēsturei brīvība ir viens no augstākajiem cilvēka mērķiem. Tā ir priekšnoteikums atbildīgai, jēgpilnai un apzinātai dzìvei. Tā ir katra cilvēka laimes nosacījums, jo, tikai būdams brīvs, cilvēks var attīstīties, veidoties un apzināties sevi kā individualitāti. Taču līdz ar šiem apgalvojumiem parādās arī problēmjautājumu un paradoksu virkne. Jo ko gan nozìmé brīvība? Vai tas, ka esam paklauti noteiktai valsts, reliğijas, dabas un citu saistošu likumu kārtībai, paredz, ka nevaram istenot iepriekš „nosaukto” dzìvi? Vai šādu likumu neesamība bütu attiecīgas dzìves pamats un garants? Šo jautājumu virkni varētu turpināt bezgalīgi, uzdodot tos kā praktiskā, tā teorētiskā plaknē.

Tādējādi nepārsteidz, ka brīvības problemātika dažādos kontekstos, no antīkā laikmeta līdz pat mūsdienām, ne mirkli nav zaudējusi savu aktualitāti. Un svarīgi ir akcentēt, ka šo aktualitāti nosaka ne vien tās eksistenciālā nozīme cilvēciskajā noteiksmē, bet arī tās problemātiskums - šķērṣ̌li un ierobežojumi, ko cilvēka brīvības ${ }^{1}$ sastop visā cilvēces vēsturē, un visbeidzot cilvēka attiecíbas ar to.

Apcerējuma pamatjautājums ir - brīvības iespējamība determinisma nosacījumos un kas ir šīs brīvības pamats. Lai atklātu brīvības nozīmi, rakstā tiks aplūkotas brīivibas attiecības ar tādiem saistītiem jēdzieniem kā izvēle, griba, pašvara. Tiks meklēta to saturiskā nozīme un loma brīvības īstenojumā. Jautājums tiks skatīts dzīvesmākslas filosofijas perspektīvā, izmantojot 
protreptiska² rakstura tekstus. Tiks aplūkota brīvība tās iespējamības un ierobežojumu problemātikā, akcentējot divus aspektus - cilvēka brīvību ārējo ierobežojumu jautājumu un iekšējo ierobežojumu jautājumu. Brīvības ārējo ierobežojumu nošķ̄īumu un noteiksmi veiksmīgi ir izveidojuši jau stoa filosofijas pārstāvji, ${ }^{3}$ savukārt, kas attiecas uz brīvības iekšējiem ierobežojumiem, stoa filosofu sniegumu aktuāli un nozīmīgi papildina psihoanalītiḳis Ērihs Fromms, kura pētījumos brīvība ir ieņēmusi vienu no centrālajām lomām un kura meklējumos brīvības un cilvēka attiecības iegūst antīkajā filosofijā neesošu aspektu.

Dzīvesmākslas filosofija, lai arī kāds būtu tās saturiskais motīvs, sakņojas izvēlē, ko veic pats dzīvesmākslas subjekts. ${ }^{4}$ Mēs varam to nosaukt par varas atgūšanas projektu, taču nevis kādas abstraktas vai uz citu pakḷaušanu balstītas varas, bet gan varas pār svarīgāko - sevi, tātad pašvaras atgūšana. Tāpēc runa ir par izvēli par labu pašvaras atgūšanai. Tādējādi par pašvaras atgūšanas nozīmīgu faktoru kḷūst fundamentālā izvēle, kuras iespējamības pamats un nodrošinājums ir brīvā griba. Brīvā griba ir dzīvesmākslas filosofijā rodamās brīvības neatn,emams atribūts. Un lai gan Stoa filosofijā brīvā griba tiešā veidā neparādās, fundamentālās izvēles iespējamības pamatošanai tiek izmantots prohairesis, kas ir saistāms ar brīvās gribas jēdzienu. Fundamentālā izvēle nozīmē apzinātu, iesaistītu, mērķtiecīgu izvēli par labu noteiktam priekšstatam, vērtībai, prioritātei, rīcībai un citiem pašnoteiksmes un pašrealizācijas veidiem jeb dzīvesveidam, kura rīcības, lēmumi, priekšstati tiek veidoti atbilstīgi attiecīgajai izvēlei. Tā ir izvēle attiecībā uz savas brīvības un izvēles iespējas izmantošanu, tātad - aktualizēěanu vai neizmantošanu. Dzìvesmākslas filosofijas kontekstā tā ir eksistenciāla ${ }^{5}$ dzīves izvēle. Brīiviba ir tas apstāklis, kas ḷauj īstenot brīvo gribu, izdarīt un īstenot izvēli, tādējādi ḳ̣ūstot par neatņemamu dzīvesmākslas filosofijas daļu.

Dzìvesmākslas filosofijā brīvības nojēgums ir jo cieši saistīts ar atbildību un pienākumu. Taču kā viens, tā otrs ir nevis brīvības realizācijas šķ̣ēršli, bet gan tās realizācijai nepieciešama komponente.

\section{BRĪVİBAS NOŠĶĪRUMS STOA DETERMINISMA NOSACĪJUMOS}

Brīvības iespējamības un ierobežotỉbas problemātiku tātad jo skaidri ir saskatījusi jau stoa filosofija, kuras atstātais mantojums uzskatāmi parāda 
cilvēka lomu, tā spējas un iespējas. Stoa filosofija ir izvēles un brīvības filosofija. „Kā atgūt sevi? Kā neḷaut sevi iekarot? Kā saglabāt pašvaru, kas nav nekas cits kā vara būt pašam? Iespējams, ka atbildes uz šiem jautājumiem vislabāk meklēt ar stoiķ̣u palīdzību. Stoa filosofi ir kosmosa karavīri. Stoiķis ne pavisam nav cilvēks, kas vīrišk,īgi un pacietīgi iztur dažādas likstas, pacieš tās. Stoikisis ir karotājs, viņš zina, kā neḷaut sevi okupēt, viṇš prot dzīves jūklī saglabāt sevi un būt pats,"6 sarunās par filosofiju raksta I. Šuvajevs. Un šeit svarīgi ir atzīmēt stoa filosofijai un antīkajai filosofijai kopumā raksturīgo veidojošo dabu, kas paredz formēšanas prioritāti pār informēšanu. Kas nozìmē, ka stoa filosofija ne vien parāda, bet ir arī pamudinoša un, mūsdienīgi sakot, motivējoša, rosinoša un pat risinoša jeb uz noteiktu esamības veidu virzoša filosofija. „Filosofija māca nevis runāt, bet rïkoties," ${ }^{7}$ raksta Seneka. Tas ir svarīgs aspekts darba mērķa īstenošanai.

Cilvēks ir sociāla būtne, ${ }^{8}$ kas stoa filosofijas aprisēs paredz cilvēka dabas determinētību. Cilvēks tātad ir iesaistīts kā sociālajos, tā dabas procesos un norisēs. Pirmkārt, cilvēks, dzīvojot sabiedrībā, noteiktā politiskajā režīmā, ekonomiskajā situācijā, kultūrvēsturiskajā realitātē (un šo uzskaitījumu varētu turpināt bezgalīgi), neizbēgami saskaras ar dažādu savu brīvību ierobežojumiem. Eiropa pēdējā gadsimta laikā ir piedzīvojusi tirānus, karus, badu un liegumus, kas skar pat vitālos dzīves aspektus. Cilvēki ir alkuši pēc miera un brīvības un ... ir tos sasnieguši. Taču iepriekšējo nemieru un nebrīvju vietā ir nākuši citi nemieri un nebrīves, lai arī ar „cilvēè̄gākeu” seju.

Un, otrkārt, būdams iesaistīts šajos procesos, cilvēks kā dabas (ķermeniska) būtne ir neizbēgami klātesošs arī dabas procesos, kas paredz iesaistīitibu laika ritējumā, dažādos fiziskos un ķīmiskos procesos un citās ar paša cilvēka gribu vien dal̦ēji saistītos vai nesaistītos procesos. ${ }^{9}$ Tie ir vien daži piemēri, kas atspogulo cilvēka ārējo iespēju nosacìto un laicīgo dabu, kas tāda ir bijusi viscaur cilvēces vēsturei. Taču arī šajā „nolemtajā" cilvēka pozīcijā tam ir lemta brīvība. Ë. Fromms darbā „Bēgšana no brīuības” uzsver, ka brīvìba ir cilvēka dabas neatnemams atribūts. ${ }^{10}$

Precizitātes dēḷ darbā ir jāievieš nozīmīgs nošķīrums - ārējās brīvības un iekšèjā brīvība. ${ }^{11}$ Ārējās brīvības, par ko jau runāts, attiecas uz iespēju izvēlēties rīcību, nesastopot ārējus ierobežojumus. Ārējie ierobežojumi ir jāsaprot kā no paša cilvēka neatkarīgi apstākḷi, kas rada šķēršlus izvēles veikšanai un izvēlētās rīcības īstenošanai. Tāpēc brīvība - par ko filosofija 
var runāt - ir cilvēka iekšêjā brīvība. Iekšèjā brīvība ir spēja patstāvīgi domāt, pien,emt lēmumus, apzināties sevi kā domājošu būtni un savas darbỉbas subjektu. Iekšèjās brīvības vienīgais kungs un pavēlnieks ir pats cilvēks un nevienam citam nav varas ierobežot to. Tāpēc iekšèjā brīvība pastāv neatkarīgi no ārējām brīvībām. Runa tātad ir tieši par pašvaru jeb varu, kas nav atrodama ārējā plaknē.

Šis nošķ̄irums parāda brīivibas un determinisma attiecības, par ko runāja Stoa filosofi: „Ved likten's klausīgos, velk spītīgos." ${ }^{2}$ Stoa filosofija - kā uz mērķi vērsta filosofija - šo brīvības veidu nošķīruma un brīvības iespējamības pamatošanai izstrādā stratēgiju. Tā meklē cilvēka brīvības iespējamību nepieciešamo un nenovēršamo logosa likumsakarību pasaulē. Epiktēta skatījumā vienīgā cilvēkam pieejamā brīvība ir tikumīgas dzīves izvēles brīvība. Tā ir saskaņa pašam ar sevi un kosmosa ${ }^{13}$ logisko izkārtojumu, kuru cilvēks var sasniegt, tikai veidojot pareizus priekšstatus par lietu patieso dabu un pareizi šos priekšstatus izmantojot. H. Bēringers tam sniedz vienkāršu, bet kodolīgu stoa filosofijā sakņojošos skaidrojumu - viņš saka, ka būt laimīgam īstenībā nozīmē mācēt izturēt nelaimes un spēt tajās dzīvot. ${ }^{14}$ Lai arī stoa filosofijā cilvēks nekādi nespēj ietekmēt pasaules cēlon,sakarības un tādējādi arī savu likteni, Epiktēta filosofijā iepriekš nepieredzēti nozīmīgu lomu ien,em izvēles brīvība. ${ }^{15}$ Tas nozìmē, ka tikums nav determinēts, tas ir brīvs. Tikuma ieviešana, izkopšana un attīstīšana ir katra cilvēka brīva izvēle. Tātad arī laime ir katra cilvēka brīva izvēle. Bet izvēles īstenošanai cilvēkam ir jāaudzina sevi un jāvingrinās „, tikumībā”. Lai tas būtu iespējams, cilvēkam ir jāpazīst sevi, bet iepazīt sevi cilvēks var, tikai iepazīstot kosmosa log̣isko izkārtojumu, jo cilvēks ir neizbēgama šĩ izkārtojuma daḷa. Tādējādi Stoa filosofijā pasaules determinisms no totāla brīvību ierobežojuma kḷūst par zināmu brīvības atgūšanas projekta daļu.

Taču, lai saprastu, ko nozīmē šis es, pār kuru ir atgūstama vara un kurš ir jāiepazīst, vēl brīdi pakavēsimies pie Epiktēta, atsaucot atmiṇā vin,a „lietu” iedalījumu - lietās, kas ir paša varā un no paša atkarīgas, un lietās, kas tātad nav no paša atkarīgas. No paša neatkarīgo lietu uzskaitījumā nonāk amati, īpašumi, vara pār citiem, ietekme, citu viedokḷi un pat paša ķermenis, savukārt otrajā jeb no paša atkarīgo lietu grupā ir uzskaitāmi paša priekšstati, tieksmes, jūtas, izvēles, novēršanās un rīcības. ${ }^{16}$ Tas skaidri demonstrē stoa filosofijas stratēǵijas pamatus un pārliecỉbu. Saskaņā ar šo parocīgo 
uzskaitījumu ir viegli nosakāma attieksme pret lietām un paša novietojums starp tām. No mums atkarīgo lietu sfērā, saskaņā ar Epiktēta atziņu un kas ir raksturīgi antīkajai filosofijai kopumā, neapstrīdama priekšroka ir dodama tam, kas atbilst tikumīgajam, savukārt no mums neatkarīgo lietu sfērā ir jābūt pietiekami vienaldzīgam, lai nezaudētu savu pašvaru, atdodot to lietām, cilvēkiem un šķietamām vērtībām. Vienaldzība stoiķiem gan nenozīmē pilnīgu vienaldzību, tā ir drīzāk indiference, kurā dažām no indiferentajām lietām ir dodama priekšroka (veselība, labklājība utt.), citām savukārt nav ( slimība, nabadzība, nāve utt.). Saskaṇā ar šo stratēgisko iedalījumu no paša atkarīgās lietas ir atkarīgas no paša neatkarīgi no apstākliem, savukārt no paša neatkarīgās lietas ir ietekmējamas, vērtējamas, iegūstamas vai noraidāmas vien tādā mērā, kādā tas nekaitē būtiskajam - sev. Tas nozīmē, ka nav vērts sapelnīt bagātîbu vai iegūt atpazīstamību, ja tā cena ir sevis (harmonijas ar sevi, miera, drošības sajūtas utt.) zaudēšana. Epiktēts atzīmē, ka putni nebrīvē labāk mirst. ${ }^{17}$ „Cilvēki gan ir dīvaini radījumi, jo nereti nebrīvi uzskata par dzīvi un savā verdzībā gūst baudu." ${ }^{18}$ Epiktēta filosofija ir vērtējama kā vingrinājumu filosofija, pašvaras ievingrināšana.

Taču jau šajos citātos ieskanējās kāds savāds motīvs. Runa ir par minēto $\bar{E}$. Fromma izteikumu, ka brīvība ir katra cilvēka neatņemamais atribūts. Rodas jautājums, ja tas ir ikvienam piederīgs un klātesošs, tad kālab gan tas arī nekalpo vispārējai, universālai atbildei par brīvības iespējamību? Jā, brīvība ir iespējama, ikviens cilvēks ir brīvs, taču situāciju sarežg̀ît tas, ka šī ikvienam piemītoša brīvā izvēle paredz arī pasīvu izvēli šo brīvību neizmantot un pašvaru neaktualizēt jeb pasīvi izvēlēties būt atkarīgam no lietām, kas nav no paša atkarīgas. Tieši tas ir vēl vārdā nenosauktais, iekšējais brīivibas īstenošanas šḳērslis.

\section{VIENĪGĀS BRĪVĪBAS „BIEDS” UN IESPĒJAS}

Tātad, tika noskaidrots, ka vienīgā cilvēkam pieejamā brīvība ir iekšèjā brīvība, kas ietver, uz gribu balstītu, izvēles brīvību, kura spēj nodrošināt cilvēka varu pār sevi jeb pašvavu. Taču kā pārliecinājāmies arī tā ir apdraudēta un tās vienīgais bieds ir pats subjekts jeb vienkārši pats. Stoa filosofijā tiek runāts par kaislībām, bailēm un iekārēm, padošanos, kuras nostata cilvēku tiešā atkarībā no ārējiem apstākḷiem, kas liedz īstenot paša brīvību un padara 
par apstākḷu vergu. Pēc jau iepriekš noskaidrotā - tas ir ceḷš uz nelaimību. Tad jājautā, kāpēc cilvēks izvēlas būt nelaimīgs?

Antīkā filosofija atbildi saskata cilvēka nezināšanā, jo tikai nezinošais rīkosies pretrunā logosam, tātad arī savam paša saprātam. Tātad arī stoa novēršanos no sevis skaidro kā zināšanu trūkuma izpausmi. Šajā gadījumā nezināšana nekādi nav l̦aunprātîba. Cilvēks var rīkoties netaisni pret sevi pašu vai citiem, vienīgi nezinot, ko nozīmē taisnīga rīcība. Brīvības un determinisma kontekstā runāt par, jau iepriekš konstituētās, brīvības nerealizēšanu nozīmē nepievēršanos sev. Šāds nezinošais, pēc stoa domām, par sevi domā kā par ķ̣ermeni, mantas īpašnieku, amata cilvēku, sevi kā garīgu būtni atstājot perifērijā. „Nejēgas pazīme ir tā, ka viņš pastāvīgi nodarbojas ar miesiskām vajadzībām - daudz vingro, daudz ēd, daudz dzer, bieži iet sevis pēc, daudz kopojas. Tas viss jāuzskata par otršķirīgu." ${ }^{19}$ „Nejēga”, pēc Epiktēta atziņas, ir cilvēks, kam nav brīvības un laimes. Un vienīgais iemesls, kāpēc viņam to nav, ir tikai viņš pats. Vinšs nepan,em laimi, kas ir paņemama. Tā vietā viņš nepārtraukti tvarsta iedomātus mērķus un vērtības, kas sagādā vienīgi vilšanos un ciešanas. Nejēga nav jānosoda vai jāpeḷ, jo viņam jau tāpat nav laimes. ${ }^{20}$ „Nejēga” ir „slimnieks”, kurš ir „ārstējams” vien̄̄gi ar ievingrināšanu pašvarā. Filosofiskas ievingrināšanās ceḷa sākumā cilvēkam ir jāuzvedas kā tādam, kas veseḷojas, bet vēl nav vesels. Tāpēc viņam ir jāuzmanās no visa, kas varētu sekmēt viņa slimības atgriešanos. ${ }^{21}$ Šajā redzējumā ir saskatāma „vērstība uz”. Taču vai tas ir tik viennozīmīgi? Vai ir viennozīmīga „vērstība uz”? Ē. Fromma darbā „Bēgšana no brīvības” ir redzams arī „vērstības no” motīvs, kā patstāvīgs konstrukts ar fonu, cēloṇiem, parādību un sekām. Un nu runa nav par pasīvu neizvēlēšanos, bet gan par aktīvu izvēli būt pasīvam. Tā ir novēršanās no brīvības par labu brīvībām. Jeb, veiksmīgāk būtu teikt. - tā ir pievēršanās brīvībām, novēršot sevi no brīvības. Tāa ir bēgšanas no brīvības realizācija. Šajā gadījumā Ē. Fromma sniegums veiksmīgi risina problemātiku, kas stoa filosofijā tika atrisināta vien dal̦ēji un šķiet mūsu laikmetam nepietiekama, šo vairīšanos skaidro vienīgi ar nezināšanu.

E. Fromms bēgšanā saskata cilvēcisko vājumu, egoismu un tuvredzību. Brīvība, brīvas izvēles - tā ir atbildība, atbildība par šìm izvēlēm un to sekām. Būdams nebrīvs, cilvēks vienmēr var paraustīt plecus un pateikt: „Tā nebija mana izvēle”, „Man tas bija jādara” utt. Mēs redzam, ka brīvības jautājums 
arī Ē. Fromma filosofijā kḷūst par cilvēka pašattieksmes jautājumu, par paša izvēles jautājumu, taču šīs izvēles struktūra ir daudz sarežğìtāka. Cīṇa par ārējām brīvībām, ar to saistītās veiksmes un neveiksmes kḷūst par veiksmīgu iekšèjās brīvības atgūšanas substitūtu, ḷaujot cilvēkam izvairīties no atbildības un îstenas pašvaras.

Kas nosaka iekšējo brīvību un tās potenciālos ierobežojumus? Gan brīvība, gan arī ierobežojumi sakņojas cilvēka iedabā. Pēc stoa cilvēkam piemīt no dieviem dotā augstā dvēseles forma, kas ir saprašana. Bet ir zināms, ka cilvēkā ir daudz, kas ir pielīdzināms dzīvniekiem. Un tas ir ķermeniskais mūsos. „Somatiskais sarado cilvēku ar dzīvniekiem un pārejošo, bet logoss - ar dievu." ${ }^{22}$ Būtiskākais nošķīrums starp dzīvnieku un cilvēku ir tas, ka cilvēkam ir šì jau pieminētā augstā būtîbas forma, kas ḷauj tam saprast priekšstatus un darboties ar tiem. Dzīvnieki savukārt priekšstatus ir spējīgi tikai lietot. ${ }^{23}$ Viņiem nekādā mērā nav dotas spējas tos saprast. Tātad arī lietot saskaṇā ar saprātu. Cilvēku spēja veidot priekšstatus un attieksmes arī nosaka cilvēka brīvību. Savukārt ķermenis, atbilstoši dzīvnieciskajai pasaulei, ir piesaistīts fizisko, tātad ārējo vajadzību apmierināšanai. Un šĩ ir tā daḷa, kas ne vien ir tieši pakḷauta determinētās pasaules norisēm, bet ir arī tā, kas cīnās par savu vajadzību primaritāti pār iedzilı̄ināšanos paša eksistencē.

Stoiskā izvēle, kā tika noskaidrots, ir izvēle būt saskaṇā ar sevi. Un raksturīgi antīkajai filosofijai - tas ir tikuma izvēles cel̦š. Saskaņa ar sevi ir saprātam nepieciešama īpašỉba. Tāpēc saskaņā ar stoisko izvēli - jebkādi ierobežojumi attiecībā pret tikumīgu un netikumīgu rīcību zaudē savu būtîbu, jo, izdarot pareizu izvēli, nav iespējams rīkoties citādi kā tikai tikumīgi. ${ }^{24}$ Tomēr tā kā tikums ir pakḷauts izvēles brīvībai, tad to var arī neizvēlēties. Cilvēks var atteikties pien,emt likteni un sacelties pret kosmosa kārtỉbu, rìkojoties un domājot pretēji kosmosa, tātad arī savam saprātam un dabai. Taču visuma kārtībā šì izvēle neko nemaina, tā nekādā mērā nepakḷauj likteni. ${ }^{25}$ Tāpēc vienīgās šīs izvēles sekas ir šî cilvēka nelaimība.

Šo cilvēka dabas dualitāti uzsver arī Ė. Fromms: tā vienlaicīgi ir dabā un transcendē to. ${ }^{26}$ Cilvēks ir vienīgā būtne, kas apzinās sevi dzīvojam. Tam piemīt saprāts un iztēle, kas l̦auj apzināties sevi, savu dzīvu un nāvi, savu iesaistīitibu, vientulību un pašattieksmes iespējas. Cilvēks realizē savas fiziskās vajadzības - èd, dzer, gādā par drošību. Taču ar to cilvēka vajadzības nav izsmeltas. „Cilvēks nedzīvo tikai no maizes vien," ${ }^{27}$ saka Ë. Fromms. Te 
ieskanas iemestības motīvs, tās ir spējas raizēties par savu eksistenci. Pievēršanās sev ir celšs, kā risināt šo iemestību, kā piepildīt savu eksistenci.

$\bar{E}$. Fromms runā par cilvēka vietu pasaulē. Viṇu interesē cilvēks kā sociāla un dabas pasaulē iesaistīta būtne. Tāpēc viņa psihoanalīze ir cieši saistīta ar ètiku, padarot to par cilvēka arheolog̣iju, kas l̦auj nonākt līdz cilvēcisko „pamatu” atsegšanai un nodrošina brīvas pašizveides nosacījumus. Cilvēka dzimšanu E. Fromms saista ar garīgās attīstības procesu, tāpēc daudzi nomirst, nemaz vēl īsteni nepiedzimuši. Garīgās attīstības process nozīmē sevis veidošanu, pievēršanos sev. Tā ir brīvība, kas ir dota cilvēkam un tā paredz izvēli, šo brīvību izmantot vai arī bēgt no tās. Tā ir izvēle - pievērsties sev vai vienkārši atbilst šablonam, neiedziḷinoties nedz sevī, nedz arī, jāatzīst, šablonā.

Runājot par mūsdienām kā par tehnologijas laikmetu, Ē. Fromms uzsver atsvešināšanos no cilvēciskās esamības un pievēršanos lietu pasaulei. Priekšplānā iznāk piederēšanas aspekts, būšanai paliekot perifērijā. Pašmīlestību aizstāj egoisms, taču tā nav kāda cita mīlestības forma, pēc Ē. Fromma domām, tā ir nespēja sevi mīlēt. ${ }^{28}$ Egoisms iet roku rokā ar uztraukumu, skaudību, neapmierinātību, tas tiecas iekārot nesasniedzamo un izvairīties no tā, no kā izvairīties nav mūsu spēkos. Mīlestība ir raksturojama ar rūpēm, cieņu, sapratni, atbildību, kamēr egoismā šìs komponentes ir iztrūkstošas. Egoists var „mīlēt” lietas, kas neprasa nedz rūpes, nedz sapratni. Tā ir nekrofîlija, ko Fromms saskata politikā, ekonomikā, dabaszinātnēs, psihologijā un pašā dzīvē. Tikai neliela daḷa spēj pievērsties dzīvajam un pirmāmkārtām sev, kas ir priekšnosacījums attiecībām ar citiem. Lielākā daḷa izvēlas šablonus, tajos individualitāte tiek aizstāta ar pūla individualitāti, cilvēkam vien cenšoties standartizēties. ${ }^{29}$

Tāda ir pasīvā, neradošā eksistence, kurā, kā jau tika minēts, cilvēks tiek vilkts caur dzīvi. Cilvēks ir „zīdainis, kas vienmēr kaut ko gaida un mūžīgi viḷas." ${ }^{30}$ Vilšanās, paša pasivitāte, bailes neiederēties un nespēks ved pie destruktīvās, „vieglās” pašrealizācijas, tāda ir vardarbība un agresivitāte. Tās ātri un bez kādas īpašas piepūles ḷauj sajusties stiprākam, pārākam. Taču vai tas kliedē nedrošību un bailes? Saskaņā ar stoa filosofiju kaitīgu ieradumu praktizēšanu rada vienīgi pieradumu, bet ne apmierinātību.

Atšķirībā no antīkās filosofijas cilvēka, mūsdienu cilvēks, arī Fromma cilvēks zina vai vismaz nojauš, kas būtu pareizā izvēle. Taču šis izvēles veikšana 
tiek atlikta, viņš gatavojas izlemt un īstenot savu izvēli, viņš zina, ko nozīmē pašvaras aktualizēšana un isstenošana, taču atliek to uz jauno gadu, nākamo pirmdienu, rītdienu vai kādu citu potenciālu starta momentu nākotnē. Un tieši šīs zināšanas, kas stoa filosofijā izpaliek, arī ir cilvēka dzīves traǵisma avots. Cilvēks it kā raksta dzīves melnrakstu, pēc kura sekos tīrrakstā nodzīvota, skaista dzīve paša varā. Marks Aurēlijs atgādina: „Atceries, ka ikviens dzīvo tikai tagadnē un šajā brīdī.” ${ }^{11}$ Izvēloties atlikt „to īsto dzīvi” uz nākotni, cilvēks savu dzīvi realizē vien nosacìti, jo nav atbilstoši klātesošs ne tagadnē, ne nākotnē.

Cilvēka rīcībā ir saprāts un iztēle, kas ir instrumenti sevis pārvarēšanai, tie ḷauj pacelties pāri savai pasīvajai eksistencei par labu radošajai brīvībai, kas ir lemta vienīgi cilvēkam. Transcendējot pasīvo un nejaušā rakstura radību, cilvēks var kḷūt par „radītāju”. Radot cilvēks no pasīvā pakḷaušanās līmeña paceḷas brīvības un mērķtiecības līmenī. Tā ir aktivitāte, kas ir vērsta vispirms uz sevis paša radīšanu. Tā ir mīlestỉba uz sevi kā priekšnosacījums mīlestībai uz citiem un kā pretspars destruktīvajam cilvēkā. Mīlestību raksturo došana, tā ir radī̌sana, cilvēkam izejot ārpus skaudības, tieksmes pēc varas, ierobežotỉbas. Tā ir dzìvīguma izpausme, kam piemīt spēks un dzilums. Taču tās nav nejaušas jūtas, mīlestība ir koncentrēšanās un uz sevi vērstā piepūle, par ko runā Stoa. Mīlestỉbā pienākums un atbildības uzṇemšanās kḷūist pašsaprotami, tie pārstāj būt par vairīšanās objektiem. Tas ir savas brīvības realizācijas, aktualizēšanas un uzturēšanas celšs.

\section{PIENĀKUMI - BRĪVĀS IZVĒLES NEPIECIEŠAMĀ SASTĀVDAḶA}

Pašvarā esošā pienākumi ir nekas vairāk kā fizikas un loǵikas ${ }^{32}$ likumsakarības. Tie ir iekḷāvīgi visuma dabas ainā. Ko tas nozīmēe Tas nozīmē vien to, ka pienākums ir būt tas, kas esi. Ja esi cilvēks - esi cilvēks un dari to pēc iespējas labāk, vispirms jau attiecībā pret sevi pašu jeb valdi pār sevi, jo tas ir cilvēka dabas atribūts.

Tādējādi pienākumi nekādā ziņā nav saprotami kā pretstats vai ierobežojums brīvībai, pienākumi ir brīvās izvēles - tikuma nepieciešama un neizbēgama sastāvdaḷa. Stoiḳi skaidro - pamatpienākums ir atbilstība savai dabai - būt tam, kas tu esi, būt cilvēkam, ${ }^{33}$ nosauksim to par fundamentālo pienākumu. „Atceries, ka tu esi aktieris drāmā un tev jātēlo loma, kādu tev 
iedalījis dzejnieks - ja tā maza, tad mazu, ja liela, tad lielu. Ja dzejnieks grib, lai tu tēlo nabaga lomu, tad pielūko, lai arī to tu labi tēlotu; un tāpat jebkuru citu lomu - vai tā klibiķa loma vai valdnieka loma, vai arī vienkāršā cilvēka loma. Tas, lūk, tas ir tavs pienākums - labi notēlot iedoto lomu; izraudzīties tev lomu - tas ir cita ziṇā." ${ }^{34}$ Taču ir svarīgi n,emt vērā, ka runa lielā mērā ir par domāšanas principu, jo, balstoties stoiķ, attieksmē pret indiferento, kas paredz priekšrokas došanu vai novēršanos, var secināt par izvēli jeb zināmu atbildību ne vien par savas lomas izpildi, bet arī pašu lomu. Ar to ir jāsaprot, ka, esot savā varā, tātad esot atbildīgam par sevi un savām rīcībām, vaidojot patstāvīgus priekšstatus, ir arī jārīkojas saskaņā ar tiem un jāatbild par šīs rīcības sekām. Piemēram, izej pie vīra vien apzinoties, ko tas nozīmē un ko nozīmē būt sievai un ja to apzinoties pie vīra izej, tad esi sieva un esi laba sieva.

No fundamentālā pienākuma stoiķiem izriet pārējie, tam pakārtotie pienākumi. A. Makoveḷskis savā darbā „Epiktēta morāle”, balstoties uz Bonhēfera atzin̄ām, piedāvā diezgan striktu pienākumu klasifikāciju. Vinš̌ izšķir: I) sevis pilnveidošanas pienākumus, 2) pienākumus pret dievu un 3) sabiedriskos pienākumus. ${ }^{35} \check{S}_{1}$ klasifikācija palīdz orientēties Epiktēta pienākumu izklāstā, taču tā ir nosacìta, jo Epiktēta filosofijā pienākumi tik lielā mērā pārklājas, ka veido vienu veselumu.

Pienākumu sfēra stoa filosofijā ir plašāka par labā sfēru, jo tā skar arī vienaldzīgo - to, kas nav no paša atkarīgs, un norāda, kam no vienaldzīgā vajadzētu dot priekšroku (preferentās lietas), bet kas ir noraidāms pavisam. Preferentām lietām nepiemīt labuma statuss, tās ir dalāmas trijās grupās: garīgās vērtības (atmin,a, zināšanas, piesardzība, domāšanas veiklums), ķermeņa dotības (dzīvība, sajūtu orgānu normāla funkcionēšana, veselība, tīrība) un ārējie apstākḷi (draudzība, bērnu radīšana, laulība, vecāki, sabiedrības stāvoklis, mērena materiāla nodrošinātība, politika). ${ }^{36}$ Šeit attiecībā uz preferentajām lietām, iespējams, daudzi jautātu, kāpēc starp tām nav baudu. Senās stoa pārstāvis Kleants uz šo jautājumu atbild, ka baudas nav saskaṇā ar dabu un saprātīgas dzīves ietvaros nenes nekādu derīgumu. ${ }^{37}$

Pienākumus pret sevi var iedalīt pienākumos pret ķermeni un pienākumos pret dvēseli. Pienākumi pret dvēseli ieņem neatṇemamu un centrālu vietu ne vien stoa, bet lielākajā dạ̄ā dzīvesmākslas filosofijas virzienu. Šo pienākumu pamatā ir rūpēšanās par to, kas ir paša. Pienākumi pret dvēseli ietver skeptisku attieksmi un visa apsvēršanu, pareizu un izprastu priekšstatu 
lietošanu. Un tas prasa pilnīgu uzticību visuma kārtībai, apmierinātību ar to, kas notiek, spēju būt pāri laiciskajam un nosacìtajam, atbrīvošanos no afektiem, kas stāv ceḷā cilvēka gara brīvībai. Tātad, ja tu esi cilvēks - saprātīgs dzīvnieks, tad arī rīkojies attiecīgi, tas ir saskan,ā ar saprātu, priekšstatus ne vien lietojot, bet arī saprotot un izskaidrojot. Tas nozìmē - dari savējo. Uz savējā darīšanu attiecas arī sabiedriskie pienākumi, jo tas saistās arī ar palīdzēšanu un laba darīšanu.

Jau tika noskaidrots, ka būtu aplami sacìt, ka stoa filosofija aicina nerūpēties par ķermeni, ğimeni vai sabiedrisko stāvokli, vienkārši par dvēseli tā aicina rūpēties vairāk. No pienākumiem pret sevi izriet pienākumi pret sabiedrību, jo piepildīt savu esamību cilvēks var, tikai kalpojot sabiedrïbai, ${ }^{38}$ pārfrāzējot - esi sabiedrības dạ̦a un kā tāda arī rīkojies.

Sabiedrībā tāpat kā visās citās jomās cilvēkam vienmēr ir jāatceras sava daba un jāatbilst tai, tas nozīmē - ja esi dēls, tad arī uzvedies un domā kā dēls, ja brālis, tad neaizmirsti, ka esi brālis, un vienmēr esi šim nosaukumam atbilstošs, ja esi vīrs, tad arī uzvedies kā vīram pieklājas. Tas pats attiecas gan uz politikịi, gan ārstu, gan filosofu, gan uz jebkuru cilvēku, lai kas viņš arī būtu. ${ }^{39} \mathrm{Jo}$, ja tu neesi arhitekts un nevari uzbūvēt skaistas zāles ar kolonnām, neesi ierēdnis un nevari palīdzēt kārtot dokumentus, tomēr vari būt cilvēks, kas prot veidot pareizus priekšstatus un pareizi lietot tos, vari ārstēt cilvēku dvēseles un palīdzēt cilvēkiem kḷūt par labiem, godprātīgiem pilsoṇiem un laimīgiem, brīviem cilvēkiem. ${ }^{40} \mathrm{~T} \bar{a}$ tu darīsi savējo (sev pienācīgo) un palīdzēsi ne tikai šiem cilvēkiem, bet arī visai tēvijai. ${ }^{41}$

Pienākums pret dievu sevī neizbēgami ietver pienākumu pret sevi un sabiedriskos pienākumus. Pildot tos, cilvēks rīkojas saskaņā ar saprātu, tātad saskaņā ar kosmosu un dievu. Daḷa cilvēka - dvēsele - ir radniecīga dievam, tāpēc cilvēkam savā rīcībā un attieksmē ir jābūt atbilstošam tai. Cilvēkam vienmēr jāatceras, ka Zevs ir dievu un cilvēku tēvs un viņš virza pasauli labi un pareizi, savukārt mums labprāt un ar pārliecību jāseko viņa lēmumiem. ${ }^{42}$ Tieši viņš devis cilvēkam spēju rīkoties ar to, kas ir paša varā. ${ }^{43}$ Rỉkoties ar paša saprātu, tāpēc, darot to pareizi, tu nekad dieviem neko nepārmetīsi un nevainosi tos notiekošajā. ${ }^{44}$

Šàdu pienākumu klasifikāciju un to attiecību ar brīvību atrodam stoa filosofijā, tās pārstāvja Epiktēta darbos (Arriana pierakstos). Tas skaidri parāda ne vien pienākumu un atbildības nepieciešamo klātesamību ikvienas 
brīvības realizācijā, bet arī to „labvēlīgo dabu” jeb to, ka šādā filosofijas griezumā atbildība un pienākumi ir nevis brīvības realizācijas nepatīkamā „blakne”, bet gan zināmā mērā pati brīvība vai tās daḷa. Tas nozīmē, ka noteiktu izvēli no mainīgu vēlmju šķituma jeb iegribām atšķir tieši atbildības sajūta par izdarīto izvēli un tās realizācijas pienākums.

Lìdzīgi arī Ẽ. Fromma pašizveides „projektā” atbildība un pienākums izgaismojas nevis kā smaga nasta, bet gan kā tîkama un pašsaprotama izvēles komponente, kas, jāatzīmē, par tādu kḷūst vien brīvības un radošuma realizācijā, ārpus tā esot kā potencilais bieds un iegansts.

\section{NOSLĒGUMS}

Cilvēks ir dzīva mirstīga būtne, kuru ierobežo pasaules norises un notikumi, uz kuriem cilvēks nespēj vai tikai daḷēji spēj iedarboties. Tā ir cilvēka nolemtība - dzīvot saskaṇā ar sabiedrības un pasaules norisēm. Taču cilvēka rīcībā ir prāts, kas paver tam cel̦u uz sevi. Tā arī ir vienīgā un totālā cilvēka brīvība - radošā brīvība, par ko savos darbos runā E. Fromms un kas iegūst centrālo nozīmi vēlīnajā stoa filosofijā. Cilvēka brīvības un laimes iespējamība ir pasaules norišu saprašanā un pieņemšanā, kā to nerimstas norādīt stoik̦i. Meklējot brīvības ārpus sevis, šie meklējumi draud kḷūt par dzīvi ar bezgalīgu skaitu vilšanos. Tādējādi vienīgā cilvēkam pieejamā brīvība ir tā, kas sakṇojas vienīgi sevī pašā un ir atkarīga no sevis. Šīs brīvības neatṇemama komponente ir brīvā griba, kas nodrošina izvēles iespējas.

Vienīgā cīṇa, kas ir cīṇas vērta, ir cīṇa pašam ar sevi. Šai brīvībai nav ārējo šķēeršlu, tā ir izvēles brīvība. Taču tā nav un nevar būt kāda vienreizēja izvēle, tā ir pastāvīgi aktualizējama piepūle apzinātā dzīves vedumā, kas, balstoties uz brīvību, paredz atbildību pašam par sevi. Kā trāpīgi formulē Ē. Fromms - tas, kas kombinācijā ar cilvēku pasaules piedāvāto „šablonu”, izvēles „vienkāršỉbu” un vispārpien,emtību vairumam liek/l̦auj bēgt no brīvības. Cilvēks pats kḷūst par savas brīvības šḳērsli. Un paradoksālā kārtā arī tā ir izvēle, taču tā ir pasivitātes izvēle. Aktīva eksistence ir piepūle, koncentrēěanās, ko neprasa pasivitāte. Nelaimīgam būt ir vienkāršāk, paradoksālā kārtā pat vieglāk.

Šajā, iespējams, pesimistiskajā ainā stoiķi piedāvā sevis atgūšanas stratēgiju, norādot cilvēkam uz domāšanas un pasaules izpratnes veidu, balstītu 
uz rīcību un vērtību vienīgi attiecībā pret lietām, kas tiešā veidā ir atkarīgas no paša, šādi shēmai kḷūstot par tādu, kurā nav iepējams „zaudēt”. Savukārt Ē. Fromms risinājumu saskata mīlestībā. Nevis kādā nejaušā simpātijā, iekārē vai pieķeršanās gadījumā, bet gan mīlestībā, kas sakn,ojas galvenokārt pašmīlestībā. Tas, kas iepriekš tika aprakstīts kā „grūts” un piepūli prasošs, kḷūst dabisks, lai arī vēl joprojām runa ir par apzinātu piepūli un koncentrēšanos. Mīlestība ir tā „zona”, kurā cilvēkam pietiek „pašaizliedzības” rūpēm par sevi. Mīlestība ir sevis pārvarěšana, transcendēšana par labu augstākai paša eksistencei.

Šajā eksistencē, kas paredz noteiktu sevis pārvarēšanu, par tās iekḷāvīgajām un neatn,emamajām komponentēm kḷūst atbildība un pienākums, iegūstot nepieciešamības un tīkamības raksturu. Šajā redzējumā pazūd atbildības un pienākuma šksietami ierobežojošā nozīme, tiem kḷūstot par paša izvēles īstenojuma pavadoņiem.

\section{Vēres}

I Šeit un turpmāk tekstā, runājot par brīvību, ko ierobežo ārējie šķēeršli, tiks lietota daudzskaiţ̦a forma - brīivibas. Tā kā brīivibas ierobežojumi ir ārkārtīgi dažādi, tad arī pašas brīvības ir dažādas un daudzas. Trāpịgu nošķīrumu mēs redzam J. Berlina darbā: pozitīiā

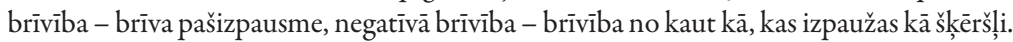
Sk.: Berlins J. Divi brīiibas jēdzieni. Četras esejas par brīvību. Rīga: Sprīdīits, 2000. Plašāk šis jautājums būs iztirzāts raksta nodạ̦ā „Brīivibas noškīirums Stoa determinisma nosacijumos".

2 Ar jēdzienu „protreptisks teksts" ir domāts aicinošs, uzrunājošs, pamudinošs, pievērsošs, rekomendējošs teksts. Šajā gadījumā runa ir par tekstiem, kas piedāvā lasîtājam uz noteikta pasaules redzējuma un pašattieksmes izveides vērstas tehnikas.

3 Apcerējumā stoa filosofiju lielākoties pārstāvēs vēlīnās stoa filosofijas domātāju veikums. Par iemeslu tam ir apstāklis, ka tieši vēlinnajā stoa filosofijā brīvības jautājums iegūst stoa filosofijai raksturīgās brīvības jautājuma izpratnes izstrādātākās aprises.

4 Šmids V. Ievads dzīves mäkslā. Skaistā dzìve? Rīga: Zvaigzne ABC, 2001, 23. lpp.

5 Šajā gadījumā jēdziens , eksistenciāls” reprezentē nevis tiešu saistỉbu ar eksistenciālismu, bet gan aprakstîtās izvēles tiešo saistību ar eksistenci un eksistenciālajām pieredzēm.

6 Šuvajevs I. Filosofija. Sarunas par filosofiju 2. Rīga: Zvaigzne ABC, 2000, 107. lpp.

7 Sen. Epist. CXXXXIV, i.

8 Aristotelis. Nikomaha ètika. Rìga: Zvaigzne, 1985, 36. lpp.

9 Varētu, protams, iebilst, ka mūsdienu zinātne ir sarūpējusi cilvēkam krietni lielākas iespējas ietekmēt savu ķermeni, tā norises un iesaistîtību dabas pasaulē. Taču, lai arī šîs 
iespējas ir nesalīdzināmi plašākas un vispusīgākas nekā tas bija laikā pirms tehnoloğiju un zinātņu straujās attīstības, cilvēka ķermenis tomēr vēl joprojām ir pakḷauts novecošanai, gravitātei, slimībām un citām norisēm, no kurām daudzi, škiet, labprāt izvairītos. Фромм Э. Бегство от свободъь. Москва: Прогресс, г990, с. 479.

II Šajā gadījumā tiešā veidā netiek izmantots J. Berlina minētais noškīīums pozitīvā un negatīvā brīvība nolūkā izvairīties no tam piemītošā politiskā, sociālā apgrūtinājuma, n,emot vērā, ka jēdzieni pozitīvā/negatīvā brīvība ierasti tiek lietoti tieši politiskās un sociālās filosofijas kontekstā.

I2 Sen. Epist. CVII, II.

I3 Stoa filosofijā jēdzieni „kosmoss”, „visums”, „daba”, „logoss” ir cieši saistīti un bieži tiek lietoti kā sinonīmi.

I4 Bēringers H. Kas ir filosofija? Lielvārde: Lielvārds, 1995, 21. lpp. (Turpmāk: Bēringers H. Kas ir filosofija?.)

I5 Epict. Diss. III I, 40; šĩ doma saklausāma M. Polenca darbos, atstāstīts pēc: Столяров А. А. Стоя и стоииизм. Москва: АО Ками груп, 1995, с. 312. (Turpmāk: Столяров A. A. Стоя и стоичизм.)

16 Epict. Ench. I.

17 Epict. Diss. IV I, 26.

I8 Epict. Diss. III 20, 6.

19 Epict. Ench. \$4I.

20 Ibid., $\$ 42$.

2 I Ibid., $\$ 48$.

22 Epict. Diss. I 3,3.

23 Epict. Diss. I 6, 13.

24 Sen. Epist. XX, 5.

25 Saskaṇā ar stoa filosofijas diskursu, kas ir iedalāms fizikā, log̣ikā un ētikā, katra no šīm sadal̦ām kalpo šiem praktiskajiem pašvaras vingrinājumiem. Attiecīgi fizikas mērḳis un nolūks ir atklāt to, kas ir un kas nav paša varā, kas ir pakārtots citām varām un ir saskanīgs ar saprāta nepieciešamību. Fizika paskaidro cilvēka saprāta nepieciešamo saistību un sakṇotību dabas kārtībā. „Fizikas mērogā vērstība uz saskaṇu ar sevi, kas nosaka stoisko izvēli, ir katras dzīvas radības iekšējais pamatlikums kā materiālā realitāte.” Sk.: Цицерон. O пределах... III, 4, 16-22.

26 Fromm E. Interview with Huston Smith: Man's Needs, 2004, p. 2.

27 Fromm E. An Interview with Frederick W. Violence and its alternatives, 2004, p. 2.

28 Fromm E. Selfishness and Self-Love. Psychiatry, 1939, p. 507-523.

29 Fromm E. The Sane society. New York: Rinehart \& Company Inc., 1990, p. 62-63.

30 Fromm E. Ethik und Politik. Weinheim, 1990, S. 22.

3I Marc. Aurel. III, Io.

32 Ar fiziku un log̣iku šeit ir domātas stoa filosofijā domājamā fizika un log̣ika.

33 Hijmans B. L. Askēsis. Notes on Epictetus' Educational System, p. 83.

34 Epict. Ench. \$17.

35 Маковельскій А. Мораль Эпиктета, с. 23. 
36 Čuhina L. Stoicisma filosofiskais mantojums. Domas par antīko filosofiju. / Sastād. Kūle M., Vēbers E. Rīga: Avots, I990, 168. lpp.

37 SVF I 574.

38 Epict. Diss. I 19, I3.

39 Epict. Diss. I 7.-I4.

40 Epict. Ench. \$24.

4I Epiktēts runā tieši par tēviju (patris) un patriotismu, nevis par tautu vai valsti. Sk.: Suvajevs I. Filosofija. Sarunas par filosofiju 2, II4. lpp.

42 Epict. Ench. \$3I.

43 Epict. Diss. I 25, 3; II 16, I 4; III 24, 96-97.

44 Epict. Ench. \$3I. 



\section{Edijs Šauers}

\section{Brīvība kā mīlestības vai mīlestība kā brīvības nosacījums:}

\section{kopīgais un atšksirīgais I. Kanta un Ė. Fromma pārdomās par mīlestību un brīvību}

„Vai maz drīkst mēgeināt salīdzināt domātājus, kas šķiet tik dažādi un nesalīdzināmi esam?" jautā Teodors Celms rakstā, kurā viņš uzrāda Kanta un Dostojevska domu kopīgās un atš̌kirīigās iezīmes. Š Şkiet, līdzīgi varētu jautāt arī par Kanta un Ēriha Fromma salīdzinājumu, kas tiks apskatîts šajā rakstā, - vai tos maz var salīdzināt? Šajā apcerējumāa aplūkotas brīvỉbas un mīlestibas attiecíbas filosofa Imanuela Kanta un psihoanalìtiķa un sociologa Ēriha Fromma uzskatos, parādot abu domātāju kopīgās un atšķirīgās iezīmes šo jēdzienu aplūkojumā. Apcerējums parāda I. Kanta kritisko attieksmi pret morāles, kas balstīta subjekta brīvībā, pamatošanu jūtās, taču rakstā arī norādīts, ka Kanta pozīiija nav vērtējama viennozīmīgi. Savukārt Ė. Fromms pauž uzskatu, ka tieši mīlestībai ir jābūt cilvēku rīcỉbas noteicējai. Rakstā uzrādītas konkrētas tēmas, kas kopīgas I. Kanta un Ē. Fromma uzskatos par brīīibu un mīlestību, t.i. - patstāvība; racionāla ticība; pašizziṇa, kā arī apcerējuma noslēgumā ir norādìti vairāki $\bar{E}$. Fromma pārpratumi par racionālisma ietekmi uz Rietumeiropas garīgo krīzi. 


\section{I. KANTA UN Ē. FROMMA KOPİGĀ IEVIRZE BRĪVĪBAS UN MĪLESTİBAS IZPRATNĒ}

Vispārīgi raksturojot, Kanta filosofijā brīvība tiek nošķirta no dabas. Kants to spilgti demonstrē darbā „Tīrā prāta kritika”, uzrādot prāta trešo antinomiju, kas pamato brīvās kauzalitātes iespējamību iepretim dabas kauzalitātei. ${ }^{3}$ Brīvā kauzalitāte ir iespējama aprioro principu dēl, jo tieši tie nosaka arī pašas kauzalitātes iespējamību. Tā - apriorā sfēra, kas ietver arī transcendentālo brīivibu, - pamato cilvēka brīvību. Šādas - brīvās kauzalitātes - iespējamības pamatojums ir svarīgs Kanta solis brīvības kā morālā likuma nosacỉjuma pamatojumam, proti, lai sniegtu morāli pareizas rīcības pamatojumu. Morālais likums jeb t.s. kategoriālais imperatīvs, kas, Kantam formulējot to vairākās versijās, darbā „Praktiskā prāta kritika” skan šādi: „Rīkojies tā, lai tavas gribas maksima vienmēr vienlaikus varētu noderēt par vispārējas likumdošanas principu." ${ }^{4}$ Morālajam likumam ir jānosaka mūsu rīcība, neatkarīgi no mūsu nosliecēm, to skaitā varam iekḷaut arī mīlestîbu pret otru cilvēku, ja mīlestību ierindojam līdzvērtīgu ar citām jūtām. Minētais likums nav savienojams ar personisko laimi, ja to ņemam kā gribas un tikumības noteicējpamatu, jo, kā norāda Kants, šāds egoistisks princips pilnībā iznīcinātu tikumību. Šajā sakarībā Kants uzsver: „Ja kāds tev visādā ziņā mīḷ̌s un tuvs draugs tavā priekšā sāktu taisnoties par nepatiesi nodotu liecību, teikdams, ka viňš pirmām kārtām aizstāvējis svēto personisko laimes pienākumu, pēc tam uzskaitītu visus labumus, kādus viņš ar to sev guvis [..], tad tu vai nu sāktu smieties viṇam sejā, vai ar riebumu no vin,a novērstos." Rezumējot var teikt, ka Kantam nav pieņemams, ka tikumība tiek pamatota jomā, kas nav prāts, piemēram, balstoties uz kādām personiskām iekārēm kā pašlabums, savtīgums. Kantam raksturīgo nostāju par kategoriskā imperatīva nepiekāpību var labi ilustrēt arī ar viņa līdzīgiem izteikumiem par meliem. Atsaucoties uz vien prātā balstītu prasību rīcības pamatošanai, Kants uzsver nepieciešamību vienmēr teikt patiesību: „Tātad tā ir svēta, nenosacīti pavēloša, nekādu konvenciju neierobežota prāta prasība: visos paskaidrojumos būt patiesam (godīgam).”' Kants aizstāv pozīciju, ka mums ir jāveic noteikti pienākumi, neskatoties uz to, ko mēs iegūstam vai neiegūstam no to sekām. Šàdu rīcỉbu no mums prasa cieņa pret morālo likumu. Taču kategoriālais imperatīvs kḷūtu bezjēèzīgs, ja griba, uz kuru tas attiecas, nebūtu brīva un 
nevarētu brīvi pildīt tā nosacījumus. Tātad ir jāatgriežas pie jau teiktā šîs sadaḷas sākumā - par cilvēka piederību divām pasaulēm. Kà norāda T. Celms, „pieredzes sfairā viss ir iežn,augts nežēelīgos cēlonības žn,augos, un nekādas brīvības te tātad nav, tad brīvība ir iespējama tikai ārpus pieredzes stāvošā pasaulē, ko Kants sauc par intelligiblo. [..] Intelligiblā rakstura balss, pēc Kanta domām, sadzirdama empeiriskā raksturā kā tā saucamā sirdsapziṇa”? Brīvība ir ne tikai morālās rīcības pamatojuma neatṇemama sastāvdaḷa, bet arī visas cilvēka prāta būtības ass.

Plašākā nozīmē Kants iebilst pret to, ka personiskas subjektīvās jūtas varētu kalpot par vispārnozīmīgu tikumības pamatu. Vai kā šo jūtu piemēru var minēt arī mīlestỉbu? Lai gan iepriekš teiktais vedina domāt par pretējo, tomēr Kants mīlestības raksturojumā pietuvojas svarīgām morāles tēmām. Šajā sakarā var minēt vairākus punktus, kas Kanta pozīciju nedara tik striktu mīlestības atraidīšanā. Pirmkārt, Kanta pozīcija piln̄igi nenozīmē otra cilvēka „atcelšanu”, proti, solipsistisku egoismu. Tieši pretēji, Kanta ētikas pamatā ir cilvēka kā mērķa, nevis līdzekḷa vērtības izcelšana. Tiek uzsvērts pienākums pret sevi un otru cilvēku, kas ietver morālajā likumā dibinātu cieņu, t.sk., pašcieņu. Otrkārt, lai gan Kants noraida jūtas kā morāles pamatu, tomēr darbā „Spriestspējas kritika” rodama kāda norāde, kas var likt domāt par pretējo, proti, Kants raksta, ka „skaistais mūs māca neieinteresēti kaut ko mīlēt, pat dabu, bet cildenais - to augstu vērtēt pat pretēji mūsu (jutekliskajām) interesēm”. Šajā citātā teikto var interpretēt kā norādi uz to, ka skaistais un tā „mācītā” mīlestība var rosināt mūs rīkoties tikumiski, ja ar to saprotam pretēji jutekliskajam vērstu, ar prātu pamatotu rīcību. Šeit arī jāpiebilst, ka Kanta gadījumā skaistais ir iespējams, pien,emot „kopizjūtu” (Gemeinsinn), kas ir cilvēka racionalitātē balstīta prasība domāšanas procesā likt sevi otra vietā, kuram arī piemīt tādas pašas dvēseles spējas un augstākās izzinātspējas. Tieši sevis likšana otra vietā, kā arī pašdomāšanas aktualizācija l̦auj skaistā spriedumam pretendēt uz vispārnozīmību. Tas izriet no Kanta izvirzītajām sapratnes maksimām, kas minētas darba „Spriestspējas kritika” 40. paragrāfā „Par gaumi kā sava veida sensus communis”: I) domāt patstāvīgi; 2) domāt, nostatot sevi jebkura cilvēka vietā; 3) vienmēr domāt saskañā ar sevi pašu. ${ }^{9}$ Tas ḷauj mīlestībai savìties ar noteiktu augstāko izzinātspēju darbību, kas piemīt ikvienai racionālai būtnei, tādējādi veidojot kopīgu savstarpējās sapratnes lauku. 
Lai gan morāles pamatošanā Kants runā par morālo likumu (kategoriālais imperatīvs) kā par prāta faktu, tomēr Kants norāda arī uz mīlestības spēku cilvēces laimes veidošanā. „Antropologija pragmatiskā nolūkā” $(1798)^{10}$ Kants vairākkārtīgi piemin mīlestību - gan aicinot jauniešus atteikties no apmierinājuma, t.sk. mīlestības, lai sasniegtu pilnību (\$25), gan to, ka iemīlēties personā, kuru precēt būtu muḷ, kịba, nav cēlonis neprātam, bet gan tā sekas ( $\oint_{53}$ „Dažādas piezīmes”), gan 87. paragrāfā, rakstot par augstāko fizisko labumu, Kants uzsver, ka visspēcīgākās dabas dziṇas ir dzīves mīlestība un dzimuma mīlestība. Tās abas parāda, kā augstākais prāts jeb pasaules pārvaldītājs ved cilvēka dzimumu pie fiziskas labklājības bez cilvēka prāta līdzdarbības. Pirmā mīlestỉba l̦auj saglabāt indivīdu, otrā - dzimtu. Lai arī cilvēce pati sevi nepārtraukti cenšas sagraut, tomēr kultūras veidotās un ar prātu apveltītās būtnes veido tādu laimes stāvokli cilvēcei, no kura vairs nevarēs atkāpties pat gadsimtiem. Savukārt viņa agrīnajā darbā „Vērojumi par skaistā un cildenā jūtām” (1754) mīlestības tēma ir vēl izvērstāka. Jau tad Kants norāda, ka dzimuma mīlestība ir saistāma ar skaisto, bet draudzība - ar cildeno [2:212]. Bet toreiz vēl jaunais Johans Gotfrīds Herders, klausoties Kanta lekcijas par ētiku (1762-1764), piezīmēs min Kanta teikto par mīlestîbas starppersonālo raksturu, norādot, ka Kants esot teicis, ka tas, kurš mīl citus, palielina arī pats savu laimi, lai gan viņš esot norādījis, ka izsaukties „Lai dzīvo mīlestība!” tomēr nevarot. ${ }^{11}$ Mìlestība Kantam nozīmē gan ķermeniskas attiecības starp pretējiem dzimumiem, gan neegoistisku, ar mūsu kognitīvajām spējām saistītu spēku, kuram ir arī morāls un sabiedriskās labklājības raksturs. Un tieši šai otrajai nozīmei ir jābūt noteicošai mīlestības attiecību veidošanā ar morāli.

Pievēršoties Ēriham Frommam, jākonstatē, ka viņš iet pretēju ceḷu nekā Kants. Ė. Fromma gadījumā tieši mīlestība ir nosacījums cilvēku esamībai kopā, to skaitā brīvībai. Atbrīvojies no dabas valgiem, cilvēks tomēr neiegūst apgaismības (Kanta) postulēto patstāvību. Cilvēks drīzāk ir ieguvis nemieru, ko radījis viņa prāts, - nemieru, ko rada domas par viņa galīgumu un atšķirīgumu no citiem. Nemiera cēlonis var būt arī Rietumu cilvēka garīgā krīze, no kuras viņš bēg naudas pelnī̌̌anā un ğimenē, lai gan iekšēji jūtas nedrošs un vientulss. ${ }^{12}$ Kā uzskata $\bar{E}$. Fromms, šo nemieru cilvēks var pārvarēt, vien esot kopā ar citiem cilvēkiem un tādējādi iegūstot vienotību ar citiem. ${ }^{13}$ Fromma gadījumā cilvēku savstarpējās atškirtības radīto tukšumu aizpilda „mīlestība”. 
Viņš norāda, ka mīlestība ir nosacījums mūsu brīvībai, turklāt saistot to ar aktīvu interesi par dzīvi, kas piešķir mīlestībai, tātad arī dzīvei kopumā, estētisku dimensiju. Kanta teiktais par skaistā ietekmi uz cilvēka izvēlēm sasaucas ar Fromma teikto par mīlestību kā spēku, kas pārvar individualitāti un individuālās intereses, kḷūstot par intersubjektivitātes nosacijumu. Tiesa, Fromms uzsver, ka mīlestība nav iespējama bez pašizziņas un pašrūpēm, ko var interpretēt arī kantiski - kā aicinājumu domāt pašam. Tādējādi Kanta „kopizjūtas” nosacījumi, starp kuriem ir arī aicinājums „domāt, nostādot sevi jebkura cita vietā" ${ }^{14}$ kḷūst par Fromma neafektīvās un racionālās , mīlestìbas” pamatu, nezaudējot brīvību pašā brīvībā. Savukārt Fromma mīlestības jēdzienā tiek saglabāts Kanta uzstādījums par autonomiju un pašizziṇu. Taču tie nav vienīgie Kanta un Fromma uzskatu saskarsmes punkti.

\section{I. KANTA UN Ē. FROMMA UZSKATU SASKARSMES TĒMAS}

\section{I. OTRA CILVĒKA OBJEKTIVITĀTE UN ATBRĪVOŠANĀS NO NARCISMA}

Kā jau iepriekš netieši pieteikts, darbā „Spriestspējas kritika” Kants runā par trim sapratnes maksimām, kas paredz: „domāt patstāvīgi; domāt, liekot sevi jebkura cilvēka vietā; vienmēr domāt saskaņā ar sevi pašu”. ${ }^{15}$ Sekošana sapratnes maksimām ḷauj iziet no prāta nepilngadības, kurā cilvēks atrodas pats sava slinkuma dēḷ. Sapratnes maksimas ir noteiktas Kanta sniegtās prasības, kuras ievērojot un arī praktizējot var atbrīvoties no aizspriedumiem, māṇticības un sākt domāt no kopīgā skatpunkta. Sekojot tām, var mainīt savu attieksmi un rīcību pasaulē. Līdzīgi arī Ė. Fromms darbā „Mīlestības māksla”, sadal̦ā par mīlestības praktizēšanu aicina pārvarēt narcismu, kas vairāk vai mazāk piemīt mums katram. Kā norāda Fromms, narcisms izpaužas, kad cilvēks nespēj pien,emt objektīvo realitāti, kā patiesas uztverot tikai paša sajūtas un iedomas. Iznākumā saskarsme ar otru cilvēku kḷūst apgrūtināta vai pat neiespējama. No tā var atbrīvoties, sākot lietot pats savu prātu un esot pazemīgam. ${ }^{16}$ Tādējādi Fromma pārdomas par narcisma pārvarēšanu sasaucas ar Kanta prasību par sapratnes maksimu ievērošanu un nepieciešamību domāt otra vietā - tā ir sevis kā starp cilvēkiem esoša cilvēka konstatācija, kultivējot savstarpējo ciennu, kas ir ne tikai nosacījums morāla likuma realizācijai darbībā, bet arī kā domāšanas regula. 
Šajā punktā ir saskatāma vēl kāda I. Kanta un Ē. Fromma domu līdzība, proti, tā ir sava laikmeta virzỉbas un robežu izvērtěšana jeb kritika. Gan I. Kants - tas spilgti parādās rakstā „Atbilde uz jautājumu: kas ir apgaismība?" ${ }^{17}$, gan E. Fromms pauž kritisku attieksmi pret savu laikmetu. ${ }^{18}$ Kanta gadījumā tas nozīmē saskatīt pavērsienu cilvēces attiecībām pašai ar savu domātspēju un autonomiju, bet Fromma gadījumā - vērtību un cilvēka orientācijas pasaulē atjaunošanu gan caur psihoanalīzi, gan interesi par Austrumu religijāam.

\subsection{RACIONĀLĀ TICĪBA}

$\bar{E}$. Fromms uzsver, ka mīlestība ir ticības akts. Šajā sakarīibā vinšš nošksir racionālo ticību no iracionāāàs ticîbas. Iracionālā ticība balstās padevỉbā otra varai patolog̣iskas psihologiiskās simbiozes attiecībās. Savukārt racionālā ticība „primāri nav ticība kaut kam, bet to raksturo tādas īpašỉbas kā nelokāmība un stingrība, kas piemīt mūsu pārliecībai". ${ }^{19}$ Akls fanātisms tiek nošķirts no zināšanās un pasaules izziņā balstītas pārliecības. Atcerēsimies, ka Kants līdzīgi jau iebilda pret māṇticību un fanātismu, norādot, ka ,jēdziens par Dievu un pat pārliecība par viņa klātesmi var tikt rasti vienīgi prātā, tie var ienākt mūsos tikai no tā un nevis iedvesmā vai kādas vēl lielākas autoritātes pavēstītās ziņās". ${ }^{20}$ Apgaismības aicinājums pārvarēt ticības fanātismu, saglabājot kritisku, prāta robežās balstìtu attieksmi pret Dievu un pasauli, no Kanta darbiem turpinās Fromma pārdomās, kā būtu praktizējama Dieva mīlestība.

\subsection{PAŠIZZIṆA UN JŪTİGUMS PRET SEVI}

Kā zināms, Ē. Fromms par vienu no mīlestības nosacỉjumiem min arī pašmīlu. Tā ir mīlestîba, kas ir vērsta pret sevi kā mīlestibas objektu. N̦emot vērā Fromma izvirzîtās mīlestîbas komponentes, mīlestîbai pret sevi ir jābalstās tajos pašos nosacījumos, kādi ir mīlestībai vispār: sevi ir jāciena, par sevi ir jārūpējas, sevi ir jāizzina, par sevi ir jābūt atbildīgam. Mīlestības praksē Fromms to papildina ar jūtīguma attīstīibu pret sevi. Viņš noraida savu jūtu nepārtrauktu racionalizěšanu, ik uz soḷa uzdodot sev jautājumu, kas ar mani notiek. Drīzāk runa ir par prāta un jūtu savstarpēju saskaņu, kad cilvēks spēj sadzirdēt savu ,iekšējo balsi”". Mūsdienās, kā norāda Ė. Fromms, mūsu iekšějā balss ir vērsta uz tehniku. Cilvēki loti jūtīigi var uztvert motora 
skaņas automašinā, bet palikt kurli paši pret sevi. ${ }^{21}$ Salīdzinot Frommu ar Kantu, varam atkal minēt Kanta slaveno aicinājumu domāt pašam - Sapere aude!, kas ir grūts darbs, tāpēc izdodas tikai retajam. Kā saka Kants: „Ikvienam cilvēkam grūti ir izstrādāt sevi ārā no nepilngadības, kas gandrīz vai kḷuvusi par tā iedabu. [..] ja arī kāds tās [važas, ko rada nepilngadība - E. Š.] nomestu, tad arī pār visšaurāko grāvi viņš spētu izdarīt tikai nedrošu lēcienu, jo nav pieradis pie šādas brīvas kustības. Tāpēc ir tikai daži, kam, veicot sava gara pašpārbaudi, izdevies izrauties no nepilngadības un tomēr uzsākt drošu gaitu." ${ }^{22}$ Tiesa Kants uzsvaru liek tikai uz prātu un tā lietojumu, taču Fromms aicina ar kritisku attieksmi vērsties arī pret jūtām, nepazaudējot jūtu balsi prāta kritikā; to jau iezīmējusi Fromma vērstā kritika pret Rietumu racionālismu. Ko tad izsaka „Sapere aude!"? Tas, ko Fromms dēvē par bēgšanu no brīvības, Kants sauktu par nepilngadību, kura vēl nav spējusi izvēlēties apgaismību. Kants uzsver paša vainu un drosmi būt pašam. Vai tad te nav runa par indivīda (subjekta) brīvību? Par viņa bailēm un bēgšanu no brīvības? Apgaismības idejas piepildījums prasa drosmi atmest ilūzijas, „kaut arī būtu jāiznīkst daudzām cildinātām un iemīḷotām iedomām".23 Nepieciešamību veikt darbu pašam ar sevi uzsver arī Fromms, citējot Z $\mathrm{Z}$. Freida raksturotos psihoanalīzes uzdevumus - „stiprināt Es, padarīt to neatkarīgu no Virs-Es, paplašināt Es vērojumu lauku, lai tas varētu sev piesavināt jaunas Tas daḷas. Kur bija Tas, tur jābūt arī Es. Tas ir kultūras darbs, kas līdzinās purva nosusināšanai." ${ }^{4}$ Fromms uzsver, ka Freids runājis par „cilvēka atbrīvošanu” no neirotiskiem simptomiem. Kants savukārt raksta par domāšanas patstāvību un atbrīvošanos no aizspriedumiem. Ja Kanta gadījumā tas ved pie skaidriem un drošiem spriedumiem, proti, zināšanām, tad Fromma gadījumā runa ir par „labbūtību”. ${ }^{25}$

Jau sākumā vaicāju - vai maz var salīdzināt Kantu un Frommu? Tiesa, arī Fromms pats salīdzina, piemēram, psihoanalīzi un dzenbudismu. Darbā par šo abu garīgo strāvojumu kopīgajām un atškirīịajām iezīmēm, Fromms kritizē racionālismu, to saistot ar pieeju cilvēkam kā lietai. Mūsdienu cilvēks esot nonācis garīgā krīzē, ko raksturo „šizoīda nespēja pārdzīvot emocijas, un tomēr viņš izjūt bailes, depresiju un izmisumu". ${ }^{26}$ Kā norāda Fromms, „cilvēks ir gājis pa racionālisma cel̦u, līdz ir nonācis punktā, kur racionālisms pārtop pilnīgā iracionālismā. Sākot ar Dekartu, cilvēks arvien vairāk nošķ̄īis domu no emocijas. Valda uzskats, ka racionāla ir vienīgi doma, bet emocija 
tiek vērtēta kā savā būtībā iracionāla. Persona jeb Es ir reducēta uz intelektu, kas konstituē patību un kura uzdevums ir pārvaldīt mani tāpat kā pārvaldīt dabu. Intelekta kontroles pār dabu īstenošana un arvien jaunu un jaunu lietu ražošana ir kḷuvusi par dzīves svarīgāko mērḳi. Šajā procesā cilvēks ir sevi pārveidojis par lietu, dzīve ir tapusi pakḷauta īpašumam, „piederēet” ir sācis dominēt pār „būt””" ${ }^{27}$ E. Fromms norāda uz t.s. „kartēziskā duālisma” problēmu, kas paredz striktu divu substanču - res cogitans un res extensanošķīrumu. Šì problēma ir novedusi pie nespējas izjust emocijas, kam ir tālejošākas sociālas sekas - cilvēki nezina, kāpēc viṇi dzīvo, un mērķa - sevi pilnveidot - zaudēšana noved pie pseidoattiecību veidošanās starp cilvēkiem.

$\bar{E}$. Fromma pārmetums par racionālisma tendenci „racionalizēt” - kā psihoanalīzes aprakstītu psihes pretošanās mehānismu aizēno racionālisma centienus formulēt cilvēka cienīgas izziņas un dzīves nosacījumus. Uz šiem nosacījumiem norāda gruzīnu domātājs Merabs Mamardašvili, rakstot par civilizācijas trim principiem - kartēzisko, Kanta un Kafkas. Šķiet, Fromms nepamana vai nevēlas sava projekta ietvaros pamanīt, ka, pirmkārt, Dekarts uzsver noteiktu individuālisma nepieciešamību cilvēkam cienīgas dzīves veidošanā. Dekarta pozīcija „domāju, tātad esmu” ir viens no civilizācijas nosacỉjumiem. Tā vēlāk atsaucas arī Meraba Mamardašvili teiktajā - „pasaulē ir un notiek kāda l,oti vienkārša un nepastarpināti redzama esamība - „es esmu”. Šì esamība, apšaubīdama visu pārējo, ne tikai atklāj, ka viss pasaulē (tostarp arī zināšanas) notiekošais ir atkarīgs no cilvēka paša rīcības, bet arī kalpo par absolūtas drošticamības un acīmredzamības balstu jebkurai domās formulējamai atziṇai”. ${ }^{28}$ Savukārt Kantam, kurš viennozīmīgi ir racionālisma pārstāvis, ir otrs būtisks civilizācijas iespējamības „princips”, kas nosaka, ka „pasaules uzbūvē, kurā iekḷaujas arī cilvēka dzīve, ir īpaši hipotētiski „inteligibli” (prātni, t. i., ar prātu tverami) objekti (dimensijas), kas tai pašā laikā ir arī pieredzē nepastarpināti konstatējami - kaut arī tālāk nesadalāmi - veselumu tēli, kurus varētu uztvert kā attīstības ieceres jeb projektus. [..] Šis princips ir vērtīgs tādēl, ka parāda nosacījumus, kas nepieciešami, lai telpā un laikā galīga būtne, piemēram, cilvēks, spētu jēgturīgi izpildīt empīriskus izziñas, morālas rīcības un vērtējuma aktus, gūt savos meklējumos piepildījumu u. tml." ${ }^{29}$ Lai gan Fromms kritizē racionālismu, tomēr tie ir principi, kurus arī pats Fromms aicina ievērot, tos nosaucot tikai citos vārdos. Šeit ir runa par aicinājumu nodarboties ar pašizziņu kā mīlestības nosacỉjumu. Frommam 
varētu arī pārmest, ka aicinājums atteikties no sevis kā divpatīgas būtnes aplūkojuma diskreditē pašizziņu gan filosofiski refleksīvi, gan arī pašas psihoanalīzes ietvaros. Te var minēt Karenas Hornejas aicinājumu nodarboties ar pašizziņu, kas vienmēr paredz iekšējo dialogu starp diviem - starp iekšējo pacientu un iekšējo analītiķi: „Pašanalīze ir mēgeninājums būt pacientam un analītiķim vienlaicīgi." ${ }^{30}$ Tiesa, šāds skatījums uz divu patîbu būtni sasaucas ar Jesajas Berlina teikto par pozitīvās brīvības radīto 'skābo vīnogu' efektu - norobežotỉba no ārpasaules, kādas pareizās un racionālās patības pārākumā pār zemāko, emocionālāko patību drīzāk raksturīga personai, kas reiz vīlusies un piedzīvojusi spēcīgus negatìvus pārdzīvojumus pasaulē, tāpēc ir atteikusies no emociju pasaules.

Nobeigumā var teikt: Kanta izvirzītie apgaismības nosacījumi mūsdienās piedzīvojuši plašu kritiku un aizrādījumus par pārlieku lielo optimismu cilvēka prāta spējām. 20. gadsimta notikumi ar diviem pasaules kariem bijusi laba augsne šiem iebildumiem. Tai pašā laikā ir tikuši meklēti atpakaļceḷi pie tā, ko, Ē. Fromma vārdiem runājot, var saukt par „pašdisciplīnu”. Kas ir tas, kas ḷauj mums no galējās cīṇas pret autoritārismu tomēr „neiekrist pretējā grāvī”, kādēḷ, kā norāda Ê. Fromms, attīstījies slinkums un t.s. relaksēta dzīves uztvere, kā kompensācija dzīves rutīnai. Ė. Fromms piedāvā risinājumu, kas turpina attīstīt Kanta idejas par racionālas būtnes autonomiju, cien,u un pašizziņu. Tai pašā laikā Fromms arī norāda, ka ierobežojumi mūsu spējai būt pašiem un būt kopā ar citiem var būt sakņoti mūsu sabiedrībā un kultūrā, piemēram, patērētāju kultūrā un kapitālismā, kas cilvēku savstarpējās attiecības pārvērtušas par attiecībām, kurās dominē lietas un preces. Šķiet, $\bar{E}$. Fromms, kritizējot Rietumu kapitālismu, labi apzinās pārmaiṇas cilvēciskajās attiecībās, kuras tas nes līdzi. Tieši tāpēc te noder Kanta padoms, kas, netieši runādams no Fromma darbiem, aicina uz pašdomāšanu un darbu ar sevi, savas un otra cilvēka brīvības un kopīgās dzìves jēgas apzināšanai. ${ }^{31}$

\section{Vēres}

I Celms T. Kants un Dostojevskis. Celms T. Tagadnes problèmas. Rìga: Valtera un Rapas akc. sab. izdevniecība, 1935, 170. lpp.

2 Apcerējuma pamatā ir referāts, kas nolasīts Ē. Frommam veltīitā konferencē „Brìvība un brìvibas: iespējas un draudi" 2013 . gada II. maijā. 
3 Kants I. Tìrā prāta kritika. / Tulkojis R. Kūlis. Rīga: Zinātne, 201I, 282.-287. lpp.

4 Kants I. Praktiskā prāta kritika. / Tulkojis R. Kūlis. Rīga: Zinātne, 2006, ı87. lpp.

5 Turpat, 192. lpp.

6 Kants I. Par iedomātām tiesībām melot aiz cilvēkmīlestības. / Tulkojis I. Šuvajevs. Kentaurs XXI, Nr. 37, 2005, 13.-17. lpp.

7 Celms T. Kants un Dostojevskis. Celms T. Tagadnes problèmas, 174. lpp.

8 Kants I. Spriestspējas kritika. / Tulkojis R. Külis. Rīga: Zvaigzne ABC, 200o, 88. lpp.

9 Kants I. Spriestspējas kritika, I09. lpp.

ıo Citēts pēc: Kant I. Anthropology from a pragmatic point of view. / Transl. and ed. By R.B. Louden, CUP, 2006.

II Herder's notes from Kant's lectures on ethics, 27:53. Citēts pēc: Kant I. Observations on the Feeling of the Beautiful and Sublime and Other Writings, CUP, 2011, pp. 26I-304.

I2 Fromms E. Psihoanalizze un dzenbudisms. / No anglu valodas tulkojusi A. Šuvajeva. Rīga: Zvaigzne ABC, 2002, 30. lpp.

I3 Fromms Ē. Mïlestības mäksla. / Tulkojusi B. Jansone. Rīga: Jumava, 1994, I3. lpp.

I4 Kants I. Spriestspējas kritika, I09. lpp.

I5 Turpat.

I6 Fromms Ē. Mïlestības māksla, I40.-144. lpp.

I7 Kants I. Atbilde uz jautājumu: kas ir apgaismība? Sk.: Kants I. Kas ir apgaismība? / Tulkojis I. Šuvajevs. Rīga: Zvaigzne ABC, 2005, I5.-2I. lpp.

I8 Sk., piemēram, nodaḷu „Mūsdienu garīgā krīze un psihoanalīzes loma” Ē. Fromma darbā Psihoanalize un dzenbudisms, 28.-31. lpp.

i9 Turpat, I44. lpp.

20 Kants I. Ko nozīmē orientēties domāšanā? Kants I. Kas ir apgaismība?, 58. lpp.

2I Fromms Ē. Mïlestības māksla, i38. lpp.

22 Kants I. Atbilde uz jautājumu: kas ir apgaismība?, I6. lpp.

23 Kants I. Tìrā prāta kritika, AXIII, I9. lpp.

24 Fromms E. Psiboanalize un dzenbudisms, 33. lpp.

25 Turpat, 37. lpp.

26 Turpat, 29. lpp.

27 Turpat.

28 Mamardašvili M. Domātprieks. Rīga: Spektrs, 1994, 106. lpp.

29 Turpat, 107. lpp.

30 Horney K. Self-analysis. New York: W.W. Norton \& Company, 1994, p. Ior.

3I Vairāk par Ē. Fromma pieeju kopīgā psihoanalīzes tradīcijā sk.: Šuvajevs I. Dzīlu psiholog̣ija. Rīga: Zvaigzne ABC, 2002, I88.-194. lpp. 
Pielikums 



\section{Ërihs Fromms}

\section{Bēgšana no brīvības"}

BRĪVĪBA UN DEMOKRĀTIJA

I. INDIVIDUALITĀTES ILŪZIJA

Iepriekšèjās nodalāās es centos parādīt, ka mūsdienu industriālajā sistēmā kopumā un tās monopolistiskajā fāzē jo īpaši darbojas noteikti faktori, kas sekmē tādas personības tapšanu, kam raksturīgas bezspēcības, vientulības, trauksmes un nedrošības izjūtas. Aplūkoju arī îpašos apstākḷus Vācijā, kur dal̦a iedzīvotāju gana atsaucīgi pien̦ēma un veicināja tādu ideoloğiju un politisko praksi, ko esmu definējis kā autoritāru.

Taču kā ar mums pašiem? Vai drauds pašmāju demokrātijai ir tikai fašisms otrpus Atlantijas okeānam un „piektā kolonna” amerikāṇu sabiedrībā? Ja tā, tad situācija ir nopietna, bet ne kritiska. Ārējos un iekšējos fašisma draudus jāuztver nopietni, tomēr daudz lielāka kḷūda un nopietnāks apdraudējums būtu ignorēt to pašu parādību mūsu vidē, proti, indivīda nenozìmību un bezspēcibu, kas ir auglīgs pamats fašisma uzplaukumam jebkurā pasaules malā.

Šãds apgalvojums gan ir pretrunā ar vispārpieņemto uzskatu, ka mūsdienu demokrātija ir sasniegusi patiesu individuālismu, jo atbrīvojusi indivīdu no jebkādiem ārējiem ierobežojumiem. Mēs lepojamies, ka nepakḷaujamies ārējai autoritātei un varam brīvi paust savas domas un jūtas; mēs uzskatām

* Fromm E. Escape from Freedom. New York: Farrar and Rinehart, 1941 (New York, 1994, p. 238-297). / Tulkojusi Andžela Šuvajeva. 
par pašsaprotamu, ka šāda brīvība teju automātiski garantē mūsu individualitāti. Tomēr tiesībàm paust savas domas ir nozìme vien tad, ja esam spējīgi domāt paši ; brīvība no ārējas autoritātes ir ilgstošs ieguvums vien tad, ja mūsu iekšējie psiholoğiskie apstākḷi paver iespēju apliecināt savu individualitāti. Vai esam sasnieguši šo mērḳi vai vismaz tuvojamies tam? Šĩ grāmata aplūko cilvēcisko faktoru, tamdēl tās uzdevums ir problēmas kritiska analīze. Dažas iestrādes jau tika veiktas iepriekšejēās nodaḷās. Apspriežot brīvības divus aspektus mūsdienu cilvēka skatījumā, mēs norādījām uz ekonomiskajiem apstākḷiem, kas veicina indivīda izolāciju un bezspēcību mūsu laikmetā. Apspriežot psiholoğiskās sekas, mēs parādījām, ka šāda bezspēcība noved vai nu pie tāda veida bēgšanas, kas raksturīga autoritāra tipa personībai, vai piespiedu konformisma, kura rezultātā izolēts indivīds pārtop automātā, zaudē savu patîbu, vienlaikus uzskatot sevi par brīvu būtni, kas paḳ̣aujas vien̄̄gi paša gribai.

Svarīgi saprast, kā mūsu kultūra sekmē šo konformisma tendenci, pat ja daži spilgti piemēri liecina par pretējo. Spontānu jūtu apspiešana - un patiesas individualitātes attīstība - sākas l, oti agrā vecumā, faktiski līdz ar pirmajiem soḷiem bērna audzināšanā. ${ }^{1}$ Tas nebūt nenozīmē, ka jebkura audzināšana neizbēgami noved pie spontanitātes apspiešanas; tā nenotiek, ja audzināšanas mērķis ir patiesi sekmēt bērna personības izaugsmi, viņa iekšējo neatkarību un individualitāti. Šādai audzināšanai pakḷauts bērns var zināmu laiku saskarties ar noteiktiem ierobežojumiem, bet tie būs tikai līdzeklis viņa tālākās izaugsmes nodrošināšanā. Diemžēl mūsu kultūrā audzināšana pārāk bieži slāpē bērna spontanitāti un aizstāj oriğinālos psihiskos aktus ar ārēji uzspiestām jūtām, domām un vēlmēm. (Atkārtoju: manā skatījumā oriğināla ir nevis tā doma, ko neviens cits agrāk nav domājis, bet gan tā doma, kas dzimst indivīdā kā viņa paša psihiskās darbības rezultāts, proti, kā viņa paša doma.) Lai situāciju ilustrētu, izvēlēsimies, varbūt mazliet patvaḹigi, vienu no agrīnākajiem jūtu apspiešanas piemēriem - naidīguma un nepatikas jūtu apspiešanu. Vispirms atzīmēsim, ka lielākajai daḷai bērnu piemīt zināms naidīgums un dumpīgums, ko raisa konflikti ar apkārtējo pasauli, kas tiecas iegrožot viṇu ekspansivitāti un kuras priekšā viṇiem - kā vājākajai pusei - parasti jāpiekāpjas. Ierobežot šo antagonistisko reakciju ir viens no audzināšanas procesa svarīgiem uzdevumiem. Metodes ir visnotal dažādas, sākot ar draudiem un sodiem, kas biedē bērnu, un beidzot ar maigākiem 
paņēmieniem - piekukulošanu vai „izskaidrošanu”, kas bērnu apmulsina un piespiež atteikties no sava naidīguma. Bērns vispirms atsakās no jūtu ārējās izpausmes un pēcāk - arī no pašām jūtām. Šādi viņš tiek mācīts apspiest savu apziņu par citu ḷaužu naidīgumu un liekulību. Dažkārt tas nenākas viegli, jo bērniem piemīt spēja pamanīt šîs negatīvās īpašỉbas apkārtējos cilvēkos - viṇus nav tik viegli maldināt ar vārdiem kā pieaugušos. Bērna nepatikai pret kādu cilvēku nav „pamatota iemesla”, ja vien par tādu neuzskata viņa spēju sajust naidīgumu vai liekulỉbu, kas izstaro no šìs personas. Drīz vien šì reakcija tiek apslāpēta; nepaiet ilgs laiks, līdz bērns jau sasniedz vidusmēra pieaugušā „briedumu” un zaudē spēju atšķirt krietnu cilvēku no neğẹlı, kamēr tas nepastrādā kaut ko skandalozu.

Turklāt jau audzināšanas procesa sākumposmā bērns tiek mācīts pārdzīvot jūtas, kas nav gluži „viņa paša”; jo īpaši viņam māca mīlēt cilvēkus, būt nekritiski draudzīgam pret apkārtējiem, smaidīt. Ko nespēj panākt audzināšana, to vēlākajā mūža gaitā parasti panāk sabiedrības spiediens. Ja jūs nesmaidāt, tad par jums izsakās kā par ne pārāk ,patîkamu personu”, bet jums taču ir jābūt tīkamam, lai spētu pārdot savus, sacīsim, viesmīḷa, pārdevēja vai ārsta pakalpojumus. Tikai tie, kuri atrodas sociālās piramīdas pašā augšgalā, un tie, kuri atrodas viszemākajā pakāpē, proti, pārdod tik vien kā savu fizisko darbu, var aţ̦auties nebūt diezko „patīkami”. Sirsnība, jautrība un visas pārējās jūtas, kas parasti izpaužas smaidā, pārtop automātiskās reakcijās, ko cilvēks ieslēdz vai izslēdz kā elektrisko lampiņu. ${ }^{2}$

Protams, daudzos gadījumos ḷaudis apzinās, ka viṇu rīcība ir tikai žests, tomēr vēl biežāk cilvēki zaudē šo apziṇu un tādējādi arī spēju atšksirt pseidojūtas no spontānas sirsnības.

Ne tikai naidīgums tiek nepastarpināti apspiests un ne tikai draudzīgums tiek iznīdēts un aizstāts ar uzspiestu viltojumu. Daudzas un dažādas spontānas emocijas tiek apspiestas un aizstātas ar pseidojūtām. Freids vienu šādu apspiešanu, proti, dzimumtieksmes apspiešanu, nolika savas sistēmas centrā. Manuprāt, seksuālās baudas slāpēšana nav vienīgā nozīmīgā spontānu reakciju apspiešana, bet gan tikai viena no daudzām, taču tās nozīmi nekādi nedrīkst nenovērtēt. Tās rezultāti ir acīm redzami gan seksuālas aiztures gadijjumos, gan tajos gadijjumos, kad sekss iemanto piespiedu nepieciešamības raksturu un tiek patērēts kā alkohols vai narkotikas, kam pašām par sevi nav īpašas garšas, bet kas sekmē aizmiršanos. Neskatoties 
uz tām vai citām sekām, seksuālo alku apspiešana - to intensitātes dēl - ne tikai iespaido seksuālo jomu, bet arī vājina cilvēka drosmi paust spontānas emocijas citās dzìves jomās.

Mūsu sabiedrībā emocijas kopumā tiek slāpētas. Lai gan var nešaubīgi apgalvot, ka jebkāda radoša domāšana - tāpat kā jebkura cita radoša darbība - ir nesaraujami saistīta ar jūtu pārdzīvojumu, tomēr par mūsu ideālu ir kḷuvusi domāšana un dzīvošana bez emocijām. „Emocionalitāte” ir kḷuvusi par sinonīmu garīgai neveselībai un nelīdzsvarotībai. Pien,emot šo standartu, indivīds ir sevi ārkārtīgi novājinājis; viņa domāšana ir tapusi noplicināta un piezemēta. Turklāt emocijas, - ņemot vērā, ka tās nav pilnībā likvidējamas, turpina pastāvēt atrautībā no personības intelektuālās puses; rezultāts ir lēta, mākslīga sentimentalitāte, ar ko barojas miljoni pēc jūtām izsalkušu klientu, kino un populāru dziesmu patērētāju.

Vienu aizliegtu emociju es gribētu minēt ìpaši, jo tās apspiešana skar personības dziḷāko būtību; šì emocija ir trağēdijas izjūta. Kā redzējām vienā no iepriekšējām nodal̦ām, nāves un dzīves trağiskās puses apzināšanās - vienalga, skaidra vai miglaina - ir viena no cilvēka pamatīpašībām. Katra kultūra pa savam risina nāves problēmu. Sabiedrībās, kur individuācijas process virzījies uz priekšu gausi, individuālas eksistences gals nav liela problēma, jo individuālas eksistences pārdzīvojums pats par sevi ir mazattīstīts. Nāve vēl netiek uztverta kā kaut kas būtiski atšk,irīgs no dzīves. Kultūras, kurās mēs vērojam individuācijas augstāku attīstības pakāpi, attieksmi pret nāvi veidojušas atbilstoši savai sociālajai un psiholoğiskajai struktūrai. Senie grieķi visu uzmanību veltīja dzīvei un nāvi iztēloja kā ēnainu un padrūmu dzìves turpinājumu. Ēğiptiešu cerības saistījās ar ticību cilvēka - vismaz tāda cilvēka, kura vara dzīves laikā bijusi nesatricināma, - k̦ermeņa neiznīcībai. Jūdi atzina nāves faktu reālistiski un spēja samierināties ar domu par individuālas dzīves bojāju, mierinājumu smel̦ot ticībā laimības un taisnīguma valstībai, pie kuras cilvēce galu galā nonāks šaisaulē. Kristietība nāvi padarīja nereālu un centās mierināt nelaimīgo indivīdu ar solījumiem par pēcnāves dzīvi. Mūsu pašu laikmets vienkārši noliedz nāvi un līdz ar to - arī vienu fundamentālu dzīves aspektu. Tai vietā, lai ḷautu nāves un ciešanu apziṇai kḷūt par vienu no spēcīgākajām dzīves dziṇām, tapt par cilvēciskās solidaritātes pamatu, izvērsties pārdzīvojumā, bez kuras priekam un entuziasmam trūkst intensitātes un dziḷuma, indivīds tiek spiests šo apziṇu slāpēt. Taču - kā jau 
ikvienā apspiešanā - apspiesto elementu slēpšana no acìm vēl nenozīmē to iznīcību. Tādējādi bailes no nāves turpina nelikumīgi dzīvot mūsu vidū. Tās turpina dzīvot, par spīti mūsu centieniem tās noliegt, taču, būdamas apspiestas, tās paliek neauglīgas. Šìs bailes ir viens no cēloṇiem citu jūtu pliekanībai, trauksmainajām alkām pēc dzīves un, gribētos sacīt, pārmēru lielajām naudas summām, ko mūsu tautieši maksā par savām bērēm.

Jūtu noliegšanas procesā modernā psihiatrija spēlē nebūt ne viennozīmīgu lomu. No vienas puses, tās dižākais pārstāvis Freids ir izlauzies caur racionalitātes, cilvēka prāta mērķtiecības fikciju un pavēris taku, kas ḷauj ielūkoties cilvēcisko kaislību dzīlēs. No otras puses, psihiatrija, ko bagātinājuši šie Freida atklājumi, pati kḷuvusi par instrumentu, kas kalpo vispārīgām tendencēm manipulēt ar indivìdu. Daudzi psihiatri, tostarp psihoanalītiķi, ir radījuši priekšstatu par „normālu” personību, kas nekad nav pārmēru skumja, pārmēru dusmīga vai pārmēru savil,ņota. Viṇi lieto tādus apzīmējumus kā, teiksim, „infantils” vai „neirotisks”, lai raksturotu tādas personības tipus vai iezīmes, kas neatbilst vispārpien,emtajam „normāla” indivīda paraugam. Šāda ietekme kaut kādā ziņā ir vēl bīstamāka nekā senākās un vaļsirdīgākās iesauku formas. Tad indivīds vismaz zināja, ka viṇu kritizē noteikta persona vai šì kritika pamatojas noteiktā doktrīnā, un viņš varēja kaut kā aizstāvēties. Bet kurš gan spēj cīnīties pret „zinātni” kā tādu?

Izkroplojumi skar ne tikai jūtas un emocijas, bet vienlīdz lielā mērā arī oriğinālo domāšanu. Jau pašā pirmajā izglītošanas posmā cilvēku attur domāt oriğināli un viņa galvā tiek liktas gatavas domas. To viegli saskatīt attieksmē pret maziem bērniem. Mazul,us caurstrāvo ziņkāre par apkārtni, viņi grib to tvert gan fiziski, gan intelektuāli. Bērns vēlas zināt patiesību, jo tas ir drošākais veids, kā orientēties viņam svešajā un par viņu varenākajā pasaulē. Taču bērna centieni netiek uztverti nopietni un nav pat svarīgi, vai šì nostāja izpaužas kā atklāts noniecinājums vai kā laipna iecietība, kas parasti tiek demonstrēta attieksmē pret vājākajiem (piemēram, bērniem, veciem l̦audīm vai slimniekiem). Šāda attieksme vien jau ir liels kaitējums neatkarīgai domāšanai, bet vēl l̦aunāk kḷūst, ja to pavada nepatiesīgums, kas - bieži netīšā kārtā - raksturo vidusmēra pieaugušā uzvedību attieksmē pret bērnu. Šis nepatiesīgums daḷēji izpaužas tādējādi, ka bērnam tiek rādīta sagrozīta pasaules aina. Tā ir tikpat noderīga kā, teiksim, norādes par dzīvi Arktikā cilvēkam, kurš lūdzis padomu, kā labāk gatavoties ekspedīcijai uz 
Sahāras tuksnesi. Līdzās vispārīgiem pasaules ainas sagrozījumiem pastāv arī daudzi specifiski meli, kuru uzdevums ir apslēpt faktus, ko pieaugušie, dažādu personisku iemeslu dēl, uzskata par bērnu zināšanai nevēlamiem. Bērnam „tas nav jāzina”, un viṇa jautājumiem seko naidīgs vai pieklājīgs atteikums - tas var izpausties gan kā vecāku slikts noskaņojums, kas racionalizējas kā pamatota neapmierinātîba ar bērna uzvedību, gan kā vecāku dzimumattiecību vai strīdu slēpšana.

Šādi sagatavots bērns nonāk skolā vai varbūt koledžā. Es gribētu īsi pieminēt dažas mūsdienu izglìtošanas metodes, kas principā turpina slāpēt oriǵinālo domāšanu. Viena no tām ir stingra prasība iegaumēt un zināt faktus vai, precīzāk sakot, informāciju. Valda aizkustinoša ticība, ka cilvēks nonāk pie īstenības zināšanas, iekaļot arvien vairāk un vairāk faktu. Skolēnu galvās tiek „bāzti” simtiem izkaisītu, savstarpēji nesaistītu faktu; visu vin, laiku un energiju paņem arvien jaunu un jaunu faktu mācǐšanās, tāpēc domāšanai atliek pavisam nedaudz. Protams, domāšana bez faktu zināšanas ir tukša un fiktīva, taču kaila „informācija” var būt tikpat liels šķērslis domāšanai kā tās trūkums.

Cits paṇēmiens, kas, gluži tāpat kā iepriekš minētais, kavē oriğinālu domāšanu, ir jebkādas patiesības relativizācija. ${ }^{3}$ Patiesība tiek uzlūkota kā metafizisks koncepts, un, ja kāds saka, ka vēlas atklāt patiesību, tad mūslaiku „progresīvie” domātāji vin,u nodēvē par atpalikušu. Tiek apgalvots, ka patiesība ir pilnībā subjektīva - teju vai gaumes - lieta. Tiek arī apgalvots, ka zinātnisku domāšanu vajagot atdalīt no subjektīviem faktoriem un ka tās uzdevums ir skatīt pasauli bezkaislīgi un neieinteresēti. Zinātniekam fakti jātver ar sterilām rokām - gluži kā ķirurgam operāciju zālē. Šāds relatīvisms, kas bieži piesaka sevi kā empīrisms vai pozitīvisms vai dižojas ar savām rūpēm par jēdzienu precīzu lietošanu, galu galā noved pie tā, ka domāšana zaudē savu pamatimpulsu - domājošā cilvēka vēlmes un intereses, tā vietā kḷūstot par mašinu, kas reǵistrē „faktus”. Gluži tāpat kā domāšana kopumā attīstìjās no nepieciešamības apgūt dzìves materiālo jomu, tā arī patiesības meklējumi sakṇojas indivīdu un sociālo grupu interesēs un vajadzībās. Bez šādas intereses nebūtu arī dziņas rast patiesību. Sabiedrībā allaž ir grupas, kuru intereses virza patiesība, un to pārstāvji ir bijuši cilvēciskās domas pionieri. Pastāv arī citas grupas, kuru intereses virza patiesības slēpšana, un šajā gadījumā interese tikai kaitē patiesības meklējumiem. Tamdēḷ jautājums ir nevis par 
to, vai pastāv ieinteresētība, bet gan kāda ir šĩ interese? Alkas pēc patiesības mājo ikvienā cilvēkā, jo, manuprāt, katrs cilvēks izjūt nepieciešamību pēc tās.

Pirmāmkārtām tas attiecināms uz personas orientēšanos ārpasaulē, un jo īpaši tas attiecināms uz bērniem. Katrs cilvēks bērnībā pieredz bezspēcības stāvokli, un patiesība ir viens no vājo stiprākajiem ieročiem. Taču indivīds ir ieinteresēts patiesībā ne tikai tāpēc, lai orientētos ārpasaulē; viṇa spēks daudzējādā ziņā ir atkarīgs no tā, vai viņš zina patiesību par sevi. Ilūzijas par sevi var noderēt kā kruḳi tiem, kuri nespēj iet uz savām kājām, taču tās padziḷina cilvēka vājumu. Indivīda lielākais spēks pamatojas viṇa personības maksimālā pilnveidē, un tas paredz maksimālu sevis pazī̌nanu. „Pazīsti pats sevi" - lūk, viens no fundamentālākajiem vēlējumiem cilvēka spēka un laimes sasniegšanai.

Līdzās jau minētajiem nosacījumiem pastāv arī citi faktori, kas aktīvi grauj to, kas vēl atlicis no vidusmēra pieaugušā patstāvīgas domāšanas spējas. Visnotal, plaša mūsu kultūras joma pilda tikai vienu funkciju - aizmiglot visus individuālās un sociālās dzīves pamatjautājumus, kas saistās ar psihologiskām, ekonomiskām, politiskām un ētiskām problēmām. Viens no šādiem dūmu aizsegiem ir apgalvojums, ka šīs problēmas ir pārāk sarežǵìtas un tāpēc nesaprotamas vidusmēra indivīdam. Patiesībā notiek gluži pretēji - lielākā daḷa personiskās un sociālās dzīves pamatproblēmu ir gaužām vienkāršas, turklāt tik vienkāršas, ka saprotamas teju katram cilvēkam. To iztēlošana - bieži vien apzināta - par tik sarežgítām, ka tās aptveramas vienīgi šauras jomas „speciālista” prātam, grauj cilvēka ticību savai spējai pašam domāt par patiesi nozīmīgiem jautājumiem. Indivīds jūtas bezcerīgi sapinies haotiski izkaisītu faktu tīklā un aizkustinošā pacietībā gaida, līdz „speciālisti” viṇam norādīs, ko darīt un kurp doties.

Šādas ietekmes sekas ir divējādas. No vienas puses, tās izpaužas kā skepticisms un cinisms attieksmē pret visu runāto un rakstīto; no otras puses, kā bērnišķ̄ịa ticība itin visam, kas sacìts gana autoritatīvi. Šis cinisma un naivitātes savienojums ir l,oti raksturīgs mūsdienu indivīdam. Tā svarīgākais nolūks ir atturēt viņu no paša domāšanas un patstāvīgiem lēmumiem.

Vēl viens faktors, kas paralizē spēju domāt kritiski, ir jebkādas strukturētas pasaules ainas graušana. Fakti zaudē to specifisko iezīmi, kas tiem piemistu kā strukturēta veseluma dạ̦ām, un patur tikai abstraktu, kvantitatīvu nozìmi; katrs fakts ir tikai vēl viens fakts, un svarīgs šķ̧iet vien tas, 
vai mēs tos zinām lielākā vai mazākā apjomā. Graujošs iespaids šajā ziṇā ir radio pārraidēm, kinofilmām un preses izdevumiem. Pēc sižeta par pilsētu bombardēšanu un simtiem cilvēku bojāeju apkaunojoši rāda - vai to pat pārtrauc - ziepju vai vīna reklāma. Tas pats diktors tajā pašā suǵestīvajā, pieglaimīgajā un autoritatīiajā balsī, kas tik tikko iespaidīgi ziņoja par politiskās situācijas nopietnību, tagad informē publiku par pārraides reklāmdevēja ziepju ražotāja produkcijas teicamajām īpašībām. Kinohronikas formāts lauj rādīt torpedētus kuǵus pamīšus ar modes skates ainām. Laikraksti vienlīdz nopietni un apjomīgi atreferē jaunas kinozvaigznes banālās atziñas un brokastu ěšanas paradumus un svarīgākos notikumus zinātnē un kultūrā. Visu šo iemeslu dēḷ mēs zaudējam patiesu saikni ar dzirdēto. Mēs vairs neuztraucamies; mūsu emocijas un kritiskie spriedumi atslābinās, un beigu beigās mūsu attieksme pret notikumiem pasaulē top sekla un vienaldzīga. „Brīvības” vārdā dzīve zaudē jebkādu strukturētību; tā sastāv no daudziem maziem gabaliņiem, kas atdalīti cits no cita un kam trūkst nojausmas par veselumu. Indivīds ir atstāts vienatnē ar šīm druskām gluži kā bērns ar spēḷ klucī̌siem; atšķirīiba vien tā, ka bērnam ir nojēga par māju un viņš spēj saskatīt būves detaļas rotaļu klucǐšos, turpretī pieaugušais neapjauš tā „veseluma” nozīmi, kura daļas nonāk viņa rokās. Viņš ir apmulsis un nobijies un tikai skatās uz mazajiem gabaliņiem, nezinot, ko ar tiem iesākt.

Viss iepriekš teiktais par „orig̣inalitātes” trūkumu jūtās un domāšanā tikpat lielā mērā attiecināms arī uz gribu. Šo problēmu atpazīt ir īpaši grūts uzdevums, jo rodas iespaids, ka mūsdienu cilvēkam vēlmju ir gana, ka viņš zina, ko grib, un ka viṇa vienīgā problēma ir iegūt kāroto. Visa mūsu enerğija ir vērsta uz vēlmju piepildīšanu, un lielākā daḷa cilvēku nekad neiedomājas par šīs rīcības pirmcēloni, proti, vai viņi zina, ko vēlas, un patiesi vēlas to, pēc kā dzenas. Skolā viņi grib iegūt labas atzīmes, vēlāk, kḷūdami pieauguši, viņi grib tapt arvien veiksmīgāki, nopelnīt arvien vairāk naudas, iemantot lielāku prestižu, nopirkt labāku automašīnu, apceḷot arvien jaunas zemes utt. Taču, ja viṇi uz mirkli apstātos šai trauksmainajā skrējienā, tad, iespējams, varētu sev pajautāt: „Ja es iegūšu šo jauno darbu, ja es nopirkšu labāku automašīnu, ja es došos šajā cel̦ojumā - ko tad? Kāda tam visam jēga? Vai to patiesi man vajag? Vai nav tā, ka es dzenos pēc mērķa, kam it kā vajadzētu darìt mani laimīgu, bet tas izslīd man no rokām, kolīdz es to sasniedzu?’ Šie jautājumi - ja tādi rodas - ir biedējoši, jo liek apšaubīt cilvēka aktivitātes 
dzilāko pamatu - viņa zināšanu par to, ko viņš vēlas. Tamdẹl cilvēki tiecas pēc iespējas drīzāk atgainnāt šìs satraucošās domas. Viniem šķ̧iet, ka tās uzmācās vien tāpēc, ka viṇi jutās nomākti vai pārguruši, un turpina dzīties pēc mërkiem, ko uzskata par saviem.

Tomēr šādos mirkḷos pavìd miglaina nojausma par patiesību. Šì patiesība vēsta, ka mūsdienu cilvēks dzīvo ilūzijā - viņam šķiet, ka viṇš pazīst savas vēlmes, lai gan patiesībā viņa vēlmes tikai atspoguḷo noteiktu standartu. Lai to atzìtu, vajag saprast, ka zināt savas patiesās vēlmes nav tik viegli, kā domā vairums l̦aužu; gluži pretēji, tas ir viens no grūtākajiem uzdevumiem cilvēka mūžāa. Mēs izmisīgi mēǵinām izvairīties no šis problēmas, pieņemot jau gatavus standarta mērķus, it kā tie būtu mūsu pašu izvēlēti. Mūsdienu cilvēks ir gatavs uzņemties lielu risku, kad cenšas sasniegt mērķus, ko uzskata par „saviem”, bet ārkārtīgi baidās riskēt, kolīdz lieta skar atbildību par paša mērkiiem. Rosīgu darbošanos viņš bieži maldīgi notur par pašnoteiktas darbības apliecinājumu, kaut arī labi zina, ka tā var būt tikpat nepatstāvīga kā aktiera rīcíba uz skatuves vai hipnozei pakḷautas personas darbība. Aktieris, kuram ir zināms lugas sižets, var sparīgi tēlot sev uzticēto lomu un pat sagudrot kādas replikas vai radoši iezīmēt tēla detaļas, bet tik un tā viņš ir tikai aktieris, lomas tēlotājs.

Īpašās grūtỉbas noteikt, cik lielā mērā mūsu vēlmes - un arī mūsu domas un jūtas - nebalstās mūsos pašos, bet tiek uzspiestas no ārienes, cieši saistās ar autoritātes un brīvības tēmu. Jaunlaiku vēstures gaitā Baznīcas autoritāti aizstāja Valsts autoritāte, bet Valsts autoritāti - sirdsapziņas vara. Mūsdienu laikmetā sirdsapziņu aizstāj konformisma instrumentu - veselā saprāta un sabiedriskās domas - anonīmā vara. Atbrīvojušies no senākajām, atklātajām autoritātes formām, mēs neredzam, ka esam kḷuvuši par jauna veida varas laupījumu. Mēs esam pārvērtušies robotos, bet naivi iedomājamies, ka esam apveltīit ar patstāingu gribu. Ši ìlūzija palīdz indivìdam palikt neziñā par savu nedrošibu, bet tas arī ir viss, ko var sniegt šāda ilūzija. Principā indivīda patỉba novājinās, tamdēl vinnš jūtas bezspēcīgs un ārkārtīgi nedrošs. Viņš dzīvo pasaulē, ar kuru zaudējis îstenu saikni un kurā katra persona un katra lieta ir tikusi instrumentalizēta, kurā viņ̧̌ pats ir kḷuvis par daḷu no mašīnas, ko iepriekš radījis pats ar savām rokām. Viņ̧̌ domā, jūt un vēlas to, ko, vinạprāt, no viņa gaida, lai viņš domātu, justu un vēlētos, un šajā procesā zaudē savu patību, kas vienīgà var tapt par brīva indivīda patiesas palāvības pamatu. 
Patības zaudēšana padziļina šaubas par savu identitāti un tāpēc pastiprina vajadzību pēc pakḷaušanās noteikumiem, konformisma. Ja es neesmu nekas cits, kā vien tas, ko, manuprāt, no manis sagaida citi, tad - kas gan esmu „es”? Iepriekš mēs redzējām, ka cilvēka šaubas par savu patību modās brīdī, kad sāka brukt viduslaiku stingrā hierarhija, kurā katram indivīdam bija ierādīta stingri noteikta, neapšaubāma vieta. Indivīda identitāte ir nozīmīga problēma mūsdienu filosofijā kopš Dekarta. Patlaban mēs uzskatām par pašsaprotamu, ka mēs esam mēs. Tomēr šaubas par patỉbas eksistenci joprojām pastāv un pat palielinās. Pirandello lugās ir spilgti parādīta šī mūsdienu cilvēka izjūta. Viņš uzdod jautājumu: „Kas es esmu?” Vai manai identitātei ir vēl kādi citi pierādījumi, izṇemot manu fizisko esību? Atšķirībā no Dekarta, kurš pauda apliecinājumu individuālai patībai, Pirandello to noliedz: „Man nav identitātes; patība eksistē vien̄̄gi kā atspogul,ojums tam, ko no manis sagaida citi. Es esmu tas, „kas jums tîk””

Šàds savas identitātes zaudējums vēl vairāk pastiprina vajadzību pēc konformisma. Tas nozīmē, ka cilvēks var būt drošs par sevi vienīgi tad, ja dzīvo atbilstoši citu gaidām. Ja mēs nedzīvojam saskaņā ar iztēloto standartu, tad riskējam ne tikai saņemt nosodījumu un nonākt arvien lielākā atstumtībā, bet arī zaudēt savas personības identitāti, kas jau var apdraudēt garīgo veselíbu.

Centieni atbilst citu gaidām, neatšķirties no apkārtējiem klusina šaubas par savu identitāti, un cilvēks iemanto zināmu drošību. Tomēr cena, ko viņš maksā, ir ḷoti augsta. Atsacī̌sanās no spontanitātes un individualitātes noved pie dzīves noplicināšanās. Psihologiskais robots dzīvo tikai biologiski, bet emocionāli un garīgi ir miris. Viņš kustas, itin kā dzīvs būdams, bet tikmēr dzīve kā smilšu graudiṇi slīd viņam caur pirkstiem. Mūsdienu cilvēks ir šķietami apmierināts un optimisma pārpilns, bet dziḷi sirdī jūtas nelaimīgs, faktiski atrodas uz izmisuma sliekšn,a. Viņš izmisīgi tveras pie visa individuālā; viņš grib būt „citāds”, un augstākā uzslava viṇa acīs ir „,būt kaut kas īpašam”. Mēs tiekam informēti, kā sauc dzelzceḷa kasieri, kas pārdod pasažieriem biḷetes; somas, spēḷ kārtis un portatīvie radioaparāti tiek "personalizēti”, tiem uzlipinot īpašnieka iniciālus. Tas viss norāda uz slāpēm pēc ,atškirīịā”, bet tā arī ir teju vienīgā individualitātes palieka. Mūsdienu cilvēks ir izsalcis pēc dzīves, taču, būdams automāts, viņš nespēj izjust dzīvi kā spontānu aktivitāti, tāpēc apmierinās ar jebkādu surogātu, kas viṇu 
satrauc un uzbudina - iedzeršanu, sporta spēlēm vai „zilā ekrāna” kaislību līdzpārdzīvojumiem.

Kāda tad ir brīvības nozīme mūsdienu cilvēka acīs?

Cilvēks ir atbrīvojies no ārējām saitēm, kas kavē rīkoties un domāt atbilstoši savām vēlmēm. Viṇš varētu brīvi darboties saskaṇā ar savu gribu, ja vien zinātu, ko pats vēlas, domā un jūt. Taču viņš nezina. Viņš paḳlaujas anonīmām autoritātēm un pieņem patību, kas nav viṇejā. Jo vairāk viņš tā dara, jo bezspēcīgāks jūtas un jo spēcīgāk izjūt tieksmi pielāgoties ārējām prasībām. Par spīti optimisma un iniciatīvas šķietamībai, mūsdienu cilvēks ir dziḷas bezspēcības pārṇemts; šì izjūta viṇu paralizē un liek bezcerīgi gaidīt tuvojošos katastrofu.

Pavirši raugoties, rodas iespaids, ka cilvēki veiksmīgi funkcionē gan ekonomiskajā, gan sabiedriskajā dzīvē, tomēr viṇpus glītās fasādes slēpjas dziḷi iesakņojusies neapmierinātība, ko ignorēt būtu bīstami. Ja dzīve netiek dzīvota un tamdēl zaudē savu jēgu, tad cilvēks ieslīgst izmisumā. Mirstot no fiziska bada, cilvēki nepaliek klusi un mierīgi; arī no garīga bada viņi nemirst klusībā. Ja attieksmē pret „normālu” cilvēku mūs interesēs tikai viṇa saimnieciskās vajadzības, ja mēs neman̄isim neapzinātās ciešanas, ko izjūt vidusmēra automatizēts pilsonis, tad mēs nespēsim saredzēt briesmas, ko mūsu kultūrai rada tās cilvēciskais pamats - gatavību pien,emt jebkādu ideolog̣iju un jebkādu vadoni, kas sola uzbudinājumu, un tādu politisku struktūru un simboliku, kas it kā piešķir nozīmi un sakārtotību indivīda dzīvei. Cilvēkarobota izmisums ir auglīga augsne fašisma politiskajiem mērķiem.

\section{BRĪVĪBA UN SPONTANITĀTE}

Līdz šim šajā grāmatā tika aplūkots tikai viens brīvības aspekts - bezspēcība un nedrošība, ko mūsdienu sabiedrībā izjūt izolēts indivīds, kurš tapis brīvs no visām saitēm, kas iepriekš dzīvei piešķīra jēgu un noturību. Mēs redzējām, ka indivīds nespēj paciest šādu atšķirtību; kā izolēta būtne viņš jūtas pilnīgi bezspēcīgs ārpasaules priekšā un tamdēḷ pārdzīvo ārkārtīgas bailes. Savas atšķirtības dẹl viņš ir zaudējis priekšstatu par pasauli kā vienotu veselumu un tādēḷ arī spēju orientēties pasaulē. Viņš mokās šaubās par savu patību, apšauba dzìves jēgu un beigu beigās arī jebkādus principus, kas varētu noteikt un virzìt viña rīcību. Gan bezspēcība, gan šaubas paralizē dzīvi, un cilvēks, lai dzīvotu, cenšas bēgt no brīvības, negatīvas brīvības. Vinš̌ tiek 
iedzīts jaunā jūgā; šis jūgs atšķiras no agrākajām saitēm, no kurām - lai gan autoritāšu vai sociālo grupu valdījumā - viňš nebija pilnībā atsvabinājies. Brīvība neatjauno zaudēto pal̦āvību, bet tikai palīdz aizmirst savu patību kā atsevišķu veselumu. Viņš rod jaunu, trauslu drošību, upurējot savas individuālās patības integritāti. Viņš izvēlas zaudēt savu „es”, jo nespēj paciest vienatni. Tādējādi brīvība - kā „brīvība no” - ieved jaunā jūgā.

Vai mūsu analīze mudina secināt, ka pastāv neizbēgams cikls, kas ved no brīvības uz jaunu atkarību? Vai brīvība no visām sākotnējām saitēm padara cilvēku tik vientul,u un izolētu, ka viņam neizbēgami jāmeklē patvērums jaunā atkarībā? Vai neatkarība un brīvība ir sinonīmi izolācijai un bailēm? Vai tomēr pastāv pozitīva brīvība, kurā indivīds eksistē kā neatkarīga patība - ne izolēts, bet, gluži pretēji, vienots ar pasauli, citiem cilvēkiem un dabu?

Mēs uzskatām, ka atbilde var būt apstiprinoša, ka arvien pieaugošas brīvības process nerada apburto loku un ka cilvēks var būt brīvs - un tomēr ne vientuḷ̌šs kritiski domājošs - un tomēr ne šaubu pārpilns, neatkarīgs - un tomēr kā cilvēces neatņemama sastāvdaḷa. Šādu brīvìbu cilvēks var iemantot, îstenojot savu patību, esot pats. Kas ir sevis īstenošana? Filosofi ideālisti domāja, ka pašrealizāciju var sasniegt vienas vienīgas intelektuālas atskārsmes ceḷa. Viņi uzstāja, ka nepieciešams sašķelt cilvēka personību, lai prāts varētu apspiest un apsargāt cilvēka iedabu. Tomēr šādas sašķeltîbas dēl tikusi sakroplota ne tikai cilvēka emocionālā dzīve, bet arī vin,a intelektuālās spējas. Prāts, tapis par uzraugu savai cietumniecei - dabai, arī pats kluva par ieslodzìto, un abas cilvēka personības puses - prāts un jūtas - ieguva kroplīgas aprises. Mūsuprāt, patība tiek īstenota ne vien domāšanas aktā, bet arī atskārsmē par cilvēka personības veselumu, viņa emocionālo un intelektuālo iespēju aktīvā izpausmē. Šāds potenciāls piemīt ikvienam, bet iespējas top reālas, vien ciktāl tās tiek izpaustas. Citiem vārdiem sakot, pozitīva brīvība paredz veselas, nesašķ̧eltas personības spontānu aktivitāti.

Šeit mēs nonākam pie vienas no grūtākajām psihologijijas problēmām: spontanitātes problēmas. Lai to pienācīgi risinātu, būtu nepieciešama vesela grāmata. Tomēr, pamatojoties uz iepriekš teikto, mēs varam nonākt pie sapratnes par spontānas aktivitātes būtību, skatoties „no pretējās puses”. Spontāna aktivitāte nav darbība, ko indivīds veic piespiedu kārtā savas izolētîbas un bezspēcības dẹl, Tā nav robota automātiska darbība - ārēji 
uztieptu paraugu nekritiska pārņemšana. Spontāna aktivitāte - tā ir paša cilvēka brīva rīcība un psihologiski paredz latīnu valodas vārda sponte burtisko nozīmi - „pēc paša gribas”. Ar aktivitāti mēs domājam nevis „kaut kā darī̌̌anu”, bet gan tādu radošu darbību, kas var izpausties cilvēka emocionālajā, intelektuālajā un jutekliskajā pieredzē un arī viņa gribā. Viena no šās spontanitātes noteiksmēm ir veselas, nesašķeltas personības pien,emšana un „prāta” un „dabas” pretstata novēršana. Jo spontāna aktivitāte ir iespējama vien tad, ja cilvēks neapspiež savas patības būtiskas sastāvdaḷas, vien tad, ja viņš kḷūst caurredzams sev pašam, un tikai tad, ja dažādas dzìves jomas saliedējas fundamentālā veselumā.

Lai gan mūsu kultūrā spontanitāte ir samērā reta parādība, tomēr nav tā, ka tās mums trūktu pilnībā. Lai palīdzētu izprast šo situāciju, vēlos atgādināt lasītājam par dažām norisēm, kurās mēs viegli saredzam spontanitātes izpausmes.

Pirmāmkārtām mēs zinām cilvēkus, kuri ir - vai bija - spontāni un kuru domāšana, jušana un darbošanās apliecina viņu patību, ne automātiskas robota reakcijas. Šie cilvēki lielākoties ir pazīstami kā mākslinieki. Būtībā mākslinieks ir cilvēks, kas spēj īstenot spontānu pašizpausmi. Pieņemot šādu mākslinieka definīciju (Balzaks deva priekšroku tieši šim raksturojumam), par māksliniekiem varētu saukt arī dažus filosofus un zinātniekus, kuri no saviem kolēgiem atškiras, tāpat kā radošs gleznotājs atškiras no vecmodīga fotogrāfa. Mēs zinām arī cilvēkus, kuriem trūkst māksliniecisku dotību (vai varbūt tikai skološanās iespēju) izpausties materiāā tā kā to dara mākslinieks, bet kuriem tomēr piemīt tā pati spontanitāte. Mākslinieka stāvoklis ir trausls, jo viņam ir jābūt l,oti veiksmīgam, lai viņa individualitāte vai spontanitāte tiktu respektēta. Ja viņam nesekmējas pārdot savus darbus, tad laikabiedru acīs viņš ir tikai dīvainis vai „neirotiķis”. Šajā ziņā mākslinieks cilvēces vēsturē līdzinās revolucionāram. Veiksmīgs revolucionārs ir valstsvīrs, neveiksmīgs - noziedznieks.

Citu spontanitātes paraugu mums rāda mazi bērni. Viņiem piemīt spēja just un domāt to, kas ir patiesi viņējais; šĩ spontanitāte izpaužas vinuu teiktajā un domātajā, viṇu sejā atspoguḷotajās izjūtās. Ja mēs jautātu, kamdēḷ cilvēkiem lielākoties patīk mazi bērni, tad, neņemot vērā sentimentālus un konvencionālus iemeslus, atbilde tā vai citādi norādītu uz šo spontanitāti. Tāa uzrunā ikvienu, kas vēl nav tiktāl zaudējis emocionālo 
spēju, lai nesajustu tās dziḷo ietekmi. Būtībā nav nekā pievilcīgāka un pārliecinošāka par spontanitāti, vienalga, kur tā izpaužas - bērnā, māksliniekā vai jebkurā citā cilvēkā.

Gandrīz ikviens no mums var novērot kaut vai dažus mūsu pašu spontanitātes brīžus, kas pārtop īstas laimes mirkḷos. Tā var būt svaiga un spontāna ainavas uztvere, tā var būt atskārsme par kādu patiesību, kas dzimst mūsu domāšanas gaitā, tā var būt neierasta jutekliska tīksme vai uzviḷnojošs maigums mīlestībā pret otru cilvēku - šādos brī̌̌os mēs katrs zinām, kas ir spontāns pārdzīvojums, un gūstam nojausmu par to, kāda varētu būt mūsu dzīve, ja šie pārdzīvojumi nebūtu tik reti, nejauši un negaidīti.

Kāpēc tieši spontāna aktivitāte ir atbilde uz jautājumu par brīvību? Mēs jau konstatējām, ka negatīvā brīvība pārvērš cilvēku izolētā būtnēe kuras attieksme pret pasauli ir atsvešināta un pilna neuzticības un kuras patība ir vāja un pastāvīgi apdraudēta. Spontāna aktivitāte ir vienīgais ceḷš̌, kuru ejot cilvēks spēj pārvarēt bailes no vientulības, neatsakoties no sava „es” veseluma un pilnības, jo spontāna savas patības īstenošana cilvēku no jauna vieno ar pasauli - citiem cilvēkiem, dabu un sevi pašu. Mīlestība ir šādas spontanitātes svarīgākā sastāvdaḷa - ne mīlestība kā sevis pazaudēšana otrā cilvēkā, ne mīlestîba kā otra cilvēka piesavināšanās, bet mīlestîba kā citu cilvēku spontāna apliecināšana, kā indivīda vienība ar citiem uz savas individualitātes saglabāšanas pamata. Šajā polaritātē arī rodams mīlestības dinamiskais raksturs: tā dzimst no nepieciešamības pārvarēt atšķirtību un ved uz saliedētību, nekādi nemazinot individualitāti. Otra spontanitātes sastāvdaḷa ir darbs - ne darbs kā piespiedu darbošanās, lai izbēgtu no vientulības, ne darbs kā tāda attieksme pret dabu, ko daḷēji nosaka vēlme pakḷaut, daḷēji - pielūgt to un izmantot kā sava darba augli, bet darbs kā radošs process - radīšanas akts, kurā cilvēks top vienots ar dabu vienā veselumā. Viss iepriekš teiktais par mīlestību un darbu attiecas arī uz jebkādu spontānu aktivitāti, vienalga, vai tā saistīta ar jutekliskas baudas pārdzīvojumu vai līdzdalību sabiedrības politiskajā dzìvē. Tā apliecina patības individualitāti, vienlaikus vienojot patību ar cilvēku un dabu. Brīvībai piemītošā pamatpretruna - individualitātes dzimšana un vientulības sāpes - atrisinās augstākā pakāpē cilvēka spontānas aktivitātes rezultātā.

Jebkura veida spontānā aktivitātē indivīds aptver visu plašo pasauli. Individuālā patība ne tikai paliek neskarta, bet arī spēcinās, iemanto 
rūdījumu. Jo patība ir tik spēcīga, cik tā ir darbīga. Patiesu spēku nesniedz piesavināšanās - nedz materiālu labumu, nedz garīgu īpašību, piemēram, emociju vai domu īpašošana. Spēku nedāvā arī manipulācijas ar objektiem, to izmantošana; tas, ko lietojam, nav mūsu tikai tāpēc, ka mēs to lietojam. Mūsu ir tikai tas - vienalga, cilvēks vai nedzīvs priekšmets -, ar ko mūs īsteni saista radoša aktivitāte. Vienīgi tās īpašības, kas izriet no mūsu pašu spontānās aktivitātes, spēcina patību un tādējādi veido personības veseluma pamatu. Nespēja rīkoties spontāni, paust savas patiesās jūtas un domas un no tā izrietošā nepieciešamība prezentēt sev un citiem pseidopatību, ir cēlonis atsvešinātībai un vājuma izjūtai. Vai nu mēs to apzināmies, vai ne, bet mūsu lielākais apkaunojums ir nespēja būt pašiem, turpretī lielāko lepnumu un laimi sniedz spēja domāt, just un izteikt to, kas dzimis mūsu sirdī.

No iepriekš teiktā izriet, ka vērtīga ir pati darbība, nevis tās rezultāts. Tomēr mūsu sabiedrībā valda pretējs uzskats. Mūsu darbošanās uzdevums nav apmierināt noteiktas vajadzības; mēs dzenamies pēc abstrakta mērķa - pārdot savus ražojumus. Mēs apšaubām, ka pērkot varam iegūt visus materiālos un nemateriālos labumus, tādējādi lietas nonāk mūsu īpašumā neatkarīgi no mūsu radošajiem pūliṇiem attieksmē pret šīm lietām. Gluži tāpat - proti, kā preci - mēs uzlūkojam gan mūsu personiskās ìpašỉbas, gan sava darba rezultātu, ko iespējams pārdot, pretī gūstot naudu, prestižu un varu. Tā uzsvars pāriet no apmierinājuma, ko sniedz radoša darbošanās, uz gatavā produkta vērtību. Tādējādi cilvēks zaudē vienīgo apmierinājumu, kas varētu dāvāt viņam īstu laimi, - tagadējā brīža aktivitātes pārdzīvojumu, un dzenas pakal mirāžai - iluzorai laimei vārdā „veiksme”, kas liks vilties, kolīdz būs sasniegta.

Ja cilvēks spontānā aktivitātē atskārš savu patību un tādējādi saista sevi ar pasauli, tad viņš pārstāj būt izolēts atoms - viņš un pasaule kḷūūt par daḷu no viena sakārtota veseluma, kurā cilvēkam ir sava pienācīga vieta, un tādējādi izgaist viņa šaubas par sevi pašu un dzīves jēgu. Šìs šaubas dzima no viņa atšķirtības un dzīves aiztures; kolīdz viņšs spēj dzīvot - ne piespiedu kārtā vai automātiski, bet spontāni -, tā šaubas pazūd. Cilvēks sevi apzinās kā aktīvu un radošu individualitāti un atzīst, ka pastāv tikai viena dzìves jēga-pati dzìvošana.

Ja cilvēks pārvar pamatšaubas par sevi un savu vietu dzīvē, ja viņš saliedējas ar pasauli, aptverot to spontānas dzīvošanas aktā, tad viņš kā indivīds 
iemanto spēku un arī drošỉbu. Taču šĩ drošība atšķiras no pirmsindividuālā stāvokḷa drošības, gluži tāpat kā jaunā saliedētība ar pasauli atšķiras no tās sākotnējām saitēm. Jaunās drošǐbas pamats nav aizsardzība, ko indivīdam sniedz kāda ārpus viņa stāvoša augstāka vara. Šî jaunā drošība arī netiecas ignorēt dzīves traǵisko pusi. Tā ir dinamiska un pamatojas nevis aizsardzībā, bet cilvēka spontānā aktivitātē. Tā ir drošība, ko ik mirkli sniedz cilvēka spontānā aktivitāte. Šo drošỉbu spēj dāvāt tikai brīvība, un tai nav vajadzīgas ilūzijas, jo tā ir novērsusi apstākḷus, kas rada ilūziju nepieciešamību.

Pozitīvā brīvība kā savas patības îstenošana paredz indivìda unikalitātes pilnīgu apliecinājumu. Cilvēki piedzimst vienlīdzīgi, taču atšķirīgi. Šīs atšķirības pamats ir cilvēka iedzimtas īpašības - viņa fizioloǵiskais un garīgais mantojums, ko viņš saņem dzīves sākumā un kuram pēcāk pievieno mūža gaitā uzkrāto pieredzi un pārdzīvojumus. Nav sastopami divi fiziskā ziṇā vienādi organismi, un tikpat unikāls ir personības individuālais pamats. İstena patības izaugsme allaž notiek uz noteikta pamata - tā ir organiska izaugsme, tikai šai vienai personai raksturīgā iedīgḷa atraisīšanās. Turpretī cilvēka-robota attīstība nav organiska. Šajā gadījumā izaugsme uz patības pamata ir bloķēta un îstenā „es” vietu ien,em pseidopatība, kas, kā redzējām iepriekš, būtībā ir ārēju domāšanas un jušanas paraugu piesavināšana. Organiska izaugsme ir iespējama vienīgi tad, ja cilvēks dziḷi ciena patības sevišķumu gan citos cilvēkos, gan sevī. Šì cieņa pret ìpatnību un patības unikalitātes izkopšana ir cilvēces kultūras vērtīgākais sasniegums. Tieši šis sasniegums mūsdienās ir apdraudēts.

Patības unikalitāte nekādā ziṇā nav pretrunā ar vienlīdzības principu. Tēze, ka visi cilvēki piedzimst vienlīdzīgi, paredz to, ka viņiem piemīt vienas un tās pašas fundamentālās cilvēciskās īpašỉbas. Mums visiem ir lemts cilvēcisks liktenis, un katram no mums ir dotas neatñemamas tiesības uz brīvību un laimi. Tātad cilvēcisko attiecību pamatā ir jābūt solidaritātei, nevis valdonībai un paklautîbai. Vienlīdzība nenozīmē to, ka visi cilvēki ir vienādi. Šāds vienlīdzības traktējums izriet no indivīda lomas mūsdienu ekonomiskajā dzīvē. Pircēja un pārdevēja attiecībās atškirīgām personības iezīmēm ir maza vērtība. Šajā situācijā nozīme ir tikai tam, ka vienam no vin,iem pieder prece, ko pārdot, bet otram - nauda, lai šo preci iegādātos. Ekonomiskajā dzīvē viens cilvēks neatšķiras no otra, lai gan kā reāli cilvēki viņi ir atšķirīgi un viņu unikalitātes izkopšana ir individualitātes būtība. 
Pozitīivā brīvība arī paredz principu, ka nav augstākas varas par šo unikālo individuālo patîbu - cilvēks ir savas dzīves centrs un mērķis, bet cilvēka individualitātes izaugsme un realizācija ir uzdevums, kas nekādos apstākḷos nevar tikt pakḷauts citiem, šşietami diženākiem mērķiem. Šãds skaidrojums var izraisit nopietnus iebildumus. Vai tas nepostulē neapvaldìtu egoismu? Vai tas nenoliedz ideju par ziedošanos ideāla vārdā? Vai ša principa atzīšana nenoved pie anarhijas? Vairāk vai mazāk izvērstas atbildes uz šiem jautājumiem ir dotas iepriekšejēās nodạ̣ās, tomêr problēma ir pārāk nozīmīga, lai mès necenstos tàs vēlreiz pamatot un tādējādi izbēgt no varbūtējiem pārpratumiem.

Apgalvojums, ka cilvēks nedrîkst būt pakḷauts kaut kam augstākam par sevi pašu, nebūt nenoliedz, bet, gluži pretēji, stingri apliecina ideālu nozīmību. Tomēr tas liek kritiski izvērtēet jēdziena ,ideāls” saturu. Mūsdienās daudzi sliecas domāt, ka ideāls ir katrs mērķis, kura sasniegšana neparedz materiāla labuma gūšanu, vai jebkas, kā vārdā cilvēks ir gatavs upurēt savas egoistiskās intereses. Tā ir tîri psiholog̣iska - un šajā ziņā relatīivistiska - ideāla izpratne. No šāda subjektīva skatpunkta raugoties, fašists, kuru motivē alkas pakḷauties augstākai varai un vienlaikus paverdzināt citus cilvēkus, ir tikpat liels ideālists kā cīnītājs par humānām vērtībām - brīiỉbu un vienlīdzību. Uz šāda pamata jautājums par ideālu nav atrisināms.

Mums jāatzīst atšḳirīiba starp īsteniem un iedomātiem ideāliem. Šì atšḳirỉba ir tikpat fundamentāla kā atškiriība starp patiesību un meliem. İsteniem ideāliem piemīt viena kopịga īpašỉba - tie pauž alkas pēc kaut kā tāda, kas vēl nav sasniegts, bet ir vēlams indivìda izaugsmes un laimes vārdā. ${ }^{4}$ Mēs varbūt ne vienmēr zinām, kas kalpo šim mērķim, mēs varam diskutēt par tā vai cita ideāla funkciju cilvēciskās attīstîbas ziņā, taču tas nav pamats relatīvismam, kas paredz nezināšanu par to, kas sekmē dzīvi vai kavē to. Mēs ne vienmēr esam droši par tās vai citas pārtikas veselīgumu vai kaitīgumu, bet tāpēc jau vēl nesecinām, ka indes vispār ir neatpazīstamas. Gluži tāpat mēs varam zināt - ja gribam zināt -, kas saindē garīgo dzìvi. Mēs zinām, ka dzīvei kaitē nabadzība, iebiedēšana, izolācija. Mēs arī zinām, ka dzīves uzplaukumu sekmē viss, kas kalpo brīvỉbai un stiprina drosmi un varēšanu būt pašam. Jautājums par to, kas cilvēkam ir labs vai slikts, ir nevis metafizisks, bet gan empīrisks - uz to var atbildēt, analītiski izvērtējot cilvēka iedabu un noteiktu apstākḷ ietekmi uz cilvēku. 
Bet kā ar, teiksim, fašistu ,ideāliem”, kas neapšaubāmi ir vērsti pret dzīvi? Kā izprast faktu, ka cilvēki seko šiem viltus ideāliem tikpat dedzīgi kā citi seko īstiem ideāliem? Atbildi uz šo jautājumu sniedz zināmi psihologiski apsvērumi. Mazohisma fenomens liecina, ka cilvēkus var saistīt ciešanu vai pakḷautības pārdzīvojumi. Nav šaubu, ka ciešanas, pakḷautība vai pašnāvība ir antitēze pozitīviem dzīves centieniem, bet arī šos mērķus var subjektīvi pārdzīvot kā pievilcīgus un apmierinājumu sniedzošus. Dziṇa pēc tā, kas nodara kaitējumu dzīvei, ir parādība, kas vislielākajā mērā saucama par „patologisku perversiju”. Daudzi psihologi pieņem, ka tīksmes pārdzīvojums un vairīšanās no sāpēm ir vienīgie leǵitīmie principi, kas vada cilvēka rīcību, taču dinamiskā psihologíja rāda, ka subjektīvs tīksmes pārdzīvojums nav pietiekams kritērijs, vērtējot cilvēka uzvedību viṇa laimes kontekstā. Tipisks piemērs ir mazohisma analīze. Tā parāda, ka baudas izjūta var izrietēt no patologiskas perversijas un tikpat maz atklāj pārdzīvojuma objektīvo nozīmi kā indes saldā garša mums atklāj tās iedarbību uz organismu. ${ }^{5}$ Tādējādi mēs definējam īstenu ideālu kā jebkura veida centienus, kas sekmē patības izaugsmi, brīivibu un laimi, bet viltus ideālu - kā tos piespiedu iracionālos mērḳus, kas subjektīvi saistās ar patīkamu pārdzīvojumu (piemēram, dziṇā pēc pakḷautîbas), bet patiesībā kaitē dzìvei. Pien,emot šādu definīciju, mēs varam secināt, ka īstens ideāls ir nevis kaut kāds indivīdam neredzams, par viņu augstāks spēks, bet gan viņa patības pilnīga apliecinājuma skaidra izpausme. Jebkuri mērḳi, kas ir pretrunā ar šādu apliecinājumu, ir nevis ideāli, bet patologiski centieni.

Šeit mēs nonākam pie jautājuma par upurēšanos. Vai mūsu uzskats par brīivibu kā nepakḷaušanos jebkādai augstākai varai izslēdz upurēšanu, tostarp savas dzīves upurēšanu kaut kāda mērķa vārdā?

Šis jautājums ir sevišk ki svarīgs mūsdienās, kad fašisms sludina pašupurēšanos kā augstāko tikumisko vērtību un daudzus ietekmē ar savu ideālistisko raksturu. Atbilde uz šo jautājumu logiski izriet no iepriekš teiktā. Pastāv divi pilnīgi atšķirīgi upurēšanas tipi. Viens no cilvēka dzīves traǵiskajiem faktiem ir mūsu fiziskās patības un mūsu garīgā „es” centienu potenciālais konflikts - lai apliecinātu savas garīgās būtības veselumu, cilvēks var būt spiests upurēt savu fizisko esību. Šāds upuris vienmēr būs trağisks. Nāve nekad nav salda - arī tad, ja tiek pieņemta augstākā ideāla vārdā. Tā allaž ir neizsakāmi rūgta un tomēr var kalpot kā cilvēka individualitātes augstākais 
apliecinājums. Šāds upuris fundamentāli atškiras no fašisma sludinātās ,upurēšanās". Fašisma gadījumā sevis upurēšana ir nevis augstākā cena, ko cilvēks var maksāt, lai apliecinātu savu patîbu, bet gan pašmēerķis. Šāda mazohistiska upurēšana dzīves piepildījumu saskata tās noliegumā, patîbas iznīcināšanā. Lūk, spilgtākais piemērs fašisma centieniem visās to dažādajās izpausmēs cilvēka patības iznīcināšana un tās pilnīga pakḷaušana augstākai varai. Tā ir upurēšanās patolog̣ija tikpat lielā mērā kā pašnāvība ir dzīves piln̄̄gākais izkrop̣̣ojums. Patiesa upurēšana paredz nesatricināmu vēlmi pēc garīga veseluma. Tie, kas šo vēlmi zaudējuši, upurējoties demonstrē vien savu morālo bankrotu.

Aplūkosim vēl pēdējo iebildumu: ja cilvēkiem ir l̦auts darboties brīvi, spontāni un vinịi neatzīst augstāku autoritāti par savu patību, vai šāda situācija nenovēršami neved pie anarbijas? Ja ar vārdu ,anarhija” mēs saprotam neiegrožotu egoismu un destruktivitāti, tad noteicošais faktors būs mūsu izpratne par cilvēka iedabu. Es varu atsaukties tikai uz to, kas izklāstits nodạ̦ā par bēgšanas mehānismiem: cilvēks nav nedz labs, nedz ļauns; cilvēka dzīvei piemīt iekšêja dziṇa, kas vêrsta uz izaugsmi, attīstību un potenciālo dotumu izpausmi; ja dzìve ir traumēta, ja indivīds ir izolēts vai šaubu mocìts, vai jūtas vientuḷ̂š un bezspēcīgs, tad viṇu pārṇem dziṇa pēc destruktivitātes un alkas pēc varas vai pakḷaušanās. Turpretī pozitīvi apliecinošās brīvības situācijā, kurā cilvēks spēj realizēt savu patîbu pilnībā un bez kompromisiem, zūd arī pamatcēlonis asociālām tieksmēm un šai ziṇā bīstami ir tikai slimi, garīgi neveseli indivīdi. Cilvēces vēsturē šāda brīvỉba vēl nekad nav tikusi isstenota, bet tā ir ideāls, uz ko cilvēce tiekusies pat tad, ja šie centieni bijušsi izteikti nejēdzīgās, iracionālās formās. Nav pamata brīnīties, kāpēc vēstures liecībās ir tik daudz cietsirdības un postītkāres. Manuprāt, pārsteidzošs - un tāpēc iedvesmojošs - ir vienīgi fakts, ka cilvēku dzimums, par spīti visam, kas noticis ar cilvēkiem, ir saglabājis un pat vēl izkopis tādas rakstura īpašǐbas kā, piemēram, cieņa, drosme, pieklājība un labestība, kuras mēs redzam gan visā vēstures gaitā, gan neskaitāmos l̦audīs mūsdienās.

Ja ar ,anarhiju” saprot indivīda nevēlēšanos atzìt jebkādu autoritāti, tad atbilde rodama iepriekš teiktajā par atšķ̧irību starp racionālu un iracionālu autoritāti. Racionāla autoritāte - tāpat kā īstens ideāls - reprezentē izaugsmes centienus un indivīda attīstību. Tā principā nevar būt pretrunā ar indivīdu un viña issteniem - ne patologiskiem - centieniem. 
Šìs grāmatas pamatatziņa ir tā, ka brīvībai mūsdienu cilvēka acīs ir divējāda nozīme: viņš ir ticis atbrīvots no tradicionālām autoritātēm un tapis „indivīds”, taču vienlaikus viņš ir kḷvis izolēts, bezspēcīgs, atsvešināts no sevis un citiem, tiek izmantots kā rīks ārēju mērķ̧u sasniegšanai. Turklāt šāds stāvoklis grauj cilvēka patību, vājina un biedē viṇu un mudina pakḷauties jaunam jūgam. Turpretī pozitīvā brīvība paredz gan indivīda potenciālo dotumu pilnīgu īstenošanu, gan viṇa spēju dzīvot aktīivi un spontāni. Brīvība ir sasniegusi to kritisko punktu, kurā savas attīstības iekšèjās logikas dēḷ tā draud pāriet savā pretmetā. Demokrātijas nākotne ir atkarīga no tā individuālisma īstenošanas, kas ir mūsdienu garīgās dzìves ideolog̣iskais mērķis jau kopš renesanses. Šodienas kulturālās un politiskās krīzes cēlonis ir nevis pārmērīgs individuālisms, bet gan apstāklis, ka tas, ko mēs uzskatām par individuālismu, ir pārvērties tukšā čaulā. Brīvības uzvara ir iespējama tikai tad, ja demokrātija attīstās sabiedrībā, kurā indivīds, viṇa izaugsme un laime ir kultūras jēga un mērḳis un kurā dzīvei nav nepieciešams attaisnojums panākumu vai jebkā cita formā, un kurā ārējā vara, vienalga, valsts vai ekonomiskā mašīna, valdonīgi nemanipulē ar indivīdu. Visbeidzot, tai jābūt sabiedrībai, kurā cilvēka sirdsapziņa un ideāli ir nevis ārēju prasību interiorizācija, bet gan paša noteiksmes un centieni, kas izriet no „es” neatkārtojamās īpatnības. Šie centieni nevarēja tapt īstenoti nevienā no iepriekšējiem jaunlaiku vēstures laikmetiem. Tiem vajadzēja palikt lielākoties ideolog̣iskiem mērḳiem, jo trūka materiālās bāzes patiesa individuālisma attīstībai. Kapitālisms ir radījis šo noteiksmi. Ražošanas problēma - vismaz principā - ir atrisināta, un mēs varam vizualizēt gaidāmo pārpilnību, kurā cīṇu par ekonomiskām privilēgijām vairs nenoteiks ekonomiska nepieciešamība. Šodien mēs saskaramies ar sociālo un ekonomisko spēku organizācijas problēmu, kurā cilvēks - kā organizētas sabiedrības loceklis - spētu kḷūt par šo spēku pavēlnieku un būt ne vairs to vergs.

Iepriekš es uzsvēru brīvības psihologisko aspektu, bet vienlaikus arī centos parādīt, ka psihologisku problēmu nevar nošksirt no cilvēka esības materiālā pamata, no sabiedrības ekonomiskās, sociālās un politiskās struktūras. No šīs premisas izriet, ka pozitīvās brīvības un individuālisma îstenošana ir arī cieši saistīta ar ekonomiskām un sociālām pārmaiņām, kas at l̦aus indivīdam tapt brīvam savas patības realizācijas izpratnē. Šìs 
grāmatas uzdevums nav risināt ekonomiskas problēmas, kas izriet no šīs premisas, vai kaldināt ekonomiskos plānus nākotnei. Tomēr es gribētu nešaubīgi iezīmēt virzienu, kurā saskatu problēmas atrisinājumu.

Pirmāmkārtām ir skaidri jāsaprot, ka mēs nevaram atḷauties zaudēt nevienu no modernās demokrātijas fundamentāliem sasniegumiem - nedz tās pamatu pamatu, proti, reprezentatīvo pārvaldes formu, kurā tauta ievēl valdītājus, kas tad ir atbildīgi tautas priekšā, nedz jebkuras tiesības, ko valsts satversme garantē katram pilsonim. Mēs arī nevaram upurēt jaunāku demokrātijas principu, kas paredz, ka neviens nedrīkst ciest badu, ka sabiedrība ir atbildīga par visiem tās locekḷiem, ka neviens nedrīkst tapt pazemots un zaudēt savu cilvēcisko lepnumu bailēs no bezdarba un izsalkuma. Šos galvenos sasniegumus vajag ne tikai saglabāt, bet arī stiprināt un izvērst plašumā.

Lai gan šie demokrātijas mērķi ir īstenoti, - protams, ne tuvu visā pilnībā -, ar to nepietiek. Demokrātijas progress paredz aktuālās brīvības, iniciatīvas un indivīda spontanitātes pilnveidošanu ne tikai šauri privātā sfērā vai garīgās lietās, bet vispirms cilvēka esībai fundamentālā aktivitātè - viņa darbā.

Kādi ir vispārīgie nosacījumi? Sabiedrības iracionālo bezplāna raksturu vajag aizstāt ar plānveida ekonomiku, kas reprezentē plānotus un saskaņotus visas sabiedrības pūliņus. Sabiedrībai nepieciešams pārvaldīt sociālo procesu tikpat racionāli, kā tā pārvalda dabu. Viens no nosacījumiem ir iestāšanās pret to slepeno varu, ko bauda neliela l̦aužu grupa, kas plaši saimnieko bez atbildības pret tiem, kuru liktenis ir atkarīgs no tās lēmumiem. Šo jauno kārtību mēs varam saukt par demokrātisko sociālismu, bet ne jau nosaukums ir svarīgs. Svarīgi ir nodibināt racionālu ekonomisku sistēmu, kas kalpo tautas interesēm. Mūsdienās lielākajai daļai cilvēku nav ne tik vien nekādas teikšanas par saimniecisko mašinēriju, bet arī gandrīz nekādu iespēju attīstīt patiesu iniciatīvu un spontanitāti savā darba laukā. Viņi ir „nodarbinātie” un no viņiem negaida neko citu kā vien rīkojumu izpildi. Vien̄̄gi plānveida ekonomikā, kurā visa nācija racionāli pārvalda ekonomiskos un sociālos spēkus, indivīds var uzņemties savu daḷu atbildības un savā darbā izmantot radošo domu. Svarīgi, lai indivīds atgūtu iespēju darboties pa īstam, lai sabiedrības un viņa paša mērķi pārklātos ne ideolog̣iski, bet dzīves īstenībā, lai savā darbā viņš aktīvi liktu lietā pūliṇus 
un saprātu un justu atbildību par savu darbu, jo tam piemīt jēgpilns saturs viṇa cilvēcisko uzdevumu kontekstā. Manipulāciju ar cilvēkiem mēs varam aizstāt ar aktīvu un saprātīgu sadarbību un formāli politisko pārvaldes principu „tautas vēlēta vara tautai” izvērst ekonomikas jomā.

Jautājums par to, vai ekonomiskā un politiskā sistēma veicina cilvēka brīvību, nevar tikt atbildēts, raugoties tikai no politikas vai ekonomikas skatpunkta. Brīvības īstenošanas vienīgais kritērijs ir tas, vai cilvēks aktīvi piedalās savas dzīves un arī sabiedrības dzīves noteikšanā, turklāt ne tikai formālā balsošanas aktā, bet savās ikdienas norisēs, savā darbā un attiecībās ar citiem cilvēkiem. Modernā politiskā demokrātija, ja tā iegrožota tīri politiskā jomā, nespēj pietiekami lielā mērā novērst vidusmēra indivīda ekonomiskās nenozīmības sekas. Nepietiek ar tīri ekonomiskiem konceptiem, tādiem kā ražošanas līdzekḷlu sabiedriskošana. Vārds „sociālisms” ir ieguvis mānīgu nozīmi, bet šajā gadījumā man prātā ir nevis nacionālsociālisms, kas to piesavinājies taktisku apsvērumu dēḷ, bet gan Krievija, kur, par spīti ražošanas līdzekḷ u sabiedriskošanai, patiesībā valda birokrātija, kas manipulē ar plašām tautas masām. Šis apstāklis neizbēgami novērš brīvības un individuālisma attīstību, pat ja pārvalde izrādās efektīva iedzīvotāju lielākās daļas ekonomiskajās interesēs.

Nekad agrāk vārdi nav tik lielā mērā apslēpuši patiesību, kā tas ir mūsdienās. Sabiedroto nodevību dēvē par eskalācijas mazināšanu, militāro agresiju iztēlo kā aizsardzību pret uzbrukumu, mazas valsts iekarošana notiek itin kā draudzības vārdā, bet veselas tautas brutāla apspiešana tiek īstenota zem nacionālsociālisma karoga. Tikpat kroplīgu nozīmi iemanto vārdi „demokrātija”, „brīvība” un „individuālisms”. Tomēr pastāv iespēja noteikt reālo atšķirīibu starp demokrātiju un fašismu. Demokrātija ir sistēma, kas rada ekonomiskus, politiskus un kultūras nosacìjumus indivīda pilnvērtīgai attīstībai. Fašisms ir sistēma, kas, lai kā to nosauktu, pakḷauj indivīdu ārpusējām interesēm un kavē patiesas individualitātes attīstību.

Acīmredzams, ka, veidojot apstākḷus demokrātijas īstenošanai, lielas grūtības rada pretruna starp plānveida ekonomiku un katra indivīda aktīvu līdzdarbošanos. No vienas puses, plānveida ekonomika ikvienas lielas industriālas sistēmas mērogā prasa lielu centralizāciju un tātad arī birokrātiju šīs centralizētās mašīnas administrēšanai. No otras puses, katra indivīda un veselās sistēmas mazāko vienību aktīva kontrole un sadarbība prasa lielu tiesu 
decentralizācijas. Plānveida ekonomika novedīs pie jaunas manipulācijas ar cilvēkiem, ja vien plānošanu no augšas nepapildinās aktīva līdzdarbība no apakšas un sociālās dzīves straume pastāvīgi neplūdīs no apakšas uz augšu. Atrisināt problēmu, kā savienot centralizāciju un decentralizāciju, ir viens no galvenajiem sabiedrības uzdevumiem. Šis uzdevums nebūt nav sarežǵgitāks par jau atrisinātām tehniskām problēmām, kas cilvēcei lāvis tik pilnīgi valdīt pār dabu. Tomēr tas atrisināms vien̄̄gi tad, ja mēs skaidri apzināmies šo nepieciešamību un mūsos mājo ticība cilvēkiem, viṇu spējai rūpēties par savām patiesajām cilvēciskajām interesēm.

Te mēs atkal nonākam pie jautājuma par individuālo iniciatīvu. Liberālā kapitālisma apstākḷ os individuālā iniciatīva bija viens no spēcīgākajiem stimuliem, kas veicināja gan ekonomiskās sistēmas, gan cilvēka personisko attīstību. Tomēr te jāmin atruna: tā attīstīja tikai dažas atsevišķas cilvēka, viņa gribas un prāta īpašîbas, bet citas l̦āva paḳlaut ekonomiskiem mērķiem. Vispilnīgāk šis princips izpaudās augsti individualizētā un brīvo konkurenci veicinošā kapitālisma fāzē, kurā netrūka vietas neskaitāmiem neatkarīgiem uzṇēmumiem. Mūsdienās šĩ telpa ir krietni sašaurināta. Vienīgi nedaudzi spēj praktizēt individuālu iniciatīivu. Ja mēs šodien gribam īstenot šo principu, to paplašināt tiktāl, lai taptu brīva personība savā veselumā, tad mums jāsaprot, ka to varēs panākt tikai tad, ja visa sabiedrība tam veltīs racionālus, saskaņotus pūliṇus un decentralizācija sasniegs tādu pakāpi, kas spēs garantēt sistēmas mazāko vienību reālu, patiesu, aktīvu sadarbibu un kontroli.

Vienīgi tad, ja cilvēks pārvalda sabiedrību un pakḷauj ekonomisko mašīnu cilvēciskās laimes mērḳiem, vienīgi tad, ja viņš aktīvi līdzdarbojas sociālajā procesā, viņš spēj pārvarēt to, kas pašlaik dzen viņu izmisumā - vientulību un bezspēcības izjūtu. Patlaban cilvēks cieš ne tik daudz no nabadzības, cik no apziņas, ka viņš ir pārtapis milzu mehānisma skrūvītē, robotā, ka viṇa dzìve ir zaudējusi saturu un nozīmi. Uzvara pār to vai citu autoritāro sistēmu būs iespējama tikai tad, ja demokrātija neatkāpsies aizmugurē, bet dosies uzbrukumā un īstenos tos mērķus, pēc kuriem tiekušies brīvības cīnītāji cilvēces vēstures pēdējos gadsimtos. Tā uzveiks nihilisma spēkus, ja spēs iedvest l̦audīm visspēcīgāko ticību, uz ko ir spējīgs cilvēka prāts, - ticību dzīvei un patiesībai, un brīvībai kā savas patības aktīvai, spontānai īstenošanai. 
PIELIKUMS

\section{CILVĒKA RAKSTURS UN SOCIĀLAIS PROCESS}

Grāmatas gaitā mēs aplūkojām noteiktus vēsturiskos laikposmus, piemēram, reformāciju un mūsdienas, un analizējām sociālekonomisko, psiholog̣isko un ideologiisko faktoru savstarpējo ietekmi. Lasītājiem, kurus interesē ar šo analīzi saistītās teorētiskās problēmas, es mēgeināšu pielikumā īsi ieskicēt to vispārīgo teorētisko satvaru, kas ir šīs konkrētās analīzes pamats.

Pētot sociālo grupu psiholog̣iskās reakcijas, mēs saskaramies ar grupas locekl,u, atsevišķu personu, rakstura struktūru, tomēr mūs interesē ne tik daudz šo cilvēku individuāāās atšķirības, cik tā viṇu rakstura struktūras daḷa, kas kopīga lielākajai daḷai grupas locekḷu. Šo rakstura iezīmju kopumu var saukt par sociālo raksturu. Protams, sociālais raksturs ir mazāk specifisks nekā individuālais raksturs. Aprakstot individuālo raksturu, mēs minam visas tās īpašỉbas, kas savā īpatnējā salikumā veido tā vai cita cilvēka personības struktūru. Sociālajā raksturā ietilpst tikai noteikta daḷa individuālā rakstura iezīmju, proti, lielākās dal̦as grupas locekḷu rakstura struktūras kodols, kas veidojies šās grupas dalībniekiem tipisku pārdzīvojumu un dzīves pieredzes rezultātā. Allaž būs , autsaideri” ar piln̄̄gi atšksirīgu rakstura struktūru, tomēr lielākās daḷas grupas locekḷu rakstura struktūra būs pamatkodola variācija, kas veidojusies dažādu nejaušu, katram indivīdam unikālu izcelsmes un dzīves pieredzes faktoru ietekmē. Ja mēs gribam pēc iespējas pilnīgāk izprast kādu cilvēku, tad šiem atšksirīgajiem elementiem ir vislielākā nozīme. Taču, ja gribam saprast, kā cilvēciskā enerǵija tiek virzīta noteiktā gultnē un operē kā produktīvs spēks noteiktā sociālā kārtībā, tad uzmanības centrā nonāk sociālais raksturs.

Sociālā rakstura konceptam ir galvenā loma sociālā procesa izpratnē. Cilvēka raksturs - analītiskās psiholog̣ijas dinamiskajā nozīmē - ir specifiska forma, kurā cilvēcisko enerǵiju veido cilvēka vajadzību dinamiska adaptācija noteiktas sabiedrības konkrētam eksistences modam. Savukārt raksturs nosaka indivīdu domāšanu, jūtas un rīcību. Attieksmē pret domāšanu tas var likties neticami, jo mēs visi sliecamies piekrist tradicionālajam uzskatam, ka domāšana ir viscaur intelektuāls akts, neatkarīgs no personības psihologiskās struktūras. Tomēr tā nav taisnība - un vēl jo mazāk gadījumā, 
ja mūsu domas saistās ar ētiskām, filosofiskām, politiskām, psiholog̣iskām vai sociālām problēmām, nevis empīriskām manipulācijām ar konkrētiem objektiem. Šāda veida domas - neatkarīgi no domāšanas aktā ietvertiem tīri log̣iskiem elementiem - lielā mērā determinē domājošã cilvēka personības struktūra. Tas attiecas gan uz doktrīnu vai teorētisku sistēmu kopumā, gan uz atsevišķiem jēdzieniem, piemēram, mīlestību, taisnīgumu, vienlīdzību, ziedošanos. Katram šādam jēdzienam un katrai doktrīnai ir sava emocionālā matrice, kas saknojas indivīda rakstura struktūrā.

Iepriekšējās nodalāàs mēs redzējām daudzus konkrētus piemērus. Saistībā ar doktrīnām mēs centāmies atsegt agrīnā protestantisma un mūsdienu autoritārisma emocionālās saknes. Saistībā ar atsevišķiem jēdzieniem mēs parādījām, ka, teiksim, sadomazohistiskam raksturam mīlestība nozīmē simbiotisku atkarību, ne savstarpēju apliecinājumu un savienību uz vienlīdzības pamata. Ziedošanās tam nozīmē individuālā „es” pilnīgu pakḷaušanu kaut kam augstākam, ne garīgās un ētiskās patības apliecinājumu, cilvēku dažādība - atšķirību varas sadalē, ne individualitātes realizāciju uz vienlīdzības pamata, taisnīgums - noteikumu, ka katram jāsaņem pēc nopelniem, ne cilvēka beznosacījumu prasību pēc savu no dzimšanas doto un neatņemamo tiesību īstenošanas, drosme - gatavību paḳ̣auties un paciest ciešanas, ne savas individualitātes augstāko apliecinājumu, nostājoties pretī varai. Kad divi dažādi cilvēki runā, piemēram, par mīlestību, tad viņi izmanto vienu un to pašu vārdu, taču šī vārda nozīme var būt gana atšķirīga - to nosaka katra sarunas biedra rakstura struktūra. Patiesi, jēdzienu nozīmes pareiza psihologiskā analīze mums ḷautu izvairīties no daudziem intelektuālas dabas pārpratumiem, jo tīri log̣iska klasifikācija ir neizbēgami lemta neveiksmei.

Kultūras gara izpratnei ārkārtīgi nozīmīgs ir fakts, ka ideja pamatojas emocionālā matricē. Dažādām sabiedrībām vai vienas sabiedrības dažādiem slān,iem piemīt specifisks raksturs, un uz tā pamata attīstās un gūst ietekmi dažādas atšķirīgas idejas. Piemēram, ideja par darbu un veiksmi kā galvenajiem dzīves mērķiem varēja kḷūt ietekmīga un pievilcīga mūsdienu sabiedrībā mūsdienu cilvēka vientulības un šaubu dẹl, Turpretī mēginājums iedvest ideju par nemitīgiem pūliņiem un centieniem pēc panākumiem pueblo indiāņiem vai meksikāṇu zemniekiem izrādītos pilnīgi veltīgs. Šiem laudīm piemīt gluži citāda rakstura struktūra nekā mūsdienu rietumniekiem, 
un maz ticams, ka viņi saprastu jūsu teikto, pat ja jūs runātu viņu valodā. Tāpat Hitlers un tā daḷa Vācijas iedzīvotāju, kuriem piemīt viṇam līdzīga rakstura struktūra, fanātiski tic, ka ikviens cilvēks, kurš uzskata, ka karš ir novēršams, ir vai nu piln̄̄gs mul,kis, vai tīrais melis. Viṇu sociālais raksturs mudina domāt, ka dzīve bez ciešanām un posta ir tikpat neiedomājama kā brīvība un vienlīdzība.

Idejas bieži apzināti pieņem noteiktas grupas, kas sava sociālā rakstura īpatnību dēḷ patiesībā uztver tās visai pavirši. Šìs idejas saglabājas vien kā apzinātu principu kopums, bet kritiskā brīdī cilvēki nerīkojas saskaṇā ar tām. Tipisks piemērs ir vācu strādnieku kustība nacisma uzvaras periodā. Pirms Hitlers nāca pie varas, lielākā daḷa vācu strādnieku balsoja par sociālistu vai komunistu partijām un ticēja šo partiju propagandētajām idejām, proti, šo ideju izplatība strādnieku vidē bija ārkārtīgi plaša. Tomēr šo ideju svars ne tuvu nelīdzinājās to izplatībai. Nacisma uzvaras gājiens nesastapa politisku pretestību, jo vairums oponentu nebija gatavi cīnīties par savām idejām. Kaut arī daudzi kreiso partiju atbalstītāji ticēja savu partiju programmām, kamēr šīs partijas saglabāja autoritāti, krīzes stundā tūlin, pat atteicās no tām. Vācu strādnieku rakstura struktūras dziḷāka analīze atklāj šā fenomena vienu - protams, ne vienīgo - cēloni. Daudziem vācu strādniekiem piemita personības tips, ko esam raksturojuši kā autoritāru. Viņi izjuta dziḷi iesakņojušos respektu pret vispāratzītu autoritāti un ilgojās pēc tās. Sociālisma uzsvars uz individuālu neatkarību pretēji autoritātei, uz solidaritāti pretēji indivīda izolācijai nebija gluži tas, ko šie ḷaudis vēlējās, jo to noteica vinu personības struktūra. Radikālo partiju vadoṇu ḳ̣ūda bija tā, ka viṇi pārvērtēja savu organizāciju ietekmi - viṇi redzēja ideju izplatîbu, bet neñēma vērā to reālo ietekmi.

Cita aina paveras protestantisma un kalvinisma doktrīnu analīzē. Tā parādīja, ka šīs idejas bija varens spēks jaunās religiijas piekritēju vidē, jo tās atbilda šo ḷaužu - ideju adresātu vajadzībām, viṇiem raksturīgajām bailēm un trauksmei. Citiem vārdiem sakot, idejas var kḷūt varens spēks, bet tikai tādā mērā, kādā tās kalpo kā atbilde uz noteikta sociālā rakstura pārstāvju specifiskām cilvēciskām vajadzībām.

Cilvēka rakstura struktūra nosaka ne tikai viņa domas un jūtas, bet arī viņa rīcību. Šì atklājuma nopelns pieder Freidam, pat ja viņa teorētiskais pamatojums nav gluži pareizs. To, kā cilvēka rakstura valdošās tendences 
determinē viņa darbỉbas, mēs uzskatāmi redzam neirotiķu uzvedībā. Viegli saprast, ka namu logu vai ietves bruğa akmeņu skaitī̌sana ir darbība, kas sakṇojas kompulsīva rakstura noteiktās dziṇās. Turpretī normāla cilvēka darbības šķietami nosaka tikai racionāli apsvērumi un reālas vajadzības. Tomēr, izmantojot psihoanalīzes piedāvātos jaunos novērošanas instrumentus, mēs varam konstatēt, ka tā dēvêto „racionālo uzvedību” lielā mērā determinē rakstura struktūra. Šîs atziñas ilustrāciju mēs redzējām mūsu diskusijā par darba nozīmi mūsdienu cilvēka dzīvē. Mēs redzējām, ka intensīvas alkas pēc nemitīgas darbošanās sakṇojas trauksmē un vientulībā. Šāda kompulsīva attieksme pret darbu atškiras no attieksmes pret darbu citās kultūrās, kur cilvēki strādāja, ciktāl tas bija vajadzīgs, bet neizjuta savā raksturā ietverto papildu spēku ietekmi. Mūsdienās visiem normāliem cilvēkiem piemît vienlīdz liela darba dziṇa, turklāt intensīva strādāšana ir nepieciešama, lai vispār izdzīvotu, tāpēc ir viegli nepamanīt šīs iezīmes iracionālo komponenti.

Tagad mums jājautā, kā raksturs funkcionāli kalpo indivīdam un sabiedrībai. Pirmajā gadījumāa atbilde ir vienkārša. Ja indivīda raksturs vairāk vai mazāk cieši atbilst sociālajam raksturam, tad viņa personības valdošās dziṇas mudina viṇu darìt to, kas nepieciešams un vēlams viṇa kultūras specifiskajos sociālajos apstākḷos. Teiksim, ja viņam piemīt kaislīga dziņa taupìt

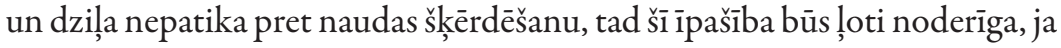
viņš ir sîktirgotājs, kuram jābūt taupịgam, lai izdzīvotu. Rakstura īpašībām lỉdztekus ekonomiskajai funkcijai - piemīt ne mazāk svarīgā psiholoǵiskā funkcija. Cilvēks, kuram taupišana ir vēlme, kas izriet no viņa personības rakstura, gūst arī dzịlu psihologisku apmierinājumu, ja vinam dota iespēja rîkoties atbilstoši iekšějai vajadzībai, proti, taupot viņš ne tikai gūst praktisku labumu, bet arī izjūt psiholog̣isku apmierinājumu. Par to viegli pārliecināties, vērojot, piemēram, iepērkamies tirgū sievieti no zemā vidusslānna: ietaupot divus centus, viña jūtas tikpat laimīga kā atškirīịa rakstura cilvēks, kas bauda kādu juteklisku tīksmi. Psiholoǵiskais apmierinājums iestājas ne vien tad, kad cilvēks rīkojas saskaņā ar sava rakstura prasībām, bet arī tad, kad viņ̧̌ lasa vai dzird domas, kas vinamam tuvas tā paša iemesla dẹlı. Autoritāru raksturu dziḷi iespaido ideolog̣ija, kas apraksta dabu kā varenu spēku, kam jāpakḷaujas, vai runa, kas satur sadistiskus politisko notikumu aprakstus; lasī̌sanas vai klausǐšanās norise sniedz viņam psiholog̣isku apmierinājumu. Tātad var secināt, ka normālam cilvēkam viņa rakstura subjektīvā funkcija ir mudināt 
rīkoties atbilstoši praktiskai vajadzībai un vienlaikus sniegt psihologisku apmierinājumu par viña rīcību.

Ja gribam aplūkot sociālā rakstura funkciju sociālajā procesā, tad mums jāsāk ar to pašu apgalvojumu, kas tika izteikts par sociālā rakstura funkciju indivīda dzìvē: pielāgojoties sociālajiem apstākḷiem, cilvēks attīsta tās rakstura iezīmes, kuras liek vinam gribēt rīkoties tā, kā vajag rīkoties. Ja noteiktā sabiedrībā vairuma cilvēku raksturs - proti, sociālais raksturs - ir pielāgots objektīvajiem uzdevumiem, kas indivīdam jāveic šajā sabiedrībā, tad ḷaužu energíija ievirzās tādā gultnē, kas to pārvērš šās sabiedrības funkcionēšanai nepieciešamā, produktīvā spēkā. Apskatīsim vēlreiz piemēru ar darbu. Mūsdienu industriālā sistēma prasa, lai lielākā dạ̦a mūsu enerǵijas tiktu ievirzīta darba gultnē. Ja cilvēki strādātu, vien ārēju vajadzību spiesti, tad veidotos milzīga plaisa starp vajadzību un vēlēšanos strādāt un šì plaisa mazinātu darba efektivitāti. Taču, pateicoties rakstura dinamiskai adaptācijai sociālām prasībām, cilvēka enerğija iemanto tādas formas, kas mudina rīkoties atbilstoši noteiktām ekonomiskām vajadzībām. Tātad mūsdienu cilvēks tai vietā, lai justos spiests smagi strādāt, l̦aujas tai iekšējai darba dziṇai, kuras psihologisko nozīmi mēs centāmies analizēt. Tai vietā, lai klausītu atklātai autoritātei, cilvēks ir izveidojis iekšēju autoritāti - sirdsapziṇu un pienākumu, kas viṇu kontrolē daudz efektīvāk nekā to spētu jebkāda ārēja autoritāte. Citiem vārdiem sakot, sociālais raksturs internalizē ārējās vajadzības un tādējādi mobilizē cilvēka enerğiju uzdevumiem, ko izvirza noteikta ekonomiska un sabiedriska sistēma.

Mēs jau redzējām, ka, tiklīdz rakstura struktūrā ir attīstījušās noteiktas vajadzības, tā jebkura uzvedība, kas atbilst šīm vajadzībām, sniedz vienlaikus psihologisku apmierinājumu un praktisku labumu no materiālā izdevīguma skatpunkta. Kamēr vien sabiedrība sniedz indivīdam šos abus apmierinājumus vienlaicīgi, mēs redzam situāciju, kurā psihologiiskie spēki cementē sociālo struktūru. Tomēr agri vai vēlu rodas neatbilstîba. Tradicionālā rakstura struktūra turpina pastāvēt jaunos saimnieciskos apstākḷos, kuros agrākās rakstura īpašỉbas vairs nav noderīgas. Cilvēks tiecas rīkoties saskaņā ar savu rakstura struktūru, bet jaunajos apstākḷ̆os vai nu šì darbošanās kḷūst par šḳērsli viṇa ekonomisko mērķu sasniegšanai, vai arī viņam nerodas gana daudz iespēju rīkoties atbilstoši savai „iedabai”. Tipisks piemērs ir agrākās vidusškiras rakstura struktūra - īpaši valstīs ar striktu kārtu hierarhiju, piemēram, 
Vācijā. Agrākie vidusslān, tikumi - pieticība, taupīgums, piesardzība, aizdomīgums - mūsdienu darījumu pasaulē kḷūst arvien nevērtīgāki salīdzinājumā ar jaunajām īpašỉbām, piemēram, iniciatīvu, gatavību riskēt, agresivitāti u. tml. Pat ja vecie tikumi laiku pa laikam noder - teiksim, vadot nelielu veikaliṇu, - tomēr mazās uzṇēmējdarbības iespējas ir tiktāl sašaurinātas, ka tikai daži vecā vidusslān,a dēli spēj veiksmīgi ,izmantot” personiskās rakstura īpašỉbas savā ekonomiskajā darbībā. Audzināšana viņos attīstija tādas rakstura iezīmes, kas savulaik bija pielāgotas vinuu sociālā slāņa situācijai, taču ekonomiskā attīstība noritēja straujāk nekā rakstura attīstība. Ekonomiskās un psiholog̣iskās evolūcijas ātruma atšķirība radīja situāciju, kurā ierastās ekonomiskā darbošanās vairs nespēja apmierināt psihologiiskās vajadzības. Tomēr šīs vajadzības joprojām pastāvēja un tiecās rast apmierinājumu kādā citā sfērā. Zemajam vidusslānim tipiskie šauri egoistiskie centieni pēc personiska pārākuma no individuālās jomas pārgāja uz valstisko. Arī sadistiskās dziņas, kas iepriekš tika izmantotas privātās konkurences cīṇā, daļēji pārvirzijjās uz sociālo un politisko jomu un dal̦ēji intensificējās frustrācijas dẹḷ. Atsvabinājušās no ierobežojošiem faktoriem, tās tiecās rast apmierinājumu politiskas vajāšanas aktos un karā. Tā psiholoǵiskie spēki, saliedējušies ar visas tracinošās situācijas izraisīto aizvainojumu un dusmām, tai vietā, lai nostiprinātu pastāvošo sabiedrisko kārtību, pārtop dinamītā, ko izmanto sociālās grupas, kas vēlas sagraut demokrātiskas sabiedrības tradicionālo politisko un ekonomisko struktūru.

Mēs līdz šim nerunājām par audzināšanas procesa lomu sociālā rakstura veidošanā. Daudzi psihologi uzskata, ka audzināšanas metodes agrīnās bērnības posmā un apmācības tehnika vēlākās skološanas gaitā ir noteikta rakstura attīstības cēlonis, tāpēc būtu lietderīgi šai sakarā izteikt dažas piezīmes. Vispirms vajadzētu noskaidrot, ko tieši mēs saprotam ar audzināšanu. To var definēt dažādi, bet paraudzīsimies uz to no sociālā procesa skatpunkta. Audzināšanas sabiedriskā funkcija ir sagatavot cilvēku tai lomai, ko viňš vēlākajos dzīves posmos spēlēs sabiedrībā, proti, veidot individuālo raksturu tā, lai tas tuvinātos sociālajam raksturam un cilvēka vēlmes sakristu ar viņa sociālās lomas vajadzībām. Šì funkcija determinē ikvienas sabiedrības audzināšanas sistēmu. Tātad mēs nevaram izskaidrot sabiedrības vai tās locekḷu personības struktūru, vērtējot audzināšanas procesu, toties mēs varam izskaidrot audzināšanas sistēmu, ņemot vērā vajadzības, ko nosaka 
zināmas sabiedrības sociālā un ekonomiskā struktūra. Tomēr audzināšanas metodēm ir ārkārtīgi liela nozīme, ciktāl tās uzlūko kā mehānismu, ar kura palīdzību indivīdus ielāgo noteiktā formā. Tās var uzskatīt par līdzekli sociālo prasību transformēšanai personiskās rakstura īpašỉbās. Audzināšanas tehnikas nav konkrēta sociālā rakstura cēlonis, tomēr konstituē vienu no mehānismiem, kas piedalās rakstura veidošanā. Šajā kontekstā audzināšanas metožu pārzināšana un izpratne ir svarīgs faktors funkcionējošas sabiedrības kopējā analīzē.

Nupat sacītais attiecas arī uz vispārējā audzināšanas procesa vienu atsevišķ sustāvdal̦u, proti, ğimeni. Freids parādīja, ka bērna agrīnai pieredzei ir izšķiroša ietekme uz viņa rakstura struktūras veidošanos. Ja tas ir tiesa, tad kā saprast apgalvojumu, ka bērns, kuram - vismaz mūsu kultūrā - ir l,oti maza saskare ar sabiedrisko dzīvi, tomēr tiek sabiedrības veidots? Atbilde ir šāda: vecāki (neņemot vērā atsevišķas individuālas variācijas) ne tikai izmanto tās sabiedrības, kurā viṇi dzīvo, audzināšanas paraugus, bet arī savā personā reprezentē noteiktas sabiedrības vai tās slān,a sociālo raksturu. Viṇi pārnes uz bērnu to, ko var nosaukt par sabiedrības psiholog̣isko gaisotni jeb garu; būtībā viṇi ir šā gara pārstāvji. Tādējādi gimeni var uzskatīt par sabiedrības psibologisko aǵentu.

Izsakot apgalvojumu, ka sociālo raksturu veido noteiktas sabiedrības eksistences mods, es gribētu lasītājam atgādināt to, kas grāmatas pirmajā nodaḷā bija teikts par dinamiskās adaptācijas problēmu. Lai gan ir tiesa, ka cilvēku veido vajadzības, kas izriet no sabiedrības ekonomiskās un sociālās struktūras, tomēr viņa pielāgošanās nav bezgalīga. Jāṇem vērā ne tikai cilvēka fiziolog̣iskās vajadzības, kas prasa apmierinājumu, bet arī viņam piemītošās psiholoǵiskās īpašỉbas, ko tāpat nepieciešams apmierināt un kas frustrācijas gadījumā izraisa noteiktas reakcijas. Kas tās par īpašībām? Šķiet, nozīmīgākā ir tieksme augt, attīstīties un realizēt potenciālu, ko cilvēks uzkrājis vēstures gaitā, piemēram, radošas un kritiskas domāšanas spēju vai izsmalcināta jutekliska baudījuma spēju. Katrai no šīm spējām piemīt savs dinamisms. Kolīdz tās attīstījušās evolūcijas procesā, tā tiecas izpausties. Šo tieksmi var apspiest un frustrēt, taču apspiešana izraisa jaunas reakcijas - īpaši destruktīvu un simbiotisku dziṇu veidošanos. Šì vispārējā izaugsmes tieksme (kas ir identiskās biolog̣iskās tieksmes psiholog̣isks ekvivalents) izraisa tādus specifiskus centienus kā, piemēram, brīvības alkas vai naidu pret apspiestību, 
jo brīvība ir jebkuras izaugsmes fundamentāls nosacījums. Un atkal, brīvības alkas var apspiest un tās var izgaist no cilvēka apziņas, taču pat šādā gadījumā tās turpina pastāvēt potenciālā formā, apliecinot savu esību apzinātā vai neapzinātā naidā, kas vienmēr pavada šādu apspiešanu.

Mēs varam pamatoti pien,emt, ka - kā jau sacīts iepriekš - centieni pēc taisnīguma un patiesības ir cilvēka dabas neatņemama iezìme, kaut arī to var apspiest un izkropḷot gluži tāpat kā tieksmi pēc brīvības. Šis pieñēmums saistās ar zināmām teorētiskām grūtībām. Škikietami vienkāršākais risinājums būtu meklēt pamatojumu kādā reliǵiskā vai filosofiskā doktrīnā, kas izskaidrotu šo centienu pastāvēšanu ar dabas likumiem vai ticību, ka cilvēks ir radīts pēc Dieva līdzỉbas. Tomēr šādi skaidrojumi nevar būt pamats mūsu argumentiem. Mūsuprāt, vienīgais ceḷ̌s, kā skaidrot šos centienus pēc taisnīguma un patiesības, ir visas cilvēces vēstures analīze sociālā un individuālā līmen̄i. Šajā analīzē mēs konstatējam, ka ikvienam, kurš ir vājš un bezspēcīgs, taisnīgums un patiesība ir spēcīgākie ieroči cīnā par brīvību un izaugsmi. Lielākā cilvēces dậa visā vēstures gaitā ir bijusi spiesta aizstāvēties pret varenākām grupām, kas to apspieda un ekspluatēja, bet arī katrs atsevišķais indivīds bērnībā pieredz šādu bezspēcìbas periodu. Mēs pieņemam, ka tieši šajā nevarības stāvoklī tad arī uzplaukst taisnīguma un patiesības izjūta, kas izvēršas par cilvēkam kā tādam piemītošu potenci. Tā mēs nonākam pie izpratnes, ka, lai gan rakstura attīstību veido dzives pamatnosacījumi un lai gan cilvēka iedabai nav biologiskas noteiksmes, tomèr cilvēka iedabai piemìt savs dinamisms, kas konstitue aktīvu faktoru sociālā procesa evolūcijā. Pat ja mēs vēl nevaram skaidri izteikt psihologiskos jēdzienos šā cilvēciskā dinamisma būtību, tomēr mums jāatzīst tā pastāvěšana. Cenšoties vairīties no maldīgām biologiskām un metafiziskām koncepcijām, mums nav jāpiel̦auj tikpat rupja kḷūda jeb sociolog̣isks relatīvisms, kas cilvēku uzlūko par marioneti, kura tiek raustīta aiz sociālo apstākḷu aukliṇām. Indivīda neatņemamās tiesības uz brīvību un laimi pamatojas viņam piemītošajās cilvēciskajās īpašībās - centienos dzīvot, paplašināt un izpaust potenciālu, kas vin̄ā attīstījies vēsturiskās evolūcijas procesā.

Te būtu svarīgi vēlreiz norādīt uz nozīmīgākajām atškirīībām starp Freida uzskatiem un to psihologiju, kas izklāstīta šajā grāmatā. Pirmā atšksirība ir detalizēti iztirzāta pirmajā nodaḷā, tāpēc šeit to atgādināšu vien īsos vārdos. Cilvēcisko iedabu mēs pamatā aplūkojam kā vēsturiski nosacītu, tomēr 
nemazinot biologisko faktoru nozīmi un neuzskatot, ka problēmas risinājums būtu kultūras un biologisko faktoru pretnostatī̌̌ana. Otrā atšķirīiba ir tā, ka Freids principā uzlūkoja cilvēku kā pašpietiekamu veselumu, slēgtu sistēmu, ko daba apveltījusi ar zināmām fiziolog̣iski nosacītām dziṇām, un rakstura attīstību interpretēja kā reakciju uz šo dziṇu apmierinājumiem un frustrācijām. Turpretī, mūsuprāt, fundamentāla pieeja cilvēka personībai ir izpratne par cilvēka attieksmi pret pasauli, citiem cilvēkiem, dabu un sevi pašu. Mēs uzskatām, ka cilvēks ir pirmām kārtām sociāla būtne un nevis, kā pieņem Freids, pirmāmkārtām pašpietiekama radība, kas tikai sekundāri izjūt vajadzību pēc citiem cilvēkiem, lai apmierinātu savas instinktīvās vajadzības. Šajā ziṇā mēs uzskatām, ka individuālā psihologija pamatā ir sociālā psihologija jeb, kā to definējis Salivens, starppersonālo attiecību psihologija. Psihologijas galvenā problēma ir indivīda noteikta veida attieksme pret pasauli, nevis atsevišķu instinktīvu vēlmju apmierinājums vai frustrācija. Izpratne par to, kas notiek ar cilvēka instinktīvajām vēlmēm, ir daḷa no vispārīgās problēmas, kas saistās ar cilvēka attieksmi pret pasauli un nevis cilvēka personības problēma. Tādējādi mūsu vēlmes un vajadzības, kas centrējas ap indivīda attieksmi pret citiem, piemēram, mīlestība, naids, maigums, simbioze, ir fundamentālas psiholog̣iskas parādības, turpretī Freida skatījumā tās tikai sekundāri izriet no instinktīvu vajadzību apmierinājuma vai frustrācijas.

Atšķirībai starp Freida biologisko un mūsu sociālo orientāciju ir īpaša nozīme saistībā ar rakstura veidošanās problēmām. Freids - uz viņa atklājumu pamata arī Abrahams, Džonss un citi - pieñēma, ka bērns izjūtu baudījumu tā sauktajās erogēnajās zonās (mutē un anālajā atverē) saistībā ar barošanas procesu un defekāciju un ka vai nu pārmērīgas stimulācijas un frustrācijas, vai konstitucionāli intensificēta jutīguma dēl, šīs erogēnās zonas saglabā savu libido raksturu vēlākajos mūža gados, kad normālas attīstības gaitā galveno lomu vajag iegūt ǵenitālajai zonai. Tiek pien,emts, ka šì fiksācija uz preǵenitālo līmeni noved pie sublimācijām un reakciju kompleksiem, kas kḷūst par dalı no rakstura struktūras. Tāa, piemēram, cilvēkam var piemist dziņa krāt naudu vai citus priekšmetus, jo viņš sublimē neapzināto vēlmi aizturēt izkārnījumus. Vai, teiksim, cilvēks sagaida, ka visus labumus viņam gādās citi, nevis centīsies tos iegūt ar paša pūlēm, jo izjūt neapzinātu vēlmi tapt barotam, kas sublimēta vēlmē saṇemt palīdzību, zināšanas utt. 
Freida novērojumi ir l̦oti svarīgi, bet viņš tos izskaidroja kḷūdaini. Viņš pareizi saskatìja šo „orālo” un ,anālo” rakstura iezīmju kaislīgo un iracionālo iedabu. Viņš arī redzēja, ka šādas vēlmes caurstrāvo visus personības aspektus - cilvēka seksuālo, emocionālo un intelektuālo dzīvi un ka tās iekrāso visu viņa darbošanos. Tomēr viņš nepareizi izprata kauzālās attiecības starp erogēnajām zonām un rakstura īpašībām, samainot vietām cēloṇus un sekas. Vēlme saņemt visu, ko sirds vēlas (mīlestību, aizstāvību, zināšanas, materiālas lietas) pasīvā veidā no ārēja avota, attīstās bērna raksturā kā reakcija uz viṇa pieredzi attiecībās ar citiem cilvēkiem. Ja šajā pieredzē bērna iekšèjā spēka apziņu vājina bailes, ja tiek paralizēta viṇa iniciatīva un pašpaḷāvība, ja attīstās un tiek apspiests naidīgums un ja vienlaikus viṇa tēvs vai māte piedāvā mīlestibu vai rūpes ar nosacījumu, ka bērns ir gatavs pakḷauties, tad šāds apstākḷu kopums rada attieksmi, kas paredz atteikšanos no aktīvas pasaules iekarošanas un visa enerğija tiek pievērsta ārējam avotam, no kura galu galā nāks visu vēlmju piepildijjums. Šì attieksme iemanto kaismīgu raksturu, jo tikai šādā ceḷā cilvēks var mēgināt realizēt savas iegribas. Cilvēki, kam piemīt šāda attieksme, bieži sapn,o vai fantazē par to, kā viņus baro, auklē utt., jo mute - vairāk nekā jebkurš cits ķermeņa orgāns - atbilst šās receptīvās attieksmes paušanai. Taču orālās izjūtas nav šās attieksmes cēlonis. Tās izsaka attieksmi pret pasauli ķermeņa valodā.

To pašu var teikt par „anālo” personu, kura uz savas īpašās pieredzes pamata ir vairāk atsvešināta no citiem nekā „orālā” persona un meklē drošỉbu, pārvēršot sevi pašpietiekamā sistēmā. Šāds cilvēks uztver mīlestību vai jebkuru citu ārpusēji vērstu attieksmi kā draudus savai drošībai. Tiesa, daudzos gadījumos šāda attieksme vispirms veidojas saistībā ar barošanu vai defekāciju, kas agrīnā vecumā ir bērna galvenās nodarbes un arī galvenā joma, kurā gūst izpausmi mīlestība vai apspiešana no vecāku puses un attiecīgi draudzīgums vai nepaklausība no bērna puses. Tomēr pārmērīga stimulācija un frustrācija saistībā ar erogēnām zonām pašas par sevi vēl neizraisa šādas attieksmes fiksāciju cilvēka raksturā. Lai gan saistībā ar barošanu un defekāciju bērns pārdzīvo zināmu juteklisku baudījumu, tomēr šai tīksmei nav nozīmīga loma rakstura attīstībā, ja vien tā nereprezentē - fiziskā līmenī attieksmi, kas sakņojas kopīgā rakstura struktūrā.

Ja bērns izjūt paļāvīgu ticību savas mātes beznosacījumu mīlestîbai, tad pēkšņai krūts barošanas pārtraukšanai nebūs nekāda drūma iespaida uz 
viņa turpmāko rakstura attīstību. Turpretī mazulis, kuram trūkst paḷāvības uz mātes mīlestību, iemantos „orālas” rakstura iezīmes pat tad, ja barošanas process noritēs bez kādiem seviškịiem traucējumiem. „Orālās” un „anālās” fantāzijas vai fiziskās izjūtas vēlākajos gados ir svarīgas ne saistībā ar izraisīto baudījumu vai šā baudījuma mistisku sublimāciju, bet tikai saistībā ar noteikta veida attieksmi pret pasauli, kas ir to pamatā un ko tās izpauž.

Vienīgi no šāda skatpunkta Freida atklājumiem cilvēka rakstura attīstības jomā var būt nozīme sociālajā psihologijāa Kamēr mēs pien,emam, ka, teiksim, anālo raksturu tipisku Eiropas zemākā vidusslān,a pārstāvjiem izraisa zināma agrīna pieredze saistībā ar defekāciju, tikmēr mūsu rīcībā nav nekādu datu, kas l̦autu saprast, kāpēc šim sabiedrības slānim veidojas tieši anāls sociālais raksturs. Turpretī, ja mēs to uzlūkojam kā tādas attiecības ar citiem ḷaudīm, kas sakņojas rakstura struktūrā un izriet no pieredzes ārpasaulē, tad gūstam iespēju gūt izpratni par to, kāpēc zemā vidusslāņa pārstāvju dzīvesveids, uzskatu šaurība, izolācija un naidīgums dod savu ieguldījumu tieši šādas rakstura struktūras izveidē. ${ }^{61}$

Trešā svarīgā atšķirība ir cieši saistīta ar abām iepriekšējām. Freidam viņa orientācijas uz instinktiem un dziḷās pārliecības par cilvēka dabas samaitātîbu dēḷ - ir slieksme interpretēt visus „ideālos” motīvus cilvēkā kā kaut kā „maziska” sekas; šai ziṇā tipisks ir viņa skaidrojums par taisnīguma izjūtu kā izrietošu no bērna sākotnējās skaudības pret jebkuru cilvēku, kuram pieder vairāk nekā viṇam. Kā jau iepriekš norādīts, mēs uzskatām, ka ideāli, piemēram, patiesība, taisnīgums vai brīvība par spīti tam, ka bieži izrādās vien tukši vārdi vai racionalizācijas, var būt patiesi centieni un ka kḷūdaina ir tā analīze, kas šos centienus neaplūko kā dinamiskus faktorus. Šie ideāli nav metafiziski, bet sakņojas cilvēka dzīves apstākḷos un var tikt analizēti no šāda skatpunkta. Šādas analīzes ceḷā nevajadzētu stāties bailēm iekrist metafiziskos prātojumos vai ideālistiskās koncepcijās. Psihologiijas kā empīriskas zinātnes uzdevums ir pētīt ideālu radīto motivāciju un ar tiem saistītās morāles problēmas un tādējādi atsvabināt mūsu domāšanu par šīm lietām no neempīriskiem un metafiziskiem elementiem, kas aizmiglo šo jautājumu būtîbu to tradicionālā traktējumā.

Visbeidzot mums jāmin vēl viena atšksirība. Tā saistīta ar vajadzību un pārpilnības psihologisko parādību diferenciāciju. Cilvēciskās esības primitīvais līmenis ir vajadzību līmenis. Pastāv imperatīvas vajadzības, kam jātop 
apmierinātām pirms visa pārējā. Vien tad, ja cilvēkam atliek laiks un enerğija pēc primāro vajadzību apmierināšanas, var attīstīties kultūra un līdz ar to arì centieni, kas attiecināmi uz pārpilnības parādībām. Brīvi (jeb spontāni) akti vienmēr ir pārpilnības fenomeni. Freida psihologija ir vajadzību psihologija. Viņš definē baudījumu kā apmierinājumu, ko rada sāpīgas spriedzes novēršana. Pārpilnības parādībām, piemēram, mīlestībai un maigumam, faktiski nav nekādas lomas viṇa sistēmā. Freids ne vien ignorē šādas parādības, bet arī šauri izprot parādību, kam velta tik daudz uzmanības, proti, seksualitāti. Saskañā ar savu vispārīgo baudas definīciju Freids saredz seksualitātē vien fiziologiskas nepieciešamības elementu, bet seksuālā apmierinājumā - sāpīga sasprindzinājuma atslābumu. Viṇa psihologiijā nav vietas dzimumdziṇai kā pārpilnības parādībai un seksuālai tīksmei kā spontānas līksmes izpausmei, kuras būtība nav negatīva spriedzes novēršana.

Kāds interpretācijas princips šajā grāmatā ticis izmantots kultūras cilvēciskā pamata izpratnei ? Pirms sniegt atbildi uz šo jautājumu, būtu derīgi atgādināt galvenos interpretāciju virzienus, kas atškłiras no mūsējā.

I. „Psiholoğiskā” pieeja, kas raksturīga Freida domāšanai. Tā paredz, ka kultūras parādības sakṇojas psiholoğiskos faktoros, kas izriet no instinktīvām dzin̄ām, ko sabiedrība ietekmē tikai ar stiprākas vai vājākas apspiešanas līdzekḷiem. Freida sekotāji, kas pārṇēmuši šā veida interpretāciju, izskaidro kapitālismu kā anāla erotisma iznākumu, bet agrīnās kristietības attīstību kā rezultātu ambivalentai attieksmei pret tēva tēlu. ${ }^{72}$

2. „Ekonomiskā” pieeja, kas prezentēta Marksa vēstures interpretācijas nepareizā lietojumā. Saskaṇā ar šo pieeju kultūras parādību, piemēram, religijas un politisko ideju, cēlonis ir subjektīvas ekonomiskas intereses. No šāda pseidomarksistiska skatpunkta ${ }^{83}$ varētu censties skaidrot protestantismu kā atbildi uz buržuāzijas ekonomiskajām vajadzībām - un neko vairāk.

3. Visbeidzot, „ideālistiskā” pieeja, ko reprezentē Maksa Vēbera analīze „Protestantiskā ētika un kapitālisma gars”. Vēbers apgalvo, ka jaunās reliǵiskās idejas ir sekmējušas jauna tipa ekonomiskās uzvedības un jauna kultūras gara attīstību, tomēr uzsver, ka šì uzvedỉba nav tikai un vienīgi reliǵisko doktrīnu nosacīta.

Pretēji šiem skaidrojumiem mēs pieņemam, ka ideolog̣ijas un kultūra vispār sakn,ojas sociālajā raksturā, ka pašu sociālo raksturu veido noteiktas sabiedrības esības veids un ka valdošās rakstura iezīmes savukārt izvēršas 
produktīvā spēkā - sociālā procesa veidotājā. Saistībā ar protestantiskā gara un kapitālisma problēmu es centos parādīt, ka viduslaiku sabiedrības sabrukums apdraudēja vidusslāni, ka šie draudi izraisīja bezspēcīgas izolācijas un šaubu izjūtas, ka šī psihologiskā pārmaiņa sekmēja Lutera un Kalvina mācību popularitāti, ka šîs doktrīnas intensificēja un stabilizēja izmaiñas rakstura struktūrā un ka šādi veidojušās rakstura iezīmes izvērtās par produktīvu spēku, attīstot kapitālismu, kas savukārt veidojās ekonomisku un politisku pārmaiṇu gaitā.

Tas pats skaidrojuma princips tika izmantots attieksmē pret fašismu. Vidusšķiras zemākie slāṇi reaǵēja uz noteiktām ekonomiskām pārmaiṇām, piemēram, monopolu varas pieaugumu un pēckara inflāciju, intensificējot noteiktas rakstura iezīmes, tostarp sadistiskas un mazohistiskas tieksmes. Šìs iezīmes vēl vairāk nostiprināja nacisma ideolog̣ija, un jaunās rakstura īpašỉbas kḷuva par varenu ieroci vācu imperiālisma ekspansijas atbalstam. Abos gadījumos mēs redzam, ka apstāklı,os, kad jaunas ekonomiskas tendences apdraud kāda sabiedrības slān,a labbūtību, tā uz šiem draudiem reaǵē psihologiski un ideologiski un ka šìs reakcijas izraisītās psihologiskās pārmaiņas sekmē tālāku ekonomisko spēku attīstỉbu, pat ja šie spēki pretdarbojas noteiktā slāņa ekonomiskajām interesēm. Mēs redzam, ka ekonomiskie, psihologiskie un ideoloǵiskie spēki darbojas šādi: cilvēks reagēe uz izmaiṇām ārējā situācijā tādējādi, ka izmaina pats sevi, un šie psiholog̣iskie faktori palīdz veidot ekonomisko un sociālo procesu. Ekonomiskie spēki ir iedarbīgi, bet tie jāizprot nevis kā psihologiskas motivācijas, bet gan kā objektīvi nosacìjumi. Psihologiskie spēki ir iedarbīgi, bet jāsaprot, ka tie paši ir vēsturisko apstākḷu nosacīti. Idejas ir iedarbīgas, bet jāsaprot, ka tās sakṇojas noteiktas sociālās grupas locekḷu vispārīgā rakstura struktūrā. Tomēr, par spīti ekonomisko, psihologisko un ideoloǵisko spēku savstarpējai atkarībai katram no tiem piemīt sava autonoma patstāvība. Īpaši tas redzams ekonomiskajā attīstībā, kas, būdama atkarīga no objektīviem faktoriem, piemēram, dabas resursu pieejamības, tehnologijām vai ǵeogrāfiskiem apstākḷiem, norisinās pēc saviem iekšējiem likumiem. Mēs norādījām, ka tas pats attiecas uz psihologiskajiem spēkiem: tos ietekmē ārējie dzīves apstākḷi, taču tiem piemīt savs iekšējs dinamisms, proti, tie pauž cilvēciskas vajadzības, kas, lai gan ir ietekmējamas, nevar tikt izskaustas. Ideolog̣ijas jomā mēs redzam līdzīgu autonomiju, kas sakņojas log̣ikas likumos un vēstures gaitā iemantotā izziṇas tradīcijā. 
Mēs varam formulēt šo principu arī saistībā ar sociālo raksturu. Sociālais raksturs veidojas kā cilvēka iedabas dinamiska adaptācija sabiedrības struktūrai. Sociālo apstākḷ maiņa sekmē izmaiņas sociālajā raksturā, proti, gūst izpausmi jaunās vajadzībās un nemieros. Šīs jaunās vajadzības rosina jaunas idejas un vienlaikus gatavo augsni šo ideju uztverei cilvēku prātos. Savukārt jaunas idejas tiecas stabilizēt un intensificēt jauno sociālo raksturu un nosacìt cilvēka rīcību. Citiem vārdiem sakot, sociālie apstākḷi ar rakstura starpniecību ietekmē ideologiskās parādības, bet raksturu veido ne pasīva pielāgošanās sociāliem apstākḷiem, bet gan dinamiska adaptācija uz to elementu pamata, kas ir vai nu biologiski iekodēti cilvēka iedabā, vai arī iemantoti vēsturiskās evolūcijas gaitā.

\section{Vēres}

I Saskaņā ar Annas Hartohas sniegtajiem datiem (no M. Gay, A. Hartoch un L. B. Murphy topošās grāmatas par Sāras Lorensas sākumskolas audzēkṇu gadījumu studijām) Roršaha pētijjumi par trīs līdz piecus gadus veciem bērniem parādīja, ka mēğinājums saglabāt savu spontanitāti ir galvenais cēlonis konfliktam starp bērniem un autoritatīiem pieaugušajiem.

2 Kā spilgtu ilustrāciju draudzīguma komercializācijai es gribētu minēt reportāžu „Hovarda Džonsona restorāni” žurnālā Fortune’s (1940. g. septembris, 96. lpp.). Džonsons nolīgst „klientus”, kuri apmeklē viņa restorānus, lai kontrolētu personāla darbu. „Visi ēdieni tiek gatavoti atbilstoši uzņēmuma vadības apstiprinātām standarta receptēm, tāpēc inspektors zina, cik lielai jābūt steika porcijai un kā jāgaršo dārzeņiem. Viņš arī zina, cik ilgā laikā pusdienām jābūt pasniegtām un cik draudzīgai ir jābūt oficiantes attieksmei pret apmeklètājiem."

3 Šìs problēmas analīzi kopumā sk.: Robert S. Lynd Knowledge for What? Princeton University Press, 1939. Tās filosofiskie aspekti aplūkoti: Horkheimer M. Zum Rationalismusstreit in der gegenwärtigen Philosophie. Zeitschrift für Sozialforschung, Vol. 3, 1934, F. Alcan, Paris.

4 Sal.: Max Otto. The Human Enterprise. T. S. Croft, New York, 1940, IV un V nodalia.

5 Šì jautājuma analīze noved pie l̦oti svarīga secinājuma, ko es gribētu vismaz pieminēt: dinamiskā psiholog̣ija var sekmēt ētisku problēmu risināšanu. Psihologi šai ziņā varēs palīdzēt vien tad, ja atskārtīs morāles problēmu nozīmi cilvēka personības izpratnē. Jebkura - arī Freida - psiholog̣ija, kas uzlūko morāles problēmas tikai no tîksmes principa skatpunkta, nespēj izskaidrot l̦oti svarīgu personības aspektu un tādējādi paver ceḷu dogmatiskām, neempīriskām morāles doktrīnām. Šajā grāmatā ietvertā sevis mīlestības, mazohistiskas ziedošanās un ideālu analīze ilustrē psiholoğijas un êtikas problēmas, kas pelnījušas dzị̣āku izvērsumu. 
6 F. Aleksanders ir mēginājis sniegt jaunu Freida atklājumu interpretāciju, kas zināmā mērā līdzinās mūsu nostājai. (Sk.: F. Alexander. The Influence of Psychological Factors upon Gastro-Intestinal Disturbances. Psychoanalytic Quarterly, Vol. XV, 1934.) Taču, lai gan viņa uzskati ir attīstījušies tālāk nekā Freidam, viņam nav izdevies pārvarēt biolog̣isko orientāciju un pilnībā apzināt interpersonālās attiecības kā šo „preǵenitālo” dziṇu pamatu un būtību.

7 Šì metode pilnīgāk aplūkota: Fromm E. The Dogma of Christ. Holt, Rinehart and Winston, Inc., New York, 1963.

8 Es dēvēju šo uzskatu par pseidomarksistisku, jo tas interpretē Marksa teoriju kā tādu, kas apgalvo, ka vēsturi determinē ekonomiski motīvi materiālu labumu nozīmē, nevis kā tos izprata pats Markss, proti, kā objektīvus apstākḷus, kas var novest pie dažādām ekonomiskām attieksmēm - intensīvas alkas pēc materiālas bagātības ir tikai viena no tām. (Par to bija runa I. nodal̦ā.) Šìs problēmas sīkāku izklāstu sk.: Fromm E. Über Methode und Aufgabe einer Analytischen Sozialpsychologie. Zeitschrift für Sozialforschung, Vol. I, 1932, p. 28 ff. Sk. arī: Robert S. Lynds Knowledge for What? Princeton: Princeton University Press, 1939. Chap. II. 


\section{Igors Šuvajevs}

\section{Noslēgums jeb Fromma aktualitāte Latvijā}

Lai runātu par Ēriha Fromma aktualitāti mūsdienās, nepieciešams fiksēt viņa novietojumu idejiski garīgo meklējumu kontekstā, tad iespējams precīzāk arī uzrādīit viņa aktualitāti Latvijā. Taču tieši š̃ novietojuma noteikšana nemaz nav tik viegla. Dažkārt viña veikums tiek iekḷauts humānistiskajā psihologijiā, pašam Frommam tas gan nav pieņemams, lai gan dažkārt viņ̧̌ uzstājas kā psihologs. Reizumis tiek runāts par viņa socioloğisko psihoanalīzi, pats Fromms gan raksta par analītisko sociālpsihologiju, kuras uzmanības lokā lielākoties ir sabiedrības raksturs un raksturorientācijas. Fromms tiek dēvēts par psihoanalīikịi, un tas ir pareizi, tomēr viņ̧̌̌ piedāvā psihoanalīzes variāciju, ko dēvē par neopsihoanalīzi jeb neoanalīzi. Turklāt Fromms uzsver psihoanalīzes transterapeitisko nozīmi, vienlaikus izstrādājot arī politisko psihoanalīzi. Fromms tiek saistīts arī ar filosofisko antropoloǵiju, viņš pat ieskicē visaptverošas filosofiskās antropologijas problemātiku. Tomēr viṇa uzmanības lokā galvenokārt ir mūsdienu (tagadējā) cilvēka stāvoklis, īpaši izceļot cilvēka būšanu, labbūtību. Saistībā ar labbūtību jeb labbūšanu Fromms raksta par mākslu mīlēt, iespēšanu būt, uzrādot apliecināšanas vērtas vērtības. Fromma devums tiek dēvēts par abstrakto humānismu, kaut gan viṇš pats raksta par sociālistisko, t.i., radikālo jeb revolucionāro humānismu. Šādi viņš iedomājas liekam pamatus jaunai humānistiskai êtikai. Fromms raksta par relig̣iju, un tā ievijas arī vina izstrādnēs. Izsakoties îsāk - Fromms ir daudzveidīgs. Un šì kolektīvā monogrāfija ir mēgeinājums iezīmēt dažus aspektus viņa idejiski filosofiskajā portretējumā. 
Tomēr kopsavilkumā vēlreiz der norādīt uz Fromma aktualitāti kopumā un aktualitāti Latvijā. Turklāt aktualitāte Latvijā vienlaikus ir arī aktualitāte pasaulē (un otrādi), ja acīmredzot neskaita vienu punktu. Un šis punkts ir Fromma teksti latviešu valodā. Viņa darbu tulkošana ir pašos aizsākumos. Filosofisku, psihoanalītisku tekstu tulkošana nepavisam nav vienkārša pārlikšana kādā valodā, tulkojums paredz konceptuālu, jēdzienisku un terminolog̣isku darbu. Un šādā darbā dažkārt atklājas iezīmes, kas nav pamanāmas oriǵginālvalodā. Tā kā arī Fromma tekstu tulkošana (un izdošana) latviešu valodā var norādīt uz Fromma aktualitāti mūsdienās kopumā.

Fromma aktualitāte atklājas kā viņa psihoanalīze, pareizāk sakot, tās variācija. Principā piecdesmitajos gados noslēdzas Fromma īstenotā psihoanalīzes revīzija. Tomēr izvērstu psihoanalīzes revīziju un izskaidrotu re-vīziju pats Fromms nepiedāvā, kaut arī grasās to darìt. Tāpēc patlaban to var tikai rekonstruēt. Gluži tāpat kā vēlreiz no jauna ir nepieciešams pārskatīt Fromma attiecības ar Freidu. Vai viņa uzmanības lokā tiešām ir Freids vai arī amerikāniskais Freids? Cik lielā mērā Fromms jaunā terminologiskā valodā pārtulko jau Freida iezīmēto risinājumu? Fromma tekstuālajā korpusā par dziedināšanu un tās tehniku rodamas tikai piezīmes un daži apsvērumi. Tomēr Fromma psihoanalīze aizvien vēl tiek praktizēta. Tāpēc aktuāls ir arī jautājums par tās terapeitisko nozīmi. ${ }^{1}$

Fromms atsakās no psihoanalītiskās dziņas teorijas, tās vietā piedāvājot koncepciju par sabiedrības jeb sociālo raksturu. Cik lielā mērā tas ir ieguvums, bet cik lielā - šķietams ieguvums? Lai kāda arī būtu atbilde, Fromms joprojām ir aktuāls sabiedrības ( kā arī individuālās) harakterologijijas kontekstā. Var diskutēt par Fromma tipologiju vai vēsturiskajiem ekskursiem, tomēr nav noliedzama dažu ideju produktivitāte arī mūsdienās. Šīs raksturorientācijas ir šādas: receptīvā, ekspluatējošāan, uzkrājošā un mārketinga (tirgus) jeb patērējošā orientācija. Tām var būt kā pozitīvas, tā negatīvas izpausmes, un tās var pastāvēt līdzās cita citai. Tomēr mūsdienas raksturo patērējošāā orientācija savā neproduktīvajā variantā. Patērējošās raksturorientācijas tipa cilvēks pret visu izturas kā pret preci, kuras vērtību nosaka maiņas vērtība. Viņš ir sava veida pārdēvējs, kas pārdod arī pats sevi, tāpēc nav ieinteresēts savā pašbūtībā un nav arī uz to spējīgs. Viṇam svarīgi ir panākumi, iespēja apsteigt citus, viņš principā nekad nav pats, patērējošais laika gaitā kḷūst par tērēto. Šāds raksturs Fromma izpratnē nosaka kā indivīda, tā sabiedrības 
(kāda kopuma) izturēšanos, galu galā viņa izpratnē no šĩ rakstura ir atkarīga arī ideologija un kultūra. Kāds raksturtips pastāv Latvijā, Eiropā, pasaulēe Tas nav tikai retorisks jautājums, jo raksturs izvēršas domās, jūtās, darbībās. Turklāt Fromma raksturorientāciju koncepcijas izstrāde viņa garā tiek turpināta. ${ }^{2}$ Un runa nav tikai par indivīdu raksturiem, runa ir arī par raksturu sabiedrībā, kas nosaka tās virzību, dominējošo darbību kopumu.

Fromms speciāli pievēršas cilvēka destruktivitātes problemātikai, kas jo sevišķ aktuāla ir kḷuvusi pēdējā laikā (it īpaši saistībā ar Krieviju). ${ }^{3}$ Fromma skatījumā pastāv defensīvā agresija jeb labdabīgā, dzīvi apliecinošā agresivitāte un ļaunā agresija, kas izpaužas galvenokārt sadismā un nekrofilijā. Sadistisks indivīds ir mazdūšīgs un vājšs, viņš neuzdrošinās būt un to visu cenšas kompensēt ar kundzību pār citiem. Taču agresivitāte var ierakstīties arī sabiedrības jeb sociālajā raksturā. Un tādā gadījumā sabiedrībā uzrodas aizvien vairāk šādi sadistiski ievirzīti indivīdi. Savukārt nekrofilija izpaužas tieksmē pēc nedzīvā, mirušā, lietiskojamā. Nekrofilija izpaužas politikā un ekonomikā, tā neiet secen arī dabaszinātnēm. Viss tiek sadalīts, mehanizēts, padarīts par saskaitāmām vienībām, kuras tikpat mehāniski tiek kontrolētas. Esošais ir izejviela, ar kuru var darboties, skaitl̦i, ar kuriem var manipulēt. Savā ziņā vislabākais ir beigtais. Šai beigtā kultivēšanai, nedzīvā fascinējošajai aizrautībai Fromms pretstata biofiliju - dzīvā mīlěšanu, dzīvā apliecināšanu.

Fromms raksta par diviem eksistences un pieredzes modiem - būt (būšanu) un piederēt (piesavināšanu, īpašumošanu, dabūšanu). Būšana ir aktīva, produktība darbība (domāšana, mīlěšana), kas nav nekāds aktīvisms vai darbošanās. Savukārt piederēšana īstenībā ir pasivitāte, kurā dominē piederētgriba: lai piederētu mantas, slava, vērtības u. tml. un lai pats piederētu kaut kam lielākam, labākam, skaistākam u. tml. Piederēšana ietver to, ko latviski var izteikt ar vārdiem „pieder” un „piederēties”. ${ }^{4}$ Piederēšana iezīmē privatīvismu, kurā privātais dažkārt ir publiskais, t.i., publiski izrādāmais.

Piederēšana Fromma skatījumā ir sajūgta ar autoritatīvu reliǵiju, savukārt būšanā svarīgāka ir Dieva pieredzēšana. Un šādā pieredzē ir gūstama vienbūšana ar Dievu, proti, šādi iespējams nokḷūt stāvoklī, kurā cilvēks un Dievs kḷūst viens. Fromms pievēršas dažādām reliğiskajām tradīcijām. Viṇš norāda uz orientālajām tradīcijām un brīdina par to pārvēršanu spirituālās precēs mūsdienu patērējošajā pasaulē. No Tālo Austrumu mācībām viṇu īpaši saista dzenbudisms un joga. Taču arī Rietumu tradīcijā ir gūstamas 
svarīgas atziñas. Fromms īpaši uzsver profētisma un hasīdisma nozīmi. Savā ziṇā Fromms dzīvo ar hasīdisma tradīciju, jo daudzko no tās mācās. Un šajā ziņā viņa veikums Latvijā var atklāties reljefāk, jo arī šeit ir spēcīga hasīdisma tradīcija.

Fromms nav iedomājams bez filosofijas, var pat teikt, ka viņš ir filosofējošs psihoanalīitikis. Jau i939. gadā viņš publicē rakstu „Savtīgums un pašmīlestība", kurā pamato, ka egoisms nepavisam nav sevis mīlēšana, egoists nemīl sevi, jo vispār nespēj un neprot mīlēt vai labākajā gadījumā pieķeras sevis iedomātam tēlam. Šādi Fromms aktualizē jau Aristoteḷa izstrādāto pašmīlestības jeb pašdraudzības konceptu, ko Platons izstrādājis kā pašrūpes konceptu. Fromms atsaucas uz Huserlu, Heidegeru, Kantu, Spinozu un daudziem citiem filosofiem. Mūža nogalē viņu īpaši saista Meistars Ekharts. Taču savā ziṇā visu mūžu viņu pavada Markss. Fromma skatījumā Marksa izstrādājamais sociālisms ir profētiskā mesiānisma sekulāra izpausme. Viṇš gan vairāk atsaucas uz agrīno Marksu. Tāpēc patlaban jo īpaši svarīgi izprast un analizēt Fromma sociālismu, viṇa attieksmi pret dažādajiem marksisma variantiem un norisēm Padomju Savienībā, kas tiek dēvēta par Krieviju.

Tomēr viens Fromma izstrādņu aspekts ir ìpaši svarīgs, proti, dzīvotmāksla jeb māksla būt. ${ }^{5}$ Šàdi atklājas arī Fromma centieni parādīt psihoanalīzes transterapeitiskumu. Jau darbā „Cilvēks pats sev” (1947) Fromms norāda, ka ētika ir dzīvesmāksla, kurā cilvēks ir gan mākslinieks, gan savas mākslas priekšmets. Psihoanalīzes rosinātā pašiepazī̌sana, pašpieredzēšana, pašanalīze iekḷaujas dzīvesmākslā. Šāda dzīvesmāksla ietver dažādus vingrinājumus, no kuriem dažus Fromms aprāda, kā arī pašattīstību, pašbūšanu. Tomēr viņš neizstrādā sistemātisku dzīvesmākslu. Tāpēc tās veidošanā Fromma darbos var gūt vērtīgas ierosmes un atziņas. Ne velti viņ̧̌ pats atsaucas uz Meistaru Ekhartu: „Kā vispār var dzīvot, ja neesi apmācīts dzīvošanas un nomiršanas mākslā.” Un Fromms var lieti noderēt tās apguvē.

\section{Vēres}

I Diemžēl jau 2013. gadā notikušajā konferencē iezīmējās Latvijas psihoterapeitu, psihologu nespēja mūsdienīgi risināt šāda veida jautājumus. Tāpēc šajā kolektīvajā monogrāijā arī nav šādas psihoanalītiskajai dziedināšanai, psihoterapijai veltìtas sadaļas. Par 
psihoterapiju Latvijā, kaut arī ne vienmēr precīzi un piln̄̄gi, sk.: Dombrovsky A. History of the Development of Psychotherapy in Latvia. Vienna: S. Freud Private University, 2013.

2 Sk., piem.: Funk R. Ich und Wir. Psychoanalyse des postmodernen Menschen. München: dtv, 2005; Ders. Der entgrenzte Mensch. Gütersloh: Gütersloher Berlagshaus, 20II. Šeit Rainers Funks raksta par Es orientāciju.

3 Par filosofu dēvētais amerikāṇu psihologs Stīvens Pinkers nesen ir nācis klajā ar atzinuu par vardarbības mazināšanos vēstures gaitā (sk.: Pinker St. The better Angels of our Nature. Why Violence has declined. New York: Viking Press, 20II), taču viņš ir iemanījies pilnīgi apiet destruktivitātes, agresijas, vardarbības teorētisko izstrādņu aplūkošanu.

4 Acīmredzot, tikai pārtulkojot latviski Fromma darbu „To Have or to Be?”, būs iespējams runāt par terminologisku precizitāti Fromma (un ne tikai viņa) ideju izklāstā.

5 „Fromma paliekošās aktualitātes īstais iemesls ir dzīvotmākslas aktualitāte." (Sk.: Funks R. Eriha Fromma aktualitāte. Rīga: FSI, 2014, 26. lpp.) Sal.: Wolf U. Die Philosophie und die Frage nach dem guten Leben. Hamburg: Rowohlt, 1999, S. 83-87, 93, 97.

6 Fromm E. Gesamtausgabe. München: Deutsche Verlags-Anstalt, 1999, Bd. I2, S. 4 OI. 



\section{Fromma dzīvesgājums}

I900 23. martā ortodoksālā ebreju vīntirgotāja Naftala un Rozas Frommu gimenē Frankfurtē pie Mainas piedzimst Ērihs Pinhass Fromms

I9I8 Abitūrija un divu semestru jurisprudences studijas Frankfurtē, draudzība ar rabīnu Nehemiju Nobelu

I9ı Sociologijas, psihologijas un filosofijas studijas Heidelbergā. Talmūda apgūšana rabi Zālamana Baruha Rabinkova vadībā (līdz I926. g.)

1922 Promovēšanās filosofijā pie Alfrēda Vēbera ar darbu „Jūdaiskais likums"

1924 Iepazǐšanās ar Frīdu Reihmani un psihoanalīzi

I926 I6. jūnijā kāzas ar Frīdu Reihmani. Psihoanalīzes apguve pie Karla Laundauera Frankfurtē, novēršanās no ortodoksā jūdaisma, iepazīšanās ar Georgu Grodeku

1927 Pirmā publikācija psihoanalīzes jomā - „Sabats”

I928 Mācību analīzes kursa iziešana pie Hansa Zahsa

1929 Fromms ir Frankfurtes Dienvidvācu psihoanalīzes institūta līdzdibinātājs, psihoanalīzes apguve Hansa Zahsa vadībā Berlīnes Psihoanalīzes institūtā 
I930 Frankfurtes Sociālo pētījumu institūta līdzstrādnieks (pēc Maksa Horkheimera uzaicinājuma), psihoanalītiskās privātprakses uzsākšana Berlīnē

I93I Šķiršanās no sievas, plaušu tuberkulozes ārstēšana Davosā

1932 Topošās mācības iezīmēšana rakstā „Par analītiskās sociālpsihologijas metodi un uzdevumiem"

1933 Vieslekcijas Čikāgā, emigrācija, tēva nāve

1934 Pārcelšanās uz N̦ujorku, darbs N,ujorkas Kolumbijas universitātes Sociālo pētījumu institūtā. Tuvāka iepazīšanās ar Karenu Horneju un sadarbība ar Hariju Sallivenu

I936 Autoritārā rakstura problemātikas izstrāde Maksa Horkheimera izdotajā krājumā „Studijas par autoritāti un gimeni”

1938 Izstāšanās no Sociālo pētījumu institūta, pirmās publikācijas angḷu valodā

1940 Amerikāņu pavalstniecības iegūšana

I94I Monogrāfija „Bēgšana no brīvības”. Hornejas grupas atdalī̌̌anās no Nujorkas Psihoanalītiḳu biedrības

1943 Nošķiršanās no Hornejas grupas un Viljama Vaita institūta izveide N̦ujorkā

I944 24. jūlijā kāzas ar Henniju Gurlandi

I947 Grāmata „Cilvēks pats sev”, dzīvesmākslas un patērējošā rakstura koncepta izstrāde

I949 Pārcelšanās uz Mehiko

I95I Mehiko Nacionālās universitātes Medicīnas fakultātes ekstraordinārais profesors, psihoanalīzes mācību analīzes uzsākšana

1952 Sievas Hennijas nāve

I953 I8. decembrī kāzas ar Enisu Frīmani

I955 Grāmata „Veselā sabiedrība”, iestāšanās par komunitāro sociālismu

1956 Grāmata „Māksla mīlēt”. Meksikas Psihoanalīzes biedrības nodibināšana. Pārcelšanās uz Kuernavaku 
I957 Seminārs kopā ar Daisecu Sudzuki. Frīdas Frommas-Reihmanes nāve

1959 Mātes nāve, darbs „Zigmunda Freida misija”

I960 Politiska iesaistīšanās ASV Sociālistiskās partijas darbībā

196I Amerikāṇu iepaz̄̄stināšana ar agrīno Karlu Marksu - „Marksa koncepcija par cilvēku"

1962 Miera konference Maskavā. Starptautiskās psihoanalīzes sabiedrību federācijas un Starptautiskā psihoanalīzes foruma nodibināšana

1963 Meksikas Psihoanalīiskā institūta atklāšana

I964 Darbs „Cilvēka sirds”, biofilijas un nekrofilijas koncepta izstrāde

1967 Atteikšanās no amata pienākumiem Mehiko

I968 Iestāšanās par Eiženu Makkartiju vēlēšanās, infarkts, atteikšanās no politiskajām aktivitātēm. Darbs „Cerības revolūcija”

1969 Pirmā vasaras atpūta Tesīnā

I970 Pētījuma publicēšana par meksikāņu zemniekiem

I972 Iepazī̌šnās ar Raineru Funku, kurš kḷūst par viṇa zinātnisko sekretāru un autortiesỉbu pārvaldītāju

I973 Traktāts „Cilvēka destruktivitātes anatomija”

I974 Pārcelšanās uz Tesīnu

1976 Darbs „Piederēt vai būt?”

1977 Infarkts, garīgo spēku izsīkšana

I980 I8. martā Ērihs Fromms nomirst 



\section{Fromma darbu hronologiiskais saraksts}

Piln̄̄ga informācija par Ēriha Fromma darbiem gūstama viņa arhīvā:

Erich-Fromm-Arhiv

Usrainer Ring 24

D-72076 Tübingen

FAX (49 707I) 600049

(frommfunk@googlemail.com)

Sk. arī: http://www.fromm-gesellschaft.de; http://www.erich-fromm.de)

Par apkopojošāko izdevumu patlaban var uzskatīt:

Fromm E. Gesamtausgabe. München, 1999. Bd. I-I2. Hrsg. von R. Funk.

Pirmpublikāciju un tulkojumu apkopojumu sk.: Fromm E.

Gesamtausgabe. München, 1999. Bd. 10. S. 374-500.

Kopoto darbu (Gesamtausgabe) saturs (iekavās pirmpublikācijas gads; kvadrātiekavās - uzrakstī̌sanas gads):

BD. I.

Psychoanalyse un Soziologie (1929)

Der Staat als Erzieher. Zur Psychologie der Strafustiz (1930)

Zur Psychologie des Verbrechers und der strafenden Gesellschaft (193I)

Politik und Psychoanalyse (1931) 
Über Methode und Aufgabe einer Analytischen Sozialpsychologie (1932)

Die psychoanalytische Charakterologie und ihre Bedeutung für die Sozialpsychologie (1932)

Robert Briffaults Werk über das Mutterrecht (1933)

Die sozialpsychologische Bedeutung der Mutterrechtstheorie (1934)

Die Bedeutung der Mutterrechtstheorie für die Gegenwart (1970)

Die gesellsschatfliche Bedingtheit der psychoanalytischen Therapie (1935)

Studien über Autorität und Familie. Sozialpsychologischer Teil (1936)

Zum Gefühl der Ohnmacht (1937)

Über psychoanalytische Charakterkunde und ihre Anwendung zum

Verständnis der Kultur (1949)

Die Furcht vor der Freiheit (194I)

BD. 2.

Psychoanalyse und Ethik. Bausteine zu einer humanischen Charakterologie (1947)

Die Seele des Menschen. Ihre Fähigkeit zum Guten und zum Bösen (1964)

Haben oder Sein. Die seelischen Grundlagen einer neuen Gesellschaft (1976)

BD. 3.

Arbeiter und Angestellte am Vorabend des Drittes Reiches. Eine sozialpsychologische Untersuchung (1980)

Autorität und Familie. Geschichte und Methoden der Erhebungen (1936)

Psychoanalytische Charakterologie in Theorie und Praxis. Der

Gesellschafts-Charakter eines mexikanischen Dorfes (1970)

BD. 4 .

Wege aus einer kranken Gesellschaft (1955)

Die Revolution der Hoffnung. Für eine Humanisierung der Technik (1968) 
BD. 5 .

Fragen zum deutschen Charakter (1943)

Was soll mit Deutschland geschehen? (1943)

Marschiert Deutschland bereits wieder? (1966)

Den Vorrang hat der Mensch. Ein sozialistisches Manifest und Programm (1960)

Es geht um den Menschen! Eine Untersuchung der Tatsachen und

Fiktionen in der Aussenpolitik (196I)

Kommunismus und Koexistenz (196I)

Gründe für eine einseitige Abrüstung (1960)

Die Frage der Zivilverteidigung (1962)

Zur Theorie und Strategie des Friedens (1970)

Anmerkungen zur Entspannungspolitik (1975)

Der gegenwärtige Zustand des Menschen (1955)

Vorwort zu Edward Bellamy „Looking Backward” (1960)

Nachwort zu George Orwell „I984” (196I)

Propheten und Priester (1967)

Psychologische Aspekte zur Frage eines garantierten Einkommens für alle (1966)

Die psychologischen und geistigen Probleme des Überflusses (1970)

Die Zwiespältigkeit des Fortschritts. Zum ıoo. Geburtstag von Albert Schweitzer (1975)

Das Menschenbild bei Marx (196I)

Vorwort zu Karl Marx „Selected Writings” (1964)

Die Anwendung der humanistischen Psychoanalyse auf die marxistische Theorie (1965)

Probleme der Marx-Interpretation (1965)

Marx' Beitrag zum Wissen vom Menschen (1968) 
BD. 6.

Der Sabbat (1927)

Die Entwicklung des Christusdogmas. Eine psychoanalytische Studie zur sozialpsychologischen Funktion der Religion (1930)

Die prophetische Auffassung vom Frieden (1960)

Die Aktualität der prophetischen Schriften (1975)

Ihr werdet wie Gott. Eine radikale Interpretation des Alten Testaments und seiner Tradition (1966)

Psychoanalyse und Religion (1950)

Einige post-marxsche und post-freudsche Gedanken über Religion und Religiosität (1972)

Psychoanalyse und Zen-Buddhismus (1960)

Vorwort zu A. Reza Arasteh „Rumi the Persian” (1965)

Die Bedeutung des Ehrwürdigen Nyanaponika Mahathera für die westliche Welt (1976)

BD. 7.

Anatomie der menschlichen Destruktivität (1973)

BD. 8 .

Psychoanalyse als Wissenschaft (1955)

Der Mensch ist kein Ding (1957)

Psychoanalyse - Wissenschaft oder Linientreue? (1958)

Die Grundpositionen der Psychoanalyse (1966)

Die Krise der Psychoanalyse (1970)

Psychologie für Nichtpsychologen (1974)

Rezension zu W. Reich „Der Einbruch der Sexualmoral” (1933)

Die Sozialphilosophie der „Willenstherapie” Otto Ranks (1939)

Rezension zu M. Mead „Sex and Temperament in Three Primitive Societies" (1936) 
Rezension zu M. Mead „Cooperation and Competition Among Primitive Peoples” (1937)

Die Auswirkungen eine triebtheoretischen „Radikalismus” auf den Menschen. Eine Antwort auf Herbert Marcuse (1955)

Rezension zu C. G. Jung „Wirklichkeit der Seele” (1935)

C. G. Jung: Prophet des Unbewussten (1963)

Ödipus in Innsbruck (1930)

Einleitung zu P. Mullahy „Oedipus. Myth and Complex” (1948)

Der Ödipus-Komplex. Bemerkungen zum „Fall des kleinen Hans” (1966)

Sigmund Freud. Seine Persönlichkeit und seine Wirkung (1959)

Die philosophische Basis der Freudschen Psychoanalyse (1962)

Freuds Modell des Menschen und seine gesellschaftlichen Determinanten (1970)

Quellen menschlicher Destruktivität (1968)

Sigmund Freuds Psychoanalyse - Grösse und Grenzen (1979)

Geschlecht und Charakter (1943)

Sexualität und Charakter. Psychoanalytische Bemerkungen zum KinseyReport (1948)

Mann und Frau (195I)

BD. 9 .

Humanismus und Psychoanalyse (1963)

Einleitung zu E. Fromm „Socialist Humanism” (1965)

Zum Problem einer umfassenden philosophischen Anthropologie (1966)

Humanistische Planung (1970)

Jenseits der Illusionen. Die Bedeutung von Marx und Freud (1962)

Das Wesen der Träume (1949)

Märchen, Mythen, Träume. Eine Einführung in das Verständnis einer vergessenen Sprache (195I)

Der Traum ist die Sprache des universalen Menschen (1958) 
Die moralische Verantwortung des modernen Menschen (1958)

Psychologie und Werte (1959)

Der revolutionäre Charakter (1963)

Die Medizin und die ethische Frage des modernen Menschen (1963)

Der Ungehorsam als ein psychologisches und ethisches Problem (1963)

Einleitung zu E. Fromm un R. Xirau „The Nature of Man” (1968)

Der Wille zum Leben (1976)

Der kreative Mensch (1959)

Vorwort zu A.S. Neill „Summerhill” (1960)

Pro und Contra Summerhill (1970)

Psychologische Probleme des Alterns (1966)

Die Kunst des Liebens (1956)

BD. IO.

Jēdzienu un personu rādītājs

Bībeles, Marksa un Freida citātu rādītājs

Fromma rakstu koprādītājs

BD. II.

Das Jüdische Gesetz (1989 [1922])

Die Determiniertheit der psychischen Struktur durch die Gesellschaft.

Zur Methode und Aufgabe einer Analytischen Sozialpsychologie (1992 [1937])

Bachofens Entdeckung des Mutterrechts (1994 [1955])

Die männliche Schöpfung (1994 [1933])

Die Pathologie der Normalität des heutigen Menschen (I991 [1953])

„Dianetik” — Die Heilslehre der Scientology-Church (1950)

Der moderne Mensch und seine Zukunft (1992 [196I])

Die psychischen Folgen des Industrialismus (1992 [1964])

Die Überlebenschancen der westlichen Gesellschaft (1992 [1969]) 
Meine Kritik an der Industriegesellschaft (1992 [1964])

Überfluss und Überdruss in unserer Gesellschaft (1983 [1971])

Die Faszination der Gewalt und die Liebe zum Leben (1967)

Hitler - wer war er und was heisst Widerstand gegen diesen

Menschen? (1974)

Sind wir geistig noch gesund? (1965)

Der geistige Zustand Amerikas (1968 [1967])

Der politische Radikalismus in den Vereinigten Staaten und seine Kritik (1990 [1968])

Geistig gesundes Denken und Aussenpolitik (196I)

Anmerkungen zu einer realistischen Aussenpolitik (1990 [1961])

Russland, Deutschland, China - Bemerkungen zu Aussenpolitik (196I)

Chruschtschow und der kalte Krieg (1990 [196I])

Das neue kommunistische Programm (196I)

Die Herausforderung durch Castro (1990 [196I])

Die amerikanische Aussenpolitik nach der Kuba-Krise (1963)

Aussenpolitik nach dem Verbot von Atomwaffenversuchen (1964)

China und der Krieg in Vietnam (1965)

Die Globale Verantwortung der Vereinigten Staaten (1990 [1965])

Die Zukunft eines Neuen Europas (1990 [196I])

Tatsachen und Fiktionen über Berlin (196I)

Andere Stimmen aus Deutschland (1962)

Die Spiegelaffäre - ein altes Muster? (1990 [1962])

„Entspannung durch Stärke” (1964)

Die deutsche Frage (1990 [1965])

Alternativen zum Atomkrieg (1990 [196I])

Der Vietnamkrieg und die Brutalisierung des Menschen (1990 [1966])

Kennedys Mörder (1964)

Der Terrorismus von Baader und Meinhof (1977 [1976]) 
Märtirer und Helden (1990 [1967])

Für eine Kooperation von Israelis und Arabern (1990 [1948])

Citiziens for Reason (1990 [1955])

Warum ich für McCarthy bin (1990 [1968])

Humanistische Wissenschaft vom Menschen (1991 [1957])

Ein neuer Humanismus als Voraussetzung für die eine Welt (1992 [1962])

Auf der Suche nach der humanistischen Alternative (1992 [1968])

Die Idee einer Weltkonferenz (1992 [1966])

Wahlkampfrede für Eugene McCarthy beim „Versöhnungsbund” (1992 [1968])

Aufruf zum gemeinsamen Kampf gegen den Götzendienst (1992 [1975])

Credo eines Humanisten (1992 [1965])

Bemerkungen zu den Beziehungen zwischen Juden und Deutschen (1992 [1978])

Wer is der Mensch? (1983 [1979])

Im Namen des Lebens. Ein Porträt im Gespräch mit Hans Jürgen Schultz (1974)

BD. I2.

Über meinen psychoanalytischen Ansatz (1990 [1969])

Die dialektische Revision der Psychoanalyse (1990 [1969])

Sexualität und sexuelle Perversionen (1990 [1969])

Der angebliche Radikalismus von Herbert Marcuse (1990 [1969])

Wandel im Verständnis der Homosexualität (1994 [1940])

Individuelle und gesellschaftliche Ursprünge der Neurose (1944)

Psychische Bedürfnisse und Gesellschaft (1992 [1956])

Der Einfluss gesellschaftlicher Faktoren auf die Entwicklung des Kindes (1958)

Zum Verständnis von seelischer Gesundheit (1991 [1962])

Ist der Mensch von Natur aus faul? (1991 [1974]) 
Anmerkungen zum Problem der Freien Assoziation (1955)

Das Unbewusste und die psychoanalytische Praxis (1992 [1959])

Wirkfaktoren der psychoanalytischen Behandlung (1991 [1964])

Therapeutische Aspekte der Psychoanalyse (199I [1974])

Die Bedeutung der Psychoanalyse für die Zukunft (1992 [1975])

Vom Haben zum Sein. Wege und Irrwege der Selbsterfahrung ( 1989

[1974/1975])

Meister Eckhart und Karl Marx: Die reale Utopie der Orientierung am Sein (1992 [1974])

Fromma audiotekstus ir izdevis Rainers Funks:

Erich Fromm Audio-CD, 2012 (I-19)

Fromma nepublicētie darbi un vēstules bez jau minētā Fromma arhīva Tībengenē rodami:

New York Public Library

Instituto Mexicano de psicoanàlisis. C. de Odontologia 9,

Col. Copilco Universidad, Deleg. Coyoacán,

04360-Mexico D.F.. FAX (525) 6593524 



\section{Erich Fromm and Latvia}

\section{Summary}

The name of Erich Fromm was mentioned for the first time in Latvian public discourse in 193I. It is possible that he was not completely unknown in Latvia during the thirties. Besides, Fromm's presence in Latvia need not be directly textual, general dissemination of his views may be in order. As from the end of the thirties, a period of deep silence about Fromm's views sets in, This situation was only partly overcome at the end of the seventies. The change took place in a very tentative manner, and his voice is not fully audible yet.

The origins of the present collective monograph go back to the year of 2013, when an international conference „Freedom; Opportunities and Threats" was held in Riga in cooperation with the International Society of Erich Fromm, and was greatly facilitated by the contribution of the former Secretary of E. Fromm and the holder of his copyright Rainer Funk. Psychoanalysts, philosophers and psychologists from Germany, Mexico and Latvia were involved. The conference was patronized by Ex-President of Latvia Vaira Vike-Freiberga, who shared her experience in connection with Fromm. Thus, the idea about a collective monograph came to fruition, 
concentrating attention on Fromm within the context of psychoanalysis and phenomenology.

The collective monograph consists of five parts. The first part deals with Fromm's life and ideas. In the second one Fromm is viewd in the context of Latvia, while the third one concentrates attention on the psychoanalyses and philosophy of Fromm. The fourth part consists of a translation - so far the most extensive one - of Fromm's text „Escape from Freedom”. The fifth part contains a short life-course description of Fromm and a list of his publications.

Helmut Johach presents the biography of Fromm in the history-of-ideas manner.He writes about Fromm's family, the education he obtained, his Jewish background. Fromm was born in an Orthodox Jewish family, yet later in his life he took an interest in the Hasidic an Prophetic traditions. Fromm's life in USA and in Mexico is also described, so is his seniority period, spent $n$ Switzerland. Raina Funk develops the ideas of Fromm with special reference to the topicality of his work „Escape from Freedom” (1914). Funk touches briefly on the problematics of freedom in Western society and discusses in detail the role of freedom in Fromm's psychology. Funk stresses that Fromm was the first psychologist to undertake the analysis of the problematic of freedom with regard to modern people. He dwells, in particular, on the present-day challenges of freedom; he speaks of freedom as emancipation, Ertgrenzung, as a characteristic feature of the modern Self-orientated society. Funk concludedes his deliberations by pointing out the unlimited freedom and fear of reality.

Maija Kūle writes about freedom in present-day Latvia in the light of Fromm's analytical social psychology; she touche on some of the latest cases of socio-political events. Küle demonstrates both the similarities and the differences of the spiritual, intellectual approach of Fromm and the stance of the Latvian intellectuals. She discusses, in particular, the religious awakening in Latvia and writes about some of the personalities within the context of the freedom of Latvia. Küle is also deliberating about the verbalisation of the thoughts about freedom and the language-use as a strategy for survival. Solveiga Krūminn-Kon,kova tackles a comparatively non-researched theme - namely, the comparison of Fromm and Steiner within the context of Latvian intellectual life. She notes that both thinkers were concerned 
with freedom. Basing her researh on archival sources, as she does, KrūmiñaKonkova discusses the ways and means whereby Steiner has made an impact on the Latvian spiritual ethos.

Igors Šuvajevs dicusses the viability of Fromm's teaching in Latvia. He distinguishes between such phenomena as freedom, freedoms and liberation. Šuvajevs speaks about persistent presence of some of the features desribed by Fromm, existing in Latvia. These being such devices as periodical flight from freedom, and formation of ever-new escapades. Šuvajevs discusses some elements of respective discursive practises and their manifestations. In the end of the article Šuvajevs discusses the art living or the art of being as discernable in Fromm.

Ieva Stūre-Stūriņa discusses such notions as flight and the death-wish with special reference to sadomasochism and destructiveness. She compares Fromm's contribution with that of Freud's, concerning the relevant contacts between the two teachings and marking the existing differences. Anne Sauka dicusses Froms's notions of "to be" and "to have" within the context of the ethics of Selfhood. She draws attention to an inner contradiction within Fromm's humanism, and proposes a new kind of interpretation of his views by way of accentuating of the phenomenology of the body. Her radicalized interpretation involves nihilistic reading of Fromm's views and accentuates some of the aspects of the selfhood of the body (the actual presence of the body, the illusory charcter of the body,the intrinsic ethicality of the body). At the very end Fromm's uses of the body are dicussed in the Art-of-Life context.At the same time Anne Sauka dicusses Fromm in connection with Nietzsche. Notion of the estrangement of the human being within the socially determind network, as opposed to Dionysian state, is also touched upon. Sauka discusses both the common lines of thought of Fromm and Nietzsce, as well as marks the differences between the two.

Māris Kūlis discusses the problematics of truth. He turns special attention to the Latvian thinkers Pauls Dāle and Konstantīns Raudive applying to them the concept of optimal truth, which reminds of pragmatic approach. M. Külis holds that Fromm's most essential contribution towards that end is concerned with the person's role in truth-formation, and is revealed in the solution of every-day problems. Anda Kande is discussing Fromm's ideas within the context of the Stoa notion of art-of-life philosophy. She 
stresses, in particular, the problematics of determinism and the possibility of freedom. Kande's solution takes the form of art-of-life philosophy approach, by concentrating on such notions as choice, will, and self-power. She accentuates the strategy of self-redeeming, characteristic of the Stoa philosophy, by identifieing in Fromm such features as love, including selflove. Edijs Šauers attempts to amalgamate the teachings of Fromm and Kant by way of accentuating of the problematics of freedom and love; he discusses some of the differences between the two thinkers and deals wih some common features of both. Šauers discusses such themes as objectivity of another person, emancipation from Narcissism, rational belief, self-knowledge and emotional attitude towards the self.

The collective monograph is concluded with a translation into Latvian of part of Fromm's work „Escape from Freedom”, as well as a short list of the data of Fromm's life-course and his bibliography. Thus, the topicality of Fromm's teaching in Latvia may be said to be established, though the translation of his works is only in a nascent stage. The translation of psychoanalytical texts is not just a mechanical repetition of some words and phrases. Every translation rquires relevant terminological, conceptual efforts. Understanding of such a text confronts us with new problems, that have remained obscure when reading the original vesion. Therefore translsation of Fromm's works enhances the topicality of his thought and fosters the interpretative efforts within the Latvian culture.

E. Fromm is a many-sided, versatile thinker, whose ideas are pertinent for the formation of modern life-style in general. Yet, one of the aspects deserve special accentuation - that of the art of living, or the art of being. This concept goes to reveal the trans-therapeutical significance of Fomm's psycoanalyses. Already in his early work „Man for Himself” (1947) Fromm postulates the idea of ethics as an art-of-life, whereby a person is both an artist and an artefact of his/her own life course. This has to do with the formation of self-being and self- sustaning. It is this field where the views of Fromm's are still very topical, indeed. 

Izdevējs: LU aǵentūra „LU Filozofijas un sociologijas institūts”

Kalpaka bulvāris 4, Rīga, LV-1940

tālr. -67034520 e-pasts - fsi@lza.lv

fakss - 67210806 www.fsi.lv

Izdevējdarbības reg̣istrācijas apliecība: Nr. 2-0521

Iespiests SIA „Vītola izdevniecība”, Gulbenē 


\section{Bēgšana no brīvības? Erihs Fromms un Latvija}

Dr. phil. profesora Igora Šuvajeva zinātniskajā redakcijā

Tomēr tiesībām paust savas domas ir nozìme vien tad, ja esam spējīgi domāt paši; brīvība no ārējas autoritātes ir ilgstošs ieguvums vien tad, ja mūsu iekšējie psiholoğiskie apstākḷi paver iespēju apliecināt savu individualitāti.

Ērihs Fromms, Bēgšana no brivibas 